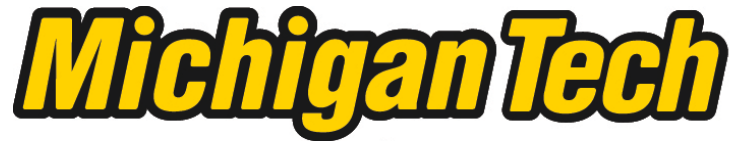 \\ Michigan Technological University Create the Future Digital Commons @ Michigan Tech
}

2014

\section{IMPACTS OF CLIMATE CHANGE ON SOIL MICROORGANISMS IN NORTHERN HARDWOOD FORESTS}

Carley Jane Kratz

Michigan Technological University

Follow this and additional works at: https://digitalcommons.mtu.edu/etds

Part of the Ecology and Evolutionary Biology Commons, Environmental Sciences Commons, and the Microbiology Commons

Copyright 2014 Carley Jane Kratz

\section{Recommended Citation}

Kratz, Carley Jane, "IMPACTS OF CLIMATE CHANGE ON SOIL MICROORGANISMS IN NORTHERN HARDWOOD FORESTS", Dissertation, Michigan Technological University, 2014.

https://doi.org/10.37099/mtu.dc.etds/755

Follow this and additional works at: https://digitalcommons.mtu.edu/etds

Part of the Ecology and Evolutionary Biology Commons, Environmental Sciences Commons, and the Microbiology Commons 


\section{IMPACTS OF CLIMATE CHANGE ON SOIL MICROORGANISMS IN NORTHERN HARDWOOD FORESTS}

\section{By}

Carley Jane Kratz

\section{A DISSERTATION}

Submitted in partial fulfillment of the requirements for the degree of DOCTOR OF PHILOSOPHY

In Forest Science

MICHIGAN TECHNOLOGICAL UNIVERSITY

2014 
This dissertation has been approved in partial fulfillment of the requirements for the Degree of DOCTOR OF PHILOSOPHY in Forest Science.

School of Forest Resources and Environmental Science

Dissertation Co-Advisor: Andrew J. Burton

Dissertation Co-Advisor: Erik A. Lilleskov

Committee Member: Amy Marcarelli

Committee Member: Paul Doskey

School Dean: Terry Sharik 


\section{Table of Contents}

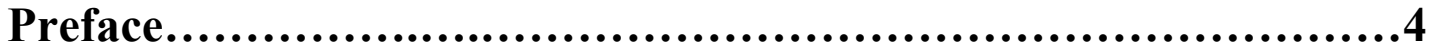

Abstract....................................................................5

Chapter 1...........................................................

Chapter 2 ..............................................................15

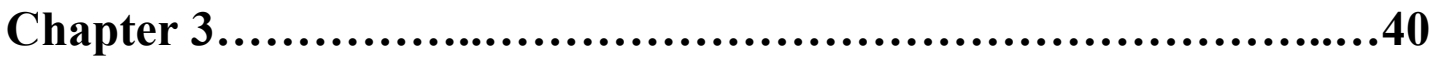

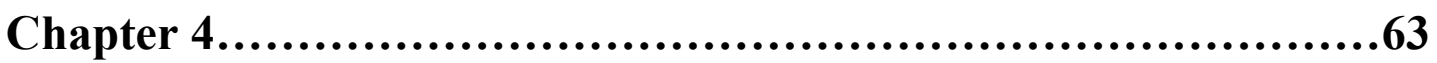

Chapter 5............................................................107

Chapter 6.......................................................161

Chapter 7 .............................................................204 


\section{Preface}

Chapter 2 has been formatted for submission to Global Change Biology. It is currently under revision and pending submission. The order of authors for this article will be; Carley Kratz, Andrew Burton, Erik Lilleskov and Jerry Mellilo. Carley Kratz, Andrew Burton and Erik Lilleskov have all contributed to the written portion of the text. Jerry Mellilo oversees the experiments. Carley Kratz, Andrew Burton and Erik Lilleskov contributed to the methodological design. Data was collected and processed by Carley Kratz.

Chapter 3 has been formatted for submission to Global Change Biology. It is currently under revision. The order of authors for this article will be Carley Kratz, Erik Lilleskov and Andrew Burton. Carley Kratz, Andrew Burton and Erik Lilleskov have all contributed to the written portion of the text. Andrew Burton oversaw the experimental site. Carley Kratz, Andrew Burton and Erik Lilleskov contributed to the methodological design. Data was collected and processed by Carley Kratz.

Chapters $4 \& 5$ will be merged into a single article for publication in the journal Soil Biology and Biochemistry. Data from Chapter 6 will be used in this publication. The figures and text will be reformatted before submission. The order of authors for this article will be Carley Kratz, Erik Lilleskov and Andrew Burton. Carley Kratz, Andrew Burton and Erik Lilleskov have all contributed to the written portion of the text. Andrew Burton oversaw the experimental site. Carley Kratz contributed to the methodological design and was responsible for collecting and processing data.

All chapters will be reformatted before submission to journals, and journals selected have a fair use policy for publishing materials from copyrighted dissertations. 


\section{Abstract}

As global climate continues to change, it becomes more important to understand possible feedbacks from soils to the climate system. This dissertation focuses on soil microbial community responses to climate change factors in northern hardwood forests. Two soil warming experiments at Harvard Forest in Massachusetts, and a climate change manipulation experiment with both elevated temperature and increased moisture inputs in Michigan were sampled. The hyphal in-growth bag method was to understand how soil fungal biomass and respiration respond to climate change factors. Our results from phospholipid fatty acid (PLFA) analyses suggest that the hyphal in-growth bag method allows relatively pure samples of fungal hyphae to be partitioned from bacteria in the soil. The contribution of fungal hyphal respiration to soil respiration was examined in climate change manipulation experiments in Massachusetts and Michigan. The Harvard Forest soil warming experiments in Massachusetts are long-term studies with 8 and 18 years of $+5{ }^{\circ} \mathrm{C}$ warming treatment. Hyphal respiration and biomass production tended to decrease with soil warming at Harvard Forest. This suggests that fungal hyphae adjust to higher temperatures by decreasing the amount of carbon respired and the amount of carbon stored in biomass. The Ford Forestry Center experiment in Michigan has a 2 x 2 fully factorial design with warming $\left(+4-5{ }^{\circ} \mathrm{C}\right)$ and moisture addition ( $+30 \%$ average ambient growing season precipitation). This experiment was used to examine hyphal growth and respiration of arbuscular mycorrhizal fungi (AMF), soil enzymatic capacity, microbial biomass and microbial community structure in the soil over two years of experimental treatment. Results from the hyphal in-growth bag study indicate that AMF hyphal growth and respiration respond negatively to drought. Soil enzyme activities tend to be higher in heated versus unheated soils. There were significant temporal variations in enzyme activity and microbial biomass estimates. When microbial biomass was estimated using chloroform fumigation extractions there were no differences between experimental treatments and the control. When PLFA analyses were used to estimate microbial 
biomass we found that biomass responds negatively to higher temperatures and positively to moisture addition. This pattern was present for both bacteria and fungi. More information on the quality and composition of the organic matter and nutrients in soils from climate change manipulation experiments will allow us to gain a more thorough understanding of the mechanisms driving the patterns reported here. The information presented here will improve current soil carbon and nitrogen cycling models. 


\section{Chapter 1: Introduction}

This dissertation examines the impact of climate change factors on soil microbial communities from manipulation experiments in two different locations. The first set of experiments is located in Petersham, Massachusetts at Harvard Forest $\left(42^{\circ} 20^{\prime} \mathrm{N}, 72^{\circ} 10^{\prime} \mathrm{W}\right)$. Mean temperature varies from $-6^{\circ} \mathrm{C}$ in January to $20^{\circ} \mathrm{C}$ in July. Mean annual precipitation is approximately $108 \mathrm{~cm}$. Both experimental locations are even-aged mixed deciduous forests dominated by red maple (Acer rubrum L.), striped maple (Acer pensylvanicum L.) and black oak (Quercus velutina L.). The overstory species composition varies slightly between the two experiments. There is more sweet birch (Betula lenta L.) present at Prospect Hill than Barre Woods. Soils are fine loam of the Gloucester series (fine loamy, mixed, mesic Typic Dystrochrept). Agricultural practices ended here in the early 1900's, at which point an old-field forest was established (Peterjohn et al. 1994). Both experiments at Harvard Forest use heating cables buried at $9 \mathrm{~cm}$ depth to warm the soil to $5^{\circ} \mathrm{C}$ above ambient soil temperatures. The Prospect Hill experiment was active for 18 years and the Barre Woods experiment was active for 8 years when hyphal growth and respiration were measured. Experimental plots at Prospect Hill are $6 \mathrm{~m}$ x $6 \mathrm{~m}$. At Prospect Hill all 6 control plots and 6 heated plots were sampled. There are two mega-plots at Barre Woods, divided into smaller subplots. Each mega-plot at Barre Woods is $30 \mathrm{~m}$ x $30 \mathrm{~m}$. Six subplots from each mega-plot were sampled at Barre Woods.

The second experiment is located at Michigan Technological University's Ford Forestry Center ( $46^{\circ} 38^{\prime} 26^{\prime \prime} \mathrm{N} 88^{\circ} 29^{\prime} 01^{\prime \prime} \mathrm{W}, 400 \mathrm{~m}$ elevation). Mean annual temperature in the area is $4.9^{\circ} \mathrm{C}$, with a growing season (May through September) average temperature of $15^{\circ} \mathrm{C}$. The area receives on average $879 \mathrm{~mm}$ of precipitation annually, with $401 \mathrm{~mm}$ of precipitation falling during the growing season (Burton et al. 2012). Sugar maple (Acer saccharum Marsh.) dominates the overstory (trees $>5.0 \mathrm{~cm}$ diameter), contributing to $89 \%$ of the overstory basal area. American elm (Ulmus americana L.), eastern hemlock (Tsuga canadensis (L.) Carr.), ironwood 
(Ostrya virginiana (Mill.) K. Koch) and yellow birch (Betula alleghaniensis Britton) comprise the remainder. Soils are Kallio cobbly silt loams (Coarse-loamy, mixed, superactive, frigid Oxyaquic Fragiorthods). This hardwood forest has been managed for sugar maple production and has not been thinned for over a decade.

The Ford Forestry Center experiment has a 2 × 2 fully factorial randomized block design with warming $\left(+4-5{ }^{\circ} \mathrm{C}\right)$ and moisture addition $(+30 \%$ average ambient growing season precipitation). Heating was achieved using infrared lamps suspended $1.5 \mathrm{~m}$ above the soil surface. There are twelve $10 \mathrm{~m} \times 10 \mathrm{~m}$ plots in three blocks. Each block contains four plots, one from each experimental treatment. The moisture addition represents the upper limit of potential precipitation predicted by IPCC models (Christensen et al. 2007), and in most years should replace any evaporative loss associated with the elevated temperature treatment. Precipitation was harvested from a rooftop catchment of a nearby building, stored in large holding tanks, and distributed approximately weekly onto plots using a sprinkler system. Moisture addition occurred during rain events when possible, in order to mimic natural patterns of precipitation. Treatments were applied during the growing season from April 22, 2011 to October 11, 2011 and from March 25, 2012 to October 24, 2012. Figure 1.1 shows the mean temperature $\left({ }^{\circ} \mathrm{C}\right)$ for each treatment in 2011 (reproduced from data published in Jarvi and Burton 2013). Figure 1.2 shows the mean temperature for each treatment $\left({ }^{\circ} \mathrm{C}\right)$ in 2012 . It is important to note that there was a drought in the summer of 2011. During August and September of 2011 the soil was visibly dry. Figure 1.3 shows the mean volumetric soil moisture content for each treatment in 2011, demonstrating the impact of the drought on soil moisture (reproduced from data published in Jarvi and Burton 2013). Figure 1.4 shows the mean volumetric soil moisture content for each treatment in 2012.

This study attempted to understand how climate change factors impact the microbial community by examining changes in hyphal biomass production and respiration, soil enzymatic activity, microbial biomass and the structure of the microbial community. Chapter 2, "Decreased Growth and Respiration of Fungal Hyphae Following Long-Term Soil Warming”, focuses on hyphal biomass 
production and respiration in soils from the Harvard Forest soil warming experiments. Chapter 3, "Growth and Respiration of Arbuscular Mycorrhizal Fungal Hyphae are Negatively Impacted by Elevated Soil Temperature and Drought”, examines the impact of soil warming and moisture addition at the Ford Forestry Center on the hyphal biomass production and respiration of arbuscular mycorrhizal fungi in particular. Understanding the ways in which fungal hyphae respond to soil warming and changes in moisture inputs may enhance soil carbon and nutrient cycling models, since fungi have the ability to break down complex organic polymers (Kellner et al. 2010) and function as mycorrhizal symbionts (Smith and Read 2008). Chapter 4, "Climate Change Study on Soil Extracellular Enzyme Activity Responds More Strongly to Drought than Soil Warming”, presents results of potential soil enzyme activity assays at the Ford Forestry Center from 2011. Chapter 5 "Microbial Biomass and Extracellular Enzyme Activities Show Seasonal Variability in an Experimental Climate Change Manipulation in a Temperate Hardwood Forest", discusses results of potential soil enzyme activity assays at the Ford Forestry Center in 2012. The potential for enzymes in the soil to break down various polymers may also be altered by climate change, and soil enzyme assays performed here give us more insight into the ultimate fate of both organic and inorganic compounds, some of which are considered labile and some of which are more recalcitrant. Chapter 6 "Soil Microbial Abundance Shows a Negative Response to Elevated Temperature and a Positive Response to Increased Moisture", utilizes phospholipid fatty acid analysis to determine how the relative abundance of bacteria and fungi in the soil respond to elevated temperature and moisture inputs. Understanding how the structure of the soil microbial community changes when temperature is elevated and moisture inputs are altered allows us to discern the future role that groups of microorganisms will have as the climate continues to change. The relative abundance of soil fungi, for example, may be particularly important for soil carbon sequestration because fungi produce a large amount of oxidative enzymes that break down recalcitrant soil compounds, such as lignin (Kellner et al. 2010). 


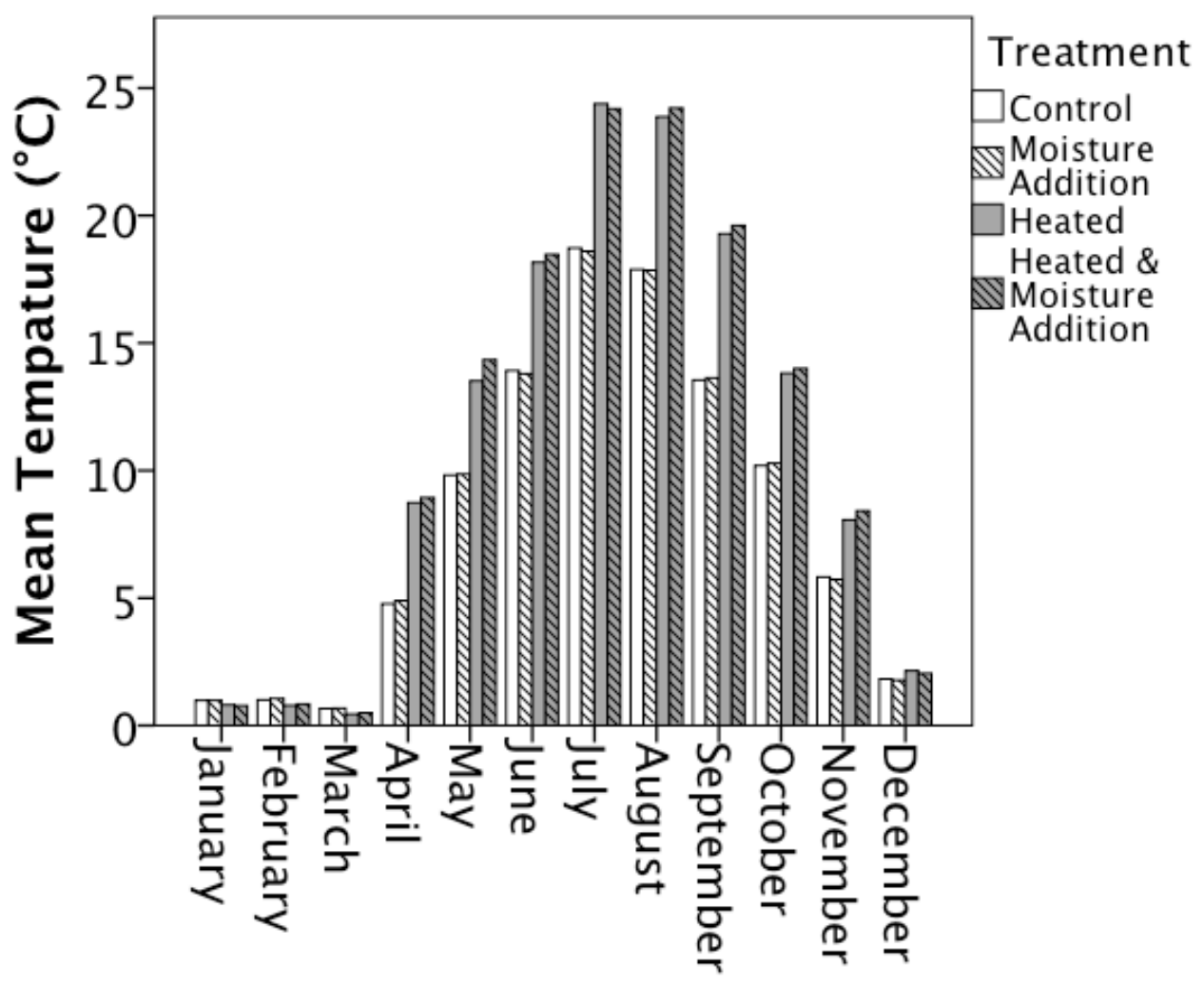

Month

Figure 1.1 Mean monthly soil temperatures for each treatment at the Ford Forestry Center in 2011. Values are the average of 5 sensors located at depths from 2 to 10 $\mathrm{cm}$ depth in each plot. The mean annual soil temperature was approximately $11^{\circ} \mathrm{C}$ for heated plots and approximately $8{ }^{\circ} \mathrm{C}$ for unheated plots. 


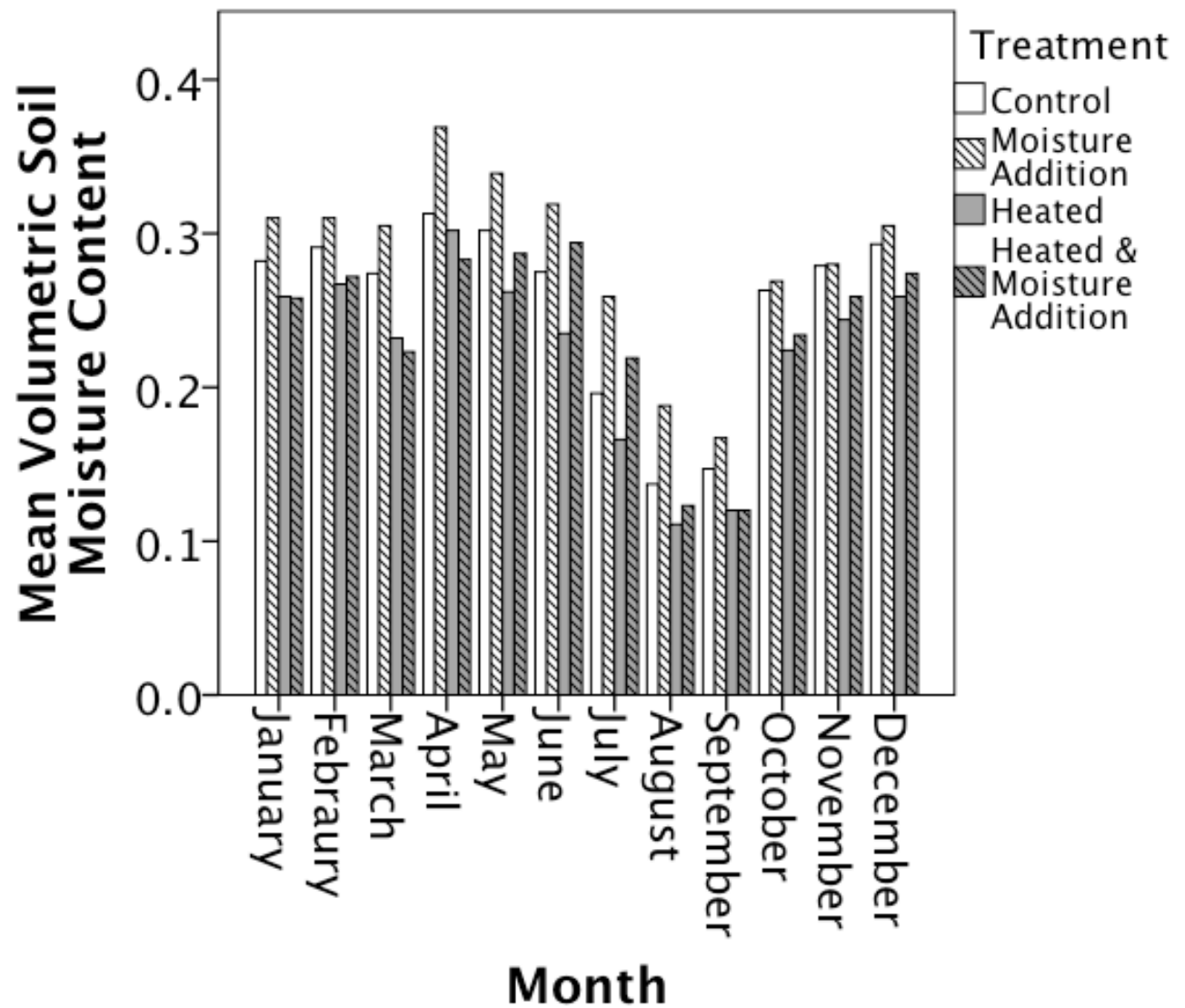

Figure 1.2 Mean monthly volumetric soil moisture content for each treatment at the Ford Forestry Center in 2011. Values are the average of 5 sensors located at depths from 2 to $10 \mathrm{~cm}$ depth in each plot. The mean annual soil moisture content was approximately $0.275 \mathrm{~m}^{3} / \mathrm{m}^{3}$ for unheated plots and $0.225 \mathrm{~m}^{3} / \mathrm{m}^{3}$ for heated plots. 


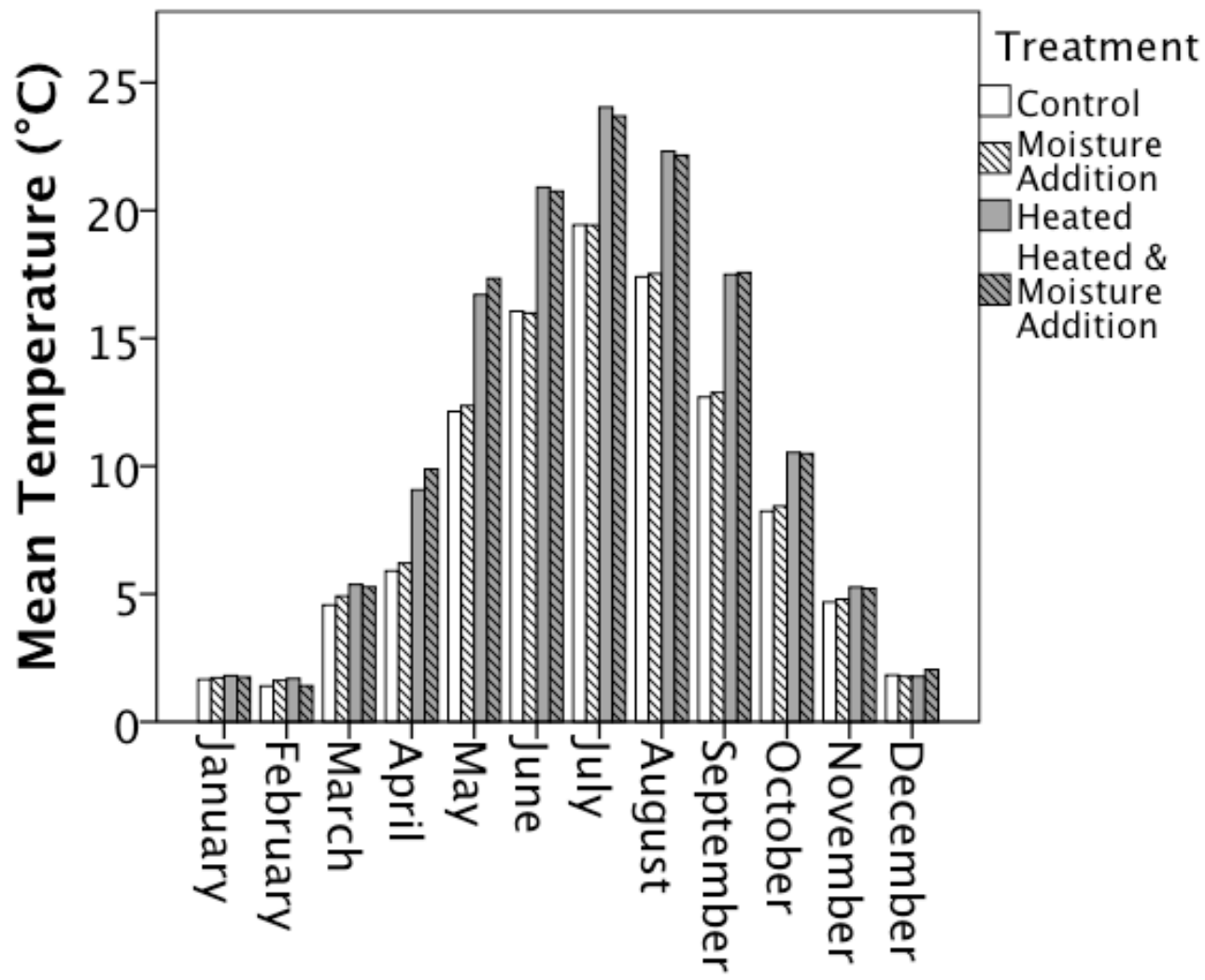

Month

Figure 1.3 Mean monthly temperatures for each treatment at the Ford Forestry Center in 2012. Values are the average of 5 sensors located at depths from 2 to 10 $\mathrm{cm}$ depth in each plot. The mean annual soil temperature was approximately $11.5^{\circ} \mathrm{C}$ for heated plots and approximately $9^{\circ} \mathrm{C}$ for unheated plots. 


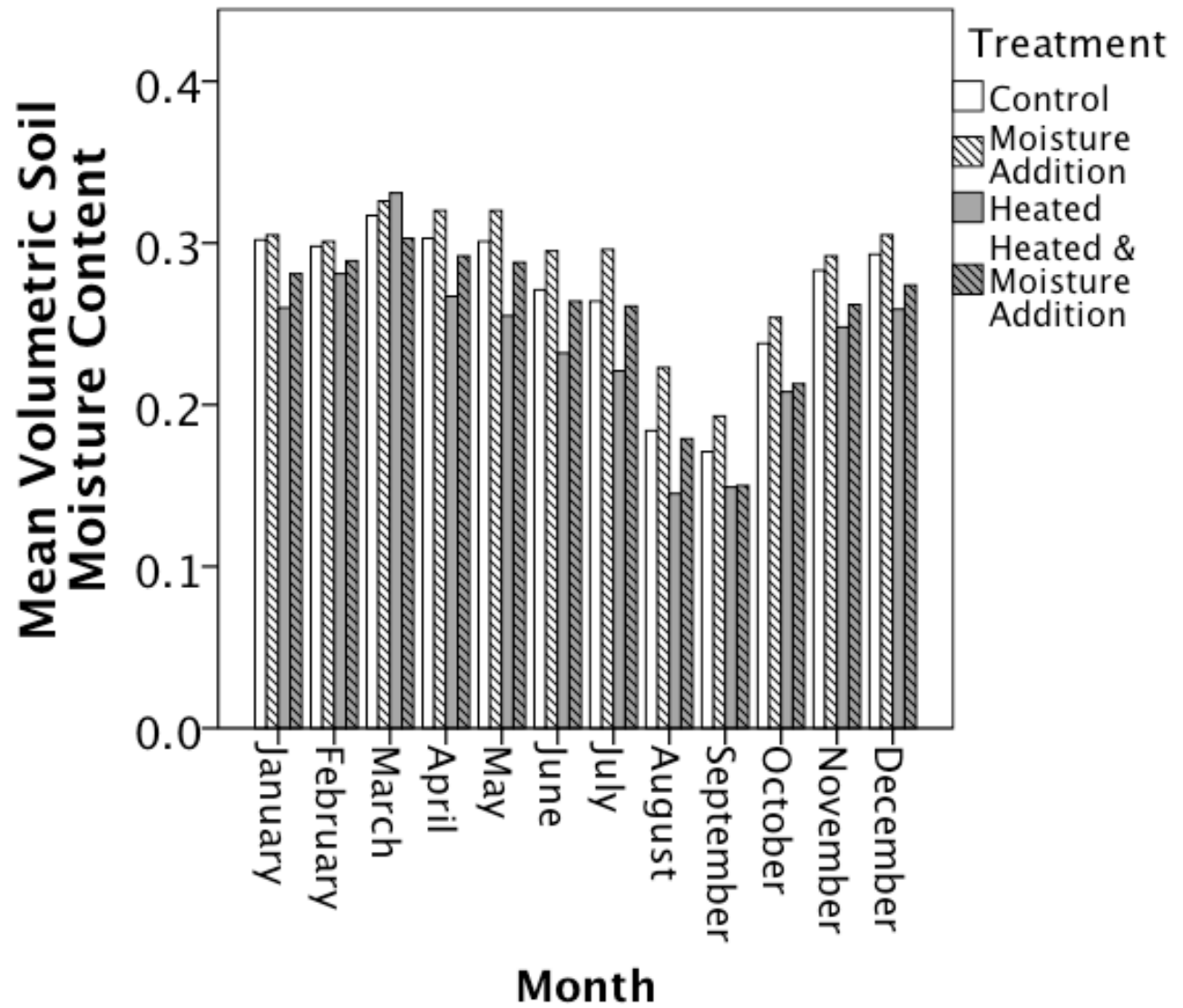

Figure 1.4 Mean monthly volumetric soil moisture content for each treatment at the Ford Forestry Center in 2012. Values are the average of 5 sensors located at depths from 2 to $10 \mathrm{~cm}$ depth in each plot. The mean annual soil moisture content was approximately $0.275 \mathrm{~m}^{3} / \mathrm{m}^{3}$ for unheated plots and $0.240 \mathrm{~m}^{3} / \mathrm{m}^{3}$ for heated plots. 


\section{References}

Burton, A.J., Jarvey, J.C., Jarvi, M.P., Zak, D.R., and K.S. Pregitzer. 2012. Chronic $\mathrm{N}$ alters root respiration-tissue $\mathrm{N}$ relationship in northern hardwood forests. Global Change Biology. 18: 258-266.

Christensen, J. H., Hewitson, B., Busuioc, A. et al. In: Climate Change 2007: The Physical Science Basis. Contribution of Working Group I to the Fourth Assessment Report of the Intergovernmental Panel on Climate Change. Solomon, S. et al. (eds.). Cambridge University Press: New York, New York, USA.

Jarvi, M.P. and A.J. Burton. 2013. Acclimation and soil moisture constrain sugar maple root respiration in experimentally warmed soil. Tree Physiology. 33: 949959.

Kellner, H., Vandenbol, M. and D. Zak. 2010. Fungi unearthed: Transcripts encoding lignocellulolytic and chitinolytic enzymes in forest soils. PLOS ONE. 5(6): e10971. doi:10.1371/journal.pone.0010971

Peterjohn, T., Melillo, J.M., P.A. Steudler, Newkirk, K.M, Bowles, F.P. and J.D. Aber. 1994. Responses of trace gas fluxes and $\mathrm{N}$ availability to experimentally elevated soil temperatures. Ecological Applications. 4: 617:625.

Smith, S.E. and D.J. Read. 2008. Mycorrhial Symbiosis, Third Edition. Academic press, Elsevier. London, UK. 


\section{Chapter 2: Decreased Growth and Respiration of Fungal Hyphae Following Long-Term Soil Warming ${ }^{1}$}

\subsection{Abstract}

Little is known about how mycorrhizal fungi respond to soil warming, however changes in the growth or respiration of mycorrhizal fungi may have a large impact on plant growth and soil carbon cycling. This study sampled mycorrhizal fungal hyphae at both the Prospect Hill and Barre Woods Long-Term Ecological Research warming experiments at Harvard Forest during the 2011 field season. The hyphal in-growth bag method was used to isolate fungal hyphal tissue from other organisms in the soil. Both hyphal biomass and respiration measurements were taken. Hyphal in-growth bags were placed below the soil surface and incubated for 2 months from July to September, and then analyzed for biomass and respiration. Biomass-specific respiration was approximately $50 \%$ lower in heated plots compared to control plots at both sites, although this difference was only statically significant at the Barre Woods site $(P=0.003)$. Fungal hyphal biomass was approximately $30 \%$ lower in the heated versus unheated plots Barre Woods $(P=0.324)$, although not statistically significant. We also found that elevated temperature had a negative impact on hyphal respiration and higher moisture content had a positive impact on hyphal respiration. These results suggest that, in general, hyphal biomass production and respiration decrease under long-term soil warming. The mechanisms behind the reduction in biomass-specific respiration in response to soil warming remain unclear. It is possible that the respiration of fungi growing in heated treatments has decreased in response to lower soil moisture availability due to a metabolic homeostasis response. It is also possible that the availability of other resources, including carbon

\footnotetext{
${ }^{1}$ Chapter 2 has been formatted for submission to Global Change Biology. It is currently under revision and pending submission. The order of authors for this article will be; Carley Kratz, Andrew Burton, Erik Lilleskov and Jerry Mellilo. Carley Kratz, Andrew Burton and Erik Lilleskov have all contributed to the written portion of the text. Jerry Mellilo oversees the experiments. Carley Kratz, Andrew Burton and Erik Lilleskov contributed to the methodological design. Data was collected and processed by Carley Kratz.
} 
supply from mycorrhizal trees, may limit the growth and respiration of fungal hyphae in the warmed plots, but not in the control plots. Soil respiration at these sites was initially high following the initiation of the warming experiments, however it decreased over time to rates similar to those before warming began. Our results indicate that soil fungal hyphae likely play a role in this apparent acclimation of soil respiration to long-term warming.

\subsection{Introduction}

Increasing global temperatures have been linked to increased concentrations of greenhouse gases in the atmosphere. These gases, including carbon dioxide $\left(\mathrm{CO}_{2}\right)$, increase radiative forcing which causes warming of the earth's surface (Christensen et al. 2007, Meehl et al. 2007). Soil respiration, a major component of the flux of $\mathrm{CO}_{2}$ from the soil, is the world's second largest terrestrial carbon flux, and it has been increasing over the past half century (Bond-Lambert and Thomson 2010). Temperature is often the most important variable when modeling soil respiration (Raich and Potter 1995), yet it remains unclear how soil respiration will respond to warming global temperatures in the long-term. Some studies indicate that soil respiration is positively correlated with increasing temperature (Reth et al. 2009). This has the potential to cause a positive feedback in which higher temperatures cause elevated metabolic rates, which increases soil $\mathrm{CO}_{2}$ flux to the atmosphere, leading to further warming (Mellilo et al. 2002). Most studies have shown that soil respiration adjusts to temperature over time (Oechel et al. 2000, Luo et al. 2001, Bradford et al. 2008). Although there are initial increases in soil respiration rates, after a few years of warming, soil respiration rates decrease to a basal level, similar to the soil respiration rates before warming began. The warminginduced positive feedback of carbon dioxide to the atmosphere may therefore be mitigated by an apparent acclimation of soil respiration.

An apparent acclimation of respiration will occur if a resource or condition other than temperature limits metabolic rates, or if homeostasis occurs (Atkin and Tjoelker 2003). True acclimation is driven by the homeostatic regulation of metabolic rates of soil dwelling organisms to reach an energetically optimal level of 
respiration. An apparent acclimation may be driven by many other mechanisms, including those involved in true acclimation. It is possible that nutrients or resources limit growth and respiration in warmed versus control plots. For instance, decreases in available labile nutrients or carbon sources may occur with long-term soil warming. Decreases in available soil moisture may also limit growth and respiration in warmed versus control plots.

Soil fungi make up a large proportion of the microbial biomass in the upper layers of forest soils, yet the contribution of soil fungi to total soil respiration remains unclear. Fungi play important roles in soil carbon degradation and nutrient acquisition for other soil organisms. Fungi produce the majority of enzymes that break down complex organic substrates such as lignin and chitin (Kellner et al. 2010). In addition to making nutrients available via decomposition, fungi provide nitrogen and phosphorus resources directly to plants in exchange for photosynthate in mycorrhizae (Smith and Read 2008). The physiological responses that fungal hyphae exhibit when experimentally warmed have not been directly studied in the field. It has been demonstrated that fungi grown in culture or in mesocosms respire more rapidly when exposed to higher temperatures or light conditions in the shortterm (Bååth and Wallander 2003, Heinemeyer et al. 2006, Koch et al. 2007, Atkin et al. 2008, Hawkes et al 2008, Malcolm et al. 2008). Sporocarps in the field exhibit a similar response (Andrew et al. in press), however it remains unknown how belowground fungal hyphae change in response to warming, particularly in the longterm.

Studying the contribution of soil fungi to soil respiration is logistically challenging, as the fungal tissue must be isolated from other sources of respiration in the soil. This challenge is enhanced in the case of mycorrhizal fungi because the fungal tissue must be separated from that of the host plant. An attempt at overcoming this challenge has been made using nylon mesh with small pores to exclude plant roots but not fungal hyphae, often accompanied by an organic-poor substrate to exclude the growth of free living heterotrophs (Wallander et al. 2001, Van Diepen 2008, Moyano et al. 2008). It has been shown that the hyphal in-growth 
bag environment is able to support the growth of both ectomycorrhizal fungi (EMF) (Wallander et al. 2001) and arbuscular mycorrhizal fungi (AMF) (Van Diepen 2008). Two approaches have been used to measure the respiration of fungal hyphae in situ; using mesh bound soil cores or mesh bound in-growth bags. Moyano et al. (2008) used mesh bound cores in combination with trenching methods to estimate the respiration of fungal hyphae. In order to calculate the respiration of mycorrhizal hyphae, the $\mathrm{CO}_{2}$ flux from the mycorrhizal free trenched cores was subtracted from the $\mathrm{CO}_{2}$ flux from the mesh bound cores, which included mycorrhizal fungi but no roots. This method does not allow fungal biomass to be easily obtained, and therefore it does not yield reliable biomass-specific respiration estimates. Van Diepen (2008) used the hyphal in-growth bag method to estimate fungal respiration, and showed that respiration is correlated with the amount of AMF biomass. This study was carried out using intact hyphal bags, which often inflated initial values of $\mathrm{CO}_{2}$ flux, causing non-linear respiration curves over time, and necessitating the use of blank hyphal in-growth bag corrections. The hyphal ingrowth bags yield relatively pure samples of fungal biomass, which aids in determining how the biomass production and biomass-specific respiration of fungal hyphae may change under experimental manipulation.

The goal of the present study was to determine how soil fungal hyphae respond to long-term soil warming. We improved upon existing methods to measure hyphal biomass-specific respiration using in-growth bags. Coarse sand was used to fill hyphal in-growth bags, since fine sand tends to stick to hyphae, particularly AMF hyphae, which produce glomalin (Smith and Read 2008). Sand was acid washed and combusted in order to remove all inorganic and organic nutrient sources. This helps to ensure that few free-living heterotrophs are able to colonize the in-growth bag. The design of the respiration chamber used was altered and the duration of respiration measurements was increased in order to more accurately capture $\mathrm{CO}_{2}$ flux from hyphal tissue. We hypothesized that, in the long-term, growth and respiration would demonstrate an apparent acclimation to the new environmental conditions at a 
higher temperature. This would be evidenced by lower hyphal biomass production and respiration in heated versus control plots.

\subsection{Methods}

Two ongoing soil-warming experiments at Harvard Forest, MA were used to examine the effects of long-term soil warming on fungal hyphae. The forests are even-aged mixed deciduous forests dominated by Acer rubrum L., Acer pensylvanicum L. and Quercus velutina Lam. Both experiments are heated with buried cables. The experiment at Prospect Hill has been heated $\left(+5^{\circ} \mathrm{C}\right)$ since 1991 (Peterjohn et al. 1994). Six heated and six control $6 \mathrm{~m}$ x $6 \mathrm{~m}$ plots were sampled, with two samples from each plot for biomass $(n=24)$. Hyphal respiration was recorded for four hyphal in-growth bags from each treatment $(n=8)$. The second warming experiment at Barre Woods has been heated since 2003 with one $30 \mathrm{~m}$ x 30 $\mathrm{m}$ plot per treatment (control and $+5^{\circ} \mathrm{C}$ ). Six $5 \mathrm{~m}$ x $5 \mathrm{~m}$ subplots from each treatment plot were sampled from Barre Woods, with two samples from each subplot for biomass $(n=24)$. Hyphal respiration was measured on three hyphal in-growth bags from each treatment $(n=6)$. Hyphal in-growth bags were deployed in 2010 to determine the relative abundance of fungi and bacteria in the hyphal in-growth bag environment using phospholipid fatty acid analysis (PLFA). In 2011 the amount of hyphal biomass in the hyphal in-growth bags was estimated using the filter flotation method, and the respiration of fungal hyphae was estimated using the total $\mathrm{CO}_{2}$ flux from a bag determined with an infrared gas analyzer.

The hyphal in-growth bag method was used to estimate hyphal biomass and respiration following Addy et al. (1994). This method uses bags made of fine mesh (55 $\mu \mathrm{m}$ pore size), which excludes roots and large soil dwelling organisms. The bags were filled with coarse sand ( $>500 \mu \mathrm{m}$ grain size), which was acid washed to remove inorganic nutrients, then combusted at $500{ }^{\circ} \mathrm{C}$ for 12 hours to remove organic nutrients. The lack of organic matter and nutrients discourages the growth of free-living heterotrophs. Fungal hyphae grow through the bag, allowing fungal tissue to be isolated from other soil organisms. Hyphal in-growth bags were placed 
horizontally $5 \mathrm{~cm}$ below the soil surface and incubated there for 2 months, from July to September 2011.

Immediately after harvest from the soil, the temperature of the hyphal ingrowth bag and surrounding soil were measured, and the respiration from the ingrowth bag was determined using a LiCor 8100 infrared gas analyzer with a custom built chamber. The chamber was built of $5 \mathrm{~mm}$ thick PVC pipe and is cylindrical with a diameter of $10 \mathrm{~cm}$ and a height of $10 \mathrm{~cm}$. The bags were opened and sand was emptied out into the chamber and exposed to the ambient atmospheric $\mathrm{CO}_{2}$ levels for 30 seconds before respiration measurements began. This allowed the relatively high $\mathrm{CO}_{2}$ concentration of the bag in the soil environment to equilibrate with the atmospheric $\mathrm{CO}_{2}$ concentration at which respiration would be measured. Respiration was measured for 10 minutes. Temperature of the sand was recorded again after the respiration measurement. The sample was then frozen at $-20^{\circ} \mathrm{C}$ until laboratory analysis could be performed. Blank bags were placed in the soil for 24 hours in the same location as the sample bags. The flux at the final $100 \mathrm{~s}$ of measurement was recorded for both blank and sample bags. Based on data from the Ford Forestry Center for blank hyphal in-growth bags (Chapter 3), the blank bag $\mathrm{CO}_{2}$ flux was correlated with the final $\mathrm{CO}_{2}$ concentration via a linear regression $\left(\mathrm{r}^{2}=0.56\right)$. The equation $\mathrm{CO}_{2}$ Flux $=0.26$ (Final $\mathrm{CO}_{2}$ Concentration $)+15.2$ was used as a blank correction for the sample bag flux.

The filter flotation method was used to extract the fungal biomass from the sand in the laboratory (Staddon et al. 1999). Briefly, sand was poured into a $2 \mathrm{~L}$ beaker and hyphae were removed from the mesh bag by hand using tweezers and small brushes. Deionized water was streamed over the bag surface to remove all tissue, and then $500 \mathrm{~mL}$ of tap water was added to the beaker. The sand and hyphal mixture was stirred rapidly until the hyphal tissue floated. The supernatant was then poured over a borosilicate glass fiber filter (GE Whatman 934-AH). This was repeated three times for each sample to remove the majority of hyphal biomass from the sand. Filters were prewashed and combusted prior to flotation, and filter dry weights were prerecorded. After undergoing floatation, each hyphal sample was 
dried on the filter at $50{ }^{\circ} \mathrm{C}$ for 24 hours and then placed in a desiccator for at least 12 hours before being weighed. Due to the sticky nature of fungal hyphae, some sand particles remain attached to the fungal biomass. To overcome this issue, after weighing, filters were combusted at $500^{\circ} \mathrm{C}$ for 12 hours to measure mass loss on ignition, and the sand remaining on each filter was weighed.

PLFA analyses were performed on subsamples from the sand substrate of the hyphal in-growth bags and surrounding soil in 2010. These analyses were used to ensure that the amount of bacteria growing in the sand substrate was minimal, and as another estimate of fungal biomass growing into the hyphal in-growth bags. PLFA analyses were carried out according to Frostegård et al. (1991). Briefly, cells were lysed with chloroform and methanol and total lipids were extracted in the chloroform layer. Phospholipid, glycolipid and neutral lipid fractions were separated with silicic acid chromatography. Phospholipids were then methylated and the length and structures of the resulting fatty acid methyl ester chains and their relative abundances were quantified using a gas chromatograph with a flame ionization detector (Agilent 6850). The amount of phospholipid fatty acid methyl esters was used to estimate relative abundance of bacteria and fungi. To estimate bacterial abundance the following fatty acids were used: 14:0, iso15:0, a15:0, 16:167, 10me16:0, iso17:0,

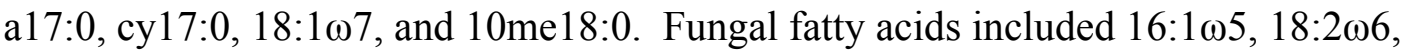

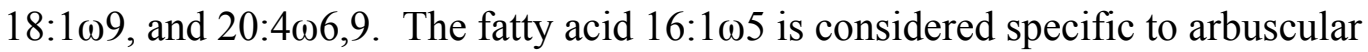
mycorrhizal fungi (Olsson et al. 1995).

In order to determine if our estimates of respiration per unit biomass were reasonable, respiration per unit biomass was scaled up from the hyphal in-growth bag level to a larger volume to compare with soil respiration measurements. We assumed that hyphal in-growth bag respiration at $5 \mathrm{~cm}$ depth was representative of hyphal respiration per $75 \mathrm{~cm}^{3}$ in the top $5 \mathrm{~cm}$ of the soil. We also assumed that most soil respiration takes place in the top $5 \mathrm{~cm}$ of the soil horizon. We scaled the estimate up to a $1 \mathrm{~m}^{2}$ soil area with $5 \mathrm{~cm}$ depth in order permit comparison to soil respiration data. We compared these fungal respiration estimates to estimates of soil respiration for heated and control plots from publicly available data for September of 
2010 from the Barre Woods experiment and August 2010 from the Prospect Hill experiment (http://harvardforest.fas.harvard.edu/data-archive).

SPSS statistics 21.0 was used to perform statistical analyses and make figures. We hypothesized that fungal PLFA content, hyphal biomass and respiration would be lower in the heated plots compared to the control plots. Plot averages were used in calculations. Student's t-tests were used to compare the PLFA content, hyphal biomass, flux per hyphal in-growth bag and respiration per unit biomass (hereafter referred to as biomass-specific respiration) in the control versus heated plots. Simple linear regression analyses were used to determine the impact of average bag measurement temperature and moisture content on hyphal biomass, flux per hyphal in-growth bag and biomass-specific respiration at Prospect Hill and Barre Woods. Alpha was set at 0.05 .

\subsection{Results}

The Prospect Hill experiment, which had been warmed for 18 years, did not show significant differences in fungal hyphal biomass $(P=0.908$, Figure 2.1$), \mathrm{CO}_{2}$ flux per bag $(P=0.278$, Figure 2.2), or biomass specific respiration $(P=0.151$, Figure 2.3). Both respiration measurements were approximately $50 \%$ lower in heated versus control plots, although this difference was not statistically significant. The average measurement temperature during the respiration measurement was $19.2^{\circ} \mathrm{C}$ for unheated plots and $25.3{ }^{\circ} \mathrm{C}$ for heated plots. The average moisture content of the hyphal in-growth bags was $2.27 \mathrm{~g}$ for unheated plots and $2.03 \mathrm{~g}$ for heated plots.

The Barre Woods experiment, which had been warmed for 8 years, had approximately $30 \%$ lower fungal biomass in heated versus control plots, although this difference was not statically significant $\left(P=0.324\right.$, Figure 2.4). The $\mathrm{CO}_{2}$ flux per bag was approximately 50\% lower in heated versus control plots $(P=0.047$, Figure 2.5). Biomass-specific respiration in warmed plots was approximately $18 \%$ of that in control plots $(P=0.003$, Figure 2.6). The average measurement temperature during respiration measurement was $18.5^{\circ} \mathrm{C}$ for unheated plots and $24.5^{\circ} \mathrm{C}$ for heated plots. The average moisture content of the hyphal in-growth bags was $3.03 \mathrm{~g}$ for unheated plots and $2.52 \mathrm{~g}$ for heated plots. 
The regression analyses predicting the hyphal biomass from hyphal ingrowth bag temperature and moisture were not significant (Table 2.1). At Barre Woods the linear regressions for temperature predicted $73.5 \%$ of hyphal in growth bag $\mathrm{CO}_{2}$ flux, and $92.3 \%$ of biomass specific respiration (Table 2.1). Moisture predicted $33.2 \%$ of hyphal in growth bag $\mathrm{CO}_{2}$ flux, and $58.1 \%$ of biomass specific respiration at Barre Woods (Table 2.1). At Prospect Hill the linear regressions for temperature predicted $25.2 \%$ of hyphal in growth bag $\mathrm{CO}_{2}$ flux, and $37.0 \%$ of biomass specific respiration (Table 2.1). Moisture was not a significant predictor of either hyphal in growth bag $\mathrm{CO}_{2}$ flux or biomass specific respiration at Prospect Hill (Table 2.1).

PLFA analyses on sand from the hyphal in-growth bags from 2010 show that fungal biomass dominated the in-growth bags with a bacterial to fungal PLFA ratio of approximately 1:4 (Table 2.2). In the hyphal in-growth bags, fatty acids of bacterial origin accounted for approximately $21 \%( \pm 15.39 \% \mathrm{SD})$ of the total PLFA content. Fungal fatty acids made up approximately $79 \%( \pm 15.39 \% \mathrm{SD})$ of the total PLFA content. In contrast, PLFA analyses of soils surrounding hyphal in-growth bags had an average bacterial to fungal PLFA ratio of approximately 1:1 (Table 2.2), with bacterial fatty acids composing $58 \%( \pm 14.10 \% \mathrm{SD})$ and fungal fatty acids composing $42 \%( \pm 14.10 \% \mathrm{SD})$ of the total PLFA content. Soils showed significantly higher total PLFA, bacterial PLFA and fungal PLFA content in the control versus heated treatments (Table 2.2). At Barre Woods the bacterial markers 14:0, a15:0, 10me16:0, i17:0, a17:0, cy17:0, and 10me18:0 from the hyphal bags were all significantly lower in heated versus control plots (Table 2.3). The fungal

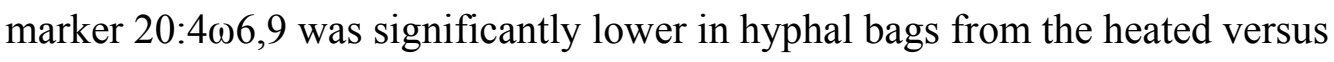
control plots from Barre Woods $(P=0.032)$. At Prospect Hill the bacterial markers a17:0 and 18:1 $\omega 9$ were significantly lower in hyphal bags from the heated versus control plots. The fungal marker 20:4 6 ,9 was also significantly lower in hyphal ingrowth bags from the heated versus control plots from Prospect Hill $(P=0.031)$. 


\subsection{Discussion}

The results suggest that belowground respiration of fungal hyphae decreases in response to long-term warmer soil temperatures. No other study known to the authors has directly looked at the impact of experimental warming on mycorrhizal hyphal respiration. Moyano et al. (2008) found a weak relationship between mycorrhizal respiration and measurement temperature, however temperature was not being manipulated in this study. In a short-term experiment, Atkin et al. (2003) manipulated temperature in inoculated and uninoculated plants in a mesocosm experiment and found that soil respiration was only higher in inoculated treatments at lower temperatures. These short-term results seem to support what we have found in this long-term field experiment, in that the mycorrhizal contribution to soil respiration decreases at higher temperatures. Our regression analyses showed that temperature had a negative impact on hyphal respiration. However, other short-term studies, in which pure fungal hyphae were isolated from bulk soil in a separate chamber to measure respiration, showed that hyphal respiration rates increased at higher incubation temperatures (Hawkes et al. 2008, Heinemeyer et al. 2006, Bååth and Wallander 2003). It is difficult to reconcile these short-term mesocosm study results with the results from the long-term soil warming field experiments that were sampled here. Mesocosm studies are typically implemented over relatively shorter time scales. Mesocosm studies also usually limit the types of organisms that interact in the soil to a single plant and mycorrhizal fungus. This enhanced control often limits validity of results when extrapolating to interactions that may take place at the ecosystem scale.

The mechanisms behind this response remain unclear. Soil fungi may exhibit a metabolic homeostasis response to long-term warming, or may become metabolically limited by factors other than temperature. In these experiments longterm warming has also led to increased evapotranspiration, which could make moisture a limiting factor (Frey et al. 2008). Our regression analyses show that the moisture content of the hyphal in-growth bags had a positive impact on hyphal respiration. Additionally, nitrogen is being cycled more rapidly in the heated versus 
control plots (Melillo et al. 2011, Butler et al. 2012). Either of these conditions could limit fungal hyphal respiration in the heated versus control plots. It has been suggested that the majority of fungal hyphae growing into hyphal in-growth bags are mycorrhizal (Van Diepen 2008, Wallander et al. 2001), and if more nitrogen is available to plants in warmed treatments it is possible that there is lower mycorrhizal infection in warmed versus control plots. This mechanism could explain the reduction in hyphal biomass in heated versus control plots. Hyphal respiration may also be lower where more nitrogen is available due to lower metabolic costs associated with obtaining nitrogen resources from the soil. Additionally, it is possible that a shift in the structure of the fungal community occurs with warming. The mycorrhizal fungal symbionts that are active in the warmed treatments may be more metabolically efficient than those that are active in the control treatments.

Biomass production was lower in the heated plot at Barre Woods; however this difference was not seen at Prospect Hill. The results from Prospect Hill may have been impacted by an interruption in heating during the previous year (November 2010 to July 2011). It is possible that the biomass of the fungi in the heated plots was higher, and therefore more similar to the control plots because of similar temperature conditions during the previous growing season. This could be attributed to an alleviation of moisture limitation in the heated plots. It is also possible that the relatively smaller plot size at Prospect Hill (6 m x $6 \mathrm{~m}$ ) versus Barre Woods $(30 \mathrm{~m} \times 30 \mathrm{~m})$ has an impact on fungal growth and respiration, since some trees have root systems that are not fully heated, because some of their roots grow outside of the heated plots. The biomass-specific hyphal respiration was lower in the heated versus control plots, suggesting a more permanent change in the metabolic physiology of the fungal hyphae in the heated plots, although this difference was not statistically significant, likely due to low statistical power. PLFA abundance estimates from Prospect Hill in 2010, prior to the heating interruption, indicate that fungal abundance tended to be lower in heated versus control plots. This lends further support to the hypothesis that fungal biomass is lower in the heated plots, given heating throughout the entire growing season. Root biomass is also lower in 
the heated plots versus the control plots (Burton et al. 2008), and it is possible that fungal biomass is lower in warmed soils due to a reduction in mycorrhizal fungal biomass.

Our results indicate that hyphal respiration contributes to approximately 12$63 \%$ of soil respiration. At Prospect Hill the fungal hyphal contribution to soil respiration was estimated to be $36 \%$ for heated plots and $48 \%$ for control plots. At the Barre Woods experiment fungal hyphal respiration contributed to approximately $12 \%$ of soil respiration in the heated plots and $63 \%$ of soil respiration in the control plots. This percentage contribution of hyphal respiration to total soil respiration is greater than previously published values for the contribution of hyphal respiration to total soil respiration from different ecosystems. For example, in the dissertation by Moyano (2008) $\mathrm{CO}_{2}$ flux was measured from mesh bound soil cores compared to unbound soil cores in a barley field and about $6 \%$ of $\mathrm{CO}_{2}$ flux could be attributed to mycorrhizal fungi.

The hyphal in-growth bag method has several inherent flaws that may lead to an overestimation of the fungal contribution to total soil respiration. First, it is impossible to avoid the disturbance of removing the in-growth bag from the soil. The mycorrhizal fungi receive their carbon from the host plant, and when the bag is removed from the soil all connections between the host plant and the fungus are severed. This may lead to a stress response, which could increase respiration rates. Alternatively, respiration rates might be lower due to the fugal tissue being separated from the carbon source from the roots. The mesh surrounding the hyphal in-growth bag generally allows nutrients and water to flow through the bag, however this often occurs at a slower rate than in the bulk soil, when the pore size of the mesh is smaller than the pore size of the soil particles. This may lead to an accumulation of water and nutrients in the hyphal in-growth bag, creating a growth environment that is much different from a typical soil environment. This accumulation of nutrients and water in the bag may allow bacteria to grow in the previously sterile sand, leading to artificially elevated estimates of hyphal respiration. Alternatively, the sand inside the hyphal in-growth bags may have lower moisture and nutrient concentrations due 
to large pore size between sand grains and low cation exchange capacity. The sand substrate inside of the in-growth bags is typically coarser than the surrounding soil, adding to the artificiality of the in-growth bag environment.

It can be difficult to capture enough fungal hyphae to measure either respiration or biomass in the hyphal in-growth bag. This may be due to the fact that fungal hyphae are not uniformly distributed in the soil, and the hyphal in-growth bag has a relatively small volume. Because of this issue, it seems logical to leave the hyphal in-growth bags in place for a long time in order to capture slow growing hyphae, however this can lead to turn-over of the hyphal biomass within the bag. Once fungal hyphae turnover inside of the bag, other microorganisms may begin to decompose the fungal tissue, which would also cause hyphal respiration to be overestimated. Our hyphal respiration results may have been impacted by low sample size, reducing power in the statistical analysis.

Hyphal in-growth bags offer one of the only methods to isolate fungal hyphae from other organisms growing in the soil to measure both biomass and respiration. The hyphal in-growth bags are relatively small compared to mesh bound cores, reducing the amount of space on experimental plots needed to measure hyphal respiration. This also allows fungal hyphae to colonize the bags more quickly, minimizing hyphal turnover. The hyphal in-growth bag method is a dependable approach to obtain samples of fungal hyphal biomass. The results of the PLFA analyses indicate that the sand substrate in the hyphal in-growth bags discriminates against the growth of bacteria.

Artifacts typically found in the measurement of hyphal respiration were overcome by emptying the sand substrate out of the mesh bag, and using a larger custom built chamber than in previous attempts. The larger chamber allowed the sand to be spread out so that the $\mathrm{CO}_{2}$ concentration in the sand substrate could quickly equilibrate with atmospheric $\mathrm{CO}_{2}$ concentrations after being removed from the relatively high $\mathrm{CO}_{2}$ concentrations in the soil. In previous attempts hyphal ingrowth bags were left intact, which slowed this equilibration, leading to initially large spikes in $\mathrm{CO}_{2}$ fluxes. Future studies using hyphal in-growth bags to measure 
biomass and respiration should test various time intervals for bag deployment to ensure that a suitable amount of biomass is obtained for respiration measurements, and alter chamber design to find the optimal methodology.

\subsection{Conclusion}

In conclusion, our results support our hypothesis that mycorrhizal fungal hyphae adjust to long-term warming by decreasing hyphal biomass and biomassspecific respiration. This is in accordance with the general pattern in soil respiration in most long-term soil warming studies (Oechel et al. 2000, Luo et al. 2001, Bradford et al. 2008). Our results suggest that fungal hyphal respiration contributes $12-63 \%$ to soil respiration. The hyphal in-growth bag method offers a reliable approach to obtain relatively pure samples of fungal hyphae from the soil to estimate hyphal biomass. The hyphal in-growth bag method likely overestimates the hyphal contribution to total soil respiration. In the future it will be important to obtain better estimates of the various components of soil respiration, including fungi, in order to come to a better understanding of how the soil system as a whole responds in elevated temperatures. 


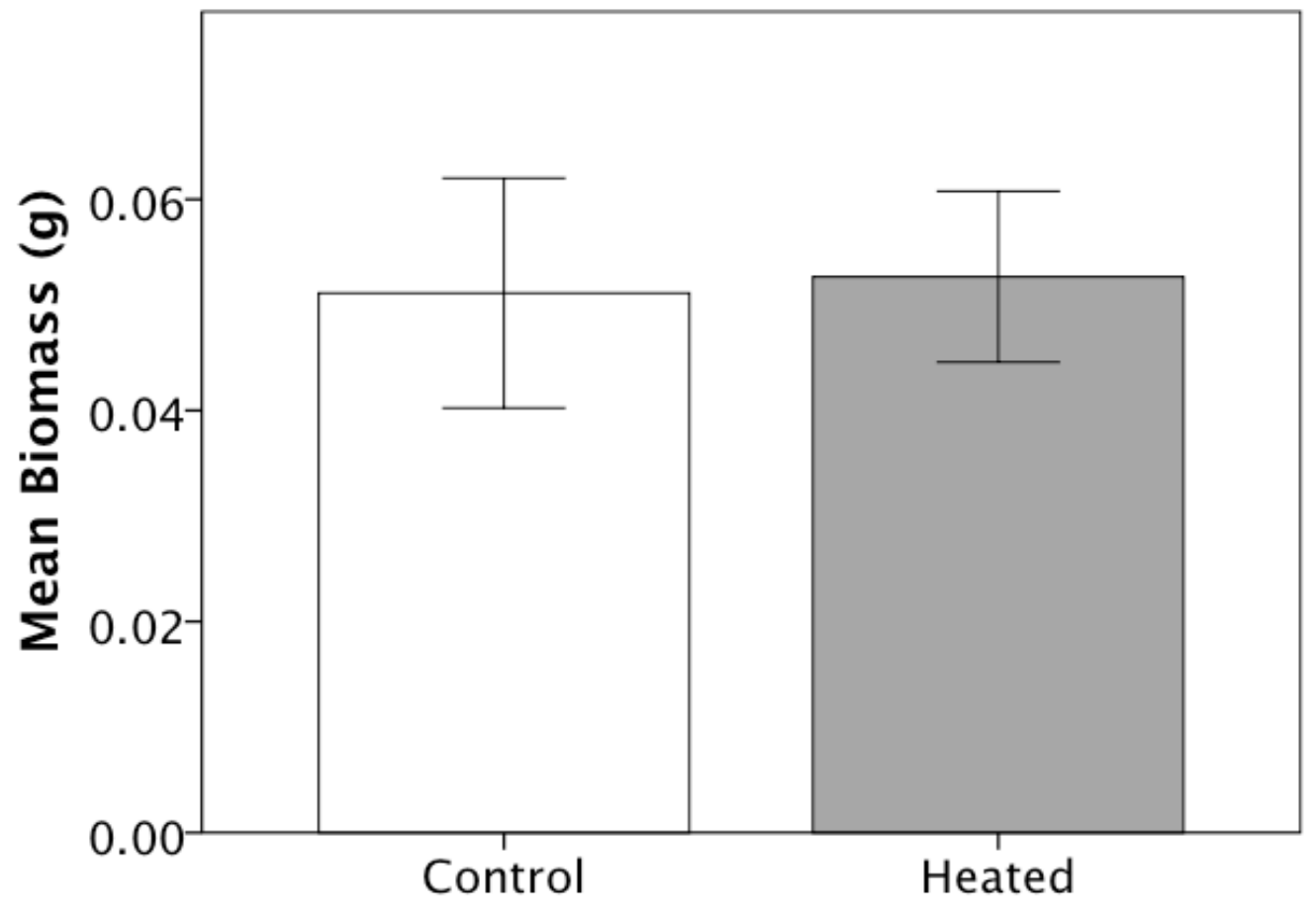

Treatment

Figure 2.1. Mean hyphal dry biomass (g) did not differ between control and heated treatments at Prospect Hill $(P=0.908)$. Error bars are one standard error of the mean. 


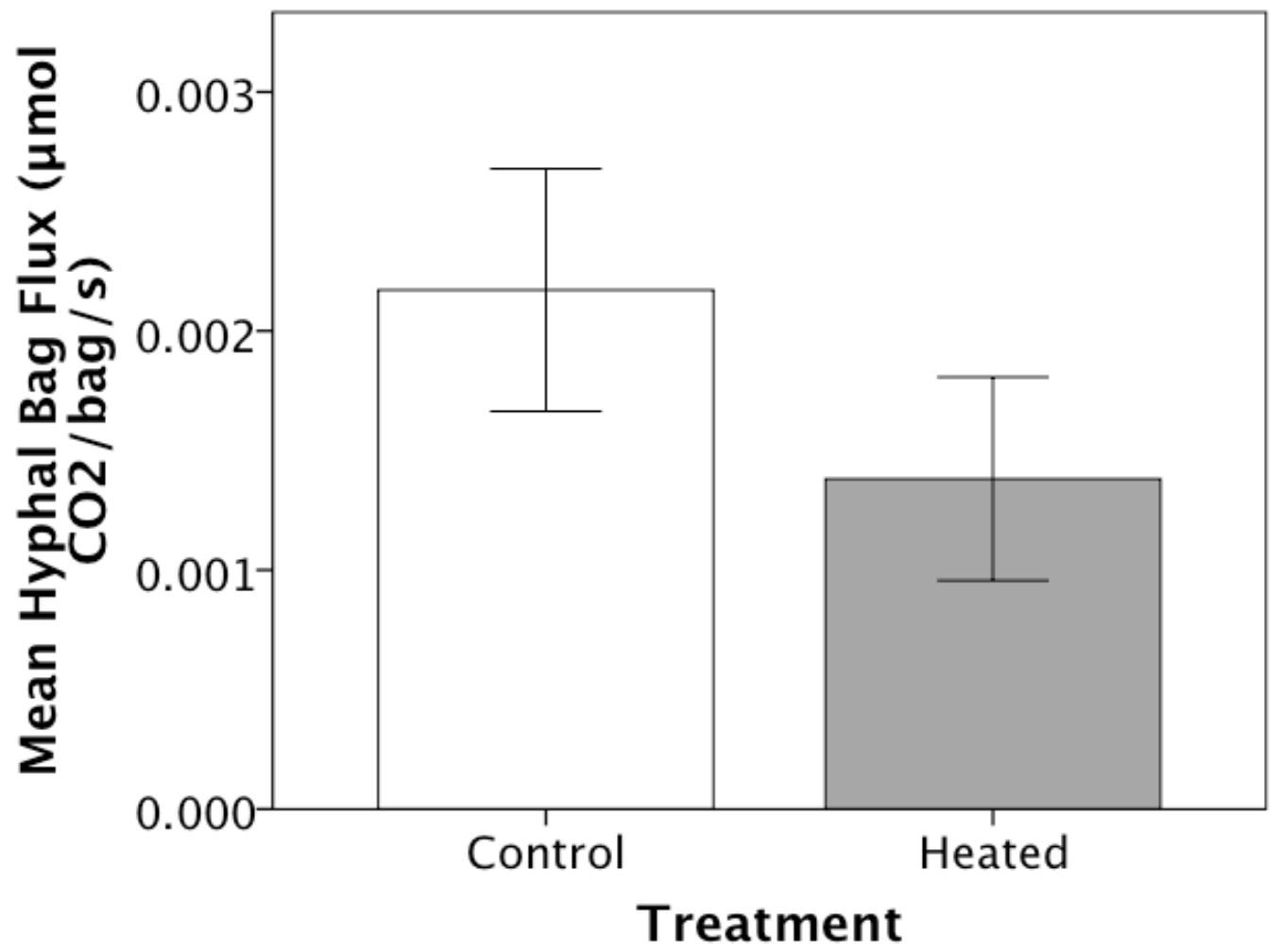

Figure 2.2 Mean flux per hyphal in-growth bag was not significantly different between heated and control plots at Prospect Hill $(P=0.278)$. Error bars are one standard error of the mean. 


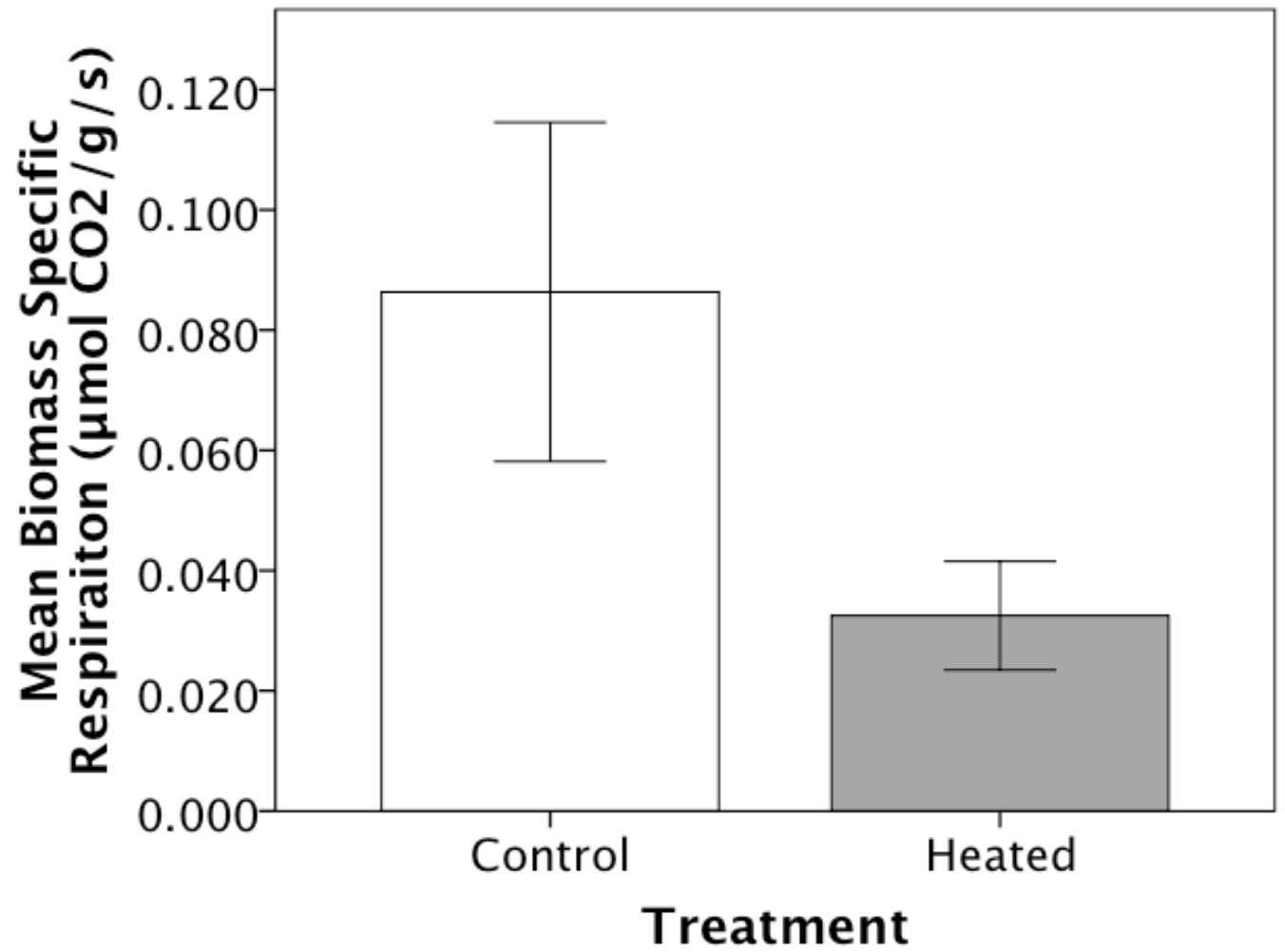

Figure 2.3 Mean hyphal respiration per unit dry biomass $\left(\mu \mathrm{mol} \mathrm{CO}_{2} \mathrm{~g}^{-1} \mathrm{~s}^{-1}\right)$ was not statistically different between heated and control treatments $(P=0.151)$ at Prospect Hill. Error bars are one standard error of the mean. 


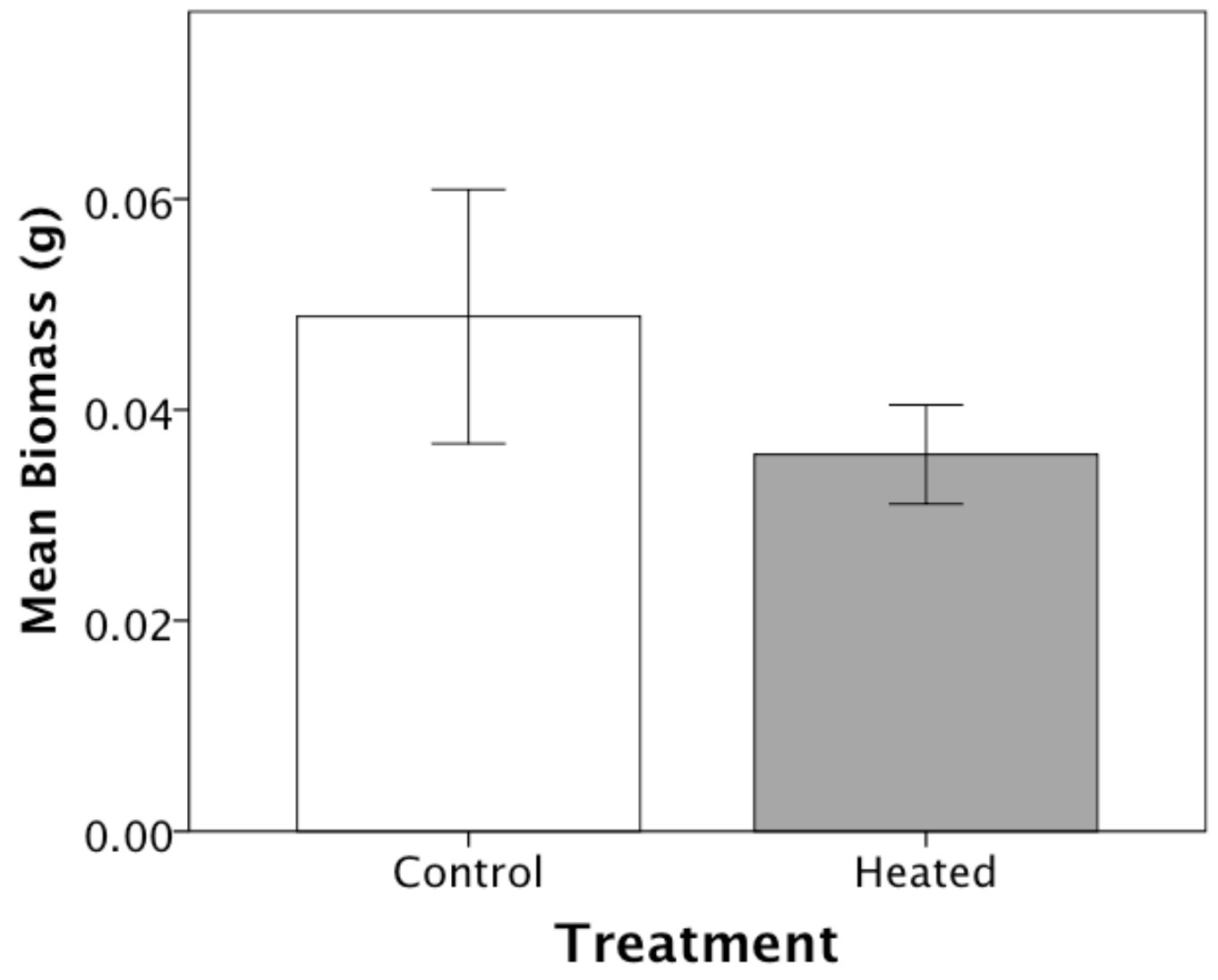

Figure 2.4 Mean hyphal dry biomass was not statistically different between heated and control treatments $(P=0.324)$ at Barre Woods. Error bars are one standard error of the mean. 


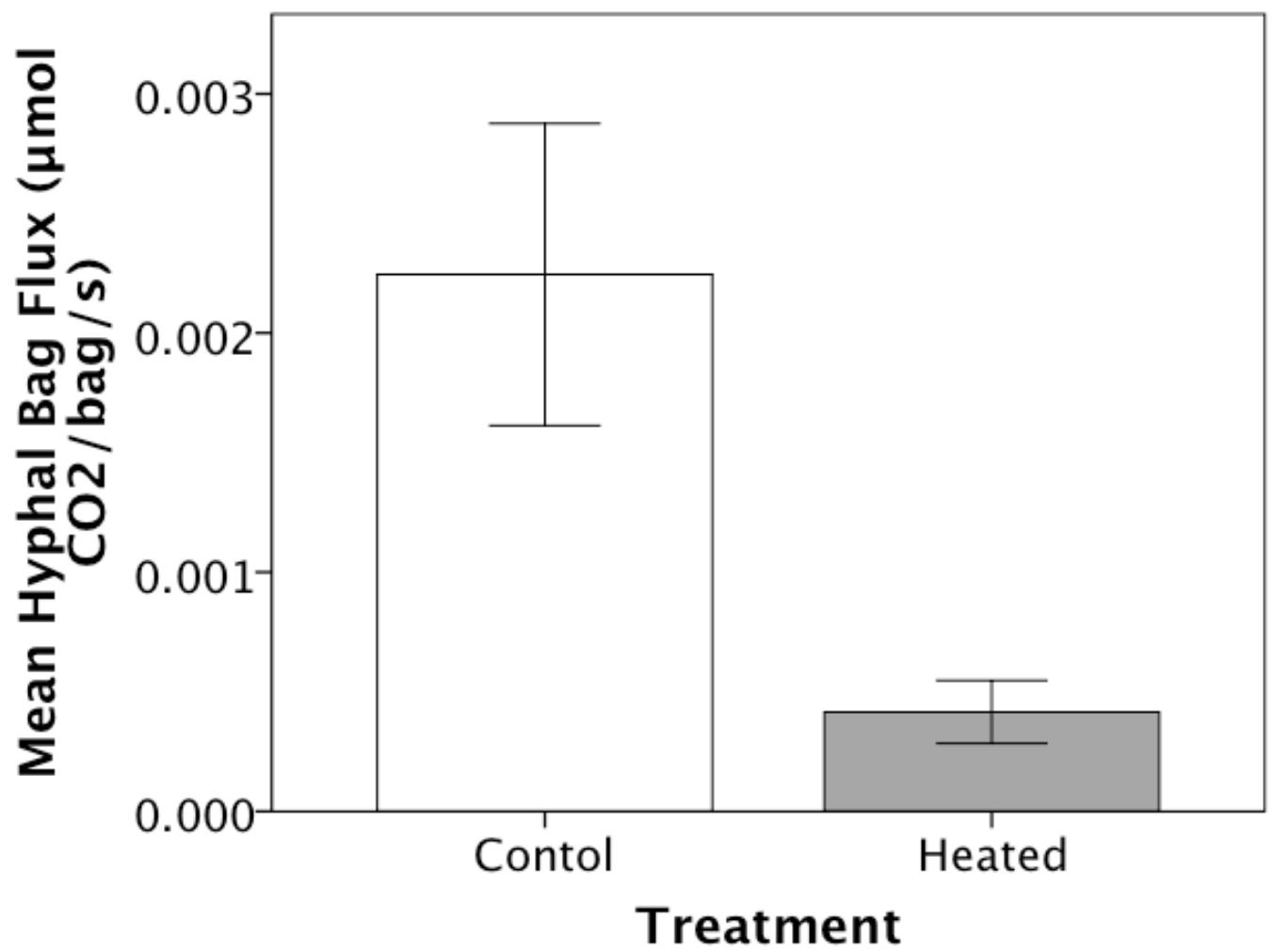

Figure 2.5 Mean flux per hyphal in-growth bag was lower in heated compared to control plots at Barre Woods $(P=0.047)$. Error bars are one standard error of the mean. 


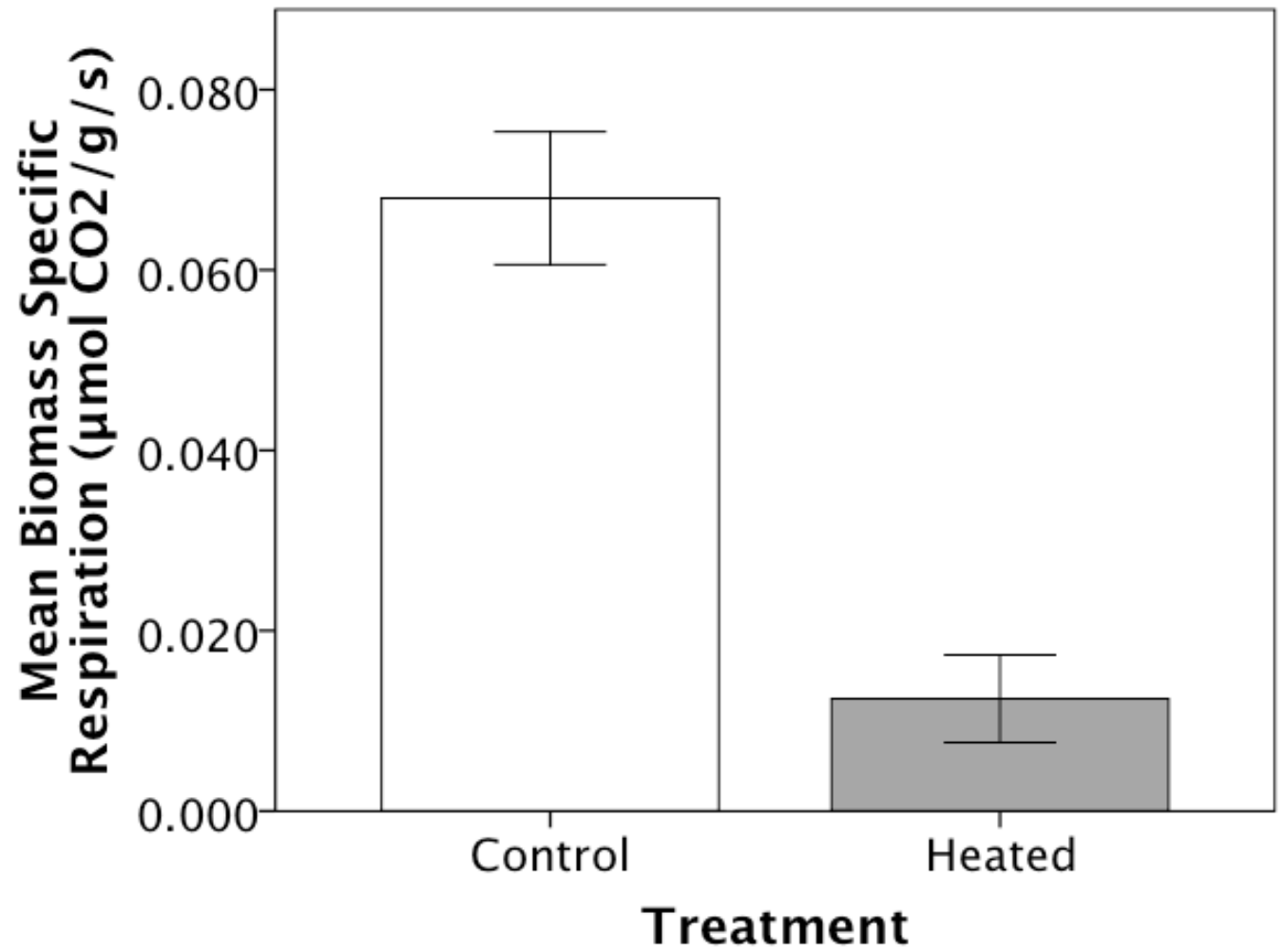

Figure 2.6 Mean hyphal respiration per unit dry mass $\left(\mu \mathrm{mol} \mathrm{CO} \mathrm{CO}^{-1} \mathrm{~s}^{-1)}\right.$ was lower in the heated versus control treatment at Barre Woods $(P=0.003)$. Error bars are one standard error of the mean. 
Table 2.1. Simple linear regressions using temperature and moisture as independent variables and biomass $(\mathrm{g})$, hyphal bag $\mathrm{CO}_{2}$ flux $\left(\mu \mathrm{mol} \mathrm{CO} \mathrm{Cag}^{-1} \mathrm{~s}^{-1}\right)$ and biomass specific respiration $\left(\mu \mathrm{mol} \mathrm{CO} \mathrm{CO}^{-1} \mathrm{~s}^{-1}\right)$ as dependent variables. Equations and $r^{2}$ are given for each regression.

\begin{tabular}{|c|c|c|}
\hline Site & Equation & $\mathrm{r}^{2}$ \\
\hline \multirow{6}{*}{$\begin{array}{l}\text { Barre } \\
\text { Woods }\end{array}$} & biomass $=0.091-0.002$ (temperature) & 0.050 \\
\hline & biomass $=0.030+0.005$ (moisture) & 0.017 \\
\hline & hyphal bag flux $=0.008-0.0003$ (temperature) & 0.735 \\
\hline & hyphal bag flux $=-0.0003+0.0008$ (moisture) & 0.332 \\
\hline & $\begin{array}{l}\text { biomass specific respiration }=0.246- \\
0.010(\text { temperature })\end{array}$ & 0.923 \\
\hline & $\begin{array}{l}\text { biomass specific respiration }=- \\
0.015+0.026 \text { (moisture) }\end{array}$ & 0.581 \\
\hline \multirow{6}{*}{$\begin{array}{l}\text { Prospect } \\
\text { Hill }\end{array}$} & biomass $=0.045+0.0003$ (temperature) & 0.011 \\
\hline & biomass $=0.043+0.004$ (moisture) & 0.006 \\
\hline & hyphal bag flux =0.005-0.0001 (temperature) & 0.252 \\
\hline & hyphal bag flux $=0.001+0.0004$ (moisture) & 0.087 \\
\hline & $\begin{array}{l}\text { biomass specific respiration }=-0.256- \\
0.0089 \text { (temperature) }\end{array}$ & 0.370 \\
\hline & $\begin{array}{l}\text { biomass specific } \\
\text { respiration }=0.0061+0.028 \text { (moisture) }\end{array}$ & 0.157 \\
\hline
\end{tabular}

Table 2.2. Mean PLFA content (nmol/g) of sand in hyphal in-growth bags and surrounding soil by treatment in 2010 at Prospect Hill and Barre Woods. Significance by treatment is indicated by * at $\alpha=0.10 * *$ at $\alpha=0.05, * * *$ at $\alpha=0.01$, and $* * * *$ at $\alpha=0.001$.

\begin{tabular}{lllll} 
& Sand & & Soil & \\
& Heated & Control & Heated & Control \\
\hline Bacterial PLFA & 0.802 & 0.800 & $159^{* * * *}$ & $273^{* * * *}$ \\
\hline Fungal PLFA & 2.84 & 2.93 & $190^{*}$ & $304^{*}$ \\
\hline Total PLFA & 3.64 & 3.72 & $385^{* *}$ & $577^{* *}$ \\
\hline \% Bacteria & 22.0 & 21.4 & 41.3 & 47.4 \\
\hline \% Fungi & 78.0 & 78.6 & 49.3 & 52.6 \\
\hline B:F & $\sim 1: 4$ & $\sim 1: 4$ & $\sim 1: 1$ & $\sim 1: 1$
\end{tabular}


Table 2.3. Mean PLFA content (nmol/g) of sand in hyphal bags by site and treatment according to species of fatty acid from 2010. Note 14:0, iso15:0, a15:0,

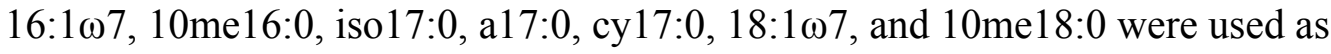

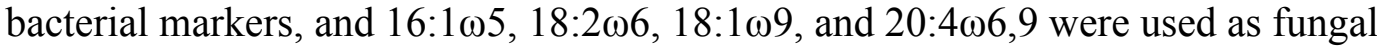
markers. Significance is indicated by $*$ at $\alpha=0.10, * *$ at $\alpha=0.05$, and $* * *$ at $\alpha=0.01$

\begin{tabular}{|c|c|c|c|c|c|}
\hline & & \multicolumn{2}{|c|}{$\begin{array}{c}\text { Barre } \\
\text { Woods }\end{array}$} & \multicolumn{2}{|l|}{$\begin{array}{l}\text { Prospect } \\
\text { Hill }\end{array}$} \\
\hline & $\begin{array}{l}\text { Type of } \\
\text { Marker }\end{array}$ & Heated & Control & Heated & Control \\
\hline 14:0 & Bacteria & 0 & $0.011 * *$ & 0.035 & 0.017 \\
\hline iso15:0 & Bacteria & 0.018 & 0.038 & 0.102 & 0.082 \\
\hline a15:0 & Bacteria & 0 & $0.001 * *$ & 0.057 & 0.109 \\
\hline $16: 1 \omega 7$ & Bacteria & 0.043 & 0.089 & 0.176 & $0.121 *$ \\
\hline 10me16:0 & Bacteria & 0 & $0.004 * *$ & 0.049 & 0.033 \\
\hline iso17:0 & Bacteria & 0 & $0.007 * *$ & 0.005 & 0.006 \\
\hline a17:0 & Bacteria & 0 & $0.007 * *$ & 0.003 & 0.011 \\
\hline cy17:0 & Bacteria & 0 & $0.010 * *$ & 0.034 & $0.016^{* *}$ \\
\hline 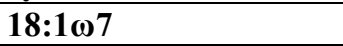 & Bacteria & 0.069 & 0.045 & 0.198 & 0.136 \\
\hline 10me18:0 & Bacteria & 0 & $0.036 * *$ & 0.012 & 0.019 \\
\hline $16: 1 \omega 5$ & Fungi & 0.199 & 0.191 & 0.558 & 0.602 \\
\hline 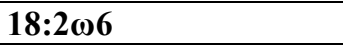 & Fungi & 1.46 & 1.41 & 0.384 & 0.362 \\
\hline 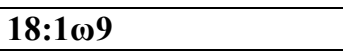 & Fungi & 0.099 & 0.138 & 0.143 & $0.204 * *$ \\
\hline $20: 4 \omega 6,9$ & Fungi & 0 & $0.007 * *$ & 0 & $0.011 * *$ \\
\hline Total Bacterial PLFA & Summary & 0.131 & 0.247 & 0.671 & 0.550 \\
\hline Total Fungal PLFA & Summary & 1.76 & 1.75 & 1.08 & 1.18 \\
\hline Total PLFA & Summary & 1.89 & 1.99 & 1.76 & 1.73 \\
\hline$\%$ Bacteria & Summary & 6.92 & 12.4 & 38.2 & 31.9 \\
\hline \% Fungi & Summary & 93.1 & 87.6 & 61.7 & 68.3 \\
\hline Bacteria:Fungi & Summary & $\sim 1: 13$ & $\sim 1: 7$ & $\sim 1: 2$ & $\sim 1: 2$ \\
\hline
\end{tabular}




\subsection{References}

Addy, H.D., Schaffer, G.F., Miller, M.H. and R.L. Peterson. 1994. Survival of the external mycelium of a VAM fungus in frozen soil over winter. Mycorrhiza. 5(1):15 .

Andrew C.J., Van Diepen, L.T.A, Miller M.R. and E.A. Lilleskov. In review. Quantifying aspen-associated mycorrhizal fungal production and respiration as a function of changing $\mathrm{CO}_{2}, \mathrm{O}_{3}$, and climatic variables. Fungal Ecology

Atkin, O.K., and M.G. Tjoelker. 2003. Thermal acclimation and the dynamic response of plant respiration to temperature. TRENDS in Plant Science. 8(7): 343351.

Atkin, O.K., Sherlock, D., Fitter, A.H., Jarvis, S., Hughes, J.K., Campbell, C., Hurry, V. and A. Hodge. 2008. Temperature dependence of respiration in roots colonized by arbuscular mycorrhizal fungi. New Phytologist. 1-12.

Bååth, E. and H. Wallander. 2003. Soil and rhizosphere microorganisms have the same Q10 for respiration in a model system. Global Change Biology. 9, 1788-1791.

Bond-Lamberty, B. and A. Thomson. 2010. Temperature-associated increases in the globabl soil respiration record. Science. 464: 579-582.

Bradford, M.A., Davies, C.A., Frey, S.D., Maddox, T.R., Melillo, J.M., Mohan, J.E., Reynolds, J.F. and K.K. Treseder. 2008. Thermal adaptation of soil microbial respiration to elevated temperatures. Ecology Letters. 11: 1316-1327.

Burton, A.J. Melillo, J.M. and S.D. Frey. 2008. Adjustment of forest ecosystem root respiration as temperature warms. Journal of Integrative Plant Biology. 50: 1467-1483.

Butler, S.M., Melillo, J.M., Johnson, J.E., Mohan, J., Steudler, P.A., Lux, H., Burrows, E., Smith, R.M., Vario, C.L., Scott, L., Hill, T.D., Aponte, N. and F. Bowles. 2012. Soil warming alters nitrogen cycling in a New England forest: implications for ecosystem function and structure. Oecologia. 168: 819-828.

Chistensen, J. H. et al. 2007. Chapter 11: Working Group I $4^{\text {th }}$ Assessment Report of the IPCC.

Frey, S.D., Drijber, R., Smith, H. and J. Melillo. 2008. Microbial biomass, functional capacity, and community structure after 12 years of soil warming. Soil Biology and Biochemistry. 40: 2904-2907. 
Frostegård, A., Tunlid, A. and E. Bååth. 1991. Microbial biomass measured as total lipid phosphate in soils of different organic content. Journal of Microbiological Methods. 14: 151-163.

Hawkes, C.V., Hartley, I.P., Ineson, P. and A.H. Fitter. 2008 Soil temperature affects carbon allocation within arbuscular mycorrhizal networks and carbon transport from plant to fungus. Global Change Biology. 14, 1181-1190.

Heinemeyer, A., Ineson, P., Ostle, N. and A.H. Fitter. 2006. Respiration of the external mycelium in the arbuscular mycorrhizal symbiosis shows strong dependence on recent photosynthates and acclimation to temperature. New Phytologist. 171, $159-170$.

Kellner, H., Vandenbol, M. and D. Zak. 2010. Fungi unearthed: Transcripts encoding lignocellulolytic and chitinolytic enzymes in forest soils. PLOS ONE. 5(6): e10971. doi:10.1371/journal.pone.0010971

Koch, N., Andersen, C.P., Raidl, S., Agerer, R., Matyssek, R. and T.E.E. Grams. 2007. Temperature-Respiration Relationships Differ in Mycorrhizal and NonMycorrhizal Root Systems of Picea abies (L.) Karst. Plant Biology. 9, 545-549.

Luo et al. 2001 Luo, Y., Wan, S., Hui, D., Wallace, L.L., 2001. Acclimatization of soil respiration to warming in a tall grass prairie. Nature. 413: 622-624.

Malcolm, G.M., López-Gutiérrez, J.C, Koide, R.T. and D. M. Eissenstat. 2008. Acclimation to temperature and temperature sensitivity of metabolism by ecotmycorrhizal fungi. Global Change Biology. 14, 1169-1180.

Meehl, G. A. et al. In: Climate Change 2007: The Physical Science Basis. Contribution of Working Group I to the Fourth Assessment Report of the Intergovernmental Panel on Climate Change. Solomon, S. et al. (eds.). Cambridge University Press: New York, New York, USA.

Melillo, J. M. et al. 2002. Soil warming and carbon cycle feedbacks to the climate system. Science. 298(5601): 2173-2176.

Melillo, J., Butler, S., Johnson, J., Mohan, J., Steudler, P., Lux, H., Burrows, E., Bowles, F., Smith, R., Scott, L., Vario, C., Hill, T., Burton, A., Zhou, Y. and J. Tang. 2011. Soil warming, carbon-nitrogen interactions, and forest carbon budgets. PNAS. 8(23): 9508-9512.

Moyano, F. E. 2008. Dissertation. Soil Respiration Fluxes and Controlling Factors in Temperate Forest and Cropland Ecosystems. 
Moyano, F.E., Kutsch, W.L. and C. Rebmann. 2008. Soil respiration fluxes in relation to photosynthetic activity in broad-leaf and needle-leaf forest stands. Agriculture and Forest Meteorology. 148: 135-143.

Peterjohn, T., Melillo, J.M., P.A. Steudler, Newkirk, K.M, Bowles, F.P. and J.D. Aber. 1994. Responses of trace gas fluxes and $\mathrm{N}$ availability to experimentally elevated soil temperatures. Ecological Applications. 4: 617:625.

Oechel, W.C., Vourlitis, G.L., Hastings, S.J., Zulueta, R.C., Hinzman, L., Kane, D., 2000. Acclimation of ecosystem CO2 exchange in the Alaskan Artic in response to decadal climate warming. Nature. 406: 978-981.

Olsson, P.A., Bååth, E., Jakobsen, I. and B. Söderström. 1995. The use of phospholipid andneutral lipid fatty acids to estimate biomass of arbuscular mycorrhizal fungi insoil. Mycological Research. 99: 623-629.

Raich, J. W. and C. S. Potter. 1995. Global patterns of carbon dioxide emissions from soils. Global Biogeochemical Cycles. 9: 23-36.

Reth, S. Graf, W., Reichstein, M. and J.C. Munch. 2009. Sustained stimulation of soil respiration after 10 years of experimental warming. Environmental Research Letters. 4: 1-5.

Smith, S.E. and D.J. Read. 2008. Mycorrhial Symbiosis, Third Edition. Academic press, Elsevier. London, UK.

Staddon, P.L., Fitter, A.H., and J.D. Graves. 1999. Effect of elevated atmospheric $\mathrm{CO} 2$ on mycorrhizal colonization, external mycorrhizal hyphal production and phosphorus inflow in Plantago laneolata and Trifolium repens in association with the arbuscular mycorrhizal fungus Glomus mosseae. Global Change Biology. 5: 347-358.

Van Diepen, L. 2008. The role and diversity of arbuscular mycorrhizal fungi in Acer saccharum dominated forest ecosystems under natural and $\mathrm{N}$-amended conditions. Michigan Technological University, Ph.D. dissertation.

Wallander, H., Nilsson, L.O., Hagerberg, D. and E. Baath. 2001. Estimation of the biomass and seasonal growth of external mycelium of ectomycorrhizal fungi in the field. New Phytologist. 151: 753-760. 


\section{Chapter 3: Growth and Respiration of Arbuscular Mycorrhizal Fungal Hyphae are Negatively Impacted by Elevated Soil Temperature and Drought ${ }^{2}$}

\subsection{Abstract}

The physiological activity of arbuscular mycorrhizal fungi (AMF) may be altered by changes in soil temperature and moisture availability. The ways in which AMF respond to these environmental factors will impact soil respiration and nutrient acquisition by host plants. We hypothesized that soil warming and moisture addition would increase the growth and respiration of AMF hyphae. Hyphal in-growth bags were used to isolate AMF hyphae from the soil in order to study the growth and respiration of AMF hyphae. The study site was located at the Ford Forestry Center in the Upper Peninsula of Michigan in a sugar maple dominated forest. Experimental manipulations included warming $\left(+5^{\circ} \mathrm{C}\right)$ and moisture addition $(+$ $30 \%$ ambient growing season precipitation) in a fully factorial randomized block design. Results indicate that seasonal drought can have a large impact on the growth and respiration of fungal hyphae. Contrary to our hypotheses, soil-warming and moisture addition did not have a significant impact on hyphal biomass production. There was nearly an order of magnitude lower $\mathrm{CO}_{2}$ flux per gram of hyphae in 2012 than 2011, likely due to increased respiration as a stress response to a severe regional drought in 2011. These findings suggest that the frequency and duration of drought events may be important factors influencing AMF growth and respiration. Soil warming generally increases evapotranspiration, decreasing soil moisture content. Lower soil moisture will likely cause the biomass production of AMF hyphae to decline in northern temperate forests. Additionally, higher respiration of AMF hyphae may result in a larger carbon cost to host plants, making AMF less efficient symbionts during drought years.

${ }^{2}$ Chapter 3 has been formatted for submission to Global Change Biology. It is currently under revision. The order of authors for this article will be Carley Kratz, Erik Lilleskov and Andrew Burton. Carley Kratz, Andrew Burton and Erik Lilleskov have all contributed to the written portion of the text. Andrew Burton oversaw the experimental site. Carley Kratz, Andrew Burton and Erik Lilleskov contributed to the methodological design. Data was collected and processed by Carley Kratz. 


\subsection{Introduction}

As climate changes it is important to understand how different aspects of climate will impact soil biota, including mycorrhizal fungi. Mycorrhizal fungi provide an important link between below and aboveground systems. The mycorrhizal fungus receives photosynthate in the form of simple sugars from a host plant, and in return the fungus provides the plant with nutrients from the soil (Smith and Read 2009). Arbuscular mycorrhizal fungi (AMF) are obligate symbionts belonging to the phylum Glomeromycota (Schüßler et al. 2001). AMF are distributed worldwide, forming associations with most terrestrial plants, yet relatively little is known about how these ubiquitous fungal symbionts respond to climate change.

Understanding how environmental factors such as temperature and moisture impact fungal growth and respiration will enhance the accuracy of ecosystem carbon and nutrient cycling models (Meehl et al. 2007). AMF can be an important source of soil respiration, particularly in forests where AMF host plants are prevalent. AMF also aid plants in obtaining nutrients, so their activity is inherently linked to the cycling of soil nutrients such as nitrogen. Yet how AMF respond to higher temperatures remains unclear. In plants, it is possible that higher temperatures will lead to higher growth and respiration on an exponential scale if metabolic acclimation does not occur (Atkin and Tjoelker 2003). Aside from metabolic acclimation, substrates required for growth and respiration can become limiting overtime, causing growth and respiration to decline (Mellilo et al. 2002). This pattern has been noted for soil respiration in long-term warming studies (Oechel et al. 2000, Luo et al. 2001, Mellilo et al. 2002, Bradford et al. 2008), although the exact mechanisms and the organisms involved remain unclear. In addition to substrate limitation, organisms may exhibit a homeostasis response by growing new tissues and macromolecules that are more efficient under the new environmental conditions (Atkin and Tjoelker 2003).

Because AMF are obligate symbionts, it is challenging to partition AMF tissue from the root tissue of the host plant. Furthermore, AMF hyphae grow in the opaque matrix of the soil. This makes it difficult to measure the effects that 
environmental changes have on AMF physiology in situ. Mesocosm experiments are typically used to overcome this hurdle because a greater degree of control can be maintained than in field experiments. One approach that has been used in AMF mesocosm studies is to compare the respiration of inoculated and uninoculated plant roots. These studies often show that inoculated roots have higher respiration rates than uninoculated roots, however it is unclear if this is due to greater metabolic activity of the fungus or root (Atkin et al. 2008, Hawkes et al. 2008, Heinemeyer et al. 2006, Grimoldi et al. 2006, Wright et al. 1998, Pearson and Jakobsen 1993, Peng et al. 1993, Nielsen et al. 1998, Baas et al. 1989). Few of these studies have looked directly at the impact of temperature on AMF respiration. Heinemeyer et al. (2006) found that $\mathrm{AMF}$ hyphal biomass increased in plants grown at temperatures $6{ }^{\circ} \mathrm{C}$ above ambient and that hyphal respiration acclimates to warmer temperatures after two weeks of warming. Interestingly, the respiration of AMF was more strongly related to photosynthetically active radiation (PAR) than to temperature. Hawkes et al. (2008) also found that AMF respiration was strongly linked to PAR in a shortterm mesocosm study with a $6{ }^{\circ} \mathrm{C}$ increase in soil temperature. In that study AMF biomass production and respiration both increased at higher temperatures. Atkin et al. (2008) showed that the respiratory response of plant roots to temperature change is less dramatic when plants are inoculated with AMF compared to uninoculated plants. In the field nearly all plants are inoculated with AMF, so examining the response of uninoculated plants to temperature change may not be representative of natural processes. In this study we examined AMF biomass production and respiration in field soils from a temperate forest in situ.

Field based studies have used fine nylon mesh to partition AMF hyphae from plant roots. One approach using this mesh is to create a mesh bound soil core belowground (Johnson et al 2002, Moyano 2008). Mesh bound cores provide a nondestructive way to estimate AMF contributions to soil respiration, but do have some methodological artifacts. It is impossible to determine the amount of fungal biomass in the cores without destructively harvesting them. The mesh core may not be fully colonized by AMF hyphae due to its relatively large diameter, which can lead to 
underestimates of the contribution of AMF to soil respiration. Additionally, the AMF contribution to soil respiration can be overestimated if diffusion of $\mathrm{CO}_{2}$ into the core from surrounding soil is not carefully accounted for.

Alternatively, smaller hyphal in-growth mesh bags can be used to partition AMF tissue from plant root tissue in the field. This method allows AMF tissue to be separated from plant roots and other soil organisms so that AMF physiology can be studied directly. In a chronic nitrogen $(\mathrm{N})$ addition experiment, Van Diepen (2008) used hyphal in growth bags to measure production and respiration of AMF and found that specific respiration of AMF was not altered by soil $\mathrm{N}$ availability, however the amount of AMF in the soil and in roots did decline significantly with greater $\mathrm{N}$ availability. In this case, it is possible that $\mathrm{N}$ addition caused lower $\mathrm{C}$ allocation to the AMF, resulting in lower AMF biomass in the soil and a reduction in total ecosystem AMF respiration. No published study known to the authors has focused on the combined impact of changes in temperature and moisture on AMF. One major goal of this study was to determine the degree to which hyphal in-growth bags are able to isolate soil fungi from bacteria. We were particularly interested in isolating AMF because AMF host trees dominate the overstory in this forest, making AMF a key organism involved in soil carbon and nutrient cycling in this ecosystem.

In this study we examined changes in AMF physiology in response to increased temperature $\left(+5{ }^{\circ} \mathrm{C}\right)$ and moisture $(+30 \%$ of ambient growing season $)$ in a northern hardwood forest dominated by sugar maple. Specifically, we measured biomass and respiration of AMF tissue using the hyphal in-growth bag method. We assumed that both growth and respiration of AMF would be limited by temperature and moisture. This may be related to greater $\mathrm{C}$ allocation to AMF from the host plant when soil temperature and moisture inputs are not limiting. Higher AMF growth and respiration could also be mediated by higher amounts soil nutrients when temperature and moisture are elevated. We hypothesized that biomass and respiration would be highest in treatments with both elevated temperature and moisture and lowest in the control treatment. We expected that increasing 
temperature or moisture alone would also lead to an increase in biomass and respiration, but not as substantially as when both factors were increased together.

\subsection{Methods}

This climate change study, combining increased temperature and moisture inputs, was conducted at the Ford Forestry Center in the Upper Peninsula of Michigan (46 $38^{\prime} 26.17^{\prime \prime} \mathrm{N} 88^{\circ} 29^{\prime} 00.94$ ' W, $400 \mathrm{~m}$ elevation). This secondgrowth forest has been managed for sugar maple (Acer saccharum Marsh.) sawtimber and last received a single tree selection harvest in 1998. Sugar maple, a host to AMF, dominates the basal area of the plots, comprising $89.3 \%$ of the $24.3 \mathrm{~m}^{2}$ $\mathrm{ha}^{-1}$ of overstory basal area (See Chapter 1 for more details).

The experiment is a $2 \times 2$ fully factorial randomized complete block design, including two levels of warming (ambient and $+5^{\circ} \mathrm{C}$ ) and two levels of moisture addition (ambient and $+30 \%$ of average ambient growing season precipitation). There are three blocks with no replication within blocks for a total of twelve $10 \mathrm{~m} \mathrm{x}$ $10 \mathrm{~m}$ plots. Warming was achieved via overhead infrared lamps suspended $1.5 \mathrm{~m}$ over the soil surface. Precipitation was collected from the roof of a nearby building at the Ford Center, stored in holding tanks, and then dispersed over the plots following rain events via sprinklers at each plot corner. Treatments were initiated in mid-September of 2010, and applied during the snow-free seasons of 2010 (through mid-November), 2011 (17 April to 11 November) and 2012 (25 March to 24 October).

Hyphal in-growth bags were used to estimate the growth and respiration of AMF (Addy et al. 1994). The cylindrical $75 \mathrm{~cm}^{3}$ bags are approximately $10 \mathrm{~cm}$ long and made of a fine nylon mesh ( $55 \mu \mathrm{m}$ pore size), which is filled with coarse sand $(>500 \mu \mathrm{m})$. Fungal hyphae can enter through the small pores of the mesh, which also allows nutrients and water to move through the bag, but excludes the entrance of plant roots or soil macrofauna. The sand was acid washed to remove inorganic nutrients, and then combusted at $500{ }^{\circ} \mathrm{C}$ for 12 hours before being placed in the hyphal in-growth bags so it was devoid of organic matter, making it difficult for free living heterotrophs to proliferate in the bag environment. 
Prior to initiating this study, hyphal in-growth bags were buried in the forest near the study plots and harvested at intervals of two weeks, one month, two months, four months and six months. The contents of these bags were examined using a microscope to sort sand grains from fungal hyphae. After two weeks and one month of incubation in the soil the majority of hyphal in-growth bags did not contain any fungal hyphae. After 2 months of incubation some fungal hyphae were present, however the biomass was not large enough to be reliably measured in most cases. After 6 months of incubation many of the hyphal in-growth bags contained necromass, determined by the presence of melanized hyphae that fragmented easily. We therefore chose 4 months as a reasonable incubation period for AMF hyphal ingrowth bag incubation in this system.

Hyphal in-growth bags were buried for 120 days from May to September of 2011 and 2012. The hyphal in-growth bags were buried horizontally $5 \mathrm{~cm}$ below the soil surface. Five bags were buried in the central $8 \mathrm{~m} \times 8 \mathrm{~m}$ of each plot, one at each corner and one in the center. There is some pit and mound topography, and during the course of this study we avoided deeper pits for sampling because they were sometimes flooded in the spring following snowmelt. The temperature of the sand inside of each in-growth bag was measured before removal from the soil, following removal from the soil and again following a 10-minute long respiration measurement. The average of these initial and final temperature measurements was used in statistical analyses. The respiration from each hyphal in-growth bag was measured using an infrared gas analyzer (model LI-8100, LI-COR, Lincoln, Nebraska USA) with a custom PVC chamber. The chamber was composed of two cylindrical PVC end caps with a $10 \mathrm{~cm}$ diameter. These two caps were held together by a cylindrical piece of PVC, which was $10 \mathrm{~cm}$ high. The combined thickness of the PVC connector and cap was $5 \mathrm{~mm}$. Immediately after harvest from the soil, bags were opened and emptied into the chamber, exposing the sand and hyphae to the ambient levels of $\mathrm{CO}_{2}$ in the atmosphere for 30 seconds before the respiration measurement was initiated. This allowed the relatively high $\mathrm{CO}_{2}$ concentrations of the hyphal in-growth bag environment to equilibrate with the $\mathrm{CO}_{2}$ concentrations of 
the atmosphere more quickly, increasing the accuracy of the respiration measurements (Chapter 2). The $\mathrm{CO}_{2}$ flux from each hyphal in-growth bag was measured for 10 minutes, with a 30 second deadband before the measurement began. The hyphal in-growth bag samples were then kept in plastic bags on ice until transportation to the laboratory where they were frozen at $-20^{\circ} \mathrm{C}$. Respiration measurements were available for hyphal in-growth bags from 5 control, 7 moisture addition, 9 heated and 8 combined heat and moisture addition treatment samples in 2011. In 2012 respiration measurements were available for hyphal in-growth bags from 14 control, 15 moisture addition, 12 heated and 13 combined heat and moisture addition treatment samples.

Blank hyphal in-growth bags were placed in the soil after the sample bags were removed. This was done in order to ensure that the hyphal in-growth bag method was working properly. The moisture content of the blank bags was matched to the moisture content of the sample bag that was removed to account for any differences of $\mathrm{CO}_{2}$ diffusivity caused by moisture content within the bag. The blank hyphal in-growth bags were left in the soil for 24 hours and then respiration was measured as described above. Blank hyphal in-growth bags did not contain any measureable amount of biomass, either fungal or bacterial. The flux at the final 100 $\mathrm{s}$ of measurement was recorded for both blank and sample bags. Based on data from the blank bag measurements in 2011 the $\mathrm{CO}_{2}$ flux for the final 100s was correlated with the final $\mathrm{CO}_{2}$ concentration via a linear regression $\left(\mathrm{r}^{2}=0.56\right)$. The equation $\mathrm{CO}_{2}$ Flux $=0.26$ (Final $\mathrm{CO}_{2}$ Concentration) +15.2 was used as a blank correction for the sample bag flux.

The filter flotation method was followed to remove the hyphal biomass from the hyphal in-growth bag sand (Staddon et al. 1999). Sand was poured into a $2 \mathrm{~L}$ beaker and water was washed over the surface of the mesh bag to remove any residual hyphae. Approximately $500 \mathrm{~mL}$ of water was added to the beaker and the sand and water mixture was stirred vigorously. The water was then poured over a glass fiber filter (GE Whatman 934-AH), which was prewashed and combusted, dried and weighed. The hyphae float in the water and are removed by pouring the 
water over the filter. This process was repeated three times. Filters were dried at $50^{\circ} \mathrm{C}$ for 24 hours and then placed in a desiccator for 12 hours before being weighed. Filters were then muffled at $500^{\circ} \mathrm{C}$ for 12 hours to measure loss on ignition. Due to the inherently sticky nature of fungal hyphae, sand grains from the hyphal in-growth bag often stick to the hyphal biomass that is removed by filter flotation. The sand grains do not combust, so the mass of these sand grains and the mass of the fungal hyphae can be estimated using loss on ignition.

Phospholipid fatty acid (PFLA) analyses were performed on subsamples from the sand substrate of the hyphal in-growth bags from 2011 to test whether the majority of biomass in the hyphal in-growth bags was fungal, and to determine what proportion of the biomass was from AMF. Approximately $5 \mathrm{~g}$ of sand was used for PLFA analyses. PLFA analyses were carried out according to Frostegård et al. (1991). Briefly, cells were lysed with chloroform and methanol and total lipids were extracted in the chloroform layer. Phospholipid, glycolipid and neutral lipid fractions were separated with silicic acid chromatography. Phospholipids were then methylated and the length and structures of the resulting fatty acid methyl ester chains and their relative abundances were quantified using a gas chromatograph with a flame ionization detector (Agilent 6850). The amount of phospholipid fatty acid methyl esters was used to estimate biomass for bacteria and fungi. To estimate bacterial biomass the following fatty acids were used: 14:0, iso15:0, a15:0, 16:107,

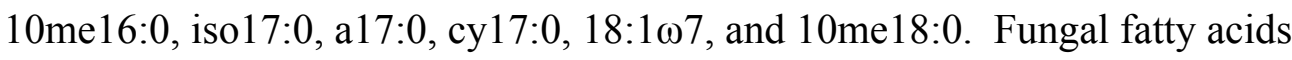
included $16: 1 \omega 5,18: 2 \omega 6,18: 1 \omega 9$, and 20:4 $\omega 6,9$. The fatty acid $16: 1 \omega 5$ is considered specific to AMF (Olsson et al. 1995).

RStudio version 0.97.511 (www.rstudio.com) was used to perform statistical analyses using the aov and $\mathrm{lm}$ functions from the stats package, and SPSS statistics 21.0 was used to make figures. Data and residuals were tested for normality, and were normally distributed. Repeated measures analysis of variance (ANOVA) tests were used to test treatment effects on fungal biomass, flux per hyphal in-growth bag and respiration per unit fungal biomass (hereafter referred to as biomass-specific respiration) for each treatment in 2011 and 2012. Block was used as a term in the 
ANOVA to account for any natural variation among blocks. Interactions between temperature and moisture were also analyzed. Multiple linear regression analyses were used to determine correlations between hyphal in-growth bag temperature and moisture content, and the biomass and respiration measurements. Alpha was set at 0.05 and $p$-values $<0.1$ and $>0.05$ were considered marginally significant.

\subsection{Results}

Year of sampling had a significant impact on hyphal biomass and biomass specific respiration (Table 3.1). Mean hyphal biomass was approximately $33 \%$ greater in 2012 than 2011 ( $P=0.038$, Figure 3.1). Mean biomass specific respiration was approximately 66\% lower in 2012 versus $2011(P<0.001$, Figure 3.3). Biomass specific respiration also showed a significant year by moisture addition treatment interaction ( $P=0.037$, Figure 3.3). Block did not have a significant effect on any of the measured variables. Heated treatments had lower flux per hyphal in-growth bag versus unheated treatments $(\mathrm{P}=0.024$, Figure 3.2$)$, and there was a significant year by heat treatment interaction $(P=0.045)$. In 2011, the drought year, $\mathrm{CO}_{2}$ flux per hyphal in-growth bag was approximately $30 \%$ lower in heated versus unheated treatments. There was a non-significant trend towards lower hyphal biomass in all of the experimental treatments versus the control in 2011.

The average temperature of hyphal in-growth bags was $22.6^{\circ} \mathrm{C}$ for heated plots and $18.8^{\circ} \mathrm{C}$ for unheated plots in 2011 . The average temperature of hyphal ingrowth bags was $22.2^{\circ} \mathrm{C}$ for heated plots and $18.8^{\circ} \mathrm{C}$ in 2012 . The average hyphal in-growth bag moisture content was $1.65 \mathrm{~g}$ for plots lacking moisture addition and $3.21 \mathrm{~g}$ for plots with moisture addition in 2011. The average hyphal in-growth bag moisture content was $2.22 \mathrm{~g}$ for plots lacking moisture addition and $4.43 \mathrm{~g}$ for plots with moisture addition in 2011. None of the multiple regression analyses showed a significant impact of temperature or moisture on biomass, $\mathrm{CO}_{2}$ flux per bag or biomass specific respiration (Tables 3.2 and 3.3).

The PLFA analyses on the sand subsamples from 2011 indicate that the primary organism growing into the hyphal in-growth bags in this system are AMF. The average ratio of fungal to bacterial markers in the sand is approximately 6:1. 
The amount of 16:1 155 is more abundant than the other fungal markers combined, accounting for an average of $65.4 \%$ of the total PLFAs, and $76.6 \%$ of the fungal PLFA markers (Table 3.4). There were no significant differences in any PLFA marker or groups of markers between different treatments.

\subsection{Discussion}

Year of sampling had the dominant impact on AMF growth and respiration. AMF biomass was significantly lower in 2011 than 2012, and biomass specific respiration was significantly greater in 2011 versus 2012 . This may be attributed to dry conditions in the early fall of 2011. Biomass specific respiration showed a significant interaction between year and moisture addition treatment, perhaps driven by significantly higher biomass-specific respiration in moisture addition plots versus plots lacking moisture addition in 2011. This result support our hypothesis that biomass specific respiration would be higher in plots with moisture addition, which is only evident in the drought year of 2011. It has been demonstrated that there is more hyphal turn-over and death during the dry season than in the wet season in a Mediterranean ecosystem (Allen and Kitajima 2013). It is possible that AMF hyphae in this study died due to lack of moisture in 2011, causing artificially inflated rates of biomass specific respiration due to $\mathrm{CO}_{2}$ flux from other microorganisms as fungal hyphae were decomposed.

We found that hyphal respiration at the bag level was higher in heated versus unheated treatments, supporting our hypothesis that fungal respiration would be higher in heated treatments compared to unheated treatments. Since ANOVA results show that there was a significant impact of heat treatment on $\mathrm{CO}_{2}$ flux per hyphal ingrowth bag, it is possible that the AMF in the heated treatments had a decreased metabolic capacity versus those in the unheated treatments. This could be caused by a change in the physiology of the fungi or the amount of $\mathrm{C}$ allocated to the AMF by the host plant. Nitrogen was cycled more rapidly in the heated plots versus the unheated plots (Jarvi and Burton 2013). If more nitrogen was available to the plant roots, the roots may not have allocated more $\mathrm{C}$ to the AMF to capture these labile nutrients for growth, leading to more active hyphae and greater respiration at the in- 
growth bag level. Roots also exhibited higher respiration rates in heated versus unheated plots in 2011 (Jarvi and Burton 2013).

The results of the ANOVA analysis indicate a significant year by moisture treatment effect on biomass specific respiration. Moisture was added with precipitation events in order to mimic natural drought cycles. It is therefore not surprising that the moisture addition plots had higher respiration than control plots in 2011. However, when no drought was present in 2012, the biomass-specific respiration was not significantly different between moisture addition plots and plots lacking moisture addition. These findings suggest that the impact of soil moisture on AMF growth and respiration may be highly dependent on disturbance history.

Using unpublished soil respiration data from Burton et al. we compared the respiration per hyphal in-growth bag to total soil respiration by scaling respiration of the $75 \mathrm{~cm}^{3}$ hyphal in-growth bag up to a soil area of $1 \mathrm{~m}^{2}$ to a $5 \mathrm{~cm}$ depth. We assumed that the respiration of hyphal in-growth bags buried at $5 \mathrm{~cm}$ depth was representative of hyphal respiration in the top $5 \mathrm{~cm}$ of soil. We also assumed that soil respiration is mostly a function of activity in the top $5 \mathrm{~cm}$ of soil. In 2011, the contribution of AMF respiration to total soil respiration was approximately $89.7 \%$ for heated plots and $126 \%$ for plots with heat and moisture addition. The contribution of AMF respiration to soil respiration was approximately $183 \%$ in moisture addition plots and $253 \%$ in control plots in 2011. In 2012, the contribution of AMF respiration to total soil respiration was approximately $42.4 \%$ for heated plots and $44.0 \%$ in plots with heat and moisture addition. The contribution of AMF respiration to soil respiration was approximately $36.6 \%$ in moisture addition plots and $41.9 \%$ for control plots in 2012 . These estimates are much greater than previously reported estimates for AMF contribution to soil respiration, which are around 6\% (Moyano 2008).

A variety of methodological artifacts associated with the hyphal in-growth bags could contribute to unreliable estimates of AMF respiration. It is possible that AMF increase respiration after being detached from the roots of host plants in the soil that provide sugar resources to the fungi as a stress response. Given that the 
sand substrate within the bag is artificial growth medium, free of organic matter before deployment and with slower rates of moisture and nutrient diffusion, AMF hyphae may establish more slowly in the bag environment. The metabolic rates of hyphae growing in the bag may be elevated compared to hyphae growing in the soil environment because hyphae in the bag may be more actively seeking nutrients. Additionally, turnover of AMF biomass within the bag may provide an organic nutrient source for free-living heterotrophs, which would lead to overestimates of the hyphal contribution to soil respiration. These results are greater than the estimates for the hyphal contribution to soil respiration found in Chapter 3, from the mixed mycorrhizal community at Harvard Forest, suggesting that AMF may not use carbon as efficiently as other types of fungi.

It is important to consider the time frame of this study in relation to the lifespan of AMF hyphae. AMF hyphae may be able to adjust respiration quickly in response to changes in soil temperature. Heinemeyer et al. (2006) found that the respiration of existing AMF hyphae adjusted to higher temperatures after two weeks of $+6^{\circ} \mathrm{C}$ warming by decreasing respiration. The production of new hyphal biomass may occur in a short time frame if new tissues are produced to increase metabolic efficiency. The ideal length of time to incubate hyphal in-growth bags in the ground is debatable. One study found that AMF hyphae can turn over in as little as one week (Staddon et al. 2003), however it is possible that these findings represent respiration of labeled $\mathrm{C}$ rather than turnover of biomass. In a Mediterranean ecosystem, Allen and Kitajima (2013) found that the mean life span of ecotmycorrhizal fungal (EMF) hyphae was 48 days. In this study hyphal in-growth bags were incubated for 120 days. It is likely that AMF hyphal turnover is linked to the extent of summer drought in our system. It is important to leave the hyphal ingrowth bags belowground for long enough to allow AMF hyphae to colonize the bag, but not long enough for extensive hyphal turnover in the bag. Our preliminary study suggested that 60 days was too short a duration to capture a measureable amount of biomass, and that 6 months was too long, as a large amount of necromass had accumulated. In addition to misleading biomass estimates, necromass within the 
bag can give heterotrophic organisms the opportunity to colonize the in-growth bag, leading to artificially high AMF hyphal respiration measurements. Our PLFA results suggest that microbial biomass in the bag environment was dominated by AMF. A study conducted in a similar forest type also found that the PLFA marker for AMF dominated the hyphal in-growth bag environment after 3 months of hyphal in-growth bag deployment (Van Diepen 2008).

The relatively high 16:1 155 fatty acid content of the sand ( $\sim 65.4 \%)$ supports our conclusion that AMF dominate hyphal in-growth bags in these soils. Other fungi present in the bag environment may have been EMF or saprotrophic fungi. There are some EMF host plants near the plots such as Tsuga canadensis and Tilia americana, and it is likely that a portion of the root systems of these plants expands into the plot boundaries. The ground flora is primarily composed of plants that have AMF mycorrhizae. Relatively little of the total fatty acid content $(\sim 14.5 \%)$ was attributed to bacteria or actinomycetes. This reinforces the concept that most of the hyphal biomass and respiration from the in-growth bags was of AMF origin.

PLFA concentrations are an index of the carbon contained in microbial biomass or various groups of microorganisms. Although PLFA concentrations are often used to measure microbial biomass they do not always correlate directly with other common measures of microbial biomass such as chloroform fumigation extractions, DNA extractions, substrate induced respiration, FDA staining and ergosterol concentrations for fungi (Bailey et al. 2002, Gaspar et al. 2001, Klamer and Bååth 2004, Olsson et al. 2003, Bååth and Anderson 2003, Landeweert et al. 2003). There are direct conversions from PLFA concentrations to biomass for only four AMF species (Gavito and Olsson 2008, Olsson et al. 1995). The soil environment contains a large number of species of AMF, all with different cell structure and growth habits. Most of these AMF species have not been grown in laboratory conditions, and thus there are no reliable estimates for PLFA to biomass conversions. Due to these limitations we did not attempt to convert the PLFA concentrations to microbial biomass. 


\subsection{Conclusion}

In conclusion we have found that seasonal drought may have a large impact on AMF growth and respiration. AMF biomass production responds negatively to drought, but the impact of drought on AMF respiration remains unclear. Biomass specific respiration of fungal hyphae may increase in response to drought. This is concerning since the frequency of drought may increase with climate change (Meehl et al. 2007). Greater drought frequency, in combination with higher soil temperatures, could lead to lower AMF contribution to soil respiration when averaged over long time periods, indicated by a lower contribution of fungal hyphae to total soil respiration in heated plots in 2011 during a seasonal drought versus 2012. There may be other resources, which limit the growth and respiration of AMF overtime, such as soil nutrient supply. High amounts of available soil $\mathrm{N}$ can cause lower AMF abundance (Van Diepen 2008). The hyphal in-growth bag method is an appropriate approach to capture AMF hyphae in isolation from other soil organisms. It is necessary to conduct preliminary analyses to determine the proper time frame to deploy hyphal in-growth bags in the soil in order to obtain a sufficient amount of biomass for accurate respiration measurements and avoid hyphal turnover in the bag environment. The hyphal in-growth bag method may misrepresent the contribution of fungal hyphae to total soil respiration. More research both in controlled mesocosms and field studies will help to strengthen these methods and add to our understanding of climate change impacts on ecosystem functioning. 
Table 3.1. Results of repeated measures analysis of variance for hyphal biomass (g), $\mathrm{CO}_{2}$ flux per hyphal in-growth bag ( $\mu \mathrm{mol} \mathrm{CO}_{2} /$ hyphal in-growth bag/s), and biomass-specific respiration ( $\mu \mathrm{mol} \mathrm{CO} / \mathrm{g}$ hyphae/s). F-values with 2 and 36 degrees of freedom are shown. Significance at alpha $=0.05$ is indicated by $*$, significance at alpha $=0.01$ are indicated by $* *$ and significance at alpha $<0.001$ are indicated by $* * *$.

\begin{tabular}{llll} 
& Biomass & $\begin{array}{l}\text { Flux per Hyphal } \\
\text { In-growth Bag }\end{array}$ & $\begin{array}{l}\text { Biomass- } \\
\text { Specific } \\
\text { Respiration }\end{array}$ \\
Year & $4.50^{*}$ & 0.580 & $27.1^{* * *}$ \\
\hline Block & 1.06 & 0.014 & 0.339 \\
\hline Heat & 0.245 & $4.17^{*}$ & 0.024 \\
\hline Moisture & 0.011 & 0.401 & 0.935 \\
\hline Heat x Moisture & 0.377 & 2.04 & 0.433 \\
\hline Moat x Year & 0.508 & $4.20^{*}$ & 0.244 \\
\hline Heat x Moisture x Year & 0.097 & 0.077 & $4.54^{*}$ \\
\hline
\end{tabular}

Table 3.2 Results of the regression analysis for moisture content and temperature effects on hyphal biomass ( $\mathrm{g}$ ), $\mathrm{CO}_{2}$ flux per hyphal in-growth bag ( $\mu \mathrm{mol} \mathrm{CO}_{2} /$ hyphal in-growth bag/s), and biomass-specific respiration ( $\mu \mathrm{mol} \mathrm{CO} / \mathrm{g}$ hyphae/s) in 2011. F-values for the correlation have 2 and 36 degrees of freedom. Significance at alpha $=0.05$ is indicated by *

\begin{tabular}{lll} 
Equation & $\mathrm{r}^{2}$ & $\mathrm{~F}$-value \\
$\begin{array}{l}\text { biomass }=0.017+0.022(\text { moisture)-0.0001(temperature)- } \\
\text { 0.0009(moisture*temperature) }\end{array}$ & 0.005 & 0.174 \\
\hline $\begin{array}{l}\text { CO } \mathrm{O}_{2} \text { flux }=0.014-0.0002(\text { moisture)- } \\
\text { 0.0003(temperature)+0.0005(moisture*temperature) }\end{array}$ & 0.038 & 0.392 \\
\hline $\begin{array}{l}\text { biomass-Specific respiration= 12.4-0.0087(moisture } \\
\text { content)-0.382(temperature)-0.0002(moisture*temperature) }\end{array}$ & 0.063 & 0.258 \\
\hline
\end{tabular}


Table 3.3 Results of the regression analysis for moisture content and temperature effects on hyphal biomass $(\mathrm{g}), \mathrm{CO}_{2}$ flux per hyphal in-growth bag ( $\mu \mathrm{mol} \mathrm{CO}_{2} /$ hyphal in-growth bag/s), and biomass-specific respiration ( $\mu \mathrm{mol} \mathrm{CO}_{2} / \mathrm{g}$ hyphae/s) in 2012. F-values for the correlation have 2 and 36 degrees of freedom. Significance at alpha $=0.05$ is indicated by *.

\begin{tabular}{|c|c|c|}
\hline Equation & $r^{2}$ & F-value \\
\hline $\begin{array}{l}\text { biomass }=0.022-0.001 \text { (moisture)-0.00001(temperature)- } \\
0.0002 \text { (moisture*temperature) }\end{array}$ & 0.003 & 0.087 \\
\hline $\begin{array}{l}\mathrm{CO}_{2} \text { flux }=-0.039+0.073 \text { (moisture) }+0.002 \text { (temperature)- } \\
0.004 \text { (moisture }{ }^{*} \text { temperature) }\end{array}$ & 0.074 & 0.077 \\
\hline $\begin{array}{l}\text { biomass-specific respiration }=-2.46+0.636 \text { (moisture } \\
\text { content })+0.092(\text { temperature })-0.081 \text { (moisture } * \text { temperatt }\end{array}$ & 0.028 & 0.192 \\
\hline
\end{tabular}

Table 3.4 Results of the PLFA analyses hyphal in-growth bag sand. PLFA quantities are given in nmol PLFA per g sand. There were no significant differences between treatments for any individual PLFA marker, or groups of PLFA makers

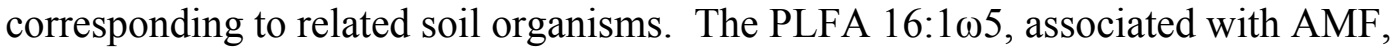
dominated the PLFA profiles.

\begin{tabular}{llllll} 
& Control & Heated & $\begin{array}{l}\text { Moisture } \\
\text { Addition }\end{array}$ & $\begin{array}{l}\text { Heated \& } \\
\text { Moisture } \\
\text { Addition }\end{array}$ & Average \\
$\begin{array}{l}\text { Bacterial } \\
\text { PLFA }\end{array}$ & 0.563 & 0.632 & 0.528 & 0.590 & 0.578 \\
\hline $\begin{array}{l}\text { Fungal } \\
\text { PLFA }\end{array}$ & 3.29 & 3.49 & 3.53 & 3.36 & 3.42 \\
\hline Total PLFA & 3.85 & 4.12 & 4.06 & 3.95 & 3.99 \\
\hline \% Bacteria & 14.6 & 15.4 & 13.0 & 14.9 & 14.5 \\
\hline \% Fungi & 85.4 & 84.7 & 86.1 & 85.1 & 85.5 \\
\hline F:B & $\sim 6: 1$ & $\sim 6: 1$ & $\sim 6: 1$ & $\sim 6: 1$ & $\sim 6: 1$ \\
\hline AMF PLFA & 2.44 & 2.53 & 2.87 & 2.62 & 2.61 \\
\hline $\begin{array}{l}\text { \% AMF } \\
\text { PLFA }\end{array}$ & 63.2 & 61.4 & 70.8 & 66.3 & 65.4 \\
\hline $\begin{array}{l}\text { \% AMF of } \\
\text { Total }\end{array}$ & 74.0 & 72.5 & 82.2 & 77.9 & 76.5 \\
\hline
\end{tabular}

Total

Fungal 


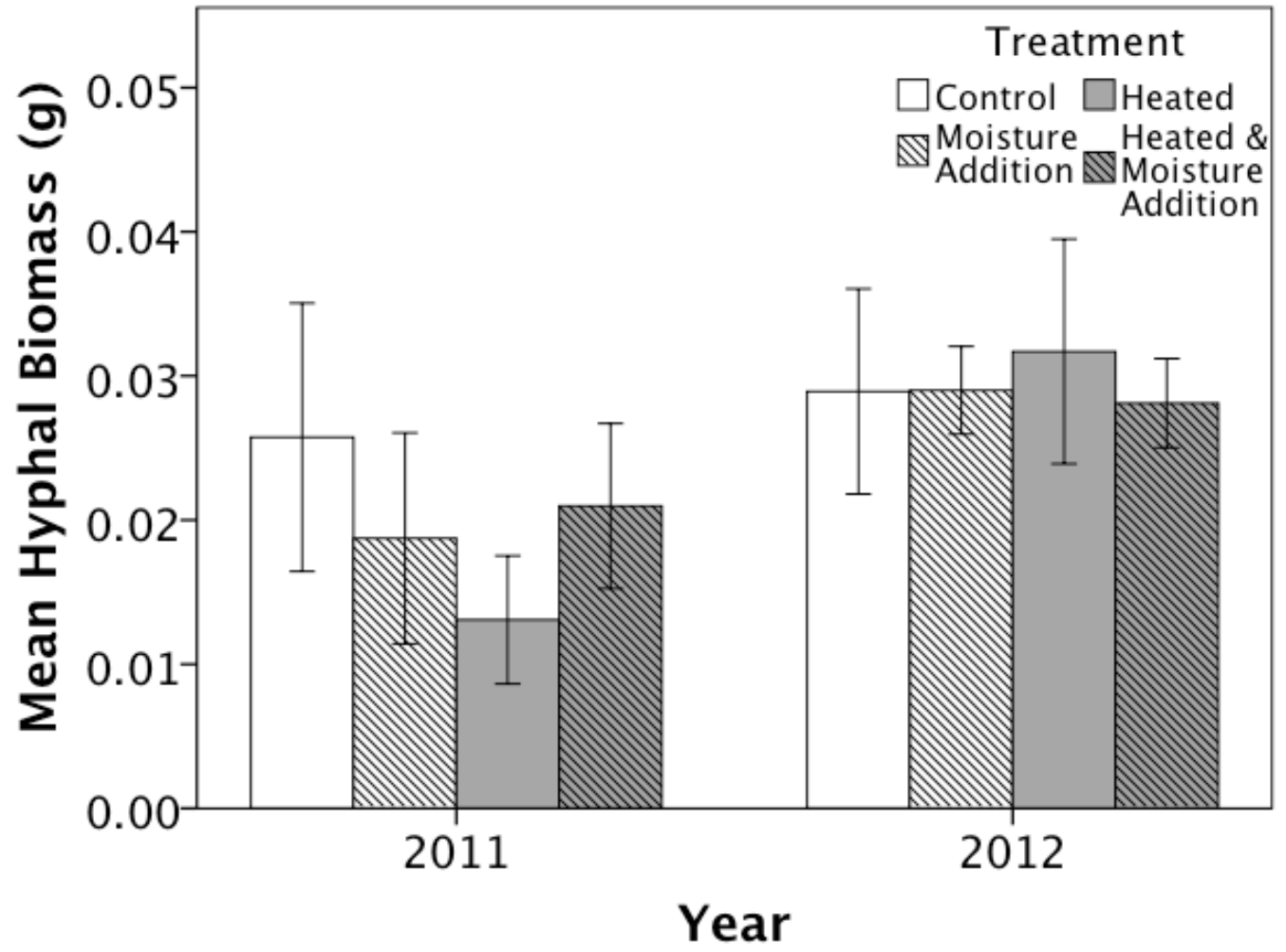

Figure 3.1. Mean hyphal biomass (g) for each year by treatment. There was a significant effect of year on hyphal biomass; with lower hyphal biomass is 2011 than 2012. There were no significant treatment effects on biomass. Error bars are one standard error of the mean. 


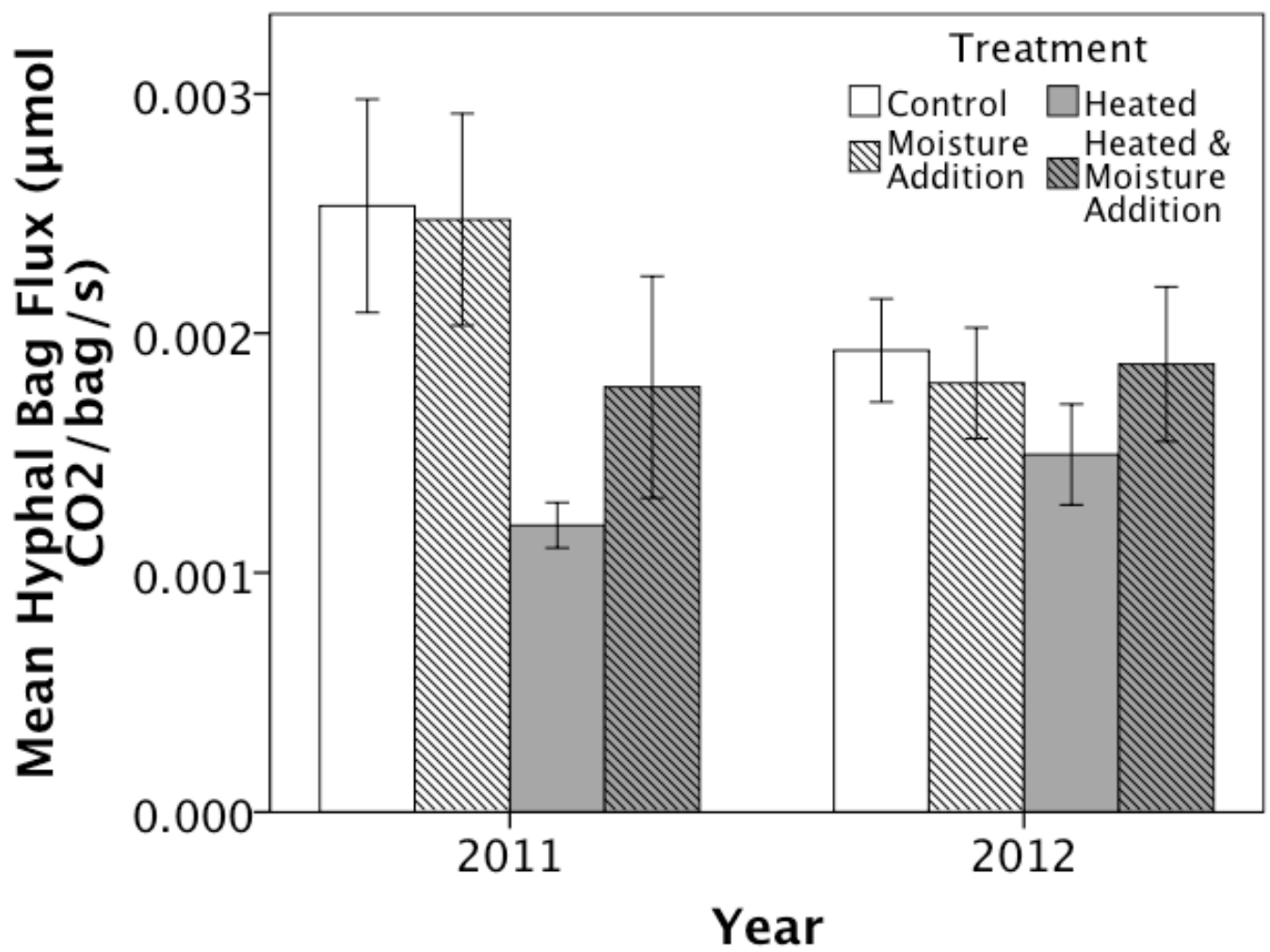

Figure 3.2 Mean $\mathrm{CO}_{2}$ flux per hyphal in-growth bag ( $\mu$ mol $\mathrm{CO}_{2} /$ hyphal in-growth bag/s) for each treatment by year. Mean $\mathrm{CO}_{2}$ flux per hyphal in-growth bag was significantly lower in heated versus unheated treatments. There was also a significant heat by year interaction. Error bars are one standard error of the mean. 


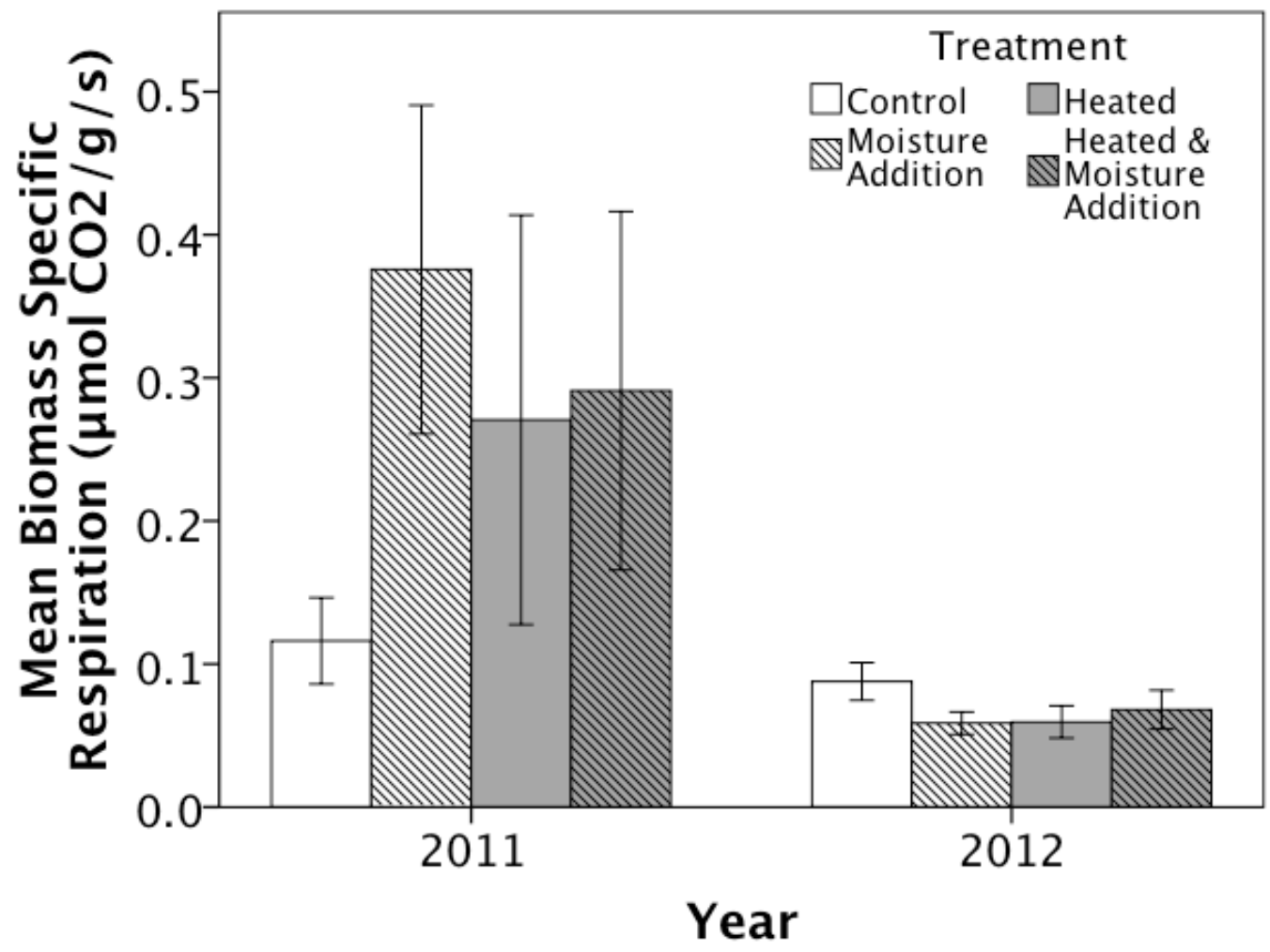

Figure 3.3 Mean biomass-specific respiration ( $\mu \mathrm{mol} \mathrm{CO}_{2} / \mathrm{g}$ hyphae/s) for each treatment by year. There was significantly lower biomass-specific respiration in 2012 versus 2011. There was also a significant interaction between year and moisture addition treatment. Error bars are one standard error of the mean. 


\subsection{References}

Addy, H.D., Schaffer, G.F., Miller, M.H. and R.L. Peterson. 1994. Survival of the external mycelium of a VAM fungus in frozen soil over winter. Mycorrhiza. 5(1):15 .

Allen, M.F. and K. Kitajima. 2013. In situ high-frequency observations of mycorrhizas. New Phytologist. 200: 222-228.

Atkin, O.K., and M.G. Tjoelker. 2003. Thermal acclimation and the dynamic response of plant respiration to temperature. TRENDS in Plant Science. 8(7): 343351.

Atkin, O.K., Sherlock, D., Fitter, A.H., Jarvis, S., Hughes, J.K., Campbell, C., Hurry, V. and A. Hodge. 2008. Temperature dependence of respiration in roots colonized by arbuscular mycorrhizal fungi. New Phytologist. 1-12.

Bååth, E. and T.H. Anderson. 2003. Comparison of soil fungal/bacterial ratios in a $\mathrm{pH}$ gradient using physiological and PLFA-based techniques. Soil Biology \& Biochemistry. 35: 955-963.

Bailey, V.L., Peacock, A.D., Smith, J.L. and H. Bolton. 2002. Relationships between soil microbial biomass determined by chloroform fumigation-extraction, substrate-induced respiration, and phospholipid fatty acid analysis. Soil Biology \& Biochemistry. 34: 1385-1389.

Bass, R., van der Werf A., and Lambers H. 1989. Root respiration and growth in Plantago major as affected by vesicular-arbuscular mycorrhizal infection. Plant Physiology 91: 227-232.

Bradford, M.A., Davies, C.A., Frey, S.D., Maddox, T.R., Melillo, J.M., Mohan, J.E., Reynolds, J.F. and K.K. Treseder. 2008. Thermal adaptation of soil microbial respiration to elevated temperatures. Ecology Letters. 11: 1316-1327.

Frostegård, A., Tunlid, A. and E. Bååth. 1991. Microbial biomass measured as total lipid phosphate in soils of different organic content. Journal of Microbiological Methods. 14: 151-163.

Gaspar, M.L., Cabello, M.N., Pollero, R. and M.A. Aon. 2001. Fluorescein diacetate hydrolysis as a measure of fungal biomass in soil. Current Microbiology. 42: 339-344. 
Gavito, M.E. and P.A. Olsson. 2008. Foraging strategies of the external mycelium of the Arbuscular mycorrhizal fungi Glomus intraradices and Scuttellospora calospora. Applied Soil Ecology. 39: 282-290.

Grimoldi, A.A., Kavanová, M., Lattanzi, F.A., Schäufele, R. and H. Schnyder. 2006. Arbuscular mycorrhizal colonization on carbon economy in perennial ryegrass: quantification by $13 \mathrm{CO}_{2} / 12 \mathrm{CO} 2$ steady-state labeling and gas exchange. New Phytologist. 172: 544-553.

Hawkes, C.V., Hartley, I.P., Ineson, P. and A.H. Fitter. 2008. Soil temperature affects carbon allocation within arbuscular mycorrhizal networks and carbon transport from plant to fungus. Global Change Biology. 14: 1181-1190.

Heinemeyer, A., Ineson, P., Ostle, N. and A.H. Fitter. 2006. Respiration of the external mycelium in the arbuscular mycorrhizal symbiosis shows strong dependence on recent photosynthates and acclimation to temperature. New Phytologist. 171, 159-170.

Jarvi, M.P. and A.J. Burton. 2013. Acclimation and soil moisture constrain sugar maple root respiration in experimentally warmed soil. Tree Physiology. 33: 949959.

Klamer, M. and E. Bååth. 2004. Estimation of conversion factors for fungal biomass determination in compost using ergosterol and PLFA 18:2w6,9. Soil Biology \& Biochemistry. 36: 57-65.

Landeweert, R., Veenman, C., Kuyper, T.W., Fritze, H., Wernars, K. and E. Smit. 2003. Quantification of ectomycorrhizal mycelium in soil by real-time PCR compared to conventional quantification techniques. FEMS Microbial Ecology. 45: 283-292.

Luo et al. 2001 Luo, Y., Wan, S., Hui, D., Wallace, L.L., 2001. Acclimatization of soil respiration to warming in a tall grass prairie. Nature. 413: 622-624.

Meehl, G. A. et al. In: Climate Change 2007: The Physical Science Basis. Contribution of Working Group I to the Fourth Assessment Report of the Intergovernmental Panel on Climate Change. Solomon, S. et al. (eds.). Cambridge University Press: New York, New York, USA.

Melillo, J.M., Steudler, P.A., Aber, J.D., Newkirk, K., Lux, H., Bowles, F.P., Catricala, C., Magill, A., Ahrens, T. and S. Morrisseau. 2002. Soil warming and carbon-cycle feebacks to the climate system. Science. 298: 2173-2165. 
Moyano, F. E. 2008. Dissertation. Soil Respiration Fluxes and Controlling Factors in Temperate Forest and Cropland Ecosystems.

Nielsen, K.L., Bouma, T.J., Lynch, J.P., and D.M. Eissenstat. 1998. Effects of phosphorus availability and vesicular-arbuscular mycorrhizas on the carbon budget of common bean (Phaseolus vulgaris). New Phytologist. 139: 647-656.

Oechel, W.C., Vourlitis, G.L., Hastings, S.J., Zulueta, R.C., Hinzman, L., Kane, D., 2000. Acclimation of ecosystem CO2 exchange in the Alaskan Artic in response to decadal climate warming. Nature. 406: 978-981.

Olsson, P.A., Bååth, E., Jakobsen, I. and B. Söderström. 1995. The use of phospholipid and neutral lipid fatty acids to estimate biomass of arbuscular mycorrhizal fungi in soil. Mycological Research. 99: 623-629.

Olsson, P.A. Larsson, L., Bago, B., Wallander, H. and I. M. van Aarle. 2003. Ergosterol and fatty acids for biomass estimation of mycorrhizal fungi. New Phytologist. 159: 7-10.

Pearson, J.N. and I. Jakobsen. 1993. Symbiotic exchange of carbon and phosphorus between cucumber and three arbuscular mycorrhizal fungi. New Phytologist. 124: 481-488.

Peng, S., Eissenstat, D.M., Graham, J.H., Williams, K., and N.C. Hodge. 1993. Growth depression in mycorrhizal citrus at high phosphorus supply. Plant Physiology. 101: 1063-1071.

Schüßler, A., Schwarzott, D. and C. Walker. 2001. A new fungal phylum, the Glomeromycota: phylogeny and evolution. Mycological Research. 105: 14131421.

Smith, S.E. and D.J. Read. 2008. Mycorrhial Symbiosis, Third Edition. Academic press, Elsevier. London, UK.

Staddon, P.L., Fitter, A.H., and J.D. Graves. 1999. Effect of elevated atmospheric $\mathrm{CO}_{2}$ on mycorrhizal colonization, external mycorrhizal hyphal production and phosphorus inflow in Plantago laneolata and Trifolium repens in association with the arbuscular mycorrhizal fungus Glomus mosseae. Global Change Biology. 5: 347-358.

Staddon, P.L., Ramsey, C.B., Ostle, N., Ineson, P., and A.H. Fitter. 2003. Rapid turnover of hyphae of mycorrhizal fungi determined by AMS microanalysis of 14C. Science. 300: 1138-1140. 
Van Diepen, L. 2008. The role and diversity of arbuscular mycorrhizal fungi in Acer saccharum dominated forest ecosystems under natural and $\mathrm{N}$-amended conditions. Michigan Technological University, Ph.D. dissertation.

Wright, D.P., Scholes, J.D., and D.J. Read. 1998. Mycorrhizal sink strength influences whole plant carbon balance of Trifolium repens L. Plant, Cell \& Environment. 21: 881-891. 


\section{Chapter 4: Climate Change Study on Soil Extracellular Enzyme Activity Responds More Strongly to Drought than Soil Warming ${ }^{3}$}

\subsection{Abstract}

The impact of climate change on soil extracellular enzyme activity has not been studied in great detail in northern temperate forests. Many studies that have examined the impact of soil warming on enzyme activities in other ecosystems have had lower soil moisture in heated plots compared to unheated plots. This makes it difficult to parse apart the impact of warming versus drying of the soil on enzyme activity. Additionally, few published studies have examined temporal variation in enzyme activities. To address these gaps in knowledge the study presented here used a fully factorial $2 \times 2$ soil warming $\left(+4-5^{\circ} \mathrm{C}\right)$ and moisture addition $(+30 \%$ average ambient growing season precipitation) experiment to examine changes in enzyme activity over the course of the 2011 growing season. All enzyme activity differed significantly by month of sampling, likely due to low moisture content when severe drought occurred during August and September. When measured at relevant treatment temperature $\left(15^{\circ} \mathrm{C}\right.$ for unheated plots and $20^{\circ} \mathrm{C}$ for heated plots) the activities of cellobiosidase, $\beta$-glucosidase, NAGase and phenol oxidase were higher in heated versus unheated treatments, supporting our hypothesis that soil warming would increase enzyme activity. NAGase and acid phosphatase activity showed significant effects of moisture at the $20^{\circ} \mathrm{C}$ measurement temperature. Enzyme activity was typically greater in plots receiving moisture addition compared to plots without moisture addition, supporting our hypothesis that higher soil moisture content would increase the production of enzymes. Further investigations into the

\footnotetext{
${ }^{3}$ Chapters $4 \& 5$ will be merged into a single article for publication in the journal Soil Biology and Biochemistry. Data from Chapter 6 will be used in this publication. The figures and text will be reformatted before submission. The order of authors for this article will be Carley Kratz, Erik Lilleskov and Andrew Burton. Carley Kratz, Andrew Burton and Erik Lilleskov have all contributed to the written portion of the text. The experimental site was overseen by Andrew Burton. Carley Kratz contributed to the methodological design and was responsible for collecting and processing data.
} 
composition of organic matter in soils under treatment will help us to understand the mechanisms driving changes in enzyme activity and production.

\subsection{Introduction}

As global temperatures continue to rise and precipitation patterns change, it becomes more important to understand possible feedbacks to the climate system (Christensen et al. 2007, Meehl et al. 2007). One of these feedbacks comes from soil microorganisms as they break down organic matter, helping to make nutrients available to plants. It remains unclear how microbial metabolism is impacted by changes in temperature and moisture availability. This may be because microorganisms rely on many different types of metabolism that require various substrates. Some microbial taxa are able to shift their mode of metabolism based on environmental conditions. For example, many species of yeast are able to switch between aerobic and anaerobic metabolism. Other microorganisms rely on a single metabolic pathway and can regulate metabolic rates in response to their surroundings. Measuring the enzymatic activity of soil extracts can aid in partitioning microbial metabolism into groups based on the substrates that they metabolize.

The metabolic function of the soil microbial community as a whole relies on many different factors. One of these factors is soil moisture availability. Many climate change scenarios predict changes in the amount of precipitation, in addition to warmer temperatures. In some regions it is unclear if there will be more or less precipitation, but it is clear that weather patterns are going to change globally and regionally (Christensen et al. 2007). Temperature is another important factor regulating the activity and production of extracellular enzymes. In typical enzyme kinetics, an increase in temperature will lead to an exponential increase in the rate of enzyme catalysis. Laboratory potential enzyme assays show the potential activity of a particular enzyme because they supply ample amounts of substrate to the enzyme in order to measure the rate of activity. Under natural conditions substrate availability, or other variables such as nutrients or moisture often become limiting to the production and activity of enzymes. 
Enzyme activity assays are rare in soil warming studies and only a few different enzymes have been tested. A soil warming study in a boreal black spruce forest showed lower rates of chitinase activity at temperatures $0.5^{\circ} \mathrm{C}$ above ambient (Allison and Treseder 2008). Fungi are the only microorganisms that are known to produce substantial amounts of chitinase in the soil (Kellner et al. 2010), however in this study fungal biomass decreased dramatically even though chitinase activity only showed a marginal decrease with warming. This suggests that the production of extracellular chitinase per unit fungal biomass increased in response to warmer soil temperatures, or that chitinase activity was stabilized in the soil. Arnold et al. (1999) examined changes in microbial biomass and dehydrogenase activity due to soil warming in a spruce-fir forest and also incubated soil at $5-25^{\circ} \mathrm{C}$. Both microbial biomass and dehydrogenase activity decreased under warmer temperatures. More recently, Bell et al. (2010) studied enzyme activity in an open field soil warming experiment in a temperate grassland and found that despite seasonal trends, enzyme activity did not change with soil warming. Studies examining enzyme activity in forest soil warming studies have been conducted in coniferous forests and it remains unclear how well these results may translate to soils from deciduous forests. Clearly, there is very little data on enzyme activities from forest soil warming studies, leaving much more to be explored.

In many experimental soil-warming studies higher temperature leads to an increase in evapotranspiration, which decreases soil moisture (Luo et al. 2001, Oechel et al. 2000, Frey et al. 2008, Allison and Treseder 2008). This confounds the temperature manipulation with soil water availability. The study reported here was conducted at a research site located in northern Michigan that has both warming (+4$5{ }^{\circ} \mathrm{C}$ ) and moisture addition ( $+30 \%$ of average ambient growing season precipitation) treatments in a fully factorial design. This allowed us to test the shortterm impact of warming and soil moisture availability independently and in interaction, something that has not been done before in a field experiment in a mature forest. 
The substrates studied here included cellulobioside, $\beta$-glucoside, phosphate (under acidic soil pH), N-acetyl-glucosaminide (NAGase), and L-DOPA as a phenol surrogate. The range of enzymes tested is capable of breaking down very simple to more complex molecules in an aerobic environment. This helps relate the enzyme activity to the rate of carbon cycling for labile and recalcitrant compounds. Cellobiosidase is a hydrolytic exocellulase which cleaves the 1, 4 bond between glucose molecules that make up cellulose polymers. This produces cellulose with 2 or 4 glucose constituents. $\beta$-glucosidase is a hydrolytic exocellulase which cleaves the 1,4 bond on terminal glucose molecules that make up cellulose, releasing free glucose molecules. Acid phosphatase is a hydrolytic enzyme, which cleaves phosphate molecules from larger macromolecules. N-acetylglucosaminidase (NAGase) cleaves the 1,4 bond between the N-acetylglucosaminide molecules that make up chitin. Phenol oxidase and peroxidase are both oxidative enzymes which both alter the structure of large macromolecules, such as lignin or smaller phenolic compounds. Both require oxygen as a terminal electron acceptor, and peroxidase also requires hydrogen peroxide.

The objective of this study was to determine how the functional capacity of the soil microbial community responds to increased temperature and altered soil moisture. Soil moisture and temperature can be limiting factors in soil respiration (Yuste et al. 2007). In the short-term enzyme activity will increase as temperatures increase. The chemical transformations that are enzymatically mediated in the soil should take place more quickly in heated versus unheated treatments (Koch et al. 2007). We expected that moisture addition would also positively impact the activity of each enzyme. Higher moisture and temperature should generally have a positive impact on the diffusion of both substrates and enzymes in the soil (Allison 2005), although the impact of diffusion may not be as great for membrane bound enzymes or polymeric substrates compared to exoenzymes and monomeric substrates. If higher diffusivity of substrates leads to more production of enzymes, we would anticipate greater potential activity when diffusion is highest. A more accurate estimation of how the soil microorganisms change metabolically in response to soil 
warming and changes in moisture availability will enhance our understanding of the role that soil microorganisms play in carbon and nutrient cycling.

\subsection{Methods}

A climate change manipulation experiment was initiated in September 2010 at the Ford Forestry Center in the Upper Peninsula of Michigan. This hardwood forest has been managed for Acer saccharum Marsh. timber production and has not been thinned for over a decade. Michigan Technological University's Ford Forestry Center is located at $46^{\circ} 38^{\prime} 26^{\prime \prime} \mathrm{N} 88^{\circ} 29^{\prime} 01^{\prime \prime} \mathrm{W}$ and $\sim 400$ m elevation. Mean annual temperature in the area is $4.9^{\circ} \mathrm{C}$, with a growing season (May through September) average temperature of $15^{\circ} \mathrm{C}$. The area receives on average $879 \mathrm{~mm}$ of precipitation annually, with $401 \mathrm{~mm}$ of precipitation falling during the growing season (Burton et al. 2012). Sugar maple dominates the overstory (trees $>5.0 \mathrm{~cm}$ diameter), contributing to $89 \%$ of the overstory basal area. American elm (Ulmus americana L.), eastern hemlock (Tsuga canadensis (L.) Carr.), ironwood (Ostrya virginiana (Mill.) K. Koch) and yellow birch (Betula alleghaniensis Britton) comprise the remainder. Soils are Kallio cobbly silt loams (Coarse-loamy, mixed, superactive, frigid Oxyaquic Fragiorthods).

The experiment has a full factorial design with three blocks under the following treatment combinations; a control under ambient conditions, soil heating $\left(+4-5{ }^{\circ} \mathrm{C}\right)$, moisture addition $(+30 \%$ of average ambient growing season precipitation) and soil heating plus moisture addition. There are three $10 \mathrm{~m} \times 10 \mathrm{~m}$ plots per treatment with no replication within a block. The level of warming and moisture addition is in accordance with current climate models (Christensen et al. 2007). Warming was accomplished via infrared lamps suspended $1.5 \mathrm{~m}$ above the soil surface. The moisture addition represents the upper limit of potential precipitation predicted by IPCC models (Christensen et al. 2007), and should replace most of the evaporative loss associated with the elevated temperature during the majority of the growing season. Precipitation was gathered in large tanks and distributed onto plots using a sprinkler system during rain events, when possible, in order to mimic natural rainfall patterns. 
Enzyme assays were conducted on slurries from soils collected once per month from the Ford Forestry Center experiment during the growing season from April to October 2011. On each assay date five soil cores of $1 \mathrm{~cm}$ diameter and 10 $\mathrm{cm}$ depth were collected from each plot; one sample from near each corner and one sample from the center of the plot. Each of these samples was treated independently during laboratory analyses resulting in 15 samples per treatment. Soil was transported in plastic bags on ice from the field to the laboratory immediately after sampling. Enzyme assays were carried out within 12 hours of soil collection. The enzymes assays were conducted according to Sinsabaugh et al. (2005). Briefly, approximately $1 \mathrm{~g}$ of fresh soil was added to $125 \mathrm{~mL}$ of $50 \mathrm{mM}$ sodium acetate buffer $(\mathrm{pH}=5.0)$ and blended for $10 \mathrm{~s}$. Enzyme assays were carried out in a 96-well plate format, following Saiya-Cork et al. (2002). There were 16 technical replicates per sample. Each replicate contained $200 \mu \mathrm{L}$ of soil slurry and $50 \mu \mathrm{L}$ of substrate. Hydrolytic enzyme activity was estimated using $200 \mu \mathrm{M}$ fluorometric substrates including acid phosphatase, $\beta$-glucosidase, cellobiosidase and NAGase (chitinase). The hydrolytic enzyme assays included a blank with $250 \mu \mathrm{L}$ of buffer, a substrate correcting blank containing $200 \mu \mathrm{L}$ of buffer and $50 \mu \mathrm{L}$ of substrate, and a quenching blank containing $200 \mu \mathrm{L}$ of buffer and $50 \mu \mathrm{L}$ of methylumbelliferone. Each of these had 8 technical replicates per plate. Additionally, there were 8 technical replicates containing $50 \mu \mathrm{L}$ of methylumeliferone and $200 \mu \mathrm{L}$ of soil slurry for each sample to calculate the quenching coefficient. Oxidative enzyme activity was estimated using the colorimetric L-DOPA substrate method to measure phenol oxidase and peroxidase activity. There were 16 technical replicates per sample, and 8 technical replicates for blanks including $250 \mu \mathrm{L}$ of buffer, $200 \mu \mathrm{L}$ of buffer and 50 $\mu \mathrm{L}$ of $5 \mathrm{mM}$ L-DOPA substrate, and $200 \mu \mathrm{L}$ of sample slurry with $50 \mu \mathrm{L}$ of buffer. The peroxidase assays also had $10 \mu \mathrm{L}$ of $\mathrm{H}_{2} \mathrm{O}_{2}$ added to all wells. Duplicate samples were incubated at $15^{\circ} \mathrm{C}$ and $20^{\circ} \mathrm{C}$ in order to represent the average soil temperatures in the unheated and heated plots in an ecologically relevant manner (Fenner et al. 2005 ) and to permit estimation of $Q_{10}$ values. Hydrolytic enzyme samples incubated for 2 hours, and then $10 \mu \mathrm{L}$ of $1.0 \mathrm{M} \mathrm{NaOH}$ was added to each well in order to stop 
the reaction. Fluorescence was measured at an excitation of $364 \mathrm{~nm}$ and an emission wavelength of $450 \mathrm{~nm}$ using a SpectraMax M2 plate reader. Oxidative enzyme samples incubated for 24 hours and the absorbance was measured at $450 \mathrm{~nm}$. Enzyme activities were calculated according to German et al. (2011).

Statistical analyses were conducted using RStudio (www.rstudio.com). Activities were averaged at the plot level before statistical analysis, yielding three samples per treatment. Data residuals were tested for normality, and a normal distribution was found. A repeated measures ANOVA design was used using the aov function in the stats package of R. ANOVA tests were conducted with potential enzyme activity at the relevant treatment temperature, potential enzyme activity at 15 ${ }^{\circ} \mathrm{C}$, potential enzyme activity at $20^{\circ} \mathrm{C}$, and $\mathrm{Q}_{10}$ as dependent variables. Relevant treatment temperature activities included activities from the incubation at $15^{\circ} \mathrm{C}$ for unwarmed plots and $20^{\circ} \mathrm{C}$ for warmed plots. $\mathrm{Q}_{10}$ was calculated as the ratio of the $20^{\circ} \mathrm{C}$ incubation to the $15^{\circ} \mathrm{C}$ incubation, raised to the power of two $\left(\mathrm{Q}_{10}=\mathrm{R}_{2} / \mathrm{R}_{1} \wedge \wedge_{2}{ }^{\mathrm{T}}\right.$ $\left.{ }_{1}{ }^{1}\right)$. $Q_{10}$ values were not analyzed for the oxidative enzymes because there were many instances in which no activity was detected. Independent variables included treatment, block and month. The main effects of block, heat, water and interaction between heat and water were determined between subjects. Within subjects effects were tested for month, month by block interaction, month by heat interaction, month by water interaction and a three-way interaction between month, heat and water. Alpha was set at 0.05 .

\subsection{Results}

Four of the six enzymes assayed showed significant differences related to experimental heat treatments when activity was considered at the relevant measurement temperature (Table 4.1). These include cellobiosidase, $\beta$-glucosidase, NAGase and phenol oxidase. $\beta$-glucosidase activity was significantly impacted by month and was higher in heated versus unheated treatments (Figure 4.1). There was also a significant heat by month interaction. The greatest difference of $\beta$ glucosidase between heated and unheated treatments occurred in June and July where heated treatments had $50 \%$ greater activity than unheated treatments. 
Cellobiosidase, NAGase and phenol oxidase activity also showed significantly higher activity in heated versus unheated treatments (Figures 4.2, 4.3 \& 4.4). Cellobiosidase activity was approximately $40 \%$ greater in heated treatments compared to unheated treatments (Figure 4.2). NAGase activity was 15\% greater in heated versus unheated treatments (Figure 4.3). Phenol oxidase activity was 66\% greater in heated treatments compared to unheated treatments (Figure 4.4)

The activity of all enzymes assayed at relevant treatment temperature varied significantly by month. Cellobiosidase activity was greatest in April and July and relatively low in August, decreasing by approximately 66\% from July to August (Figure 4.5). $\quad \beta$-glucosidase, acid phosphatase and NAGase activities were also 50\% lower in September versus other months (Figure 4.1, 4.6 \& 4.7). Phenol oxidase activity decreased from April to September, and then had relatively high rates in in October, ranging by nearly 100\% seasonally (Figure 4.8). Peroxidase activity declined from April to June, and no activity was detected in July or August (Figure 4.9). Peroxidase activity increased again in September to October, although did not reach the same elevated activity rates that were detected in the spring.

When a repeated measures ANOVA was performed on enzyme assays at the common temperature of $15^{\circ} \mathrm{C}$ none of the enzymes assayed showed significant treatment effects (Table 4.2). All enzymes assayed showed significant variation according to month. Additionally, there were significant block and month by block effects on phenol oxidase activity (Figure 4.10). Block 1 had $66 \%$ higher activity versus other blocks in April, driving the significant block effects, and phenol oxidase activity tended to decline from April to August. Peroxidase activity decreased by nearly $100 \%$ from April to June, there was no activity from July to September, and then activity increased again in September (Figure 4.11). The activity of all four hydrolytic enzymes was lower in August relative to other months. Cellobiosidase activity decreased from April to June, increased in July, and then decreased again in August with activity levels rebounding in the September and October (Figure 4.12). Cellobiosidase activity was approximately 50\% higher in April and July compared to all other months. $\beta$-glucosidase and NAGase activities decreased from April to May 
and then increased from June to July (Figures $4.13 \& 4.14$ ). $\beta$-glucosidase and NAGase activity decreased again in August and then increased September. Over the course of the growing season, $\beta$-glucosidase and NAGase activities varied by $80 \%$. Acid phosphatase activity declined from April to August and increased by $80 \%$ from August to September (Figure 4.15).

Results of the repeated measures ANOVA on enzyme activity at the common temperature of $20^{\circ} \mathrm{C}$ showed significant effects of moisture treatment on two of the enzymes tested (Table 4.3). Acid phosphatase activity was approximately $15 \%$ greater in treatments with moisture addition compared to treatments lacking moisture addition (Figure 4.16). NAGase activity showed a significant interaction between moisture addition treatment and month, and NAGase activity was generally greater in moisture addition treatments versus treatments without moisture addition (Figure 4.17). The largest difference in NAGase activity between moisture addition treatments occurred in September, where moisture addition treatments had 30\% greater activity than treatments lacking moisture addition. Phenol oxidase and peroxidase activity had a significant block by month interaction (Figures 4.18 and 4.19). The activity of all enzymes assayed at $20^{\circ} \mathrm{C}$ varied significantly by month (Table 4.3). NAGase activity was lowest in August and October and greatest in September (Figure 4.17). Cellobiosidase activity was greatest in July and lowest in August, decreasing by over $50 \%$ (Figure 4.20 ). $\beta$-glucosidase activity was higher in June and lower from August and October in comparison to other months, varying by nearly $50 \%$ (Figure 4.21 ). Acid phosphatase activity decreased by $50 \%$ from July to August and then increased by 50\% from August to September (Figure 4.22). Phenol oxidase activity was approximately $50 \%$ higher in October versus other months (Figure 4.18). Peroxidase activity decreased by $40 \%$ from April to June (Figure 4.19). No peroxidase activity was measured in July or August.

The $\mathrm{Q}_{10}$ of enzyme activity did not differ by heat or moisture treatment, although $\beta$-glucosidase $\mathrm{Q}_{10}$ showed a significant heat by moisture treatment interaction (Table 4.4, Figure 4.26). $\mathrm{Q}_{10}$ differed significantly by month for acid phosphatase (Figure 4.23) and NAGase (Figure 4.24), cellobiosidase (Figure 4.25) 
and $\beta$-glucosidase (Figure 4.26). Block also had a significant impact on $\beta$ glucosidase $\mathrm{Q}_{10}$. The majority of $\mathrm{Q}_{10}$ values were around 2, as anticipated. Acid phosphatase $\mathrm{Q}_{10}$ was approximately $50 \%$ higher in June and August versus other months, rising to around 4.5 or 5. NAGase $\mathrm{Q}_{10}$ was elevated to 6 in September, versus other months, which had a NAGase $\mathrm{Q}_{10}$ around 2 to 3. Cellobiosidase $\mathrm{Q}_{10}$ was approximately $66 \%$ greater in June and August when it rose to around 6. $\beta$ glucosidase $\mathrm{Q}_{10}$ was about $50 \%$ lower in May with a $\mathrm{Q}_{10}$ of 1 versus other months.

\subsection{Discussion}

The results generally support our prediction that enzyme activity would be higher at higher versus lower temperatures, when enzyme activities were measured at relevant field temperatures $\left(15^{\circ} \mathrm{C}\right.$ for unheated plots and $20^{\circ} \mathrm{C}$ for heated plots). The potential enzyme activities in heated treatments were typically higher than those in unheated treatments, and there was significantly higher potential activity in heated versus unheated plots for four of the six enzymes assayed. Few other published studies have conducted enzyme assays at two different incubation temperatures. Fenner et al. (2005) compared enzyme activity along a range of temperatures and found that the optimum temperature for enzyme activity was often correlated to the maximum field temperature when peat samples were taken throughout the year. This suggests that the activity of enzymes in the field changes in response to temperature. It is important to conduct enzyme assays close to field temperatures in order to determine the ecological significance of potential enzyme rates. Although this study did not perfectly match the soil field temperatures in all months, our incubation temperatures were similar to field temperatures from May to September.

The interaction between enzyme activity and soil moisture is less clear. When soil moisture treatment had a significant impact on potential enzyme activity it tended to have a positive impact on hydrolytic enzyme activity and a negative impact on oxidative enzyme activity. This is contrary to our hypothesis that increased soil moisture would lead to higher enzyme activity due to increased diffusion of nutrients and substrates (Allison 2005). When measured at the $20{ }^{\circ} \mathrm{C}$ incubation temperature, some hydrolytic enzyme activities responded positively to moisture addition, 
including NAGase and acid phosphatase, although this pattern was not consistent in all months. Because substrate is not limited in potential enzyme activity assays, we can assume that increased activity is a result of increased efficiency or quantity of enzymes present in the soil. Therefore, our results indicate that moisture may be limiting hydrolytic enzyme production or activity in plots lacking moisture addition. Sardans and Peñuelas (2004) also found that a lack of moisture decreased hydrolytic enzyme activity in a drought manipulation study from a Mediterranean oak forest.

Phenol oxidase activity tended to be lower in soils with a history of moisture addition. This may be due to the fact that phenol oxidase requires oxygen as a terminal electron acceptor, and water displaces oxygen in soil pores, however soil moisture measurements indicate that the soil was well aerated throughout most of the year. Increased soil moisture may have increased the diffusion of more labile $\mathrm{C}$ substrates, decreasing the need to decompose larger macromolecules, such as lignin in the soil (Allison 2005). This may have led to a decrease in phenol oxidase production and a concurrent decrease in potential activity at the $20{ }^{\circ} \mathrm{C}$ incubation temperature. Moisture sensitivity of enzyme activity has been monitored more directly by altering moisture content of soil slurries (Steinweg et al. 2012). Future investigations should attempt to match the moisture conditions of field soils to make more direct comparisons between soil moisture content and potential enzyme activity. This will allow soil $\mathrm{C}$ models to incorporate information on soil microbial processes at various soil moisture contents.

The most striking result is the seasonal pattern present in the enzyme activity data for all enzymes. A clear decline in all enzyme activity levels occurred by August. This is likely due to a drought in the region during the later portion of the growing season of 2011. The soil was driest in August, just before September samples were taken. Enzyme activities increased again in September, after more rain had fallen, although soil temperatures were lower. It is possible that increased input of $\mathrm{C}$ and nutrient resources from leaf and root litter in September caused increased enzyme activity (Weintraub et al. 2007). Additionally, freeze-thaw cycles in the fall may have aided the decomposition of this fresh litter (Yania et al. 2004), leading to 
the production of more hydrolytic enzymes as the autumn season progressed. Hydrolytic enzyme activity may also be linked to the growth of plants. Although we anticipated that enzyme activity would be greater during the growing season, when root exudation is greatest (Brooks et al. 2004), some studies have found that enzyme activity is lower during the active growing season compared to the remainder of the year (Bell et al. 2010, Weintraub et al. 2007). The $\mathrm{Q}_{10}$ of all hydrolytic enzyme activities also varied seasonally, lending more evidence that the thermal optimum of enzyme activity is temperature dependent (Fenner et al. 2005). Current soil carbon and nutrient cycling models should take the seasonality of microbial processes into account to increase the accuracy of climate predictions.

A more detailed examination of how different metabolic pathways respond to climate change can be performed by quantifying the amount of substrate present and the activity of different functional types of enzymes in field soils. Although our results at common incubation temperatures are indicative of the quantity of enzymes present, they do not directly measure the amount of enzymes (German et al. 2011). Using quantitative PCR of RNA transcripts in combination with proteomics is one method that could be used to overcome this hurdle (Kellner et al. 2010). The amount of substrate present in field soils also needs to be considered. Potential enzyme activity assays are conducted with a saturating level of substrate by design (SaiyaCork et al. 2002, Sinsabaugh et al. 2005). In order to understand the limitations of enzyme activity under field conditions it is imperative to know the concentration of the substrates that these enzymes act upon. In addition to methods such as electrospray ionization mass spectrometry, recent advances in NMR technology have made it possible to determine the chemical composition of organic matter in the soil (Clemente et al. 2012). Future studies should apply these methods to soils from experimental climate change manipulations in order to gain a broader understanding of how climate change will impact carbon and nutrient dynamics in soils.

\subsection{Conclusion}

In conclusion we found that elevated temperature led to higher enzyme activity rates for four out of six enzymes assayed. Moisture addition may have 
increased the abundance of two hydrolytic enzymes and decreased the abundance of one oxidative enzyme. These findings give partial support our hypothesis that soil warming and moisture addition would increase enzyme activity and the abundance of enzymes present in the soil. These treatments generally did not alter the $\mathrm{Q}_{10}$ of enzyme activity, suggesting that the temperature sensitivity of enzyme activity did not differ with experimental treatment. Future studies should attempt to control the temperature and moisture of enzyme assays in the laboratory in a way that mimics soil temperature and moisture conditions in the field. Conducting enzyme assays at a broader range of temperatures would allow temperature sensitivity of enzyme activity to be calculated with a greater degree of precision. Combining a potential enzyme activity approach with a measurement of microbial biomass will help to improve soil carbon cycling models, particularly when microbial growth efficiency is considered (Frey et al. 2013). More information about the quality of organic substrates present in these soils will help us to elucidate the mechanisms that may feedback into climate change. 
Table 4.1 Results of repeated measures ANOVA for enzyme activity at relevant treatment temperature. Alpha was set at 0.05 and p-values are shown. Significant pvalues are bolded.

\begin{tabular}{llllllllll} 
& Block & Heat & Water & $\begin{array}{l}\text { Heat } \mathbf{x} \\
\text { Water }\end{array}$ & Month & $\begin{array}{l}\text { Month } \\
\mathbf{x} \\
\text { Block }\end{array}$ & $\begin{array}{l}\text { Month } \\
\mathbf{x} \text { Heat }\end{array}$ & $\begin{array}{l}\text { Month } \\
\mathbf{x} \\
\text { Water }\end{array}$ & $\begin{array}{l}\text { Month } \\
\mathbf{x} \text { Heat } \\
\mathbf{x} \\
\text { Water }\end{array}$ \\
\hline Cellobiosidase & 0.200 & $\mathbf{0 . 0 3 9}$ & 0.392 & 0.871 & $<\mathbf{0 . 0 0 1}$ & 0.781 & 0.206 & 0.892 & 0.337 \\
\hline $\boldsymbol{\beta}$-glucosidase & 0.202 & $\mathbf{0 . 0 1 1}$ & 0.164 & 0.711 & $<\mathbf{0 . 0 0 1}$ & 0.246 & $\mathbf{0 . 0 3 0}$ & 0.105 & 0.103 \\
\hline $\begin{array}{l}\text { Acid } \\
\text { Phosphatase }\end{array}$ & 0.571 & 0.232 & 0.154 & 0.779 & $<\mathbf{0 . 0 0 1}$ & 0.540 & 0.715 & 0.825 & 0.825 \\
\hline NAGase & 0.126 & $\mathbf{0 . 0 3 9}$ & 0.390 & 0.253 & $<\mathbf{0 . 0 0 1}$ & 0.178 & 0.415 & 0.734 & 0.380 \\
\hline Phenol oxidase & 0.463 & $\mathbf{0 . 0 4 7}$ & 0.883 & 0.959 & $<\mathbf{0 . 0 0 1}$ & 0.223 & 0.537 & 0.723 & 0.551 \\
\hline Peroxidase & 0.561 & 0.974 & 0.781 & 0.718 & $<\mathbf{0 . 0 0 1}$ & 0.113 & 0.971 & 0.916 & 0.851
\end{tabular}

Table 4.2 Results of repeated measures ANOVA for enzyme activity at $15^{\circ} \mathrm{C}$.

Alpha was set at 0.05 and p-values are shown. Significant p-values are bolded.

\begin{tabular}{|c|c|c|c|c|c|c|c|c|c|}
\hline & Block & Heat & Water & $\begin{array}{l}\text { Heat x } \\
\text { Water }\end{array}$ & Month & $\begin{array}{l}\text { Month } \\
\text { x } \\
\text { Block }\end{array}$ & $\begin{array}{l}\text { Month } \\
\text { x Heat }\end{array}$ & $\begin{array}{l}\text { Month } \\
\text { x } \\
\text { Water }\end{array}$ & $\begin{array}{l}\text { Month } \\
\text { x Heat } \\
\text { x } \\
\text { Water }\end{array}$ \\
\hline Cellobiosidase & 0.254 & 0.896 & 0.220 & 0.678 & $<0.001$ & 0.996 & 0.851 & 0.915 & 0.502 \\
\hline$\beta$-glucosidase & 0.068 & 0.498 & 0.130 & 0.237 & $<0.001$ & 0.208 & 0.995 & 0.414 & 0.087 \\
\hline $\begin{array}{l}\text { Acid } \\
\text { Phosphatase }\end{array}$ & 0.084 & 0.976 & 0.092 & 0.407 & $<0.001$ & 0.779 & 0.803 & 0.965 & 0.983 \\
\hline NAGase & 0.169 & 0.268 & 0.188 & 0.140 & 0.043 & 0.207 & 0.398 & 0.359 & 0.258 \\
\hline Phenol oxidase & 0.023 & 0.989 & 0.557 & 0.455 & $<0.001$ & 0.013 & 0.991 & 0.968 & 0.577 \\
\hline Peroxidase & 0.257 & 0.345 & 0.734 & 0.816 & $<0.001$ & 0.045 & 0.565 & 0.891 & 0.369 \\
\hline
\end{tabular}

Table 4.3 Results of repeated measures ANOVA for enzyme activity at $20^{\circ} \mathrm{C}$.

Alpha was set at 0.05 and p-values are shown. Significant p-values are bolded.

\begin{tabular}{lllllllllll} 
& Block & Heat & Water & $\begin{array}{l}\text { Heat } \mathbf{x} \\
\text { Water }\end{array}$ & Month & $\begin{array}{l}\text { Month } \\
\mathbf{x} \\
\text { Block }\end{array}$ & $\begin{array}{l}\text { Month } \\
\mathbf{x} \text { Heat }\end{array}$ & $\begin{array}{l}\text { Month } \\
\mathbf{x} \\
\text { Water }\end{array}$ & $\begin{array}{l}\text { Month } \\
\mathbf{x} \text { Heat } \\
\mathbf{x} \\
\text { Water }\end{array}$ \\
\hline Cellobiosidase & 0.128 & 0.816 & 0.117 & 0.409 & $<\mathbf{0 . 0 0 1}$ & 0.338 & 0.996 & 0.460 & 0.961 \\
\hline B-glucosidase & 0.711 & 0.951 & 0.618 & 0.704 & $<\mathbf{0 . 0 0 1}$ & 0.109 & 0.857 & 0.051 & 0.856 \\
\hline $\begin{array}{l}\text { Acid } \\
\text { Phosphatase }\end{array}$ & 0.475 & 0.765 & $\mathbf{0 . 0 4 5}$ & 0.575 & $<\mathbf{0 . 0 0 1}$ & 0.062 & 0.831 & 0.923 & 0.521 \\
\hline NAGase & 0.493 & 0.143 & 0.073 & 0.559 & $<\mathbf{0 . 0 0 1}$ & 0.052 & 0.219 & $\mathbf{0 . 0 1 0}$ & 0.551 \\
\hline Phenol oxidase & 0.374 & 0.330 & 0.332 & 0.426 & $<\mathbf{0 . 0 0 1}$ & $\mathbf{0 . 0 4 8}$ & 0.254 & 0.766 & 0.559 \\
\hline Peroxidase & 0.125 & 0.255 & 0.951 & 0.446 & $<\mathbf{0 . 0 0 1}$ & $\mathbf{0 . 0 3 8}$ & 0.455 & 0.974 & 0.810
\end{tabular}


Table 4.4 Results of repeated measures ANOVA for $\mathrm{Q}_{10}$ of enzyme activity.

Alpha was set at 0.05 and p-values are shown. Significant p-values are bolded.

\begin{tabular}{|c|c|c|c|c|c|c|c|c|c|}
\hline & Block & Heat & Water & $\begin{array}{l}\text { Heat } x \\
\text { Water }\end{array}$ & Month & $\begin{array}{l}\text { Month } \\
\text { x } \\
\text { Block }\end{array}$ & $\begin{array}{l}\text { Month } \\
\text { x Heat }\end{array}$ & $\begin{array}{l}\text { Month } \\
\text { x } \\
\text { Water }\end{array}$ & $\begin{array}{l}\text { Month } \\
\text { x Heat } \\
\text { x } \\
\text { Water }\end{array}$ \\
\hline Cellobiosidase & 0.867 & 0.878 & 0.801 & 0.106 & $<0.001$ & 0.875 & 0.981 & 0.984 & 0.706 \\
\hline$\beta$-glucosidase & 0.041 & 0.065 & 0.077 & 0.028 & 0.018 & 0.208 & 0.773 & 0.903 & 0.096 \\
\hline $\begin{array}{l}\text { Acid } \\
\text { Phosphatase }\end{array}$ & 0.826 & 0.260 & 0.562 & 0.500 & $<0.001$ & 0.693 & 0.602 & 0.815 & 0.649 \\
\hline NAGase & 0.500 & 0.187 & 0.052 & 0.140 & 0.004 & 0.782 & 0.595 & 0.063 & 0.597 \\
\hline
\end{tabular}




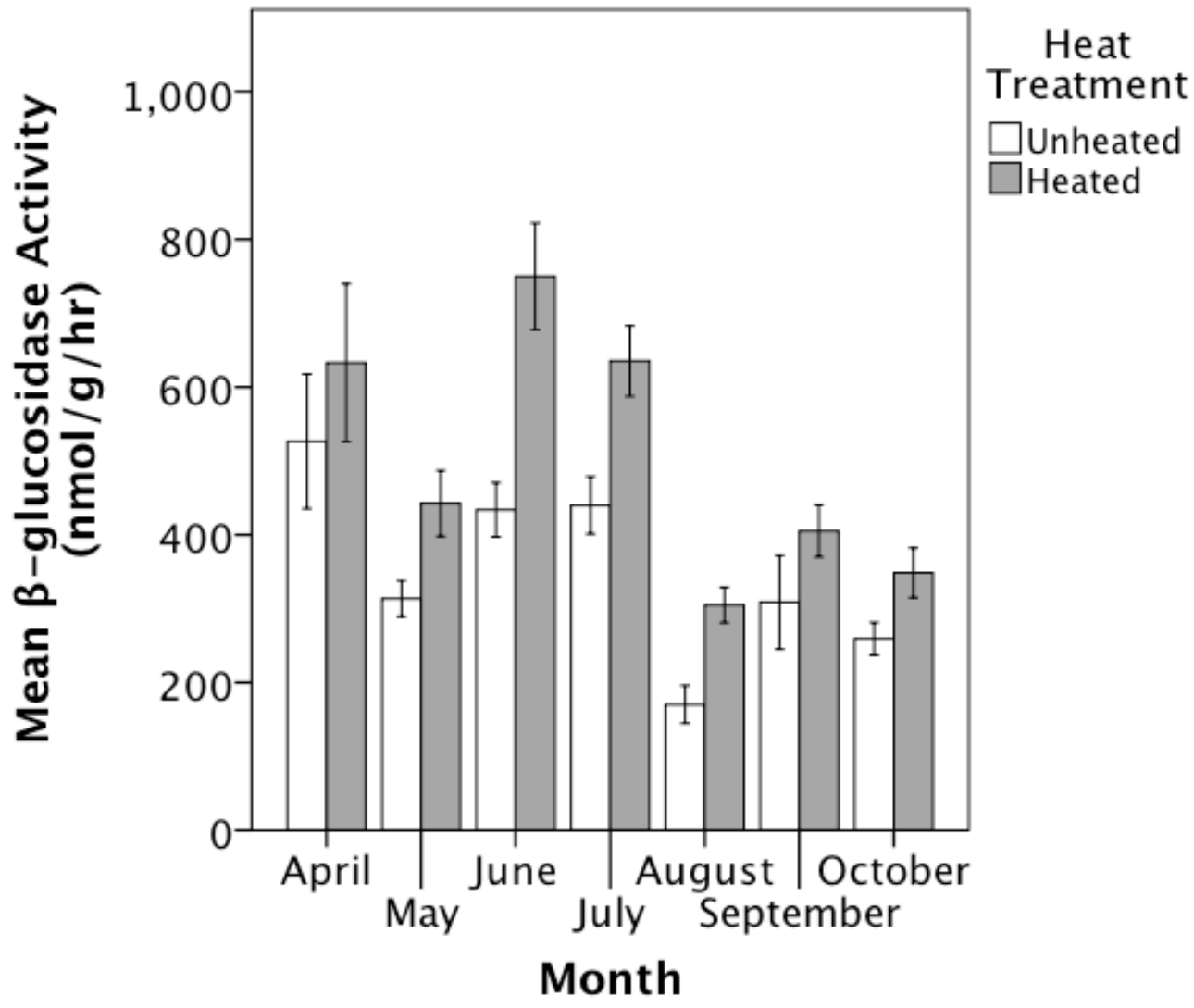

Figure 4.1 Mean $\beta$-glucosidase activity measured at relevant treatment temperature varied significantly by heat and month and showed a significant heat by month interaction. Heated treatments had greater activity than unheated treatments. Error bars represent one standard error of the mean. 


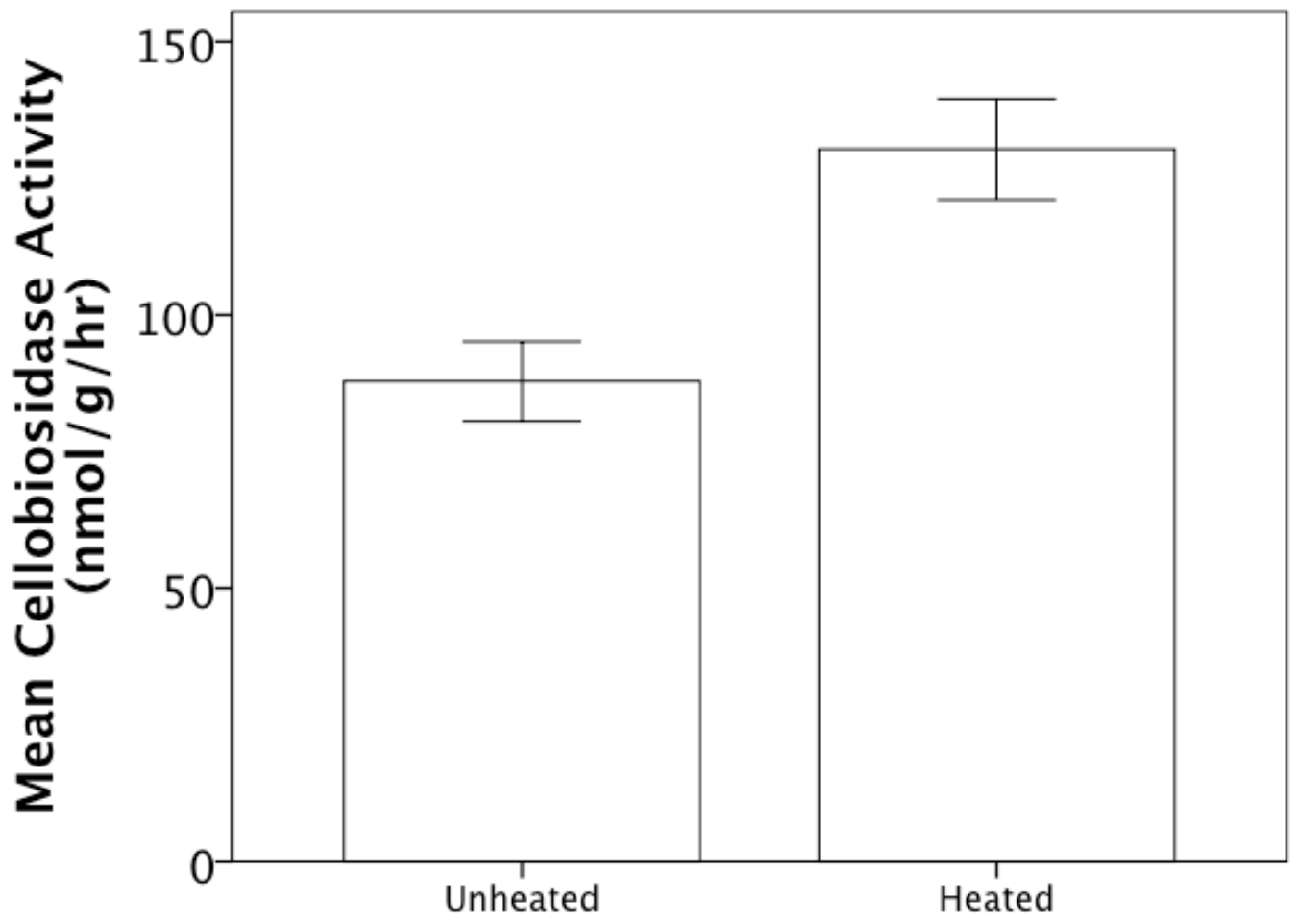

Figure 4.2 Mean cellobiosidase activity measured at relevant treatment temperature was greater in heated versus unheated treatments. Error bars are one standard error of the mean. 


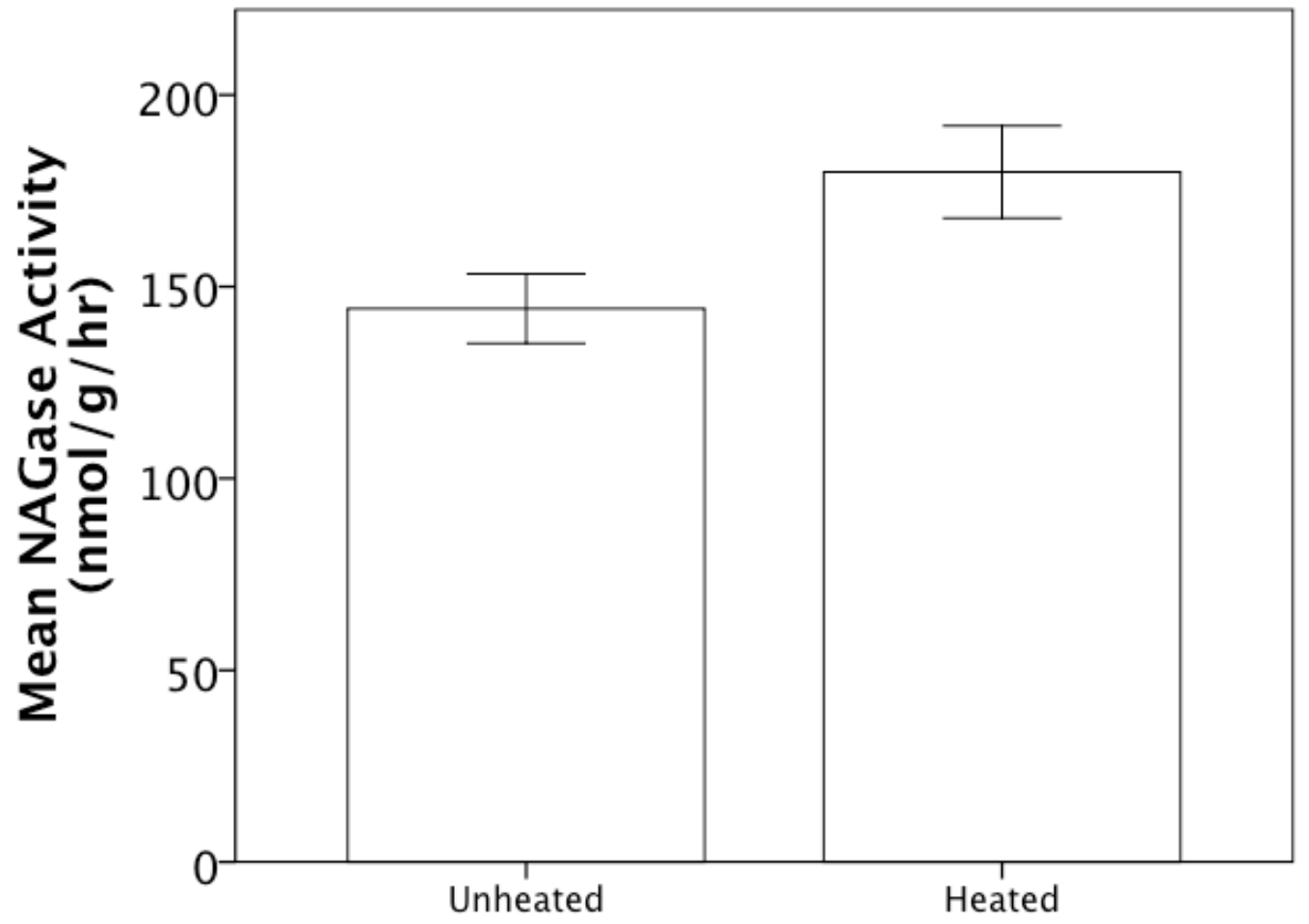

Figure 4.3 Mean NAGase activity measured at relevant treatment temperature was significantly higher in heated versus unheated treatments. Error bars represent one standard error of the mean. 


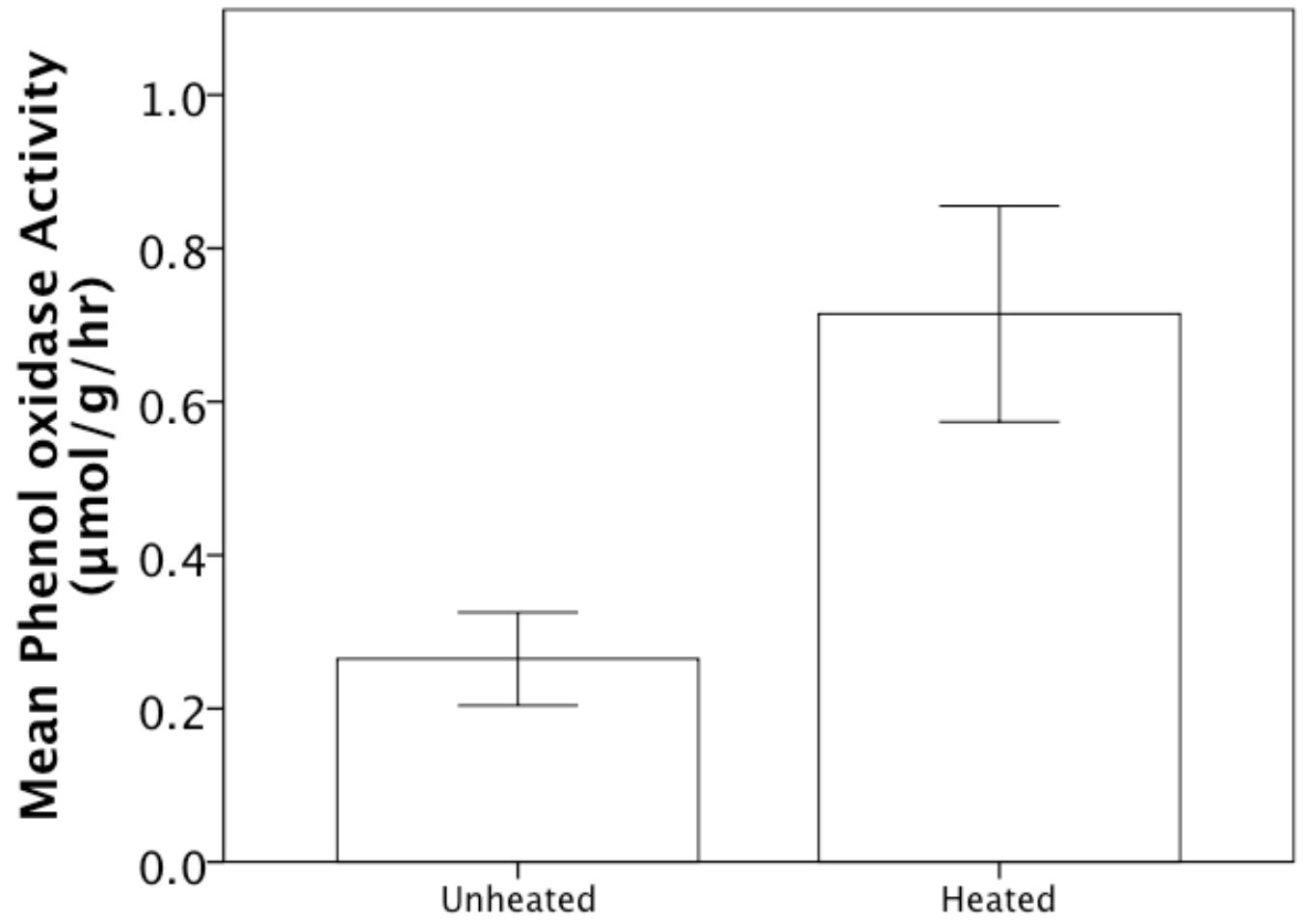

Figure 4.4 Mean phenol oxidase activity measured at the relevant treatment temperature was significantly higher in heated versus unheated treatments. Error bars represent one standard error of the mean. 


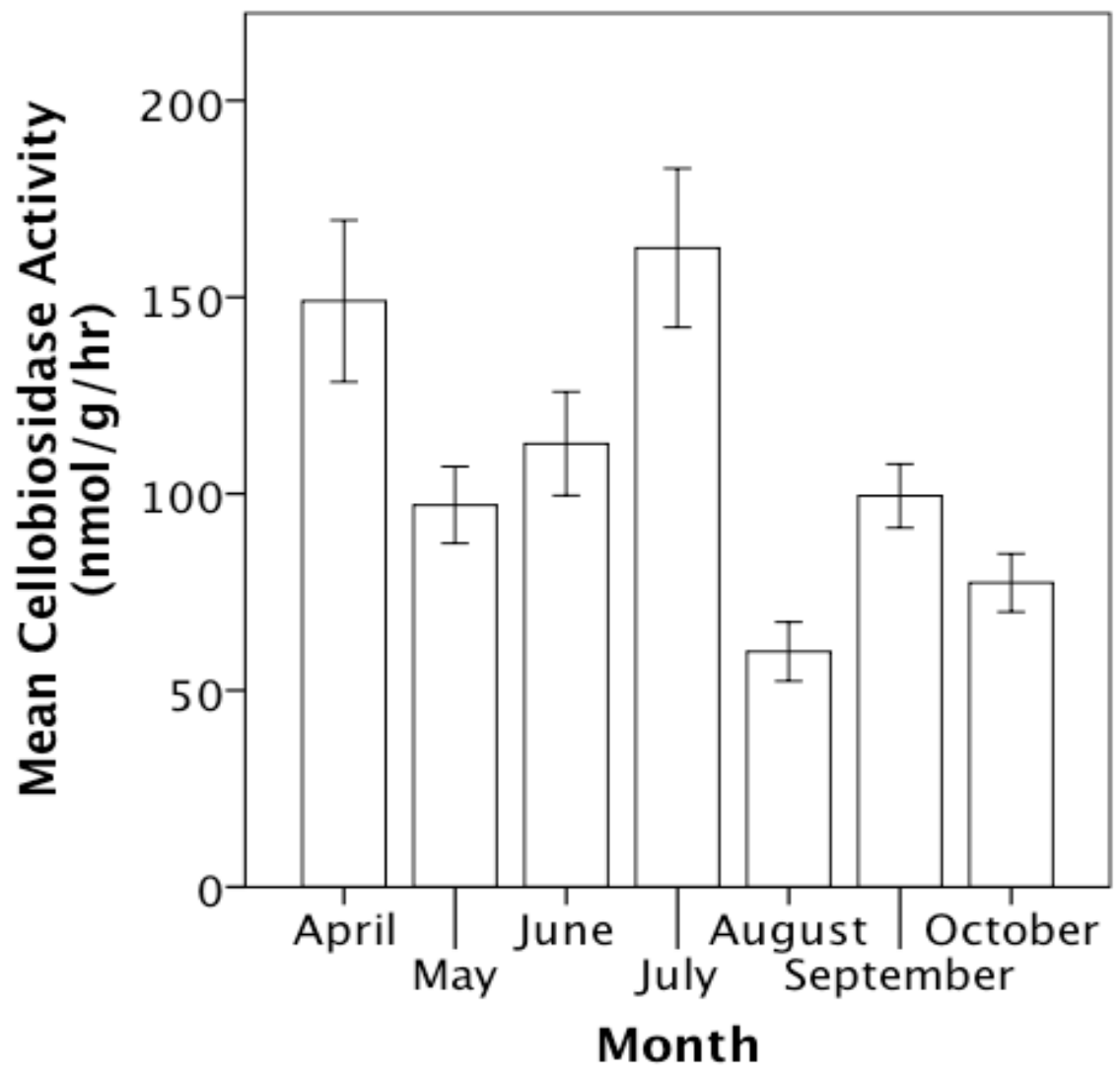

Figure 4.5 Mean cellobiosidase activity measured at relevant treatment temperature varied significantly by month. April and July had higher activity relative to other months and the cellobiosidase activity in August was relatively low. Error bars represent one standard error of the mean. 


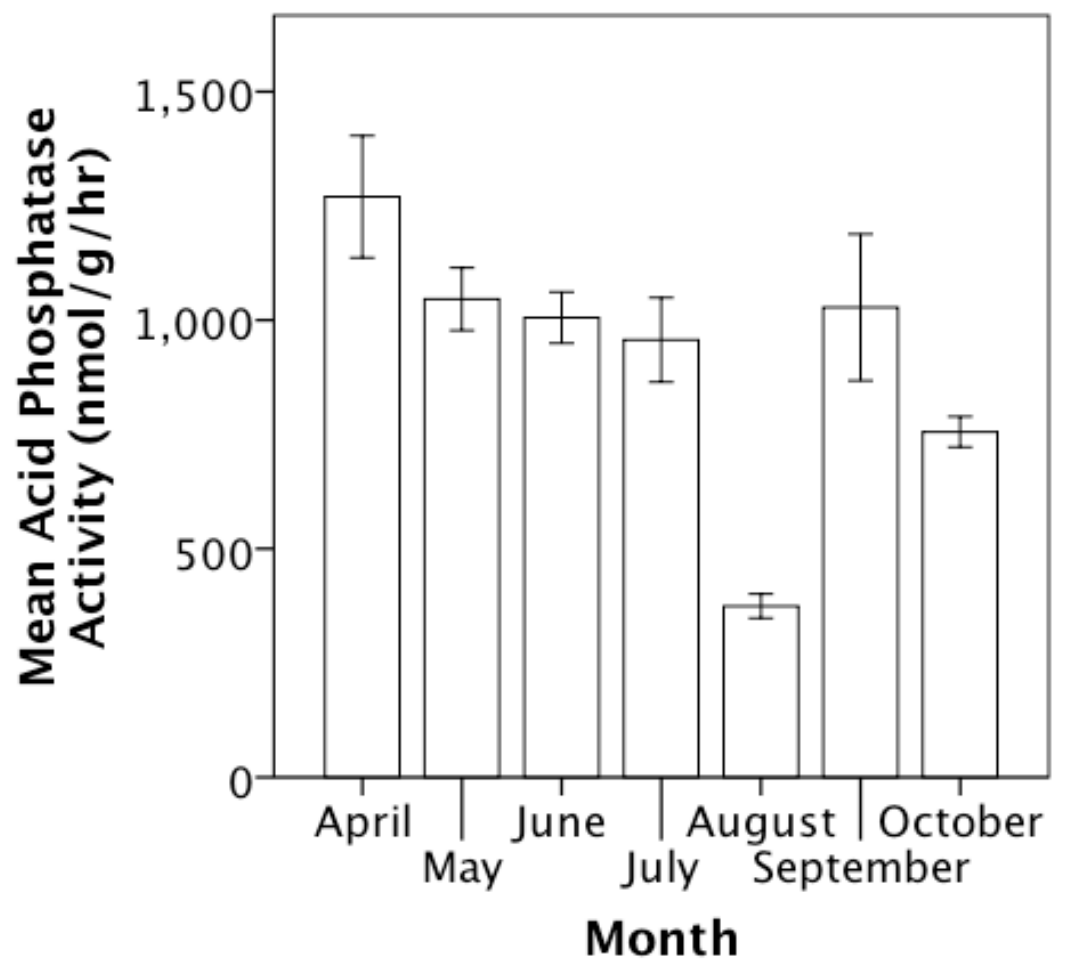

Figure 4.6 Mean acid phosphatase activity at relevant treatment temperature varied significantly by month. August showed lower activity versus other months. Error bars are one standard error of the mean. 


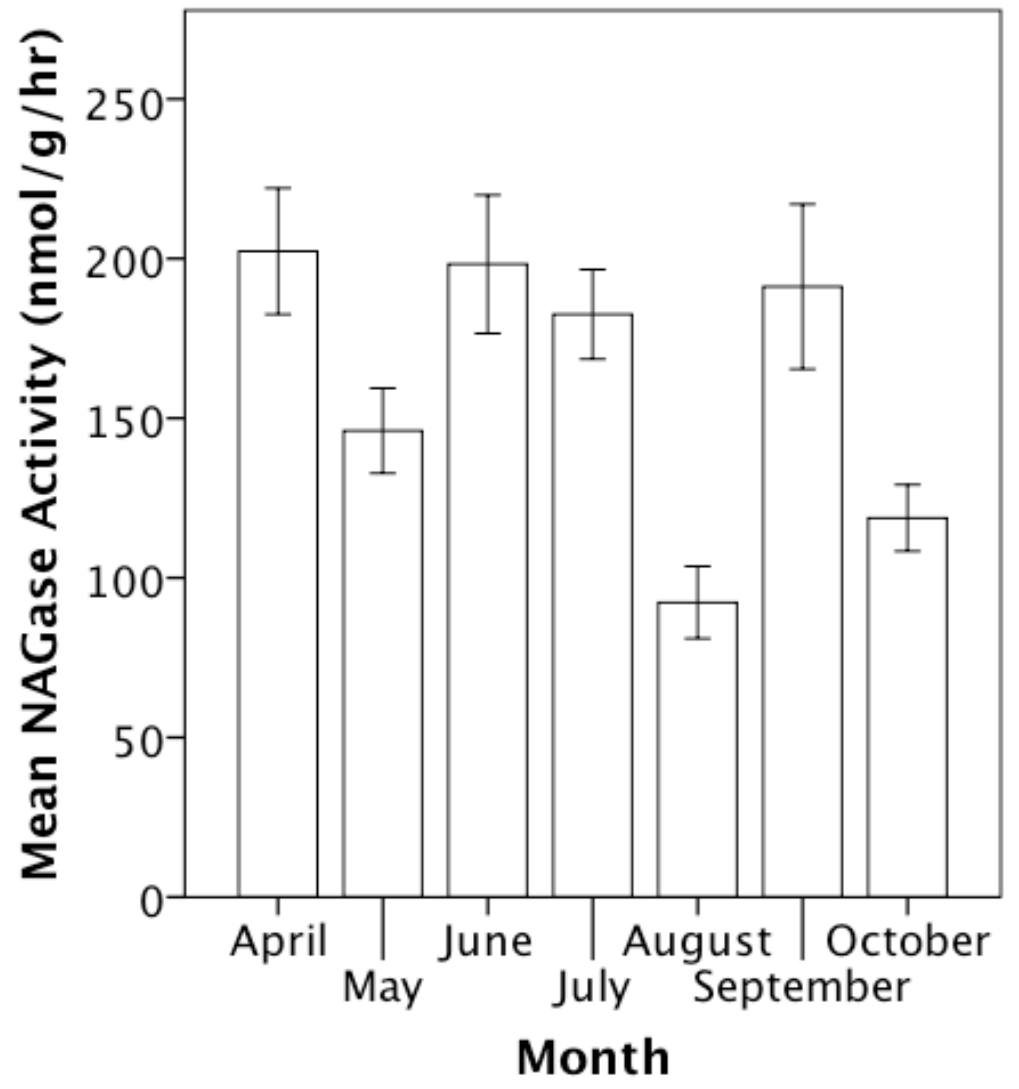

Figure 4.7 Mean NAGase activity measured at relevant treatment temperature was significantly lower in May, August and October versus other months. Error bars are one standard error of the mean. 


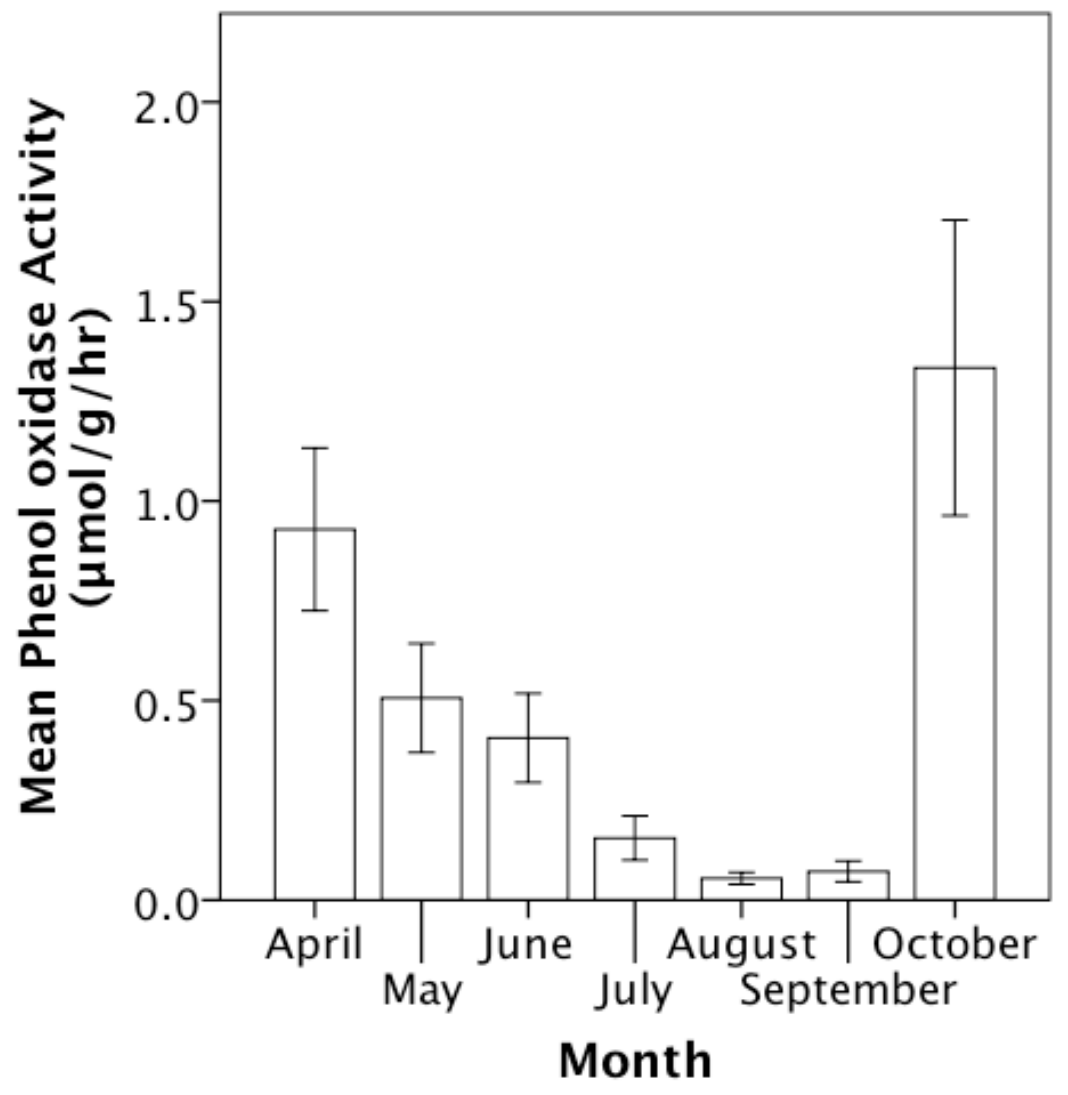

Figure 4.8 Mean phenol oxidase activity measured at relevant treatment temperature varied significantly by month. Activity decreased from April to September, then increased dramatically in October. Error bars represent one standard error of the mean. 


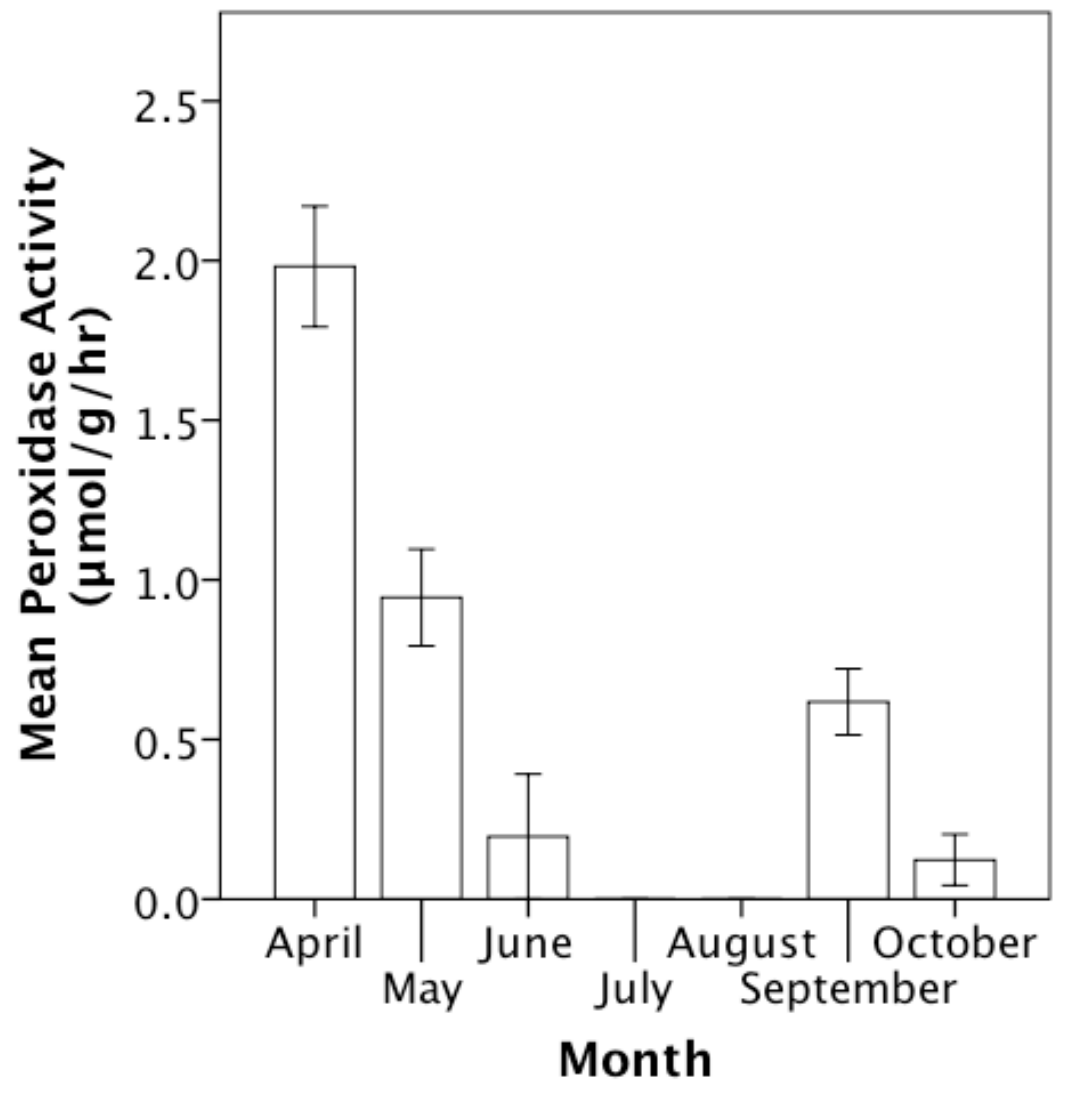

Figure 4.9 Mean peroxidase activity at relevant treatment temperature varied significantly by month. Activity decreased from April to June, and no activity was detected in July or August. Activity increased in September. Error bars are one standard error of the mean. 


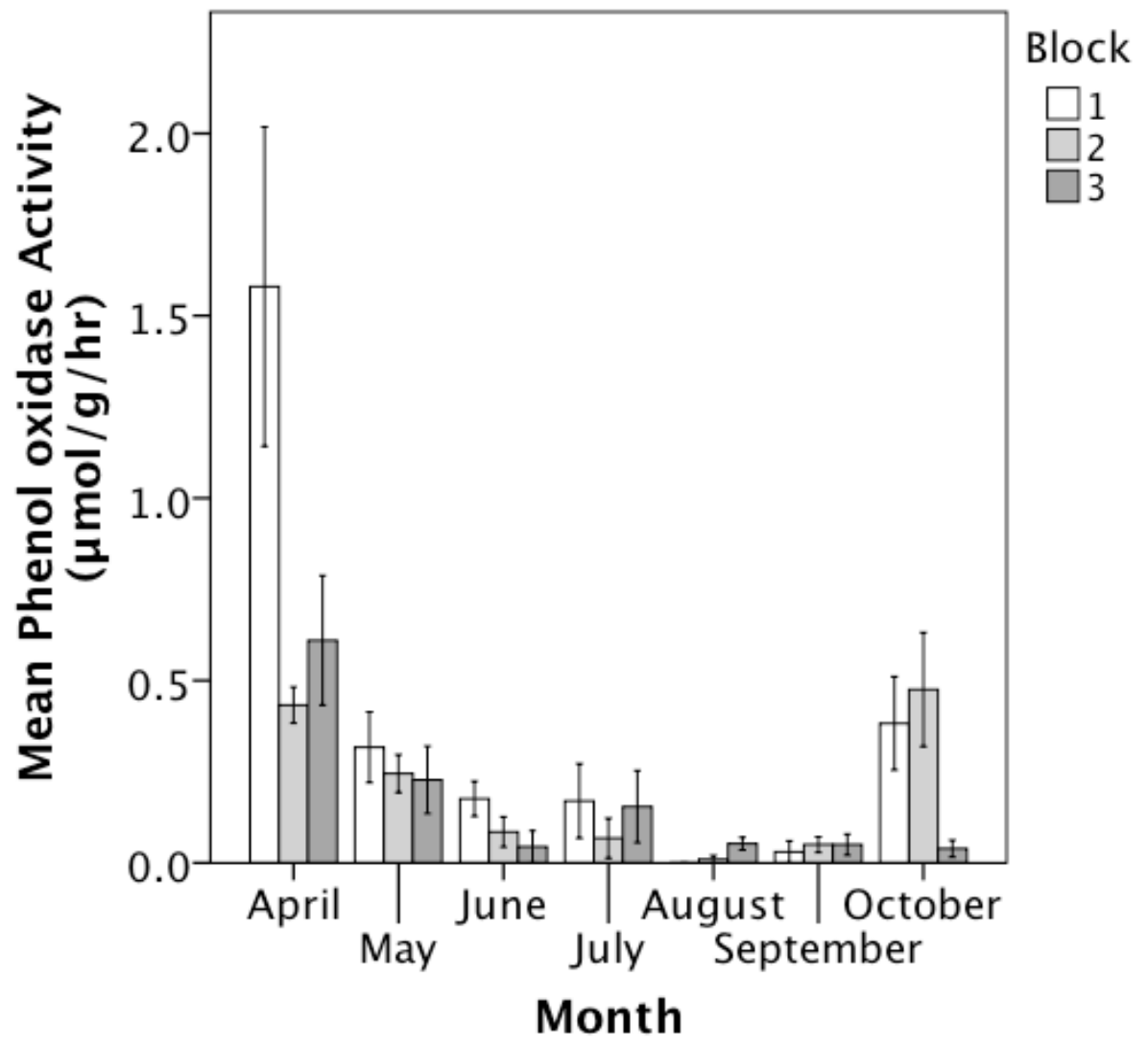

Figure 4.10 Mean phenol oxidase activity measured at $15^{\circ} \mathrm{C}$ showed a significant effect of block and month. There was also a significant block by month interaction. April had the greatest phenol oxidase activity. Error bars represent one standard error of the mean. 


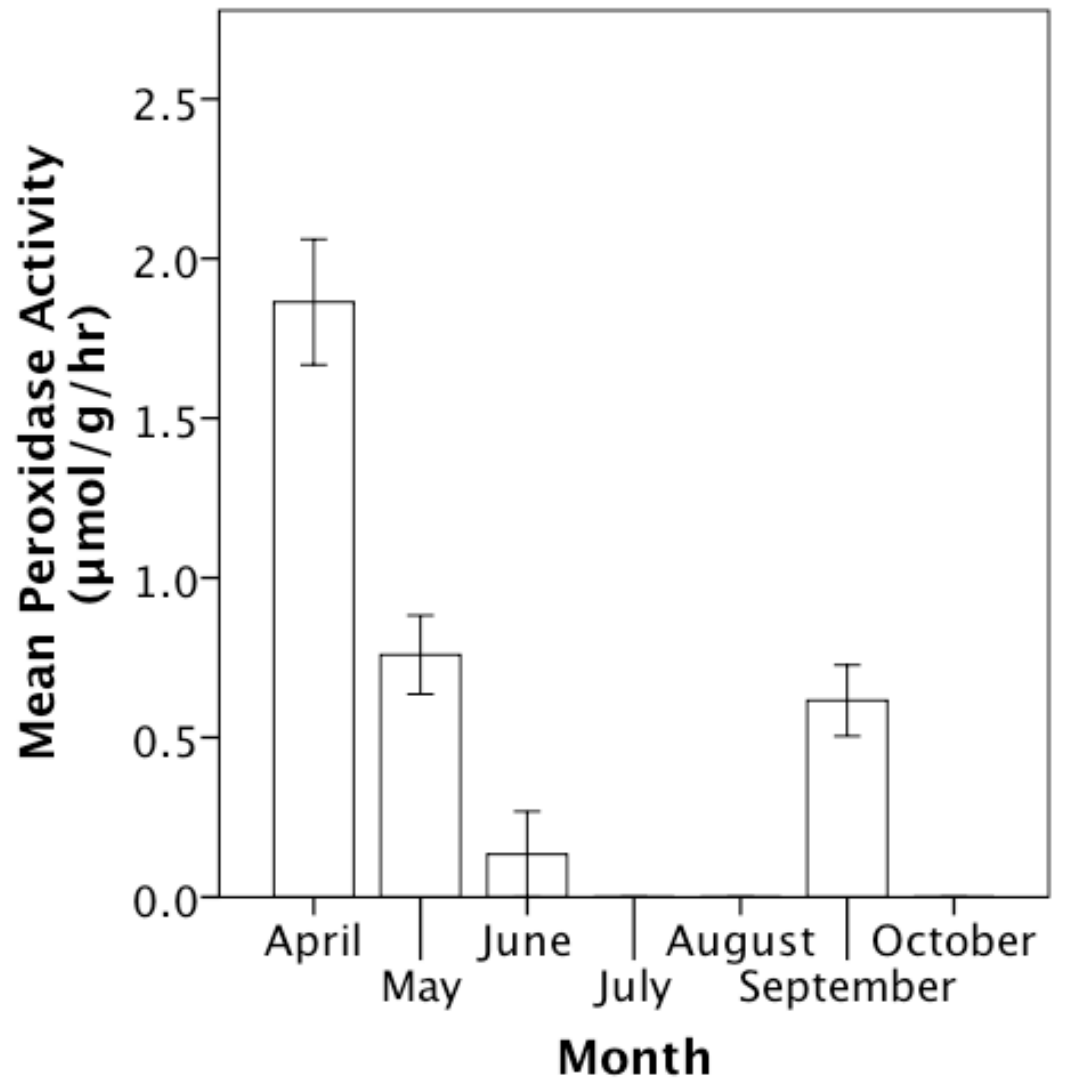

Figure 4.11 Mean peroxidase activity measured at $15^{\circ} \mathrm{C}$ varied significantly by month. Peroxidase activity decreased from April to June and activity increased again in September. There was no measureable activity in July, August or October. Error bars represent one standard error of the mean. 


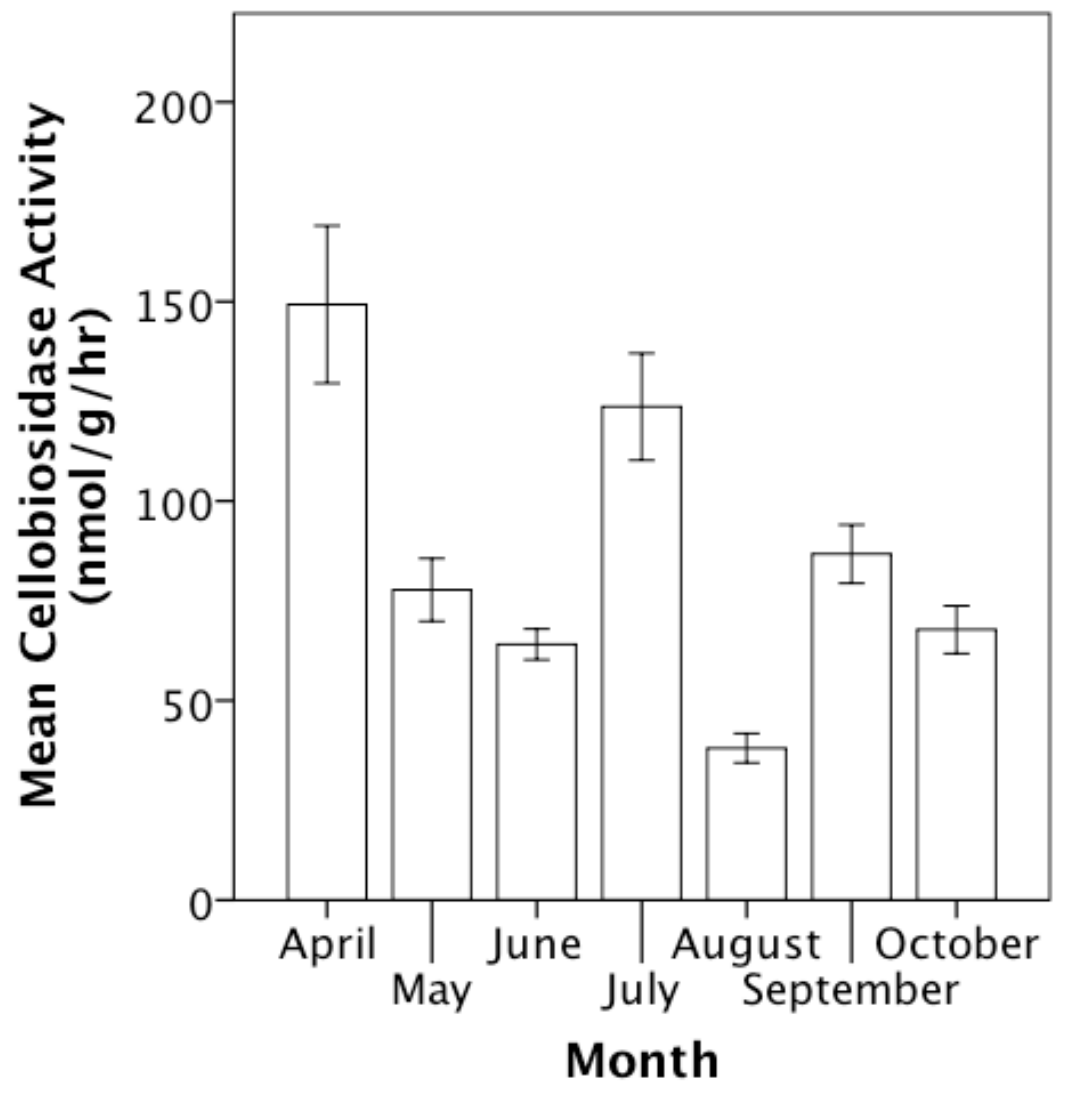

Figure 4.12 Mean cellobiosidase activity measured at $15{ }^{\circ} \mathrm{C}$ varied significantly by month. Cellobiosidase activity decreased from April to June, increased in July, and then decreased again in August. September and October showed higher activity than August. Error bars are one standard error of the mean. 


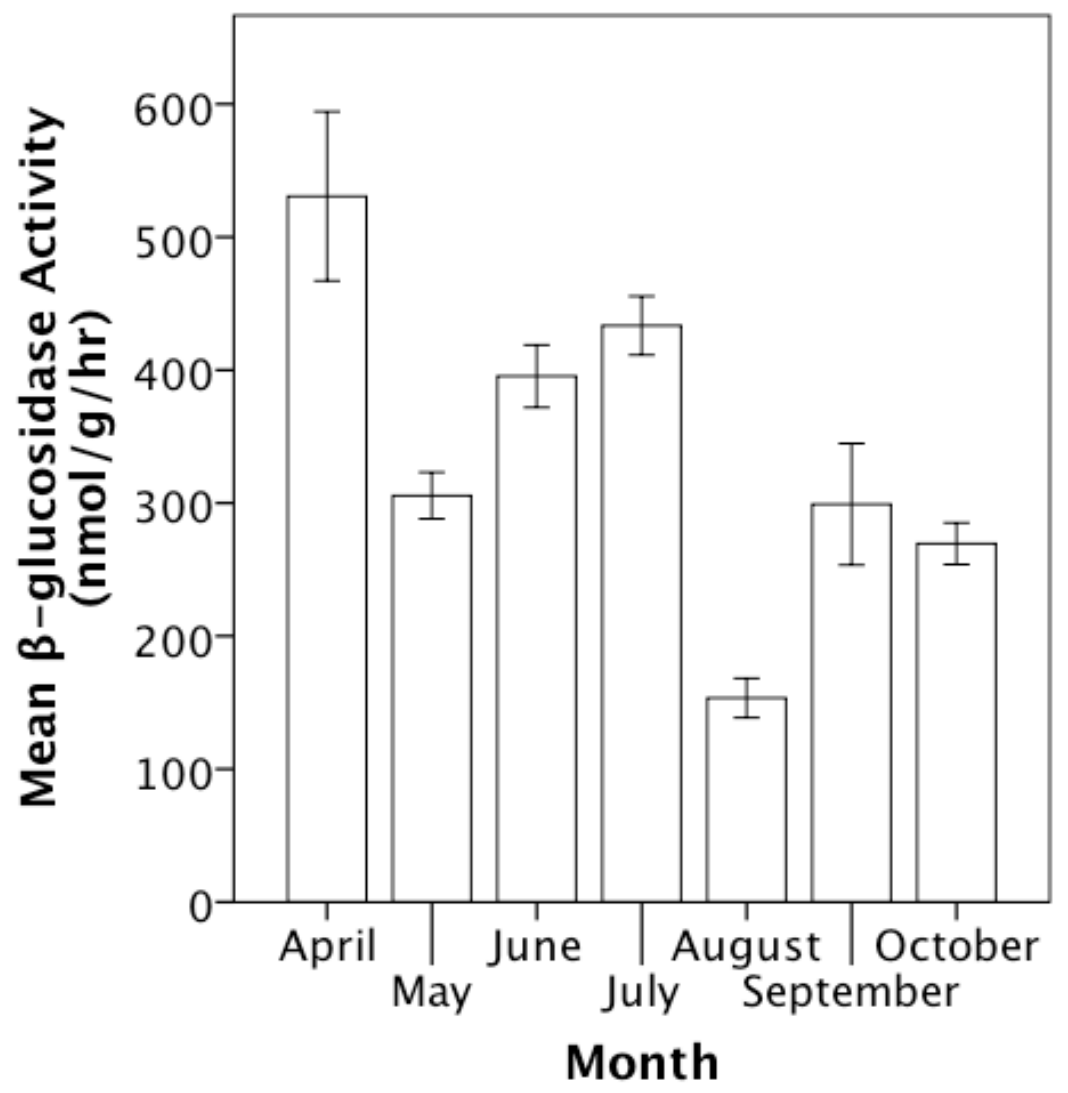

Figure 4.13 Mean $\beta$-glucosidase activity measured at $15^{\circ} \mathrm{C}$ varied significantly by month. The highest activity was measured in April. August had relatively low activity. Error bars are one standard error of the mean. 


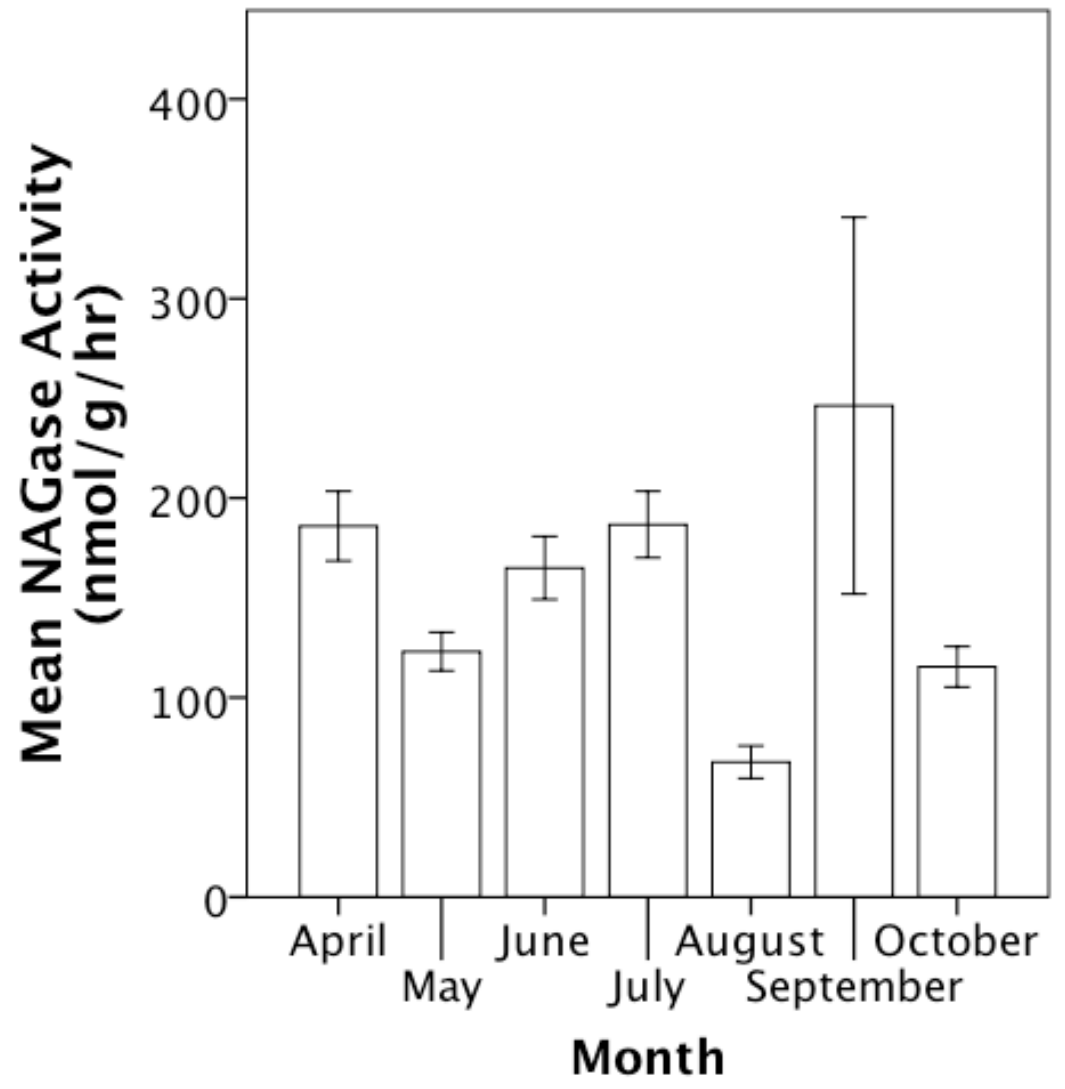

Figure 4.14 Mean NAGase activity measured at $15{ }^{\circ} \mathrm{C}$ varied significantly by month. Activity was lowest in August and highest in September. Error bars are one standard error of the mean. 


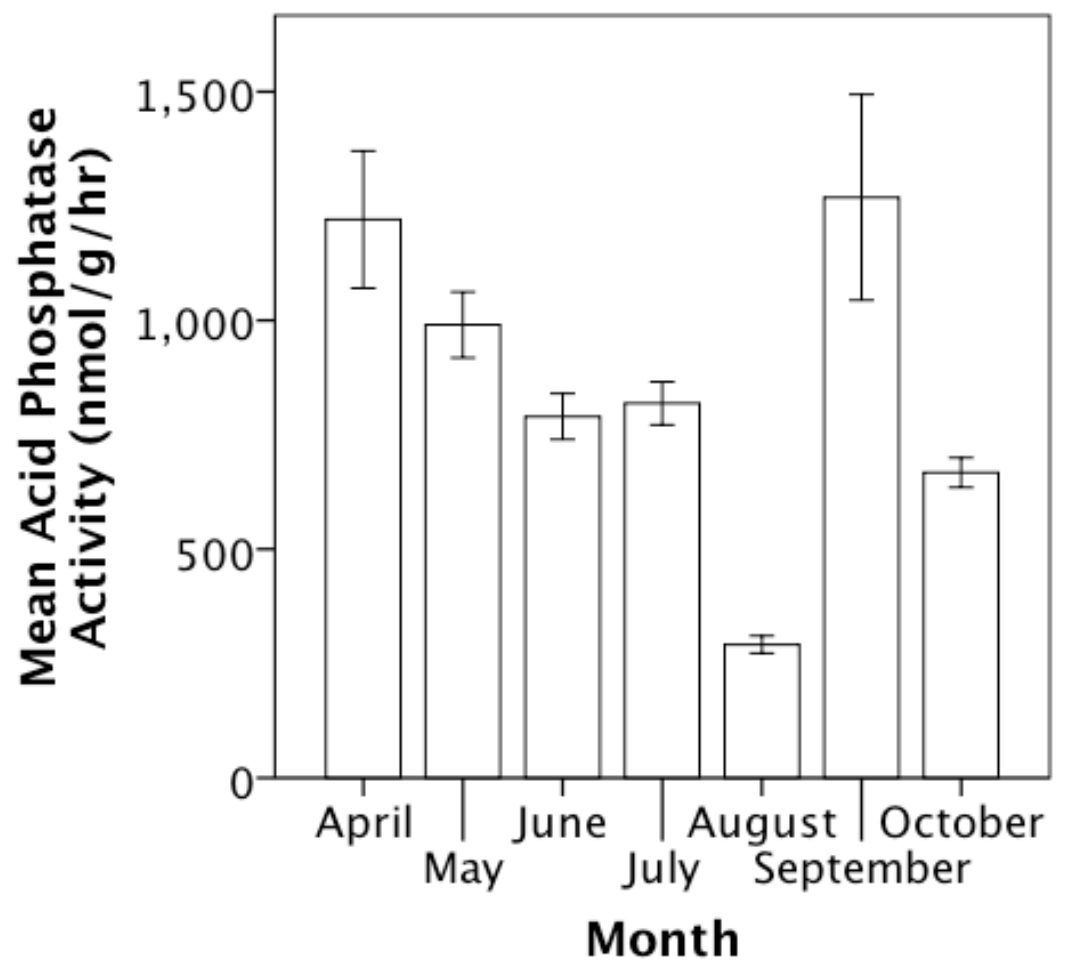

Figure 4.15 Mean acid phosphatase activity measured at $15^{\circ} \mathrm{C}$ varied significantly by month. Acid phosphatase activity declined from April to August and increased dramatically in September. Error bars are one standard error of the mean. 


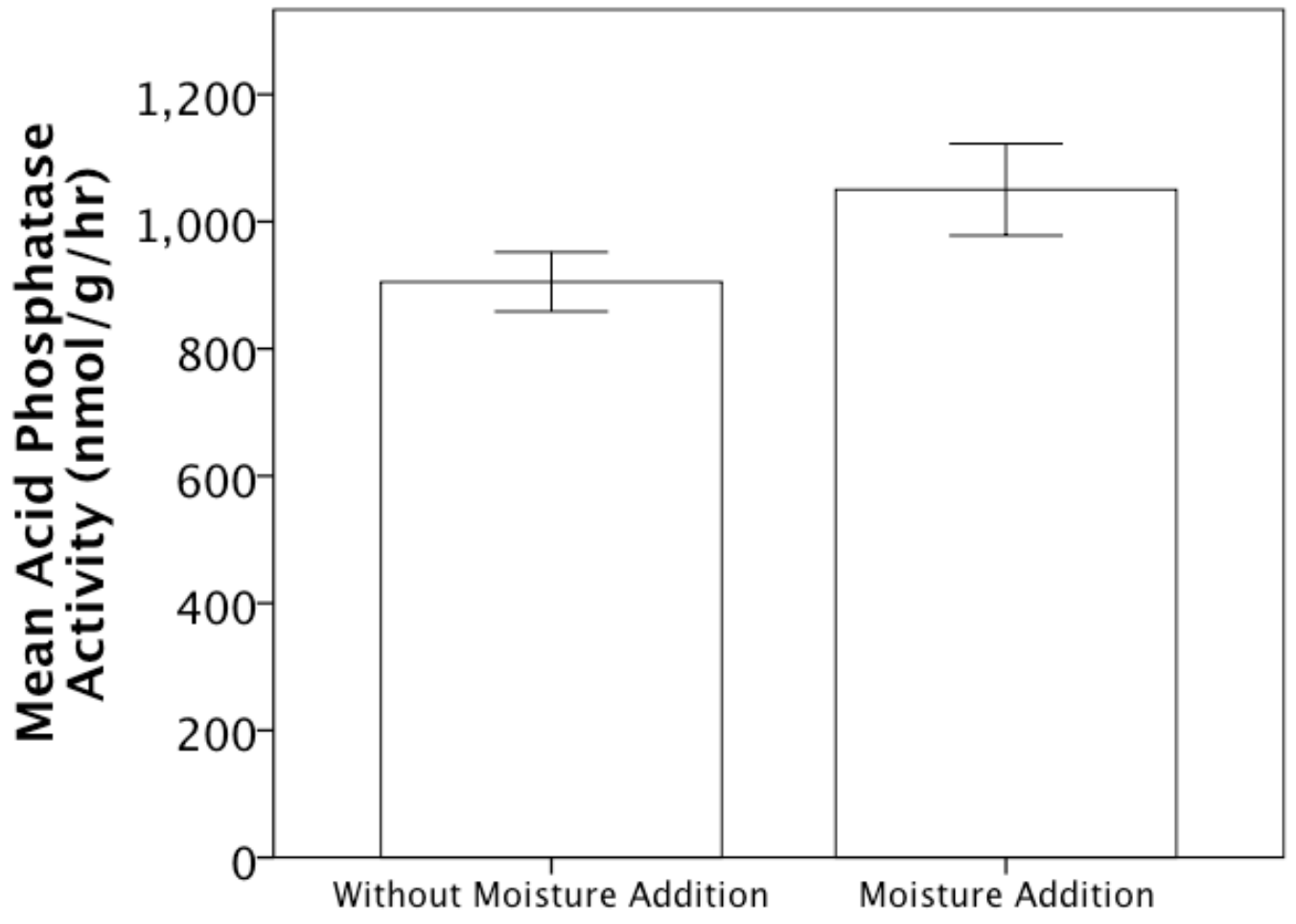

Figure 4.16 Mean acid phosphatase activity measured at $20^{\circ} \mathrm{C}$ was significantly greater in moisture addition treatments versus treatments lacking moisture addition. Error bars are one standard error of the mean. 


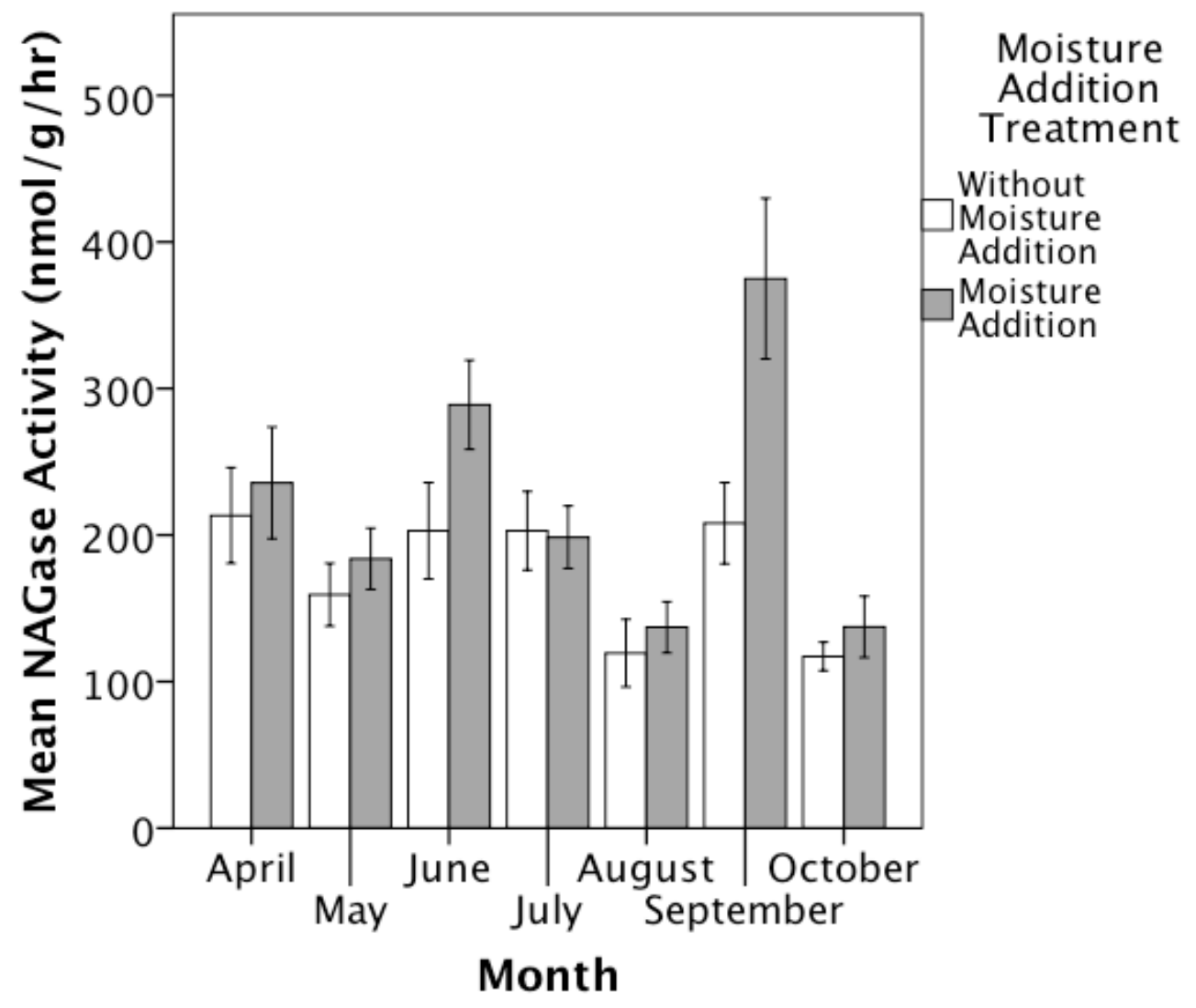

Figure 4.17 Mean NAGase activity measured at $20^{\circ} \mathrm{C}$ varied significantly by month and showed a significant interaction between month and moisture addition treatment. Moisture addition treatments generally had greater activity than treatments without moisture addition. Activity was lowest in August and highest in September. Error bars are one standard error of the mean. 


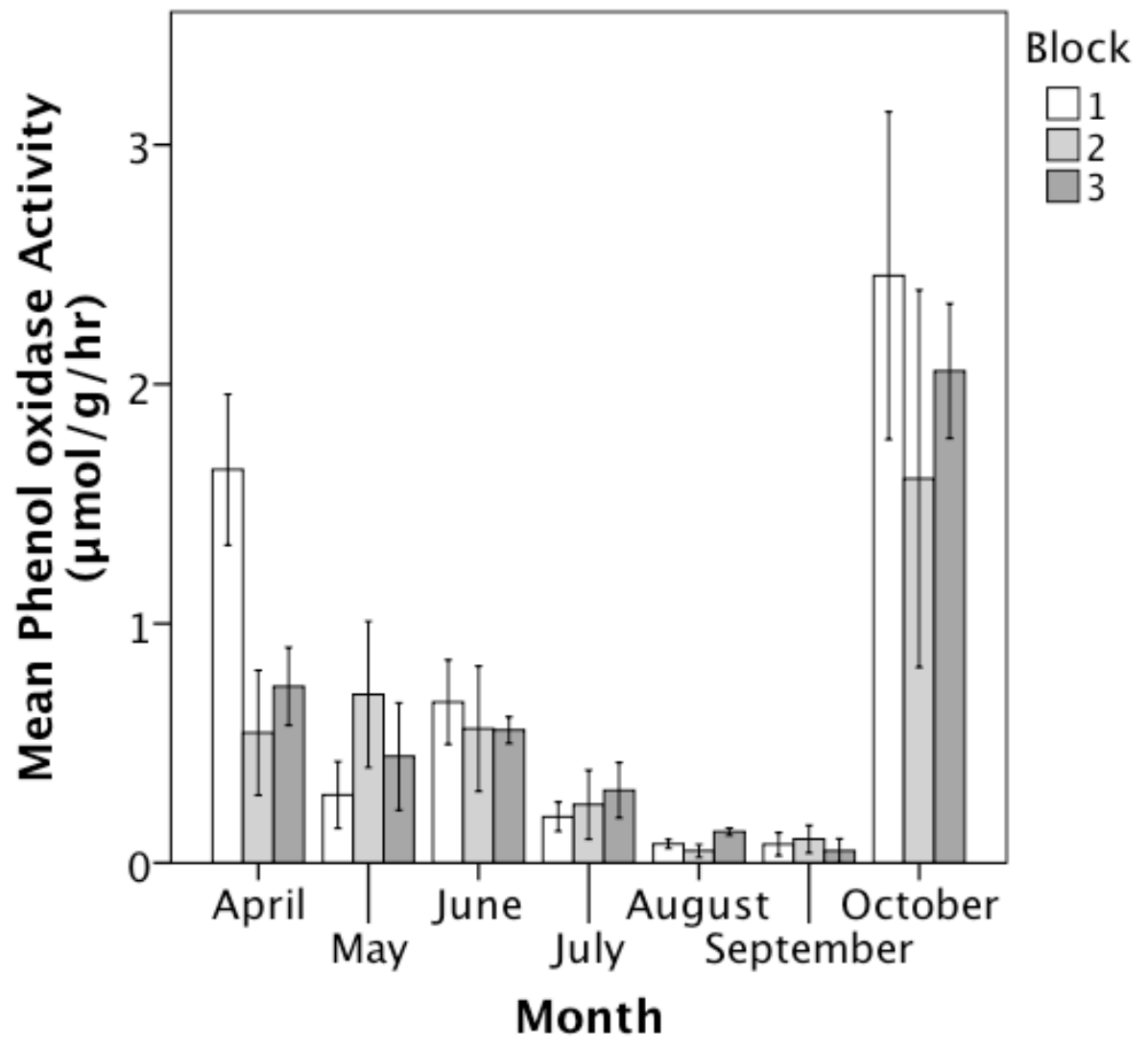

Figure 4.18 Mean phenol oxidase activity measured at $20^{\circ} \mathrm{C}$ varied significantly by month and there was a significant interaction between block and month. Phenol oxidase activity was higher in October versus other months. Error bars are one standard error of the mean. 


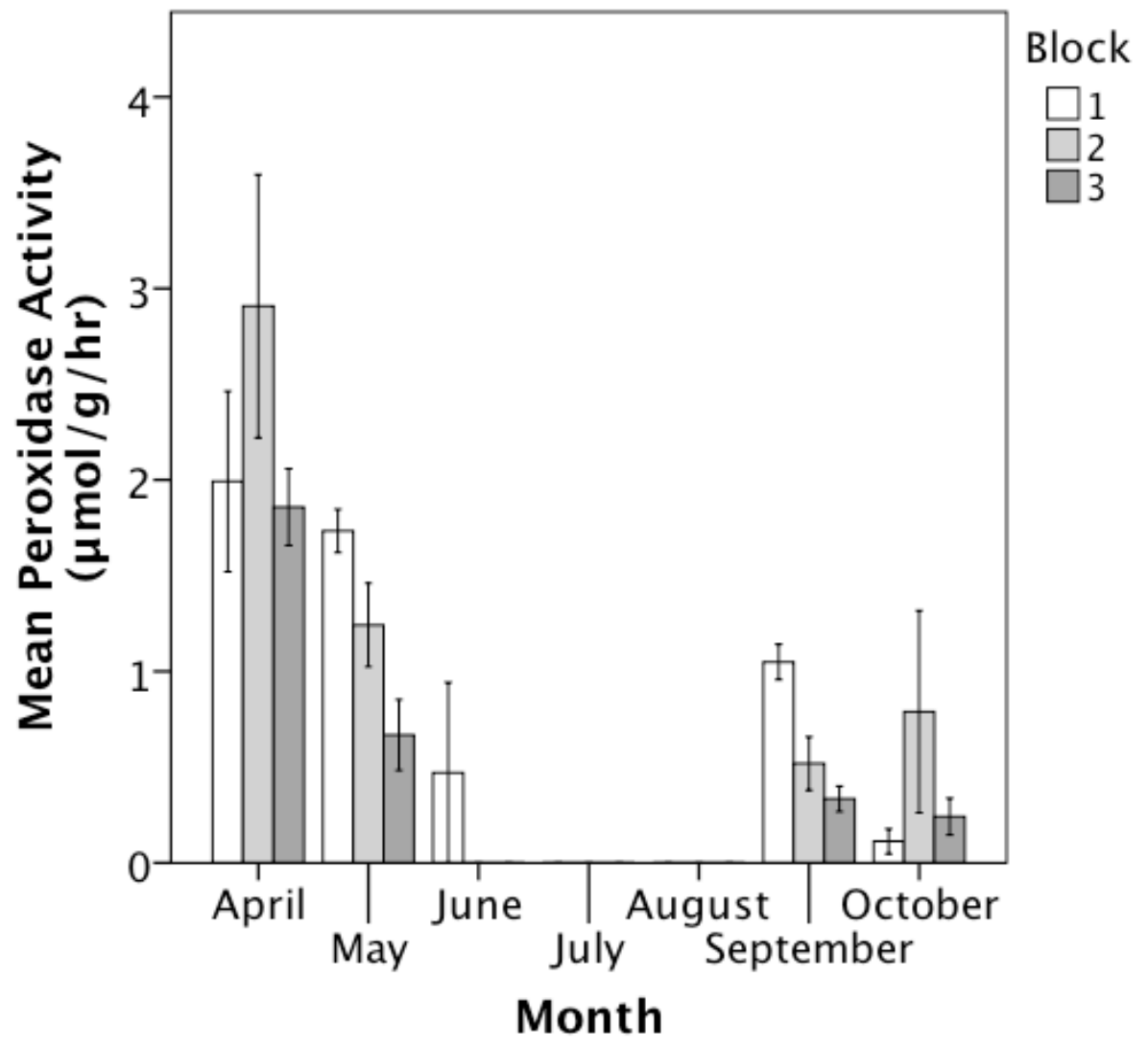

Figure 4.19 Mean peroxidase activity measured at $20^{\circ} \mathrm{C}$ varied significantly by month and there was a significant interaction between block and month. Peroxidase activity decreased from April to June. No peroxidase activity was measured in July or August. Error bars are one standard error of the mean. 


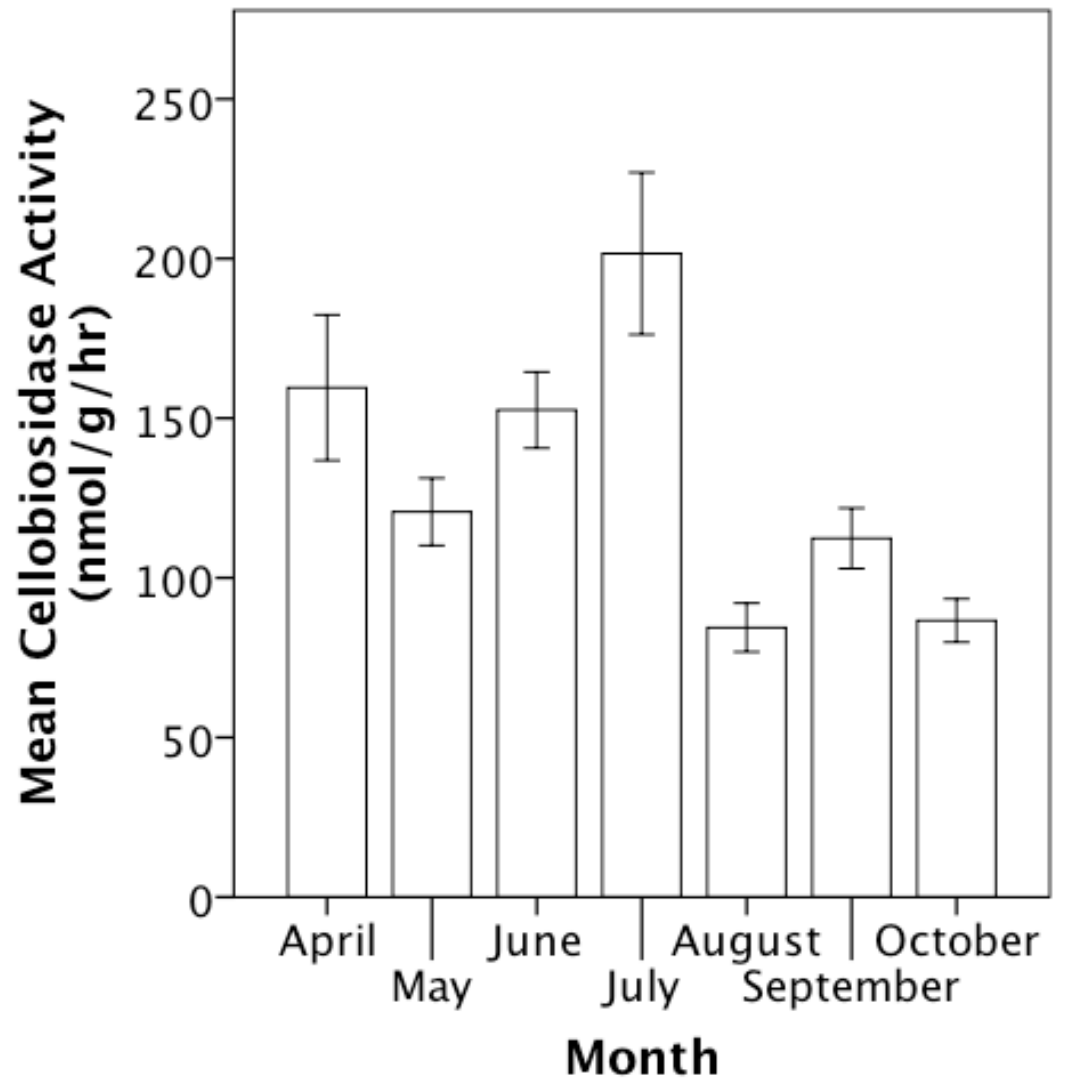

Figure 4.20 Mean cellobiosidase activity measured at $20^{\circ} \mathrm{C}$ varied significantly by month. Cellobiosidase activity was greatest in July and lower from August to October versus other months. Error bars are one standard error of the mean. 


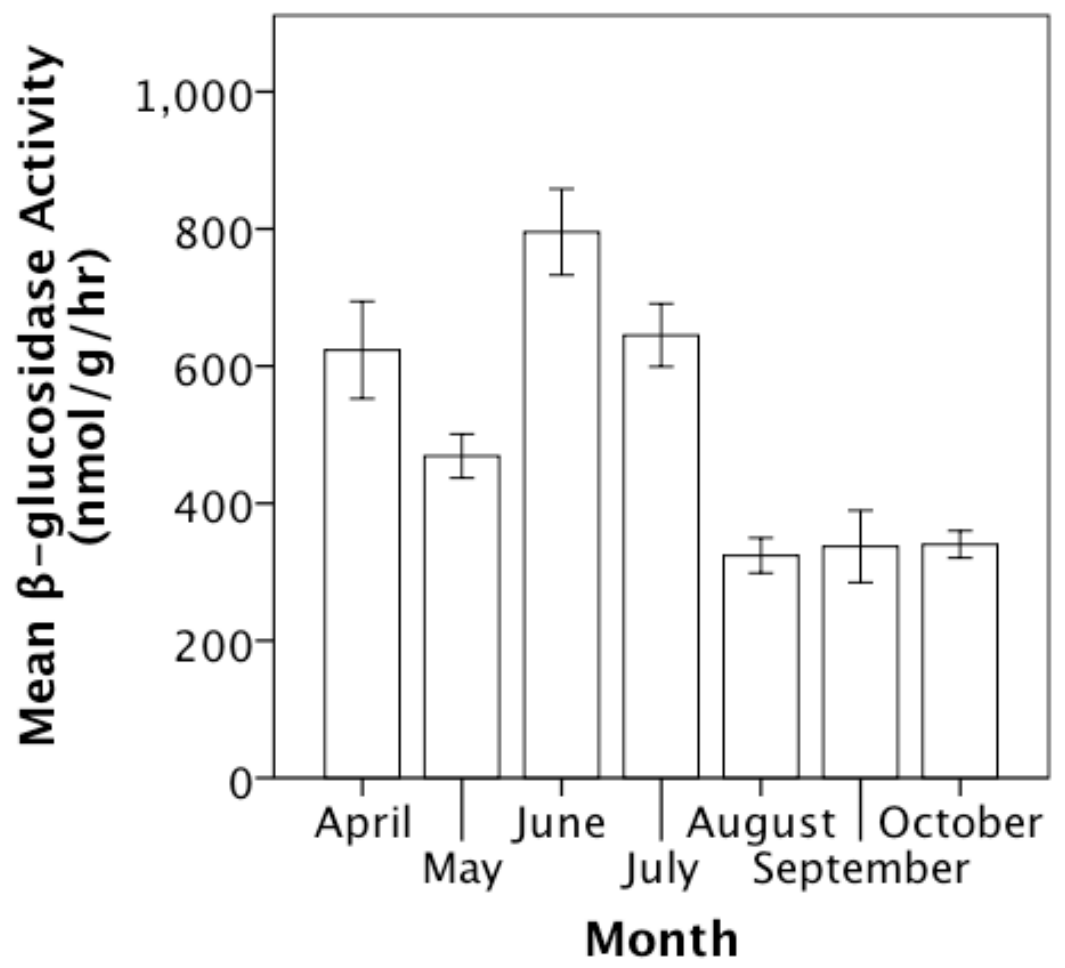

Figure 4.21 Mean $\beta$-glucosidase activity measured at $20^{\circ} \mathrm{C}$ varied significantly by month. Activity was higher in June and lower from August to October in comparison to other months. Error bars are one standard error of the mean. 


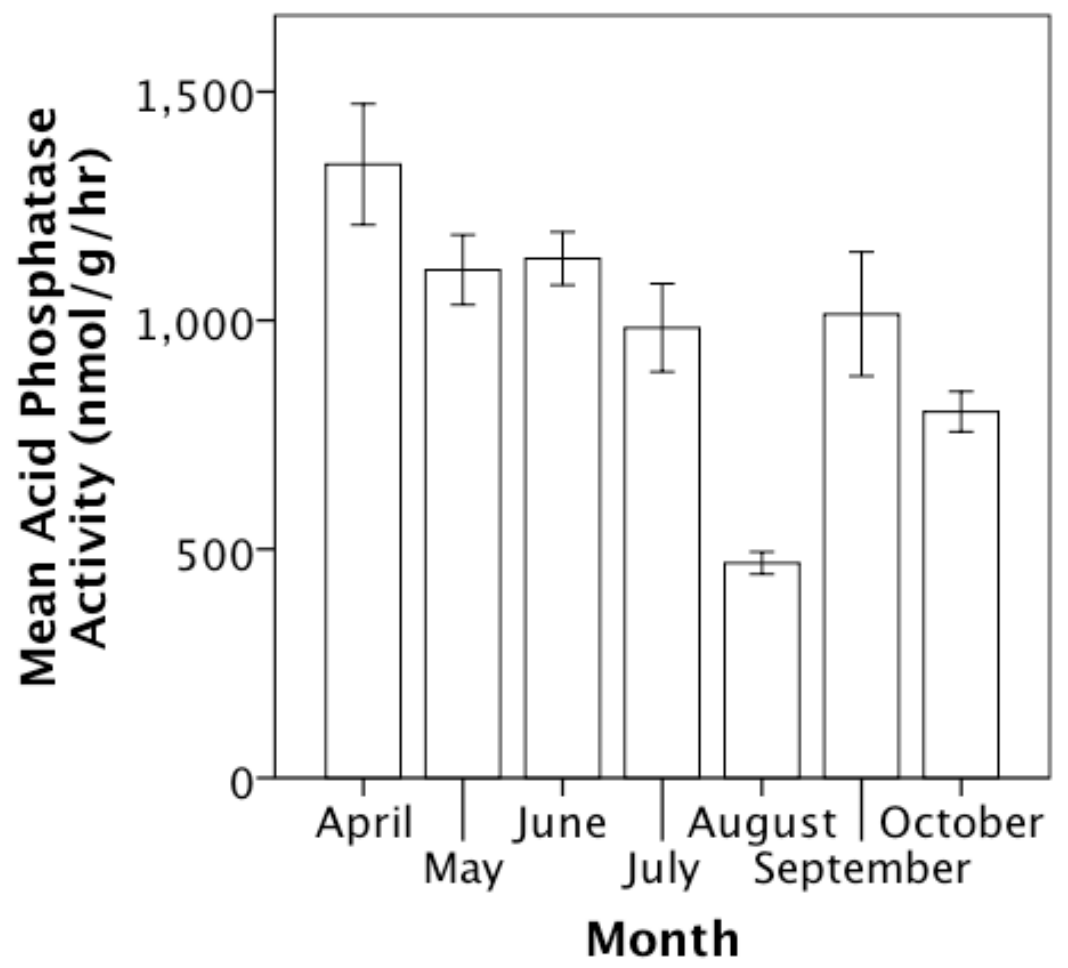

Figure 4.22 Mean acid phosphatase activity measured at $20^{\circ} \mathrm{C}$ varied significantly by month. Acid phosphatase activity decreased from April to August and then increased in September. Error bars are one standard deviation of the mean. 


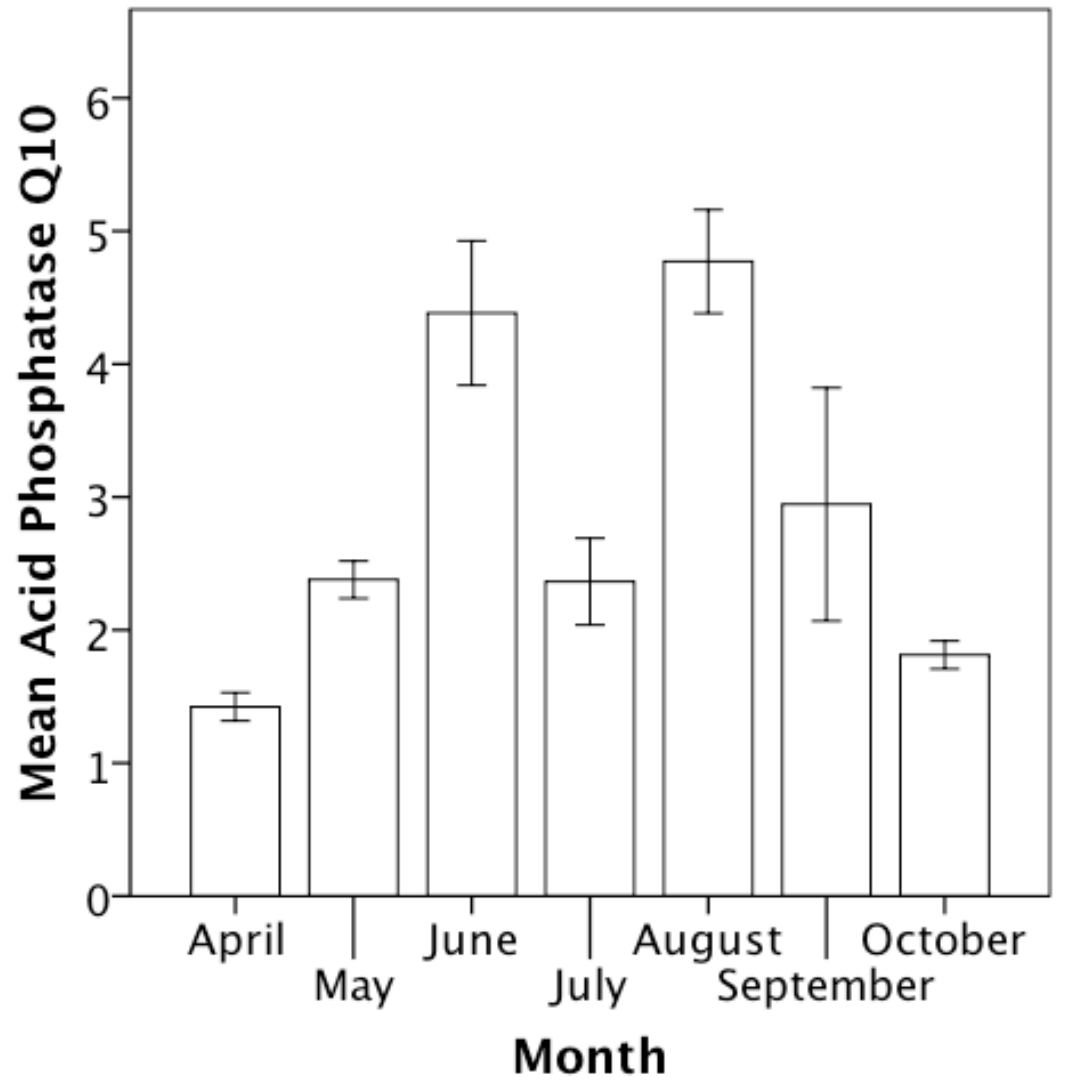

Figure 4.23 Mean acid phosphatase $\mathrm{Q}_{10}$ differed significantly by month. Acid phosphatase $\mathrm{Q}_{10}$ was greater in June and August than in other months. Error bars are one standard error of the mean. 


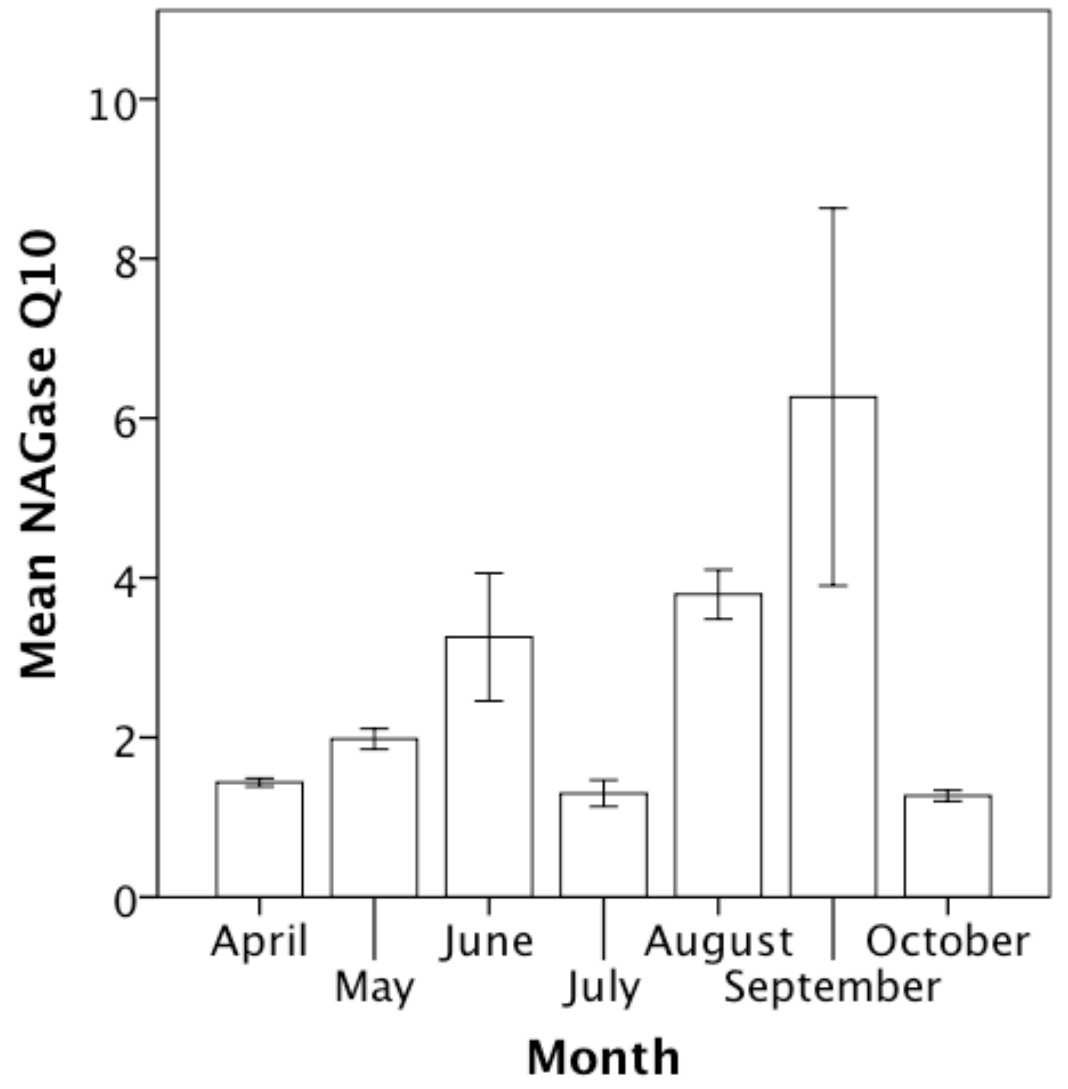

Figure 4.24 Mean NAGase $\mathrm{Q}_{10}$ differed significantly by month. NAGase $\mathrm{Q}_{10}$ was greater in September than in other months. Error bars are one standard error of the mean. 


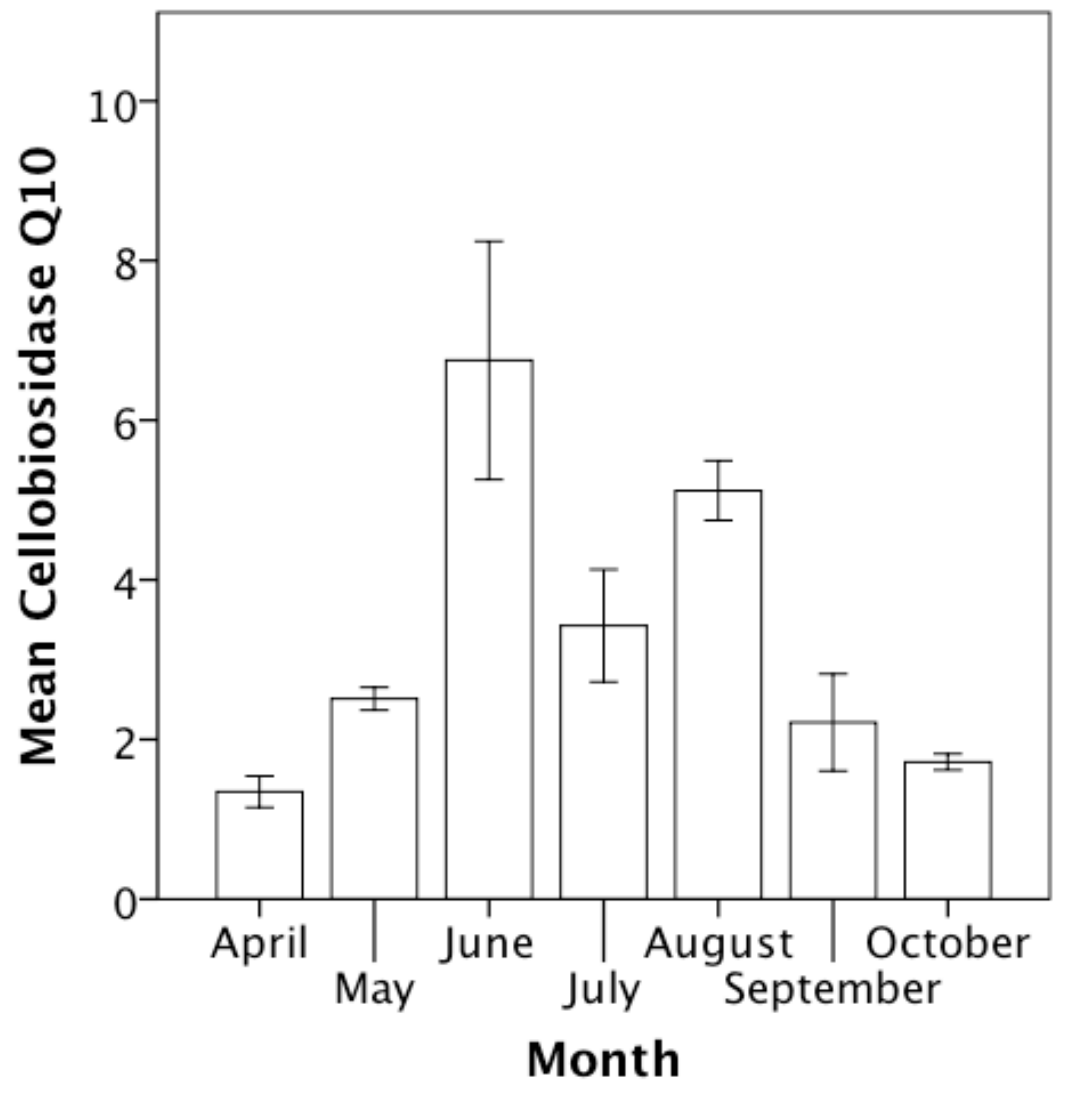

Figure 4.25 Mean Cellobiosidase $\mathrm{Q}_{10}$ differed significantly by month.

Cellobiosidase $\mathrm{Q}_{10}$ was higher from June to August compared to other months. Error bars are one standard error of the mean. 
103

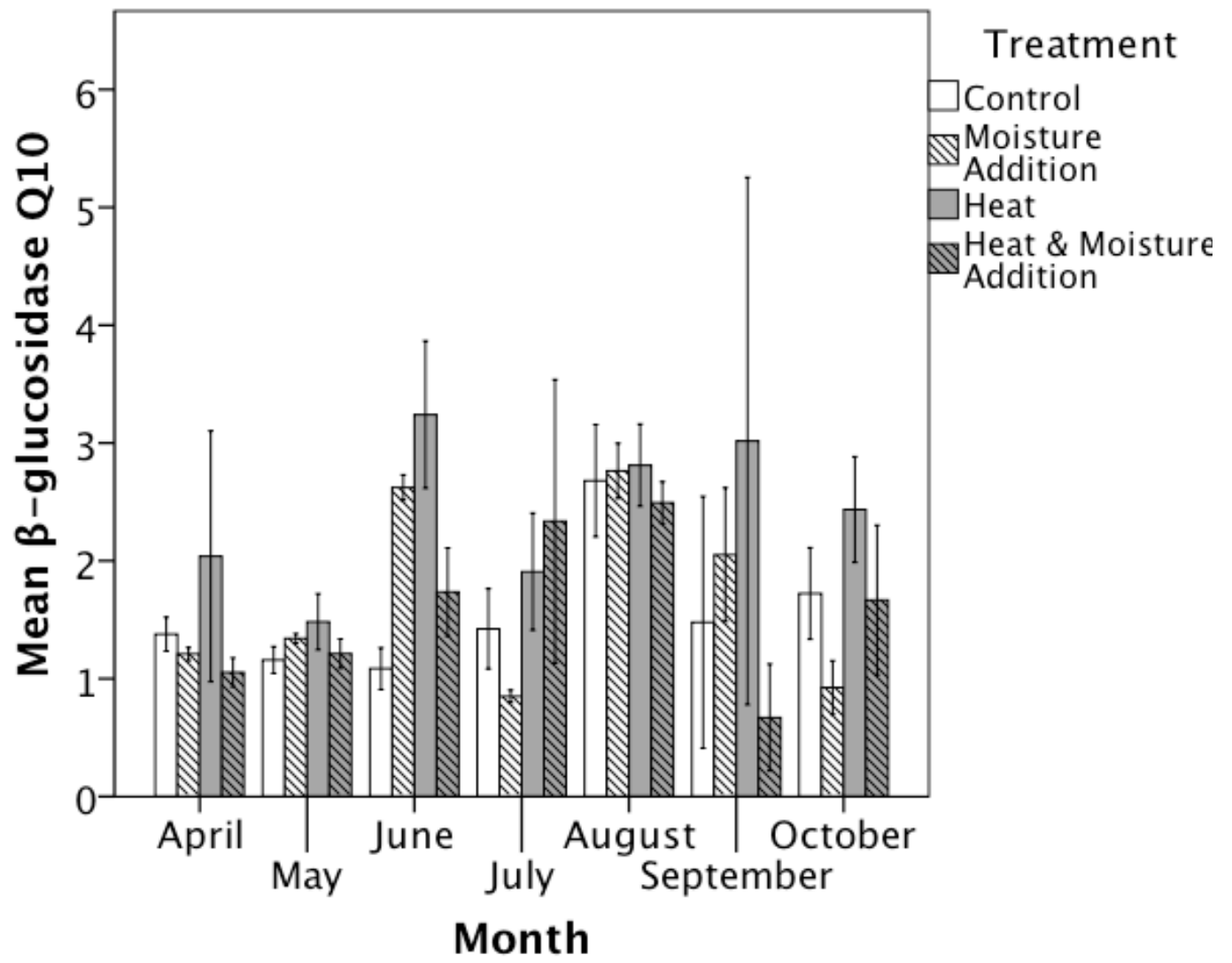

Figure 4.26 Mean $\beta$-glucosidase $\mathrm{Q}_{10}$ differed significantly by month. There was also a significant interaction between heat and moisture addition treatment. 


\subsection{References}

Allison, S.D. 2005. Cheaters, diffusion and nutrients constrain decomposition by microbial enzymes in spatially structured environments. Ecology Letters. 8: $626-635$.

Allison, S.D. and K.K. Treseder. 2008. Warming and drying suppress microbial activity and carbon cycling in boreal forest soils. Global Change Biology. 14: 2898-2909.

Arnold, S.S., Fernandez, I.J., Rustad, L.E. and L.M. Zibilske. 1999. Microbial response of an acid forest soil to experimental soil warming. Biology and Fertility of Soils. 30: 239-244.

Brooks, P.D., McKnight, D. and K. Elder. 2004. Carbon limitation of soil respiration under winter snowpacks: Potential feedbacks between growing season and winter carbon fluxes. Global Change Biology. 11: 231-238.

Burton, A.J., Jarvey, J.C., Jarvi, M.P., Zak, D.R., and K.S. Pregitzer. 2012. Chronic $\mathrm{N}$ alters root respiration-tissue $\mathrm{N}$ relationship in northern hardwood forests. Global Change Biology. 18: 258-266.

Bell, T.H., Klironomos, J.N. and H.A.L. Henry. 2010. Seasonal responses of extracellular enzyme activity and microbial biomass to warming and nitrogen addition. Soil Science Society of America Journal. 74: 820-828.

Christensen, J. H., Hewitson, B., Busuioc, A. et al. In: Climate Change 2007: The Physical Science Basis. Contribution of Working Group I to the Fourth Assessment Report of the Intergovernmental Panel on Climate Change. Solomon, S. et al. (eds.). Cambridge University Press: New York, New York, USA.

Clemente, J.S., Gregorish, E.G., Simpson, A.J., Kumar, R., Courtier-Murias, D. and M.J. Simpson. 2012. Comparison of nuclear magnetic resonance methods for the analysis of organic matter composition from soil density and particle fractions. Environmental Chemistry. 9: 97-107.

Fenner, N., Freeman, C. and B. Reynolds. 2005. Observations of a seasonally shifting thermal optimum in peatland carbon-cycling processes: Implications for the global carbon cycle and soil enzyme methodologies. Soil Biology and Biochemistry. 37: 1814-1821. 
Frey, S.D., Drijber, R., Smith, H. and J. Melillo. 2008. Microbial biomass, functional capacity, and community structure after 12 years of soil warming. Soil Biology and Biochemistry. 40: 2904-2907.

Frey, S.D., Lee, J., Melillo, J.M. and J. Six. 2013. The temperature response of soil microbial efficiency and its feedback to climate change. Nature Climate Change Letters. doi;10.1038/NCLIMATE1796.

German, D.P., Weintraub, M.N., Grandy, A.S., Lauber, C.L., Rinkes, Z.L. and S.D. Allison. 2011. Optimization of hydrolytic and oxidative enzyme methods for ecosystem studies. Soil Biology \& Biochemistry. 43(7): 1387-1397.

Kellner, H., Vandenbol, M. and D.R. Zak. 2010. Fungi unearthed: Transcripts encoding lignocelluloytic and chitinolytic enzymes in forest soils. PLoS ONE. 5: e10971. doi:10.1371/journal.pone.0010971.

Koch, O., Tscherko, D., E. Kandeler. 2007. Temperature sensitivity of microbial respiration, nitrogen mineralization, and potential soil enzyme activities in organic alpine soils. Global Biogeochemical Cycles. 21: GB4017, doi:10.1029/2007GB002983.

Luo et al. 2001 Luo, Y., Wan, S., Hui, D., Wallace, L.L., 2001. Acclimatization of soil respiration to warming in a tall grass prairie. Nature. 413: 622-624.

Meehl, G. A. et al. In: Climate Change 2007: The Physical Science Basis. Contribution of Working Group I to the Fourth Assessment Report of the Intergovernmental Panel on Climate Change. Solomon, S. et al. (eds.). Cambridge University Press: New York, New York, USA.

Oechel, W.C., Vourlitis, G.L., Hastings, S.J., Zulueta, R.C., Hinzman, L., Kane, D., 2000.Acclimation of ecosystem CO2 exchange in the Alaskan Artic in response to decadal climate warming. Nature. 406: 978-981.

Saiya-Cork, K.R., Sinsabaught, R.L. and D.R. Zak. 2002. The effects of long term nitrogen deposition on extracellular enzyme activity in an Acer saccharum forest soil. Soil Biology and Biochemistry. 34: 1309-1315.

Sardans, J. and J. Peñuelas. 2004. Drought decreases soil enzyme activity in a Mediterranean Quercus ilex L. forest. Soil Biology \& Biochemistry. 37: 455-461. 
Sinsabaugh, R.L., Gallo, M.E., Lauber, C., Waldrop, M.P. and D.R. Zak. 2005. Extracellular enzyme activities and soil organic matter dynamics for northern hardwood forests receiving simulated nitrogen deposition. Biogeochemistry. 75(2): 201-215.

Steinweg, J.M., Dukes, J.S. and M.D. Wallenstein. 2012. Modeling the effect of temperature and moisture on soil enzyme activity: Linking laboratory assays to continuous field data. Soil Biology and Biochemistry. 55: 85-92.

Weintraub, M.N., Scott-Denton, L.E., Schmidt, S.K. and R.K. Monson. 2007. The effects of tree rhizodeposition on soil exoenzyme activity, dissolved organic carbon, and nutrient availability in a subalpine forest ecosystem. Oecologia. 154: 327-338.

Yanai, Y., Toyota, K. and M. Okazaki. 2004. Effects of successive soil freeze-thaw cycles on soil microbial biomass and organic matter decomposition potential of soils. Soil Science and Plant Nutrition. 50: 821-829.

Yuste, J.C., Baldocchi, D.D., Gerhenson, A., Goldstein, A., Misson, L. and S. Wong. 2007. Microbial soil respiration and its dependency on carbon inputs, soil temperature and moisture. Global Change Biology. 13: 2018-2035. 


\section{Chapter 5: Microbial Biomass and Extracellular Enzyme Activities Show Seasonal Variability in an Experimental Climate Change Manipulation in a Temperate Hardwood Forest ${ }^{4}$}

\subsection{Abstract}

Climate change may impact soil microbial biomass and enzyme activity. Although a limited number of studies have examined the impact of soil warming on microbial biomass and enzyme activity, the majority of these studies have not been able to partition warming effects from concurrent soil drying in heated plots versus unheated plots. This study used a $2 \times 2$ fully factorial warming $\left(+4-5^{\circ} \mathrm{C}\right)$ and moisture addition ( $+30 \%$ average ambient growing season precipitation) experiment to examine the impact of increased soil temperature and elevated moisture inputs on microbial biomass and enzyme activity in the soil. When measured at the relevant treatment temperature $\left(15^{\circ} \mathrm{C}\right.$ for unheated plots and $20^{\circ} \mathrm{C}$ for heated plots) the majority of enzymes assayed showed higher activity in heated versus unheated plots. Although potential enzyme assays do not quantify the amount of enzyme present, we used the potential enzyme activity at a common incubation temperature as a surrogate for enzyme production. The production of oxidative enzymes in the soil may also be impacted by these treatments. $\mathrm{Q}_{10}$ of NAGase activity was greater in moisture addition treatments versus treatments lacking moisture addition. Microbial biomass, measured using chloroform fumigation extraction, did not differ with treatment. There were significant temporal effects on enzyme activity, $\mathrm{Q}_{10}$, and microbial biomass. Future research should focus on examining the quality and composition of organic matter present in these soils. This will aid understanding of

\footnotetext{
${ }^{4}$ Chapters $4 \& 5$ will be merged into a single article for publication in the journal Soil Biology and Biochemistry. Data from Chapter 6 will be used in this publication. The figures and text will be reformatted before submission. The order of authors for this article will be Carley Kratz, Erik Lilleskov and Andrew Burton. Carley Kratz, Andrew Burton and Erik Lilleskov have all contributed to the written portion of the text. The experimental site was overseen by Andrew Burton. Carley Kratz contributed to the methodological design and was responsible for collecting and processing data.
} 
the impact of climate change on soil carbon dynamics, addressing the underlying observations discussed in this study.

\subsection{Introduction}

It is now more certain than ever that global temperatures are rising and the climate is changing (IPCC including Christensen et al. 2007 and Meehl et al. 2007). As the climate continues to change, it becomes more urgent to understand how different ecosystem responses to altered temperature and precipitation may feed back into the climate system. Coupled earth systems models that link terrestrial biogeochemistry and climate models may need to be altered to account for these feedbacks (Mellilo et al. 2002). While soils are included in both regional and global climate change models, the mechanisms behind soil nutrient and carbon $(\mathrm{C})$ cycling are not well represented. Many of these models put soil processes into a "black box", and only use broad measurements, such as soil $\mathrm{CO}_{2}$ flux in calculations. The finescale mechanisms that lead to soil $\mathrm{CO}_{2}$ flux are often overlooked, however it is possible that these mechanisms will alter feedbacks to atmospheric $\mathrm{CO}_{2}$ and the climate. Understanding these specific mechanisms may be important to correctly predict climate trajectories.

Over 75.6 Pg of $\mathrm{C}$ are cycled through the soil every year, placing soil $\mathrm{C}$ inputs and outputs among the largest terrestrial C fluxes (Raich and Potter 1995). The increase in temperatures over the past half-century was accompanied by an increase in soil respiration (Bond-Lamberty and Thomson 2010), however the source of this increased C flux is unknown. Soil warming studies typically find that soil respiration adjusts to warming overtime (Oechel et al. 2000, Luo et al. 2001, Bradford et al. 2008). Soil respiration rates are elevated for the first few years of warming, but over time respiration rates decrease to a basal level similar to the rates that were present before warming was initiated. The initial increase in soil respiration may be related to higher root respiration, soil enzymatic capacity, increased availability of labile $\mathrm{C}$ substrates, or more rapid cycling of $\mathrm{C}$ in the soil. It has been suggested that over time soil respiration decreases as the labile carbon pool in the soil is depleted and/or microbial enzymatic capacity acclimates to higher 
temperatures. This apparent acclimation of soil respiration suppresses a possible positive feedback loop in which soil warming leads to higher soil $\mathrm{CO}_{2}$ flux to the atmosphere, causing additional warming of the atmosphere.

Soil microorganisms process the majority of soil carbon, however it remains unclear how soil microorganisms are impacted by climate change factors. Soil C in temperate forests is stored in microbial biomass, in recalcitrant forms such as lignin and humics, and to a small extent on the surface of soil particles. The most bioavailable forms of $\mathrm{C}$ are from microbial biomass and necromass. Microorganisms also immobilize soil $\mathrm{N}$ in the form of microbial biomass. Most temperate forests are $\mathrm{N}$ limited, and the microbial $\mathrm{N}$ pool can become an important source of $\mathrm{N}$ for plants, as some microbes transform organic $\mathrm{N}$ into a bioavailable species through metabolism. The ways in which microbial biomass $\mathrm{C}$ and $\mathrm{N}$ are impacted by climate change have been studied in a small number of soil warming experiments. Arnold et al. (1999) found that plots warmed $+5{ }^{\circ} \mathrm{C}$ tended to have lower microbial biomass in field soils from a spruce-fir forest, and that temperature was more important than moisture in regulating soil microbial biomass in an incubation study with the same soils. Frey et al. (2008) found that microbial biomass in a temperate hardwood forest soils decreased and that community composition shifted away from fungal dominance in response to long-term $+5{ }^{\circ} \mathrm{C}$ soil warming. Both of these studies show that warming can decrease microbial biomass and that temperature and moisture are inherently related in field soils.

Microorganisms in the soil produce many different types of hydrolytic and oxidative enzymes to degrade both labile and recalcitrant organic compounds. Soil enzymes associated with microbial decomposition of organic matter could be impacted by soil warming and climate change in a variety of different ways. Substrate availability, the amounts of enzymes produced, the $\mathrm{Km}$ or substrate affinity, and the Vmax of enzymes may be altered. Measuring the amount of substrate or quantity of a particular enzyme in the soil can be challenging. Some studies have examined the effect of soil warming on potential enzyme activity. Allison and Treseder (2008) found a large decrease in chitinase activity in a boreal 
forest with $0.5^{\circ} \mathrm{C}$ of warming. In a similar ecosystem, Allison et al. (2010) found that extracellular enzyme activities, including chitinase increased with warming of $1.2^{\circ} \mathrm{C}$. Bell et al. (2010) showed that potential extracellular activity of both hydrolytic and oxidative enzymes was unresponsive to temperature change however, there was seasonal variation in activity rates. These studies often have decreased soil moisture in heated versus un-heated plots (Allison and Treseder 2008, Arnold et al. 1999, Frey et al. 2008), making it difficult to determine if warming alone causes observed treatment effects. The study by Allison and Treseder (2008) had a $22 \%$ decrease in soil moisture in warmed versus control soils with only $0.5^{\circ} \mathrm{C}$ of warming. Arnold et al. 1999 found that dehydrogenase activity was related to soil moisture content, but not soil temperature at time of sampling. Some regions will receive less precipitation with climate change while others will receive more (Christensen et al. 2007, Meehl et al. 2007). It is therefore unrealistic to have consistently lower soil moisture in heated plots than unheated plots.

To address this issue we measured soil microbial $\mathrm{C}$ and $\mathrm{N}$ and potential enzyme activity in a mature northern hardwood forest receiving a factorial combination of soil warming and increased moisture inputs. These measurements were made after two years of experimental treatment applied during the growing season. The substrates selected for the enzyme assays represent a range of different organic compounds. Cellobiosidase is a hydrolytic exocellulase which cleaves the 1 , 4 bond between glucose molecules that make up cellulose polymers. This produces cellulose with 2 or 4 glucose constituents. $\beta$-glucosidase is a hydrolytic enzyme which cleaves the 1,4 bond between glucose molecules that make up cellulose, releasing free glucose molecules. Acid phosphate is a hydrolytic enzyme, which cleaves phosphate molecules from larger macromolecules. N-acetylglucosaminidase (NAGase) cleaves the 1,4 bond between the N-acetylglucosaminide molecules that make up chitin. Phenol oxidase and peroxidase both alter the structure of large macromolecules, such as lignin and humic acids. Both require oxygen as a terminal electron acceptor, and peroxidase also requires hydrogen peroxide. 
Based on past studies, higher temperature and lower moisture will change the microbial community in a way that negatively impacts biomass (Arnold et al. 1999, Frey et al. 2008). We hypothesized that warming would cause a decrease in soil microbial biomass $\mathrm{C}$ and $\mathrm{N}$, and an increase in the potential activity of soil enzymes. This would lead to a higher biomass-specific enzyme activity with higher temperatures. Moisture addition would cause an increase in microbial biomass and enzyme activity because moisture limitations would be eliminated. Plots receiving both heat and moisture will have the intermediate levels of microbial biomass and the greatest potential enzyme activity. Control plots will have the highest microbial biomass and lowest potential enzyme activity. These hypotheses suggest that both temperature and moisture limit enzyme activity. Monthly sampling was performed in this study in order to assess temporal variation in microbial biomass and enzyme activity. Many warming studies only take measurements at one time point in the year, however it has been demonstrated that microbial biomass and enzyme activity can change seasonally (Bell et al. 2010). We hypothesized that microbial biomass and enzyme activity would show temporal variation.

\subsection{Methods}

\section{Study Site}

A climate change manipulation experiment was initiated in September 2010 at the Ford Forestry Center in the Upper Peninsula of Michigan. Michigan Technological University's Ford Forestry Center is located at $46^{\circ} 38^{\prime} 26^{\prime \prime} \mathrm{N} 88^{\circ} 29^{\prime}$ $01 " \mathrm{~W}$ and $\sim 400 \mathrm{~m}$ elevation. Mean annual temperature in the area is $4.9^{\circ} \mathrm{C}$, with a growing season (May through September) average temperature of $15^{\circ} \mathrm{C}$. The area receives on average $879 \mathrm{~mm}$ of precipitation annually, with $401 \mathrm{~mm}$ of precipitation falling during the growing season (Burton et al. 2012). Sugar maple (Acer saccharum Marsh.) dominates the overstory (trees $>5.0 \mathrm{~cm}$ diameter), contributing to $89 \%$ of the overstory basal area. American elm (Ulmus americana L.), eastern hemlock (Tsuga canadensis (L.) Carr.), ironwood (Ostrya virginiana (Mill.) K. Koch) and yellow birch (Betula alleghaniensis Britton) comprise the remainder. Soils are Kallio cobbly silt loams (Coarse-loamy, mixed, superactive, frigid 
Oxyaquic Fragiorthods). This hardwood forest has been managed for sugar maple production and has not been thinned for over a decade.

The experiment has a $2 \times 2$ full factorial design with three blocks and no replicates within block, for a total of twelve plots. The treatment combinations include a control under ambient conditions, soil heating $\left(+4\right.$ to $\left.5^{\circ} \mathrm{C}\right)$, moisture addition ( $+30 \%$ of ambient average growing season precipitation) and soil heating plus moisture addition. Heating was achieved using infrared lamps suspended $1.5 \mathrm{~m}$ above the soil surface. There are twelve $10 \mathrm{~m}$ x $10 \mathrm{~m}$ plots in three blocks. Each block contains four plots, one from each experimental treatment. The moisture addition represents the upper limit of potential precipitation predicted by IPCC models (Chistensen et al. 2007), and in most years should replace any evaporative loss associated with the elevated temperature treatment. Precipitation was harvested from a rooftop catchment of a nearby building, stored in large holding tanks, and distributed approximately weekly onto plots using a sprinkler system. Moisture addition occurred during rain events when possible, in order to mimic natural patterns of precipitation. Treatments were only applied during the growing season. Enzyme Assays

Enzyme assays were conducted on soil slurries collected once per month during the growing season from March to October 2012. Three $5 \mathrm{~cm}$ diameter soil cores were selected at random from each plot. Soil cores were approximately $10 \mathrm{~cm}$ deep. Soil within each core was homogenized and roots, rocks and insects were removed prior to further analysis. Each of these samples was treated independently during laboratory analyses. Soil was transported on ice back to the laboratory immediately after sampling. Enzyme assays were conducted within 24 hours of soil collection. The enzymes assays were conducted according to Sinsabaugh et al. (2005). Approximately $1 \mathrm{~g}$ of fresh soil was added to $125 \mathrm{~mL}$ of $50 \mathrm{mM}$ sodium acetate buffer ( $\mathrm{pH}$ 5.0) and blended for $10 \mathrm{~s}$. A 96-well plate format was used. There were 16 technical replicates per sample. Each replicate contained $200 \mu \mathrm{L}$ of soil slurry and $50 \mu \mathrm{L}$ of substrate. Hydrolytic enzyme activity was estimated using $200 \mu \mathrm{M}$ fluorometric substrates including activities of acid phosphatase, $\beta$ - 
glucosidase, cellobiosidase and NAGase (chitinase). The hydrolytic enzyme assays included a blank with $250 \mu \mathrm{L}$ of buffer, a substrate correcting blank containing $200 \mu \mathrm{L}$ of buffer and $50 \mu \mathrm{L}$ of $200 \mu \mathrm{M}$ substrate, a quenching blank containing $200 \mu \mathrm{L}$ of buffer and $50 \mu \mathrm{L}$ of $10 \mu \mathrm{M}$ methylumbelliferone. Each of these had 8 technical replicates per plate. Additionally, there were 8 technical replicates containing $50 \mu \mathrm{L}$ of $10 \mu \mathrm{M}$ methylumeliferone and $200 \mu \mathrm{L}$ of soil slury for each sample to calculate the quenching coefficient. Oxidative enzyme activity was estimated using the L-DOPA substrate method to measure phenol oxidase and peroxidase activity. There were 16 technical replicates per sample, and 8 technical replicates for blanks including $250 \mu \mathrm{L}$ of buffer, $200 \mu \mathrm{L}$ of buffer and $50 \mu \mathrm{L}$ of 5 mM L-DOPA substrate, and $200 \mu \mathrm{L}$ of sample slurry with $50 \mu \mathrm{L}$ of buffer. The peroxidase assays also had $10 \mu \mathrm{L}$ of $1.0 \mathrm{M} \mathrm{H}_{2} \mathrm{O}_{2}$ added to each well. Duplicates of each sample were incubated at $15^{\circ} \mathrm{C}$ and $20^{\circ} \mathrm{C}$. Hydrolytic enzyme samples were incubated for 2 hours, and then $10 \mu \mathrm{L}$ of $1.0 \mathrm{M} \mathrm{NaOH}$ was added to each well in order to stop the reaction. Fluorescence was measured at an excitation of $364 \mathrm{~nm}$ and an emission wavelength of $450 \mathrm{~nm}$ using a SpectraMax M2 plate reader. Oxidative enzyme samples incubated for 24 hours and the absorbance was measured at $450 \mathrm{~nm}$. Enzyme activities were calculated according to German et al. 2011. Soil was dried at $60^{\circ} \mathrm{C}$ for at least 24 hours to obtain the dry weight. In order to determine potential extracellular enzyme activity rates in the field, activities were analyzed by treatment temperature. For the activity by treatment results the $20^{\circ} \mathrm{C}$ incubation activities are reported for samples from heated plots, and the $15^{\circ} \mathrm{C}$ incubation activities are reported for samples from the control and moisture addition plots. This was done to mimic the average soil temperatures in the field. Results of all activities at the common temperatures of $15^{\circ} \mathrm{C}$ and $20^{\circ} \mathrm{C}$ are also reported, along with biomass-specific potential enzyme activity rates and $\mathrm{Q}_{10}$.

\section{Microbial Biomass}

Chloroform fumigation extractions were performed to obtain microbial biomass $\mathrm{C}$ and $\mathrm{N}$ estimates (Horwath and Paul 1994). Subsamples of $10 \mathrm{~g}$ of each sample were used for fumigated and unfumigated replicates. For fumigations, 36 
soil samples were placed into $50 \mathrm{~mL}$ glass beakers in a desiccator with a beaker containing $20 \mathrm{~mL}$ of ethanol-free chloroform and boiling chips. A vacuum was pulled and released 5 times, allowing the chloroform to boil each time, and then the samples were left under a vacuum in the dark for 3 days. Excess chloroform was removed by vacuum. Samples were removed and then extracted with $50 \mathrm{~mL}$ of 2.0 $\mathrm{M} \mathrm{KCl}$ for one hour. The extract was then filtered through a borosilicate glass fiber filter and frozen until further analysis. Unfumigated samples were extracted in a similar manner as above. The quantity of total dissolved carbon and nitrogen was measured in 1:10 dilutions of these extracts using a Shimadzu TOC-V analyzer. The amount of inorganic $\mathrm{N}$ was quantified using a Perstorp 3550 EnviroFlow rapid flow analyzer to measure both ammonia and nitrate.

Statistical Anlaysis

Statistical analyses were conducted using SPSS version 21.0 and $\mathrm{R}$ (http://cran.us.r-project.org). Data was pooled at the plot level for analysis. Residuals were tested for normality and were normally distributed. Two outliers were found and not used in calculations of mean enzyme activity for each plot. Although there were some issues with unequal variance the large and equal sample size allowed us to use repeated measures ANOVA tests; however it should be noted that the unequal variances increase the chance of a type I error. ANOVA tests were conducted with potential enzyme activity, microbial biomass $\mathrm{C}$, microbial biomass $\mathrm{N}, \mathrm{Q}_{10}$, and biomass-specific enzyme activity as dependent variables. $\mathrm{Q}_{10}$ values were not analyzed for the oxidative enzymes because there were many instances in which no activity was detected. Independent variables included treatment, block and month. The effect of block, heat, water and interaction between heat and water was determined between subjects. Within subjects effects were tested for month, month by block interaction, month by heat interaction, month by water interaction and a three-way interaction between month, heat and water. Alpha was set at 0.05 . 


\subsection{Results}

\section{Enzyme Activity}

Treatment effects were present for cellobiosidase when enzyme activities were analyzed by the incubation temperature relevant to field temperatures (Table 5.1). The month of sampling had a significant impact on all enzymes that were assayed. Figure 5.1 shows that cellobiosidase activity was approximately $10 \%$ higher in heated versus unheated treatments. There was also a significant interaction of heat and moisture on cellobiosidase activity. Acid phosphatase and NAGase activity had significant month by heat interactions when activity at relevant field temperatures were analyzed (Table 5.1). Acid phosphatase activity was generally greater in heated versus unheated treatments for all months, with the exception of June and October, where heated treatments had lower activity than the unheated treatments (Figure 5.2). Acid phosphatase activity was approximately $15 \%$ greater in heated versus unheated plots in September, the month with the greatest difference between treatments. NAGase activity was 30\% higher in the heated treatments versus unheated treatments in April, however in June and August heated treatments had 10\% lower activity than unheated treatments (Figure 5.3). There was a significant block effect on cellobiosidase and phenol oxidase activity (Table 5.1). Figure 5.4 shows that cellobiosidase activity was approximately $10 \%$ lower in block 3 versus other blocks. Phenol oxidase activity also exhibited a significant interaction between month and block (Figure 5.5). Phenol oxidase activity was nearly 40\% higher in March versus other months. Cellobiosidase and $\beta$-glucosidase activities were lowest in April and June and highest in August (Figures 5.6 and 5.7). From April to August cellobiosidase activity increased by $60 \%$ and $\beta$-glucosidase activity increase by $50 \%$. Peroxidase activity was nearly $80 \%$ greater in March versus other months (Figure 5.8).

When enzyme activities were compared at the $15^{\circ} \mathrm{C}$ incubation temperature for all samples (Table 5.2) there was a significant heat by month interaction for phenol oxidase activity (Figure 5.9). There were no other significant treatment effects. All enzymes assayed had significantly different activity by month. Heated 
treatments had approximately $25 \%$ greater phenol oxidase activity than unheated treatments from March to May, and this pattern was reversed from July to September. There was also a significant block effect on phenol oxidase activity and a significant block by month interaction (Figure 5.10). Block 1 tended to have greater activity than other blocks except for in August and September.

Cellobiosidase (Figure 5.11), $\beta$-glucosidase (Figure 5.12), and acid phosphatase (Figure 5.13) activities all tended to be lowest in April and June. Cellobiosidase (Figure 5.11) and $\beta$-glucosidase (Figure 5.12) activities were highest in August and acid phosphatase activity (Figure 5.13) was greatest in September, increasing seasonally by $20 \%, 50 \%$ and $75 \%$ respectively. NAGase activity was relatively low through the beginning of the season, but was 75\% higher in April versus all other months (Figure 5.14). Peroxidase activity was not detected in September and was $75 \%$ lower in October than other months (Figure 5.15).

When enzyme activities were compared at the $20^{\circ} \mathrm{C}$ incubation temperature for all samples (Table 5.3) peroxidase was the only enzyme assayed which showed significant treatment effects. All enzyme activities varied significantly by month. There was a significant effect of heat treatment, water treatment, and month with significant interactions between heat and water, month and block (Figure 5.16), and a significant three-way interaction between month, heat and water (Figure 5.17) on peroxidase activity. Heated treatments tended to have lower peroxidase activity than unheated treatments. Moisture addition tended to have higher peroxidase activity, particularly in March where the activity was approximately $80 \%$ higher in the moisture addition treatment compared to the activity of any treatment in other months. Phenol oxidase activity was $20 \%$ greater in block 1 versus other blocks (Figure 5.18) and the opposite pattern was present in peroxidase activity (Figure 5.16). Cellobiosidase (Figure 5.19) and $\beta$-glucosidase (Figure 5.20) activities were lowest in April and June and greatest in August, increasing seasonally by approximately $60 \%$ and $50 \%$, respectively. Acid phosphatase activity was also lowest in June, increasing by approximately 50\% through the growing season (Figure 5.21). NAGase activity was low in June as well as in March, with the 
greatest activity in April, increasing by approximately 80\% from March to April (Figure 5.22). Phenol oxidase (Figure 5.23) activity was 60\% greater in March versus other months.

Microbial Biomass

Microbial biomass $\mathrm{C}$ and $\mathrm{N}$ did not differ by treatment, but did differ significantly by month (Table 5.4). Microbial biomass $\mathrm{C}$ was approximately $30 \%$ lower in July and August than in other months (Figure 5.24). Microbial biomass N decreased from March to May and then increased in June, with a subsequent decrease in August (Figure 5.25). Microbial biomass N increased by approximately $50 \%$ from May to June.

Biomass-Specific Enzyme Activity

Biomass-specific enzyme activity only showed a significant treatment effect for peroxidase, where there was a significant treatment by month interaction (Table 5.5). July had $70 \%$ lower peroxidase activity in the heated versus unheated treatments (Figure 5.26). The biomass-specific peroxidase activity was approximately $60 \%$ greater in July versus other months. There was also a significant effect of month on biomass-specific acid phosphatase activity (Figure 5.27). Biomass-specific acid phosphatase activity was approximately $60 \%$ lower from March to June than from July to October.

$\underline{\mathrm{Q}_{10}}$

There no significant direct treatment effects on $\mathrm{Q}_{10}$ for any enzymes assayed (Table 5.6). All four hydrolytic enzymes had $\mathrm{Q}_{10}$ values that varied significantly by month. NAGase $\mathrm{Q}_{10}$ showed a significantly interaction between month and moisture addition treatment, and three-way interaction between month, moisture addition and heat treatment (Figure 5.29). NAGase $\mathrm{Q}_{10}$ was approximately 10\% lower in plots with moisture addition versus plots without moisture addition (Figure 5.28). NAGase $\mathrm{Q}_{10}$ was approximately $75 \%$ lower in June versus other months. $\beta$-glucosidase $\mathrm{Q}_{10}$ varied significantly by month, generally being around 1.75 , but decreasing by approximately 10\% in March and June (Figure 5.30). Cellobiosidase $\mathrm{Q}_{10}$ increased by $50 \%$ from March to July and then decreased, ranging from 1 to 2 (Figure 5.31). 
Acid phosphatase $\mathrm{Q}_{10}$ tended to increase throughout the season ranging from 1 to 2 (Figure 5.32). Acid phosphatase $\mathrm{Q}_{10}$ also showed a significant month by block interaction (Table 5.6).

\subsection{Discussion}

\section{Enzyme Activity}

Carbon, nitrogen and phosphorus are cycled more rapidly when soils are warmed in this temperate forest ecosystem. When measured at relevant treatment temperature, enzyme activity rates were $30-60 \%$ greater in heated versus unheated plots for three of the four hydrolytic enzymes. This is likely due to higher rates of chemical reactions mediated by soil enzymes and enhanced diffusivity of substrates with soil warming (Allison 2005, Koch et al. 2007). Cellobiosidase activity was significantly higher in heated versus unheated treatments, and there were significant month by heat interactions for acid phosphatase and NAGase. There was a nonsignificant trend for lower activities in the control versus other treatments for all four hydrolytic enzymes. This supports our hypothesis that increased temperature and moisture addition would lead to higher enzyme activity rates, and is in accordance with the results of a soil warming study in a spruce-fir forest (Arnold et al. 1999).

Oxidative enzymes also showed significant treatment or treatment by month interactions. At the common temperature of $15^{\circ} \mathrm{C}$ peroxidase activity was higher in in moisture addition treatments versus treatments lacking moisture addition, suggesting that more peroxidase may be produced when more moisture is available. Peroxidase requires oxygen to function, but peroxide must also be present. It is possible that the increased soil moisture in this case allowed peroxide to diffuse through the soil more easily, causing more peroxidase enzymes to be produced (Allison 2005). Peroxidase activity was also higher in heated versus unheated treatments, supporting this conjecture. At the common measurement temperature of $20^{\circ} \mathrm{C}$ phenol oxidase activity showed a significant month by heat interaction, and heated treatments generally had higher activity than unheated treatments. This lends further support to our hypothesis that potential enzyme activity increases at elevated temperature and with increased moisture inputs. This may be due to increased 
production of oxidative enzymes in heated plots. It is possible that these enzymes are produced to break down more recalcitrant organic compounds as more labile substrates become limited. Waldrop and Firestone (2004) also found that oxidative enzyme activity increased at elevated temperatures in tropical forest soils. More information on the composition of the organic matter in the soil will help to determine if less labile substrates are available on heated plots compared to unheated plots.

The enzyme activity measured at each temperature was significantly different between months, agreeing with the results from Chapter 4 and previously published studies in other ecosystems (Bell et al. 2010). The input of simple carbohydrate sources to the soil varies throughout the year and with the weather, so it is not surprising that we found significant temporal differences for all enzymes assayed. Changes in litter inputs or root exudates could have an impact on enzyme activity, although we did not test that directly here. $\beta$-glucosidase and cellobiosidase both break down simple carbohydrates, and the activity of these enzymes followed a similar temporal pattern. Activity was lowest in April and greatest during the late summer near August. This may have been due to increased input of carbohydrates from roots, including exudates and root turnover in the soil. It is unclear why NAGase activity was elevated in April. NAGase breaks down chitin, aiding N acquisition. The activity of acid phosphatase is tied to phosphorus (P) acquisition. There is probably a tight $\mathrm{P}$ cycle in this temperate forest, so most of the available $\mathrm{P}$ comes from leaf and root litter inputs (Barnes et al. 1998). It is possible that, as the growing season progresses, less of this $\mathrm{P}$ is available as the litter from the past fall is decomposed. More acid phosphatase enzymes could be produced in order to obtain more $\mathrm{P}$. This would result in higher acid phosphatase rates as the growing season progressed into the fall.

Microbial Biomass

There were no significant differences in microbial biomass by treatment. This result is contrary to our hypothesis that heated plots would have lower microbial biomass than unheated plots and that moisture addition plots would have higher 
microbial biomass than plots without moisture addition. Most studies have found that estimates of microbial biomass $\mathrm{C}$ decrease with warming (Frey et al. 2008, Arnold et al. 1999), although these studies used methods other than chloroform fumigation extraction to estimate microbial biomass C. Frey et al. (2008) used phospholipid fatty acid analysis (PLFA), which only measures the C content of the cellular membranes. A shift in the microbial community may change the amount of carbon contained in the cellular membranes, however other carbon containing structures, such as spores are not fully accounted for in PLFA analysis. Arnold et al. (1999) used substrate-induced respiration (SIR) to estimate microbial biomass. The SIR method measures the amount of $\mathrm{CO}_{2}$ flux from the soil after addition of a simple carbohydrate, such as glucose. This is not a direct measurement of biomass, but can be useful in determining potential activity of active microbial biomass.

The previous studies also had long-term manipulations lasting over a decade, but this study was conducted during the second season of warming. It is possible that given a longer time period the microbial biomass $\mathrm{C}$ might decrease significantly in the warmed plots of this study as well. Overtime, labile substrate may be lost, causing the microbial biomass to decrease with warming. A smaller microbial biomass may also have greater specific activity, allowing the available substrate to be processed at a similar or faster rate in heated versus unheated plots. In time, the $\mathrm{C}$ inputs from plants will limit the amount of substrate available.

Microbial biomass $\mathrm{C}$ and $\mathrm{N}$ both varied significantly according to month. This is in line with other studies that have examined microbial biomass over time (Bell et al. 2010, Schindlbacher et al. 2011). It is interesting to note that microbial biomass $\mathrm{N}$ was highest in June; just before microbial biomass $\mathrm{C}$ was lowest in July and August. It is possible that the relatively high $\mathrm{N}$ content of the microbial biomass in June led to a quick turnover of the microbial biomass as a whole. This may have occurred if $\mathrm{N}$ became a limiting resource and the microbial biomass was degraded by other soil organisms in order to obtain N. This would explain why the microbial biomass $\mathrm{C}$ and $\mathrm{N}$ were both lower in subsequent months. Given these results we expected increases in the $\mathrm{N}$ acquiring enzyme NAGase in June or July, but no link 
between the $\mathrm{N}$ acquiring enzyme NAGase and microbial biomass $\mathrm{N}$ is apparent in this study.

\section{Biomass-Specific Enzyme Activity}

There were no significant differences among treatments for biomass-specific hydrolytic enzyme activities. Peroxidase specific activity showed a significant month by heat interaction. Heated treatments tended to have lower specific peroxidase activity than unheated treatments suggesting that the organisms producing peroxidase enzymes may have adjusted to the warming treatment by reducing the amount of enzyme produced per unit biomass.

The biomass-specific enzyme activity is a function of both microbial biomass and potential enzyme activity. It is therefore not surprising that the temporal patterns found in potential enzyme activity were lost when microbial biomass was taken into account. When specific enzyme activity was calculated only two of the enzymes assayed, acid phosphatase and peroxidase, showed significant temporal variation. The biomass-specific activity of acid phosphatase still increased as the growing season progressed, however there was a large jump in specific activity in July, which was sustained throughout the remainder of the growing season. This is likely tied to the relatively low microbial biomass $\mathrm{C}$ in July and the following months. Following this pattern, peroxidase specific activity was also highest in July, but decreased in the fall.

$\underline{\mathrm{Q}_{10}}$

None of the enzymes assayed had significant variation according to treatment alone. NAGase showed significant interactions between treatment and month of sampling. NAGase $\mathrm{Q}_{10}$ was lower in the moisture addition treatments versus treatments without moisture addition. Although this difference was not significant, this suggests that the activity of the NAGase enzymes present in the moisture addition treatments is less sensitive to changes in temperature than treatments that lack added moisture. It is important to note that our $\mathrm{Q}_{10}$ results only apply to $\mathrm{Q}_{10}$ between $15^{\circ} \mathrm{C}$ and $20^{\circ} \mathrm{C}$, typical temperatures for the majority of the growing 
season from late spring to early fall. $\mathrm{Q}_{10}$ would likely be different if higher or lower measurement temperatures were used.

The temperature sensitivity, or $\mathrm{Q}_{10}$, of potential enzyme activities differed significantly by month for all hydrolytic enzymes. The temperature sensitivity of soil enzymes is dependent on the temperature of the soil throughout the season (Fenner et al. 2005). The $\mathrm{Q}_{10}$ of $\beta$-glucosidase, cellobiosidase and acid phosphatase were low in March. This indicates that the enzyme activity is not very sensitive to temperature changes between $15^{\circ} \mathrm{C}$ and $20^{\circ} \mathrm{C}$ at the beginning of the growing season. It is possible that the activity early in the spring represents the activity of constitutive enzymes, which are produced regularly to satiate the maintenance of microbial cells. The activity of these enzymes may not be as flexible as enzymes produced later in the growing season, when temperature, moisture and nutrient concentrations are more variable. It is also possible that psychrophilic microorganisms produce these enzymes and these enzymes, which are not stable at higher temperatures (Feller and Gerday 2003). Acid phosphatase $\mathrm{Q}_{10}$ was greatest in October, which was also a month with high acid phosphatase activity. Acid phosphatase enzymes may be more sensitive to changes in temperature later in the growing season. More data on soil $\mathrm{P}$ concentrations will allow us to determine if there is a link between $\mathrm{P}$ availability and the function of acid phosphatases.

\subsection{Conclusion}

Our results generally support our hypothesis that elevated temperature and higher moisture inputs would increase enzyme activity in the field. This suggests that carbon, nitrogen and phosphorus are cycled more rapidly at soil higher temperatures. Additionally, the production of oxidative enzymes may be sensitive to elevated temperature and moisture inputs. If labile carbon and nutrients are cycled more rapidly in warmed soils, soil microorganisms may produce more oxidative enzymes in order to break down recalcitrant carbon compounds to obtain nutrient and energy sources. Contrary to our hypothesis, microbial biomass did not show a significant response to treatments. The $\mathrm{Q}_{10}$ enzyme activities did not show significant responses to changes in temperature or moisture, although there were 
significant interactions between month of sampling and treatment for NAGase activity. Higher $\mathrm{Q}_{10}$ of NAGase activity in drier soils may have large implications for soil nitrogen cycling, since NAGase breaks down chitin molecules that contain nitrogen. There was temporal variation in enzyme activity, microbial biomass and $Q_{10}$. This is likely related to seasonal variation of inputs of organic matter to the soil. More information on the microbial community structure and the composition of organic matter in the soil will help us to understand the mechanisms driving these patterns and ultimately improve soil biogeochemical and terrestrial ecosystem models. 
Table 5.1 Results of repeated measures ANOVA for enzyme activity rates according to relevant treatment temperature. Alpha was set at alpha $=0.05$, and $p$ values are shown. Significant p-values are bolded.

\begin{tabular}{lllllllllll} 
& Block & Heat & Water & $\begin{array}{l}\text { Heat } \mathbf{x} \\
\text { Water }\end{array}$ & Month & $\begin{array}{l}\text { Month } \\
\mathbf{x} \\
\text { Block }\end{array}$ & $\begin{array}{l}\text { Month } \\
\mathbf{x} \text { Heat }\end{array}$ & $\begin{array}{l}\text { Month } \\
\mathbf{x} \\
\text { Water }\end{array}$ & $\begin{array}{l}\text { Month } \\
\mathbf{x} \text { Heat } \\
\mathbf{x} \\
\text { Water }\end{array}$ \\
\hline Cellobiosidase & $\mathbf{0 . 0 2 1}$ & $\mathbf{0 . 0 3 9}$ & 0.288 & $\mathbf{0 . 0 2 4}$ & $<\mathbf{0 . 0 0 1}$ & 0.829 & 0.130 & 0.144 & 0.430 \\
\hline $\boldsymbol{\beta}$-glucosidase & 0.170 & 0.073 & 0.862 & 0.149 & $<\mathbf{0 . 0 0 1}$ & 0.531 & 0.193 & 0.226 & 0.314 \\
\hline $\begin{array}{l}\text { Acid } \\
\text { Phosphatase }\end{array}$ & 0.336 & 0.072 & 0.154 & 0.357 & $<\mathbf{0 . 0 0 1}$ & 0.714 & $<\mathbf{0 . 0 0 1}$ & 0.109 & 0.086 \\
\hline NAGase & 0.119 & 0.803 & 0.255 & 0.711 & $<\mathbf{0 . 0 0 1}$ & 0.772 & $<\mathbf{0 . 0 0 1}$ & 0.220 & 0.145 \\
\hline Phenol oxidase & $\mathbf{0 . 0 3 5}$ & 0.191 & 0.601 & 0.412 & $\mathbf{< 0 . 0 0 1}$ & $<\mathbf{0 . 0 0 1}$ & 0.379 & 0.936 & 0.600 \\
\hline Peroxidase & 0.496 & 0.561 & 0.972 & 0.425 & $<\mathbf{0 . 0 0 1}$ & 0.897 & 0.999 & 1.00 & 0.848
\end{tabular}

Table 5.2 Results of repeated measures ANOVA for enzyme activity rates at $15^{\circ} \mathrm{C}$. Alpha was set at alpha $=0.05$, and $p$-values are shown. Significant $p$-values are bolded.

\begin{tabular}{|c|c|c|c|c|c|c|c|c|c|}
\hline & Block & Heat & Water & $\begin{array}{l}\text { Heat } x \\
\text { Water }\end{array}$ & Month & $\begin{array}{l}\text { Month } \\
\text { x } \\
\text { Block }\end{array}$ & $\begin{array}{l}\text { Month } \\
\text { x Heat }\end{array}$ & $\begin{array}{l}\text { Month } \\
\text { x } \\
\text { Water }\end{array}$ & $\begin{array}{l}\text { Month } \\
\text { x Heat } \\
\text { x } \\
\text { Water }\end{array}$ \\
\hline Cellobiosidase & 0.164 & 0.479 & 0.396 & 0.355 & 0.004 & 0.836 & 0.229 & 0.401 & 0.470 \\
\hline$\beta$-glucosidase & 0.094 & 0.070 & 0.943 & 0.352 & $<0.001$ & 0.740 & 0.408 & 0.417 & 0.767 \\
\hline $\begin{array}{l}\text { Acid } \\
\text { Phosphatase }\end{array}$ & 0.472 & 0.348 & 0.283 & 0.426 & $<0.001$ & 0.751 & 0.939 & 0.830 & 0.767 \\
\hline NAGase & 0.206 & 0.305 & 0.242 & 0.965 & $<0.001$ & 0.662 & 0.163 & 0.080 & 0.130 \\
\hline Phenol oxidase & 0.003 & 0.092 & 0.782 & 0.716 & $<0.001$ & 0.002 & 0.031 & 0.825 & 0.387 \\
\hline Peroxidase & 0.550 & 0.056 & 0.508 & 0.186 & $<0.001$ & 0.544 & 0.424 & 0.114 & 0.231 \\
\hline
\end{tabular}

Table 5.3 Results of repeated measures ANOVA for enzyme activity rates at $20^{\circ} \mathrm{C}$. Alpha was set at alpha $=0.05$, and $p$-values are shown. Significant $p$-values are bolded.

\begin{tabular}{|c|c|c|c|c|c|c|c|c|c|}
\hline & Block & Heat & Water & $\begin{array}{l}\text { Heat } x \\
\text { Water }\end{array}$ & Month & $\begin{array}{l}\text { Month } \\
\text { x } \\
\text { Block }\end{array}$ & $\begin{array}{l}\text { Month } \\
\text { x Heat }\end{array}$ & $\begin{array}{l}\text { Month } \\
\mathbf{x} \\
\text { Water }\end{array}$ & $\begin{array}{l}\text { Month } \\
\text { x Heat } \\
\text { x } \\
\text { Water }\end{array}$ \\
\hline Cellobiosidase & 0.083 & 0.053 & 0.659 & 0.194 & $<0.001$ & 0.768 & 0.405 & 0.561 & 0.706 \\
\hline$\beta$-glucosidase & 0.157 & 0.099 & 0.774 & 0.183 & $<0.001$ & 0.716 & 0.489 & 0.575 & 0.235 \\
\hline $\begin{array}{l}\text { Acid } \\
\text { Phosphatase }\end{array}$ & 0.474 & 0.417 & 0.457 & 0.665 & $<0.001$ & 0.561 & 0.268 & 0.066 & 0.318 \\
\hline NAGase & 0.131 & 0.349 & 0.441 & 0.887 & $<0.001$ & 0.685 & 0.133 & 0.565 & 0.278 \\
\hline Phenol oxidase & 0.039 & 0.503 & 0.108 & 0.324 & $<0.001$ & 0.075 & 0.377 & 0.112 & 0.272 \\
\hline Peroxidase & 0.024 & $<0.001$ & 0.031 & 0.013 & 0.004 & 0.047 & 0.349 & 0.058 & 0.004 \\
\hline
\end{tabular}


Table 5.4 Results of repeated measures ANOVA for microbial biomass. Alpha was set at alpha $=0.05$, and $p$-values are shown. Significant $p$-values are bolded.

\begin{tabular}{lcccccccccc} 
& Block & Heat & Water & $\begin{array}{l}\text { Heat } \\
\text { Water }\end{array}$ & Month & $\begin{array}{l}\text { Month } \\
\mathbf{x} \\
\text { Block }\end{array}$ & $\begin{array}{l}\text { Month } \\
\mathbf{x} \text { Heat }\end{array}$ & $\begin{array}{l}\text { Month } \\
\mathbf{x} \\
\text { Water }\end{array}$ & $\begin{array}{l}\text { Month } \\
\mathbf{x} \text { Heat } \\
\mathbf{x} \\
\text { Water }\end{array}$ \\
$\begin{array}{l}\text { Microbial } \\
\text { Biomass C }\end{array}$ & 0.165 & 0.305 & 0.517 & 0.216 & $<\mathbf{0 . 0 0 1}$ & 0.435 & 0.282 & 0.388 & 0.183 \\
\hline $\begin{array}{l}\text { Microbial } \\
\text { Biomass N }\end{array}$ & 0.532 & 0.215 & 0.744 & 0.368 & $<\mathbf{0 . 0 0 1}$ & 0.210 & 0.353 & 0.537 & 0.757 \\
\hline
\end{tabular}

Table 5.5 Results of repeated measures ANOVA for biomass-specific enzyme activity at relevant treatment temperature. Alpha was set at alpha $=0.05$, and $p$-values are shown. Significant $\mathrm{p}$-values are bolded.

\begin{tabular}{llllllllll} 
& Block & Heat & Water & $\begin{array}{l}\text { Heat } \mathbf{x} \\
\text { Water }\end{array}$ & Month & $\begin{array}{l}\text { Month } \\
\mathbf{x} \\
\text { Block }\end{array}$ & $\begin{array}{l}\text { Month } \\
\mathbf{x} \text { Heat }\end{array}$ & $\begin{array}{l}\text { Month } \\
\mathbf{x} \\
\text { Water }\end{array}$ & $\begin{array}{l}\text { Month } \\
\mathbf{x} \text { Heat } \\
\mathbf{x} \\
\text { Water }\end{array}$ \\
\hline Cellobiosidase & 0.543 & 0.299 & 0.310 & 0.387 & 0.197 & 0.582 & 0.385 & 0.521 & 0.621 \\
\hline $\begin{array}{l}\boldsymbol{\beta} \text {-glucosidase } \\
\text { Acid }\end{array}$ & 0.536 & 0.331 & 0.339 & 0.412 & 0.234 & 0.533 & 0.271 & 0.442 & 0.537 \\
\hline $\begin{array}{l}\text { Phosphatase } \\
\text { NAGase }\end{array}$ & 0.172 & 0.112 & 0.086 & 0.767 & $<\mathbf{0 . 0 0 1}$ & 0.901 & 0.060 & 0.676 & 0.272 \\
\hline Phenol oxidase & 0.514 & 0.346 & 0.311 & 0.367 & 0.322 & 0.510 & 0.443 & 0.477 & 0.534 \\
\hline Peroxidase & 0.281 & 0.083 & 0.386 & 0.376 & $<\mathbf{0 . 0 0 1}$ & 0.941 & $\mathbf{0 . 0 2 0}$ & 0.780 & 0.694
\end{tabular}

Table 5.6 Results of repeated measures ANOVA for $\mathrm{Q}_{10}$. Alpha was set at alpha $=0.05$, and $p$-values are shown. Significant $p$-values are bolded.

\begin{tabular}{lccccccccc} 
& Block & Heat & Water & $\begin{array}{l}\text { Heat } \mathbf{x} \\
\text { Water }\end{array}$ & Month & $\begin{array}{l}\text { Month } \\
\mathbf{x} \\
\text { Block }\end{array}$ & $\begin{array}{l}\text { Month } \\
\mathbf{x} \text { Heat }\end{array}$ & $\begin{array}{l}\text { Month } \\
\mathbf{x} \\
\text { Water }\end{array}$ & $\begin{array}{l}\text { Month } \\
\mathbf{x} \text { Heat } \\
\mathbf{x} \\
\text { Water }\end{array}$ \\
\hline Cellobiosidase & 0.417 & 0.212 & 0.182 & 0.750 & $<\mathbf{0 . 0 0 1}$ & 0.385 & 0.273 & 0.906 & 0.114 \\
\hline $\begin{array}{l}\beta \text {-glucosidase } \\
\text { Acid }\end{array}$ & 0.401 & 0.655 & 0.780 & 0.295 & $\mathbf{0 . 0 1 3 7}$ & 0.561 & 0.834 & 0.132 & 0.122 \\
\hline $\begin{array}{l}\text { Phosphatase } \\
\text { NAGase }\end{array}$ & 0.082 & 0.644 & 0.549 & 0.201 & $<\mathbf{0 . 0 0 1}$ & $\mathbf{0 . 0 0 6}$ & 0.480 & 0.138 & 0.063 \\
\hline
\end{tabular}




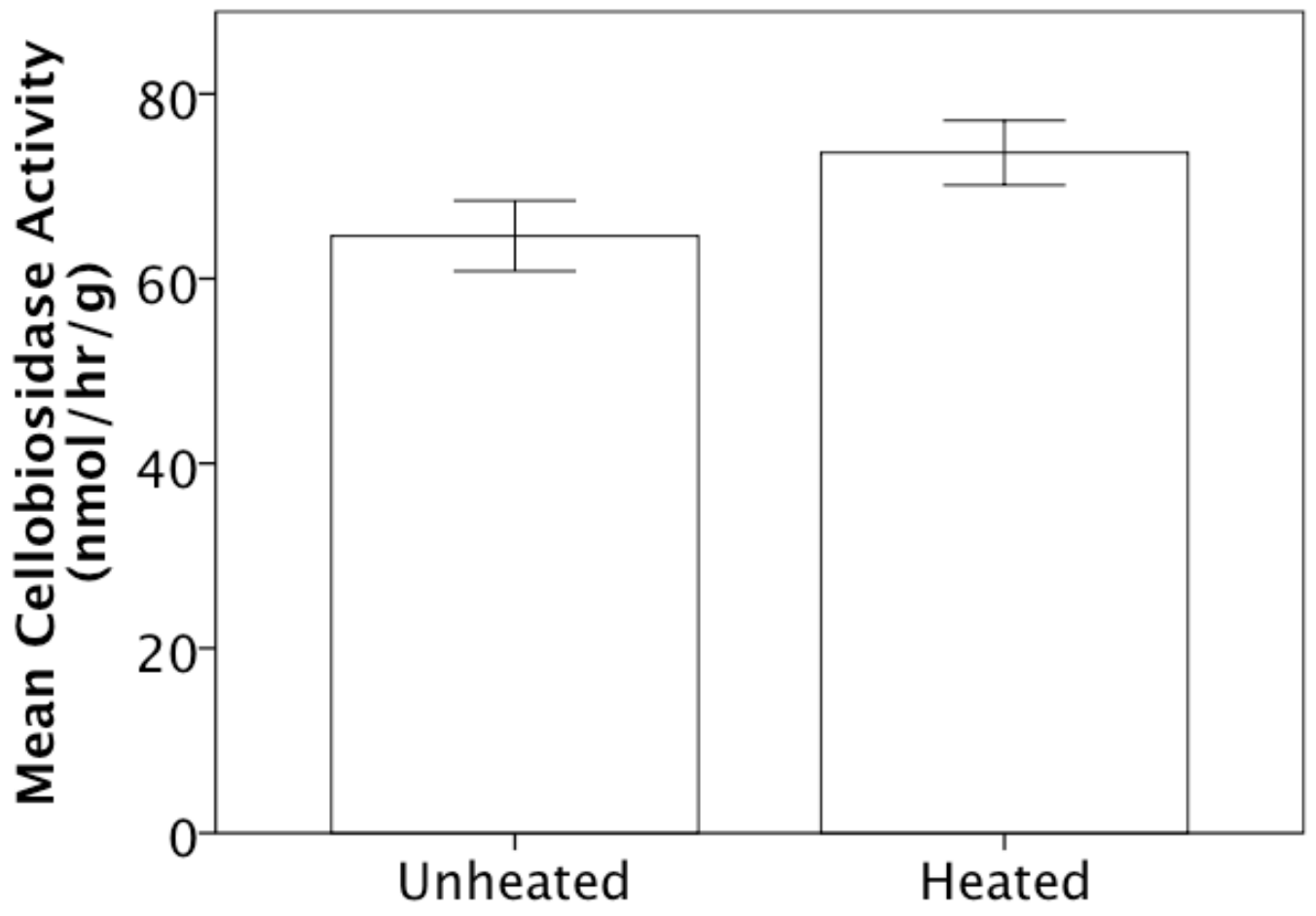

Figure 5.1 Mean cellobiosidase activity at relevant treatment temperature was significantly greater in the heated versus unheated treatments. Error bars are one standard error of the mean. 


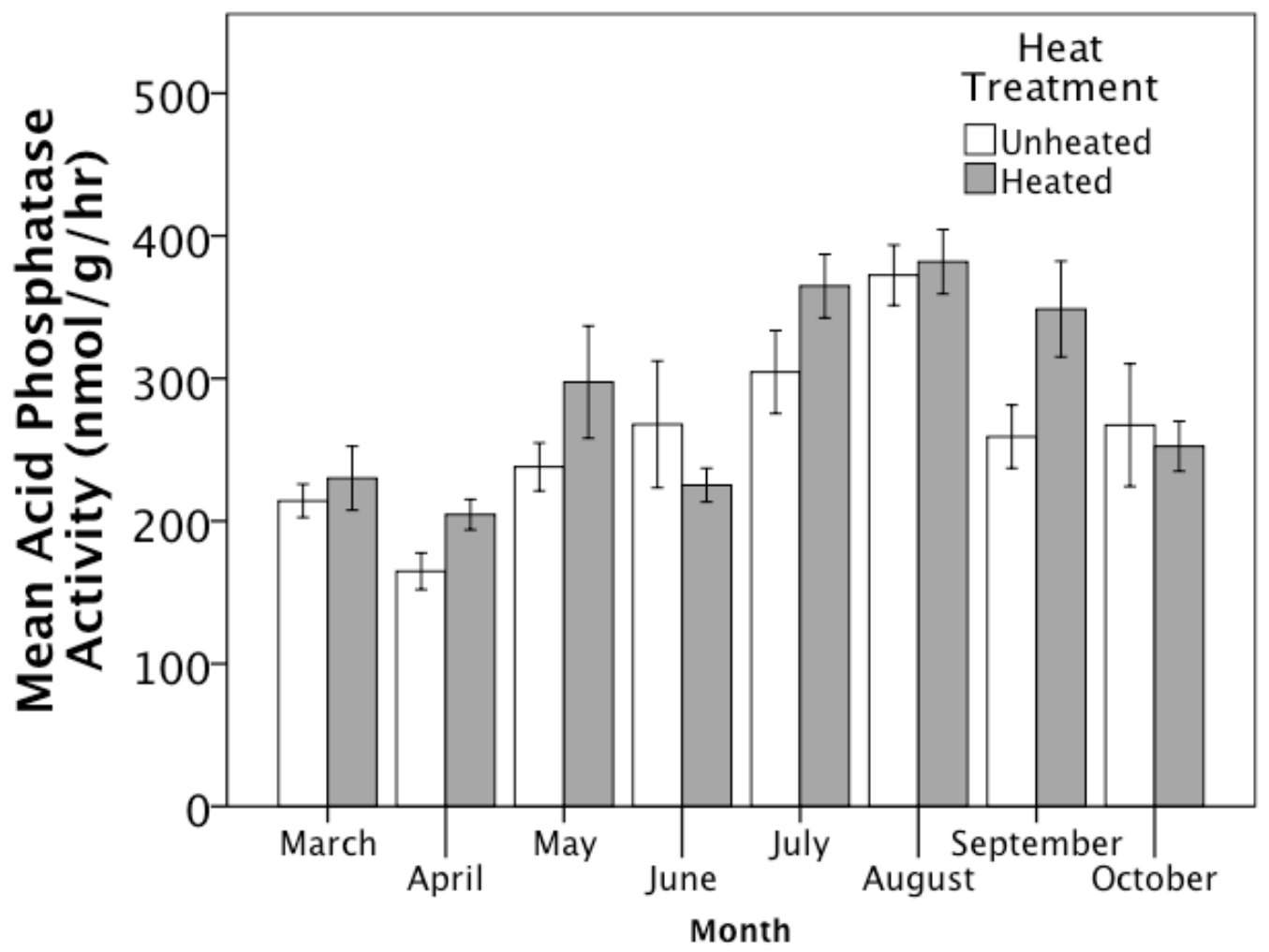

Figure 5.2 Mean acid phosphatase activity at relevant treatment temperature showed a significant interaction between month and heat treatment, and varied significantly by month. Error bars are one standard error of the mean. 


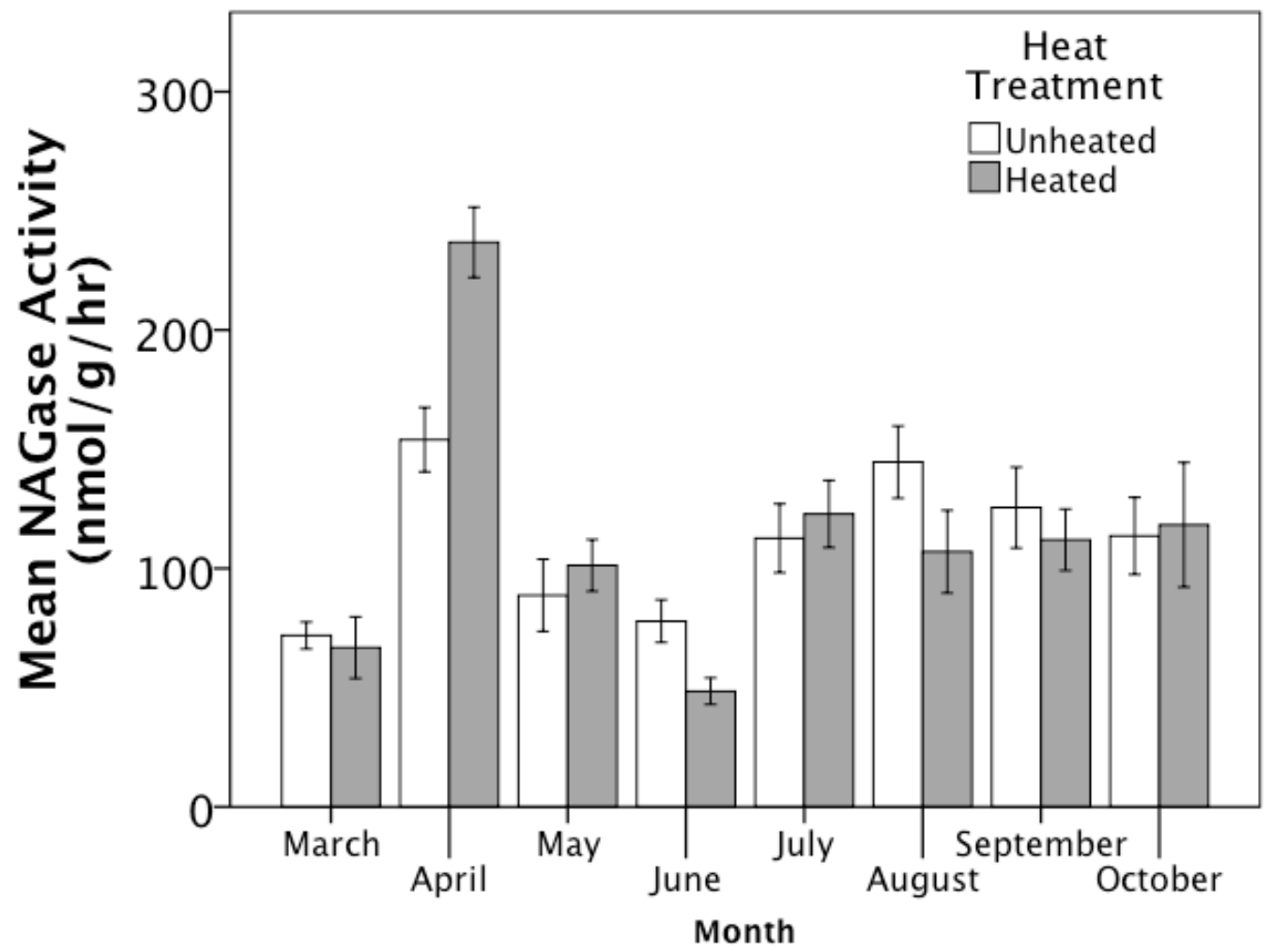

Figure 5.3 Mean NAGase activity at relevant treatment temperature showed a significant interaction between month and heat treatment, and varied significantly by month. Error bars are one standard error of the mean. 


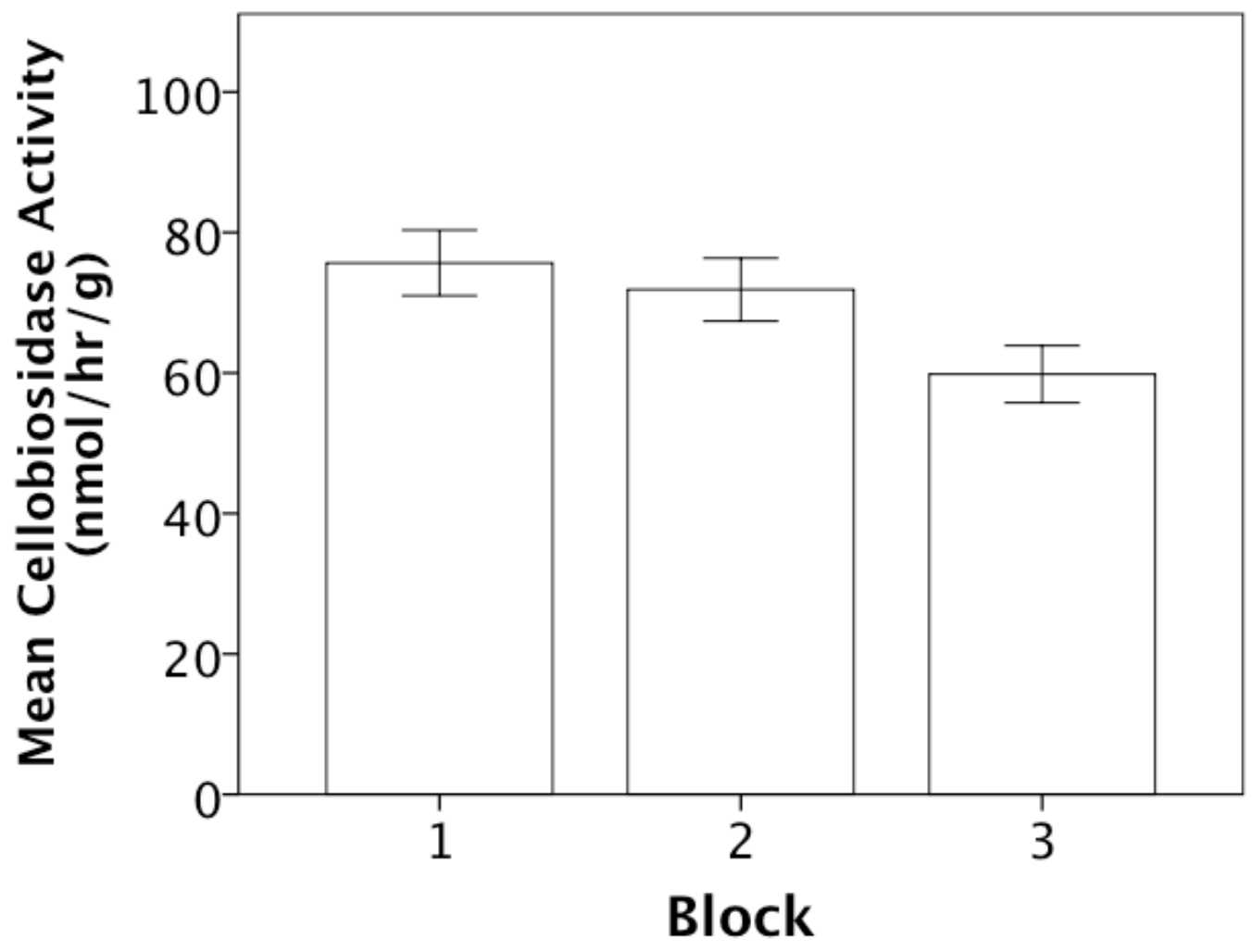

Figure 5.4 Mean cellobiosidase activity at relevant treatment temperature varied significantly by block. Error bars are one standard error of the mean. 


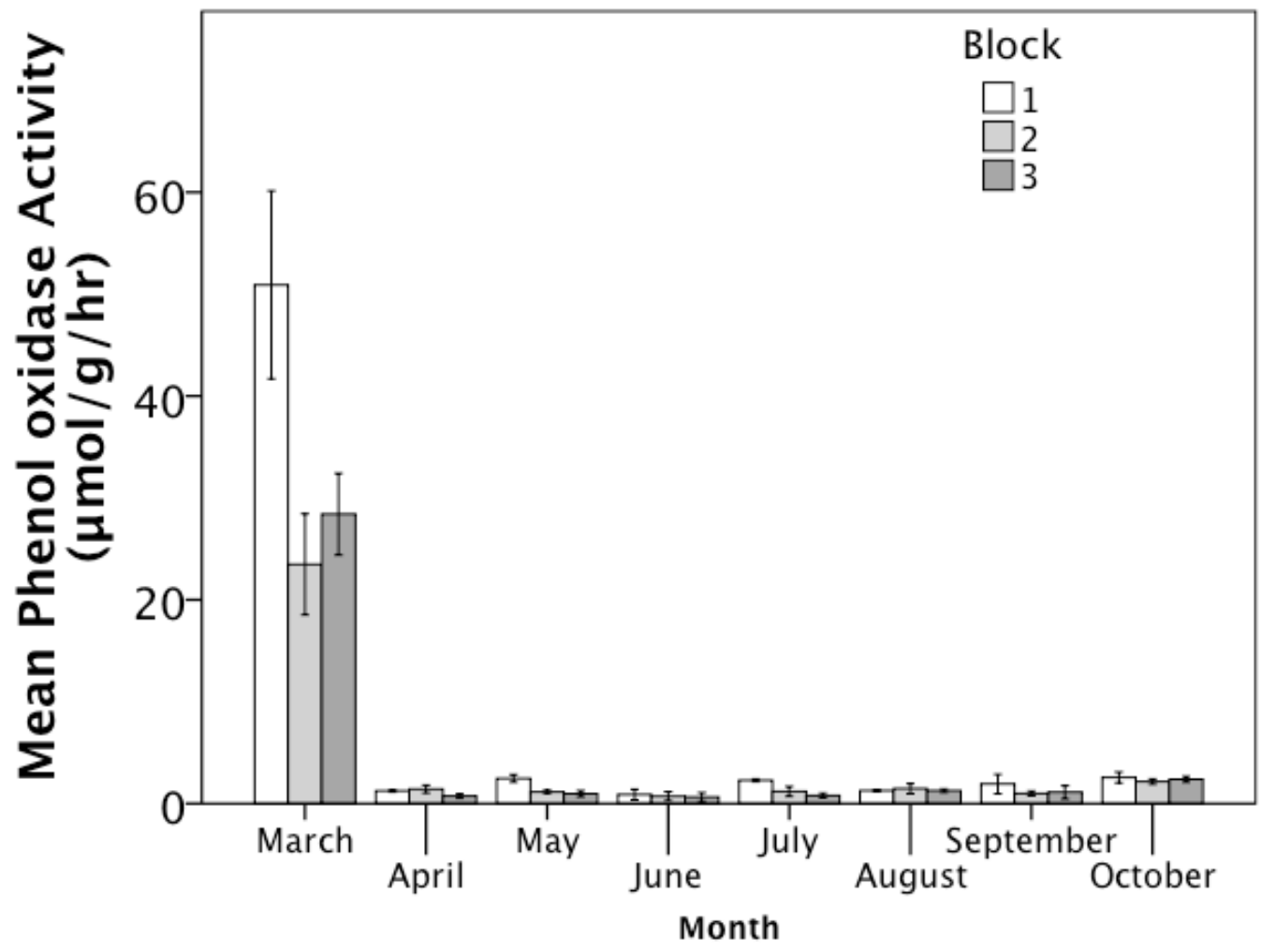

Figure 5.5 Mean phenol oxidase at relevant treatment temperature activity varied significantly by month and showed a significant interaction between month and block. Error bars are one standard error of the mean. 


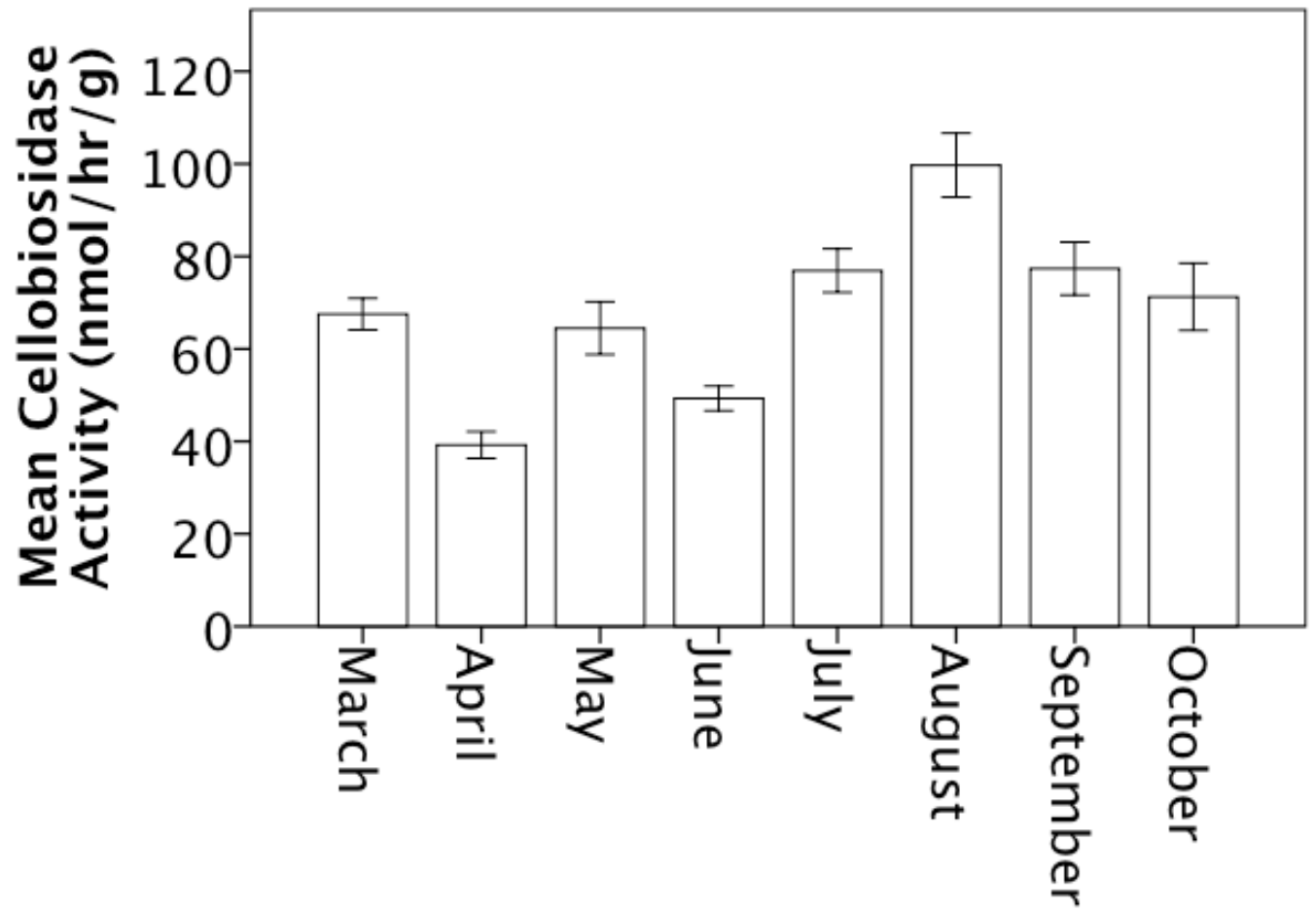

Month

Figure 5.6 Mean cellobiosidase activity at relevant treatment temperature varied significantly by month. Error bars are one standard error of the mean. 


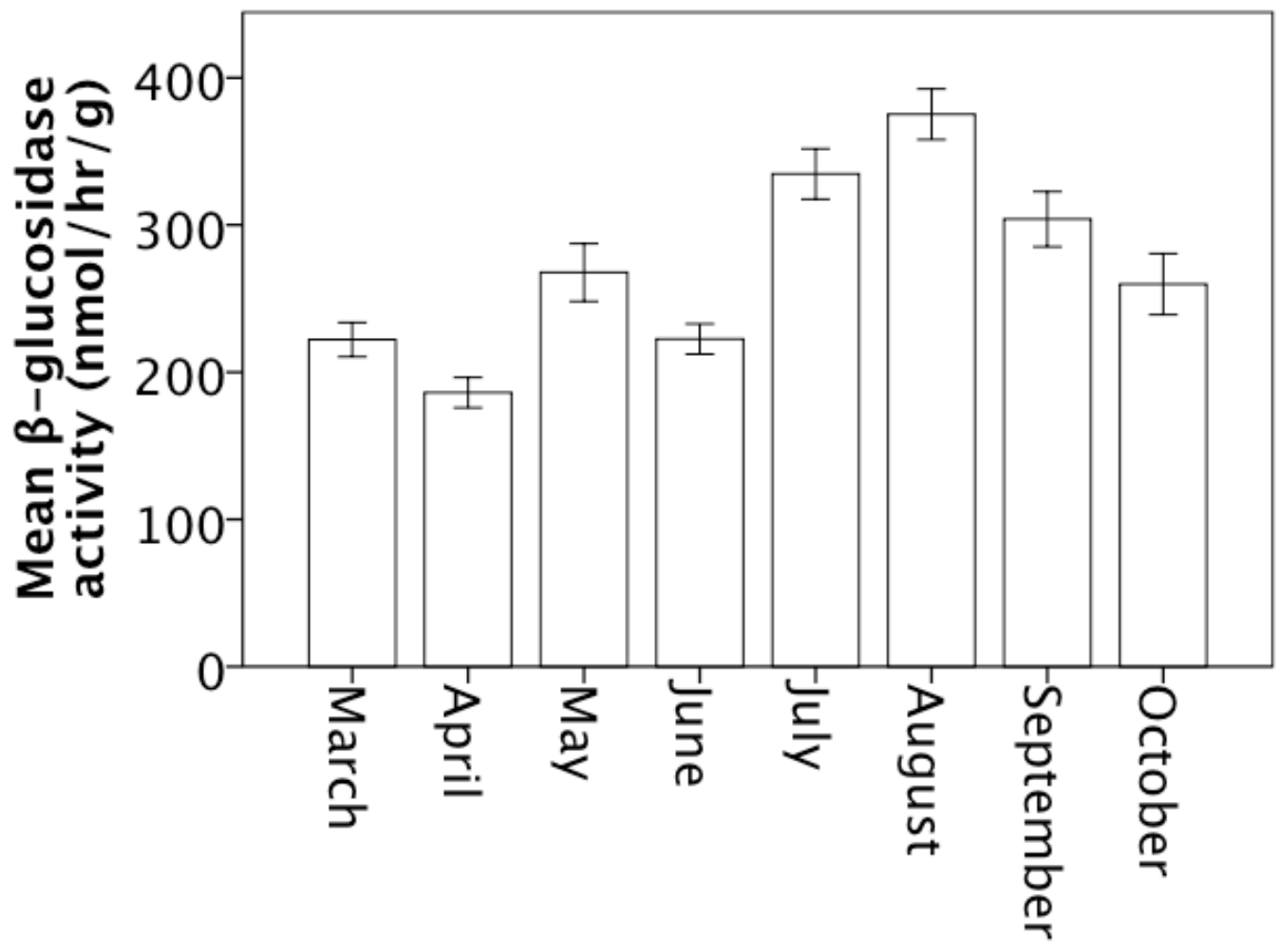

Month

Figure 5.7 Mean $\beta$-glucosidase activity at relevant treatment temperature varied significantly by month. Error bars are one standard error of the mean. 


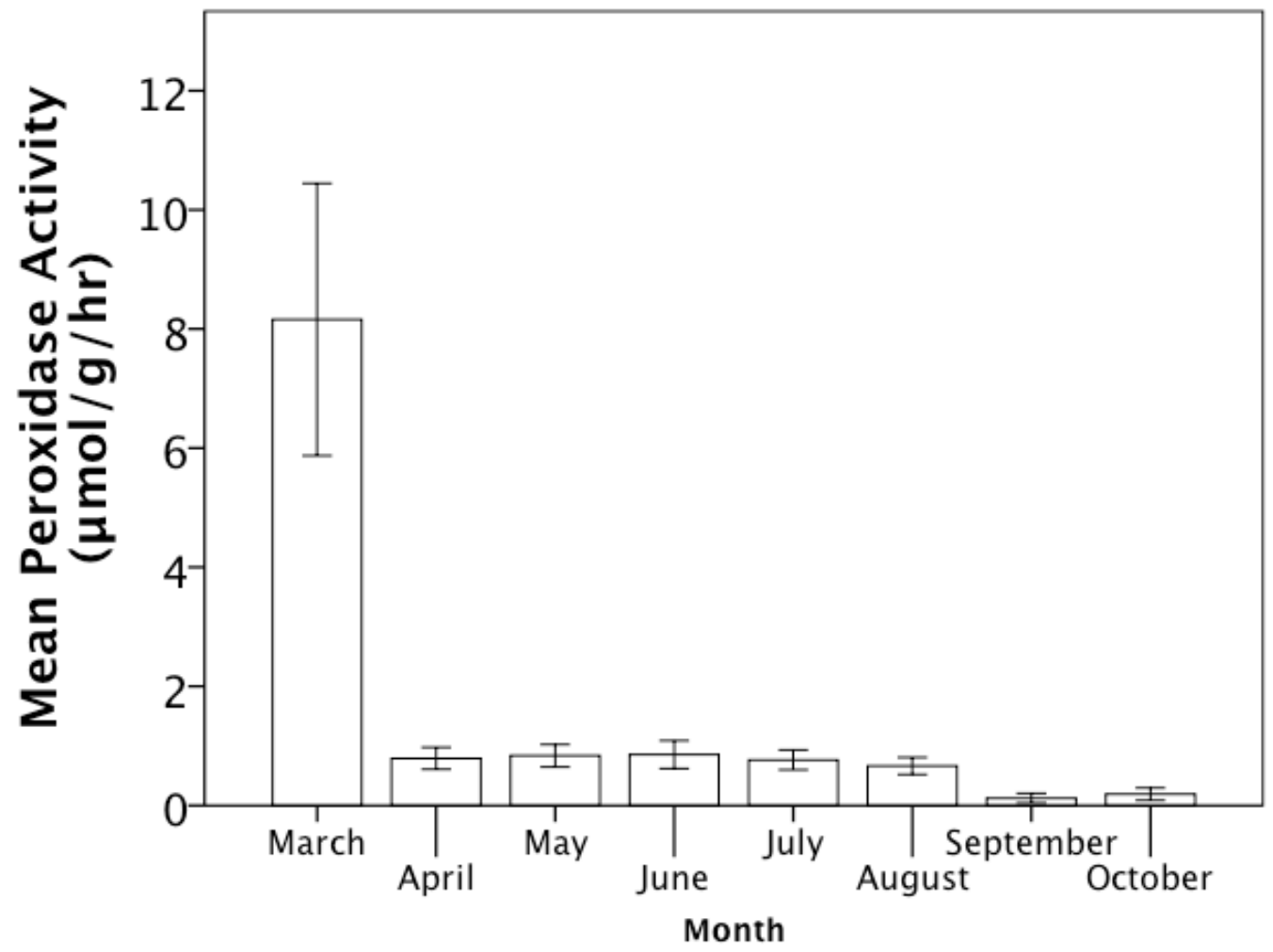

Error Bars: + /- $1 \mathrm{SE}$

Figure 5.8 Mean peroxidase activity at relevant treatment temperature varied significantly by month. Error bars are one standard error of the mean. 


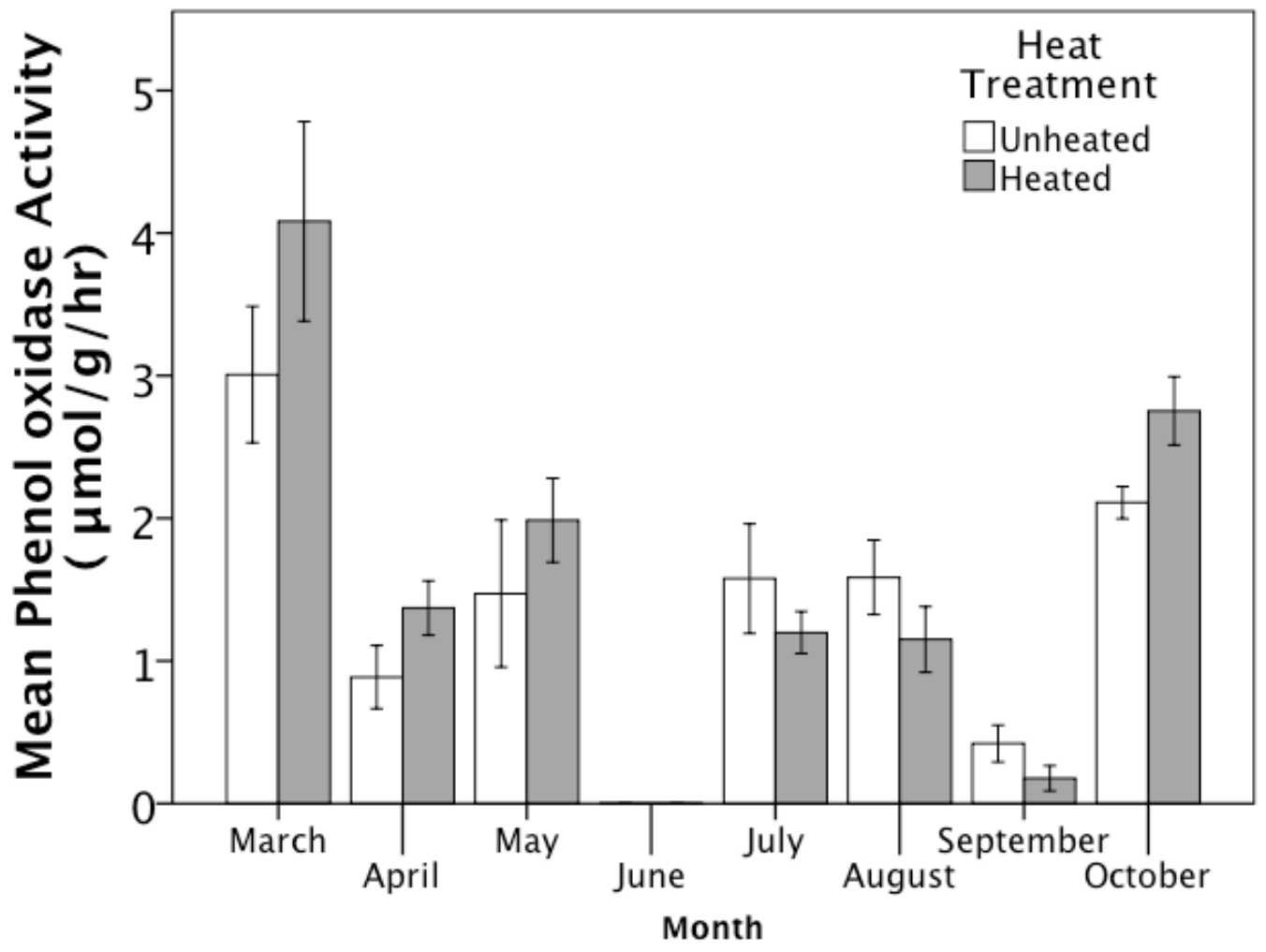

Figure 5.9 Mean phenol oxidase activity at $15^{\circ} \mathrm{C}$ showed a significant interaction between month and heat treatment, and also varied significantly by month. Error bars are one standard error of the mean. 


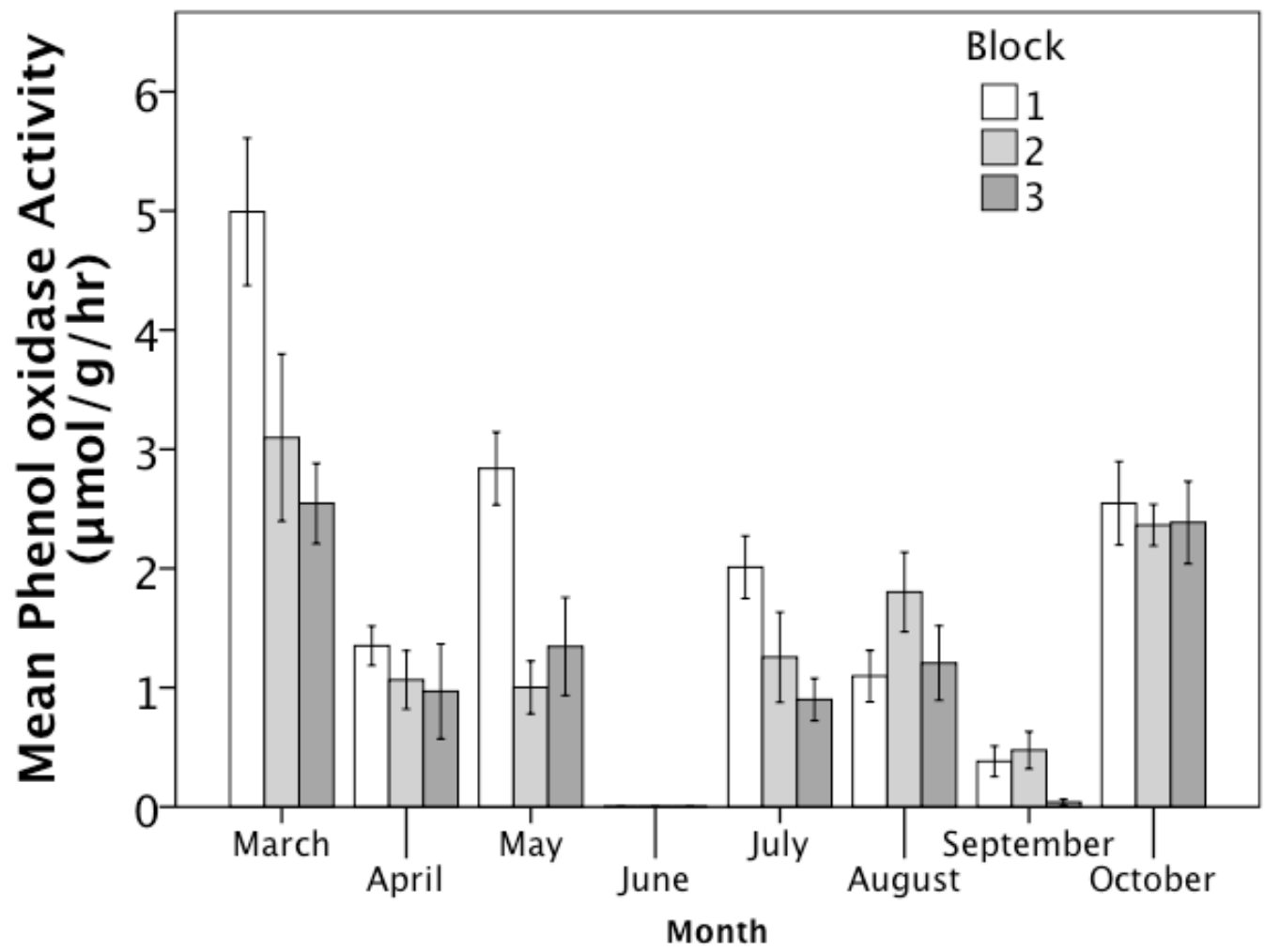

Figure 5.10 Mean phenol oxidase activity at $15^{\circ} \mathrm{C}$ varied significantly by block and month and also showed a significant interaction between month and block. Error bars are one standard error of the mean. 


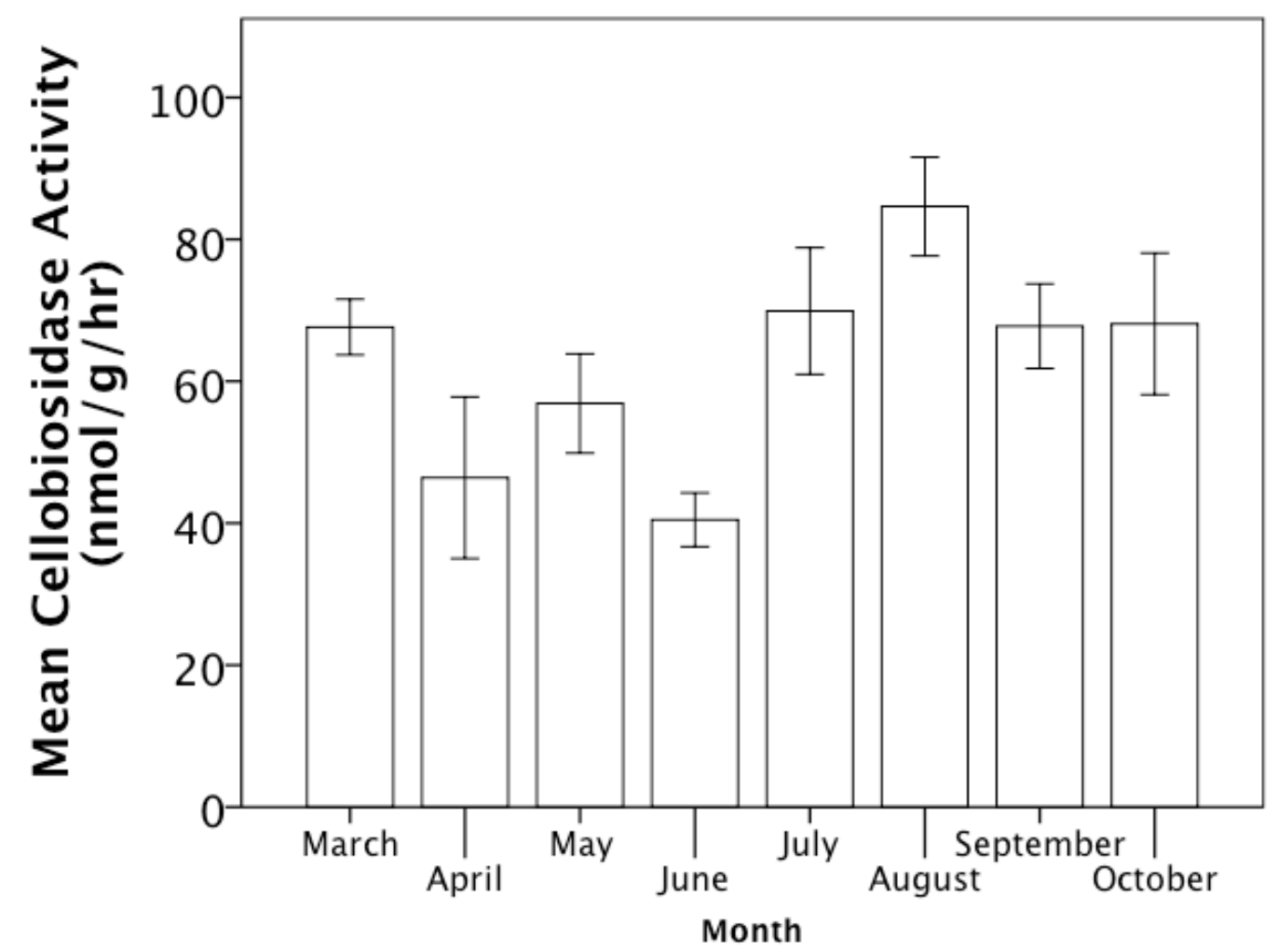

Figure 5.11 Mean cellobiosidase activity at $15^{\circ} \mathrm{C}$ varied significantly by month. Error bars are one standard error of the mean. 


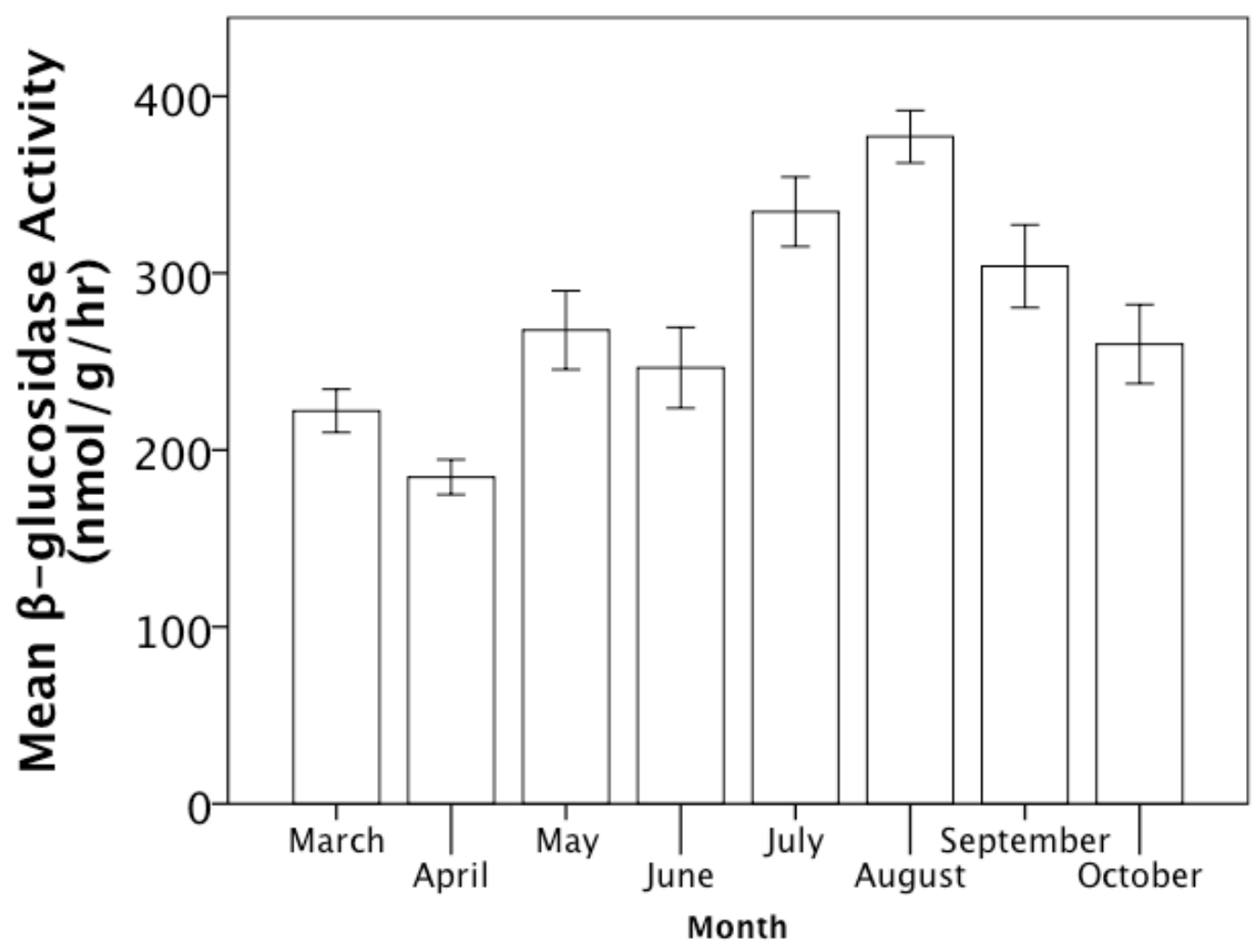

Figure 5.12 Mean $\beta$-glucosidase activity at $15^{\circ} \mathrm{C}$ varied significantly by month. Error bars are one standard error of the mean. 


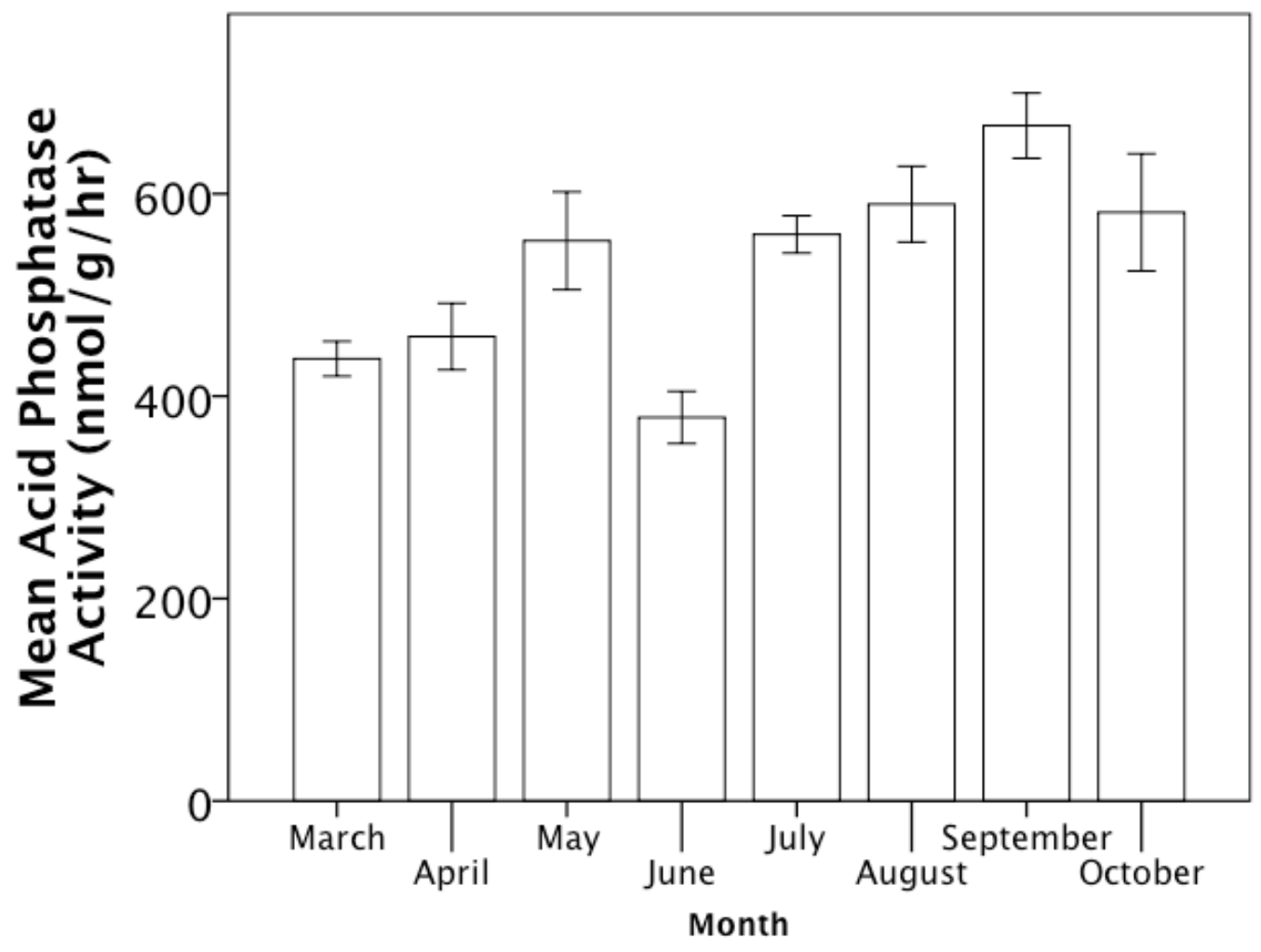

Figure 5.13 Mean acid phosphatase activity at $15^{\circ} \mathrm{C}$ varied significantly by month. Error bars are one standard error of the mean. 


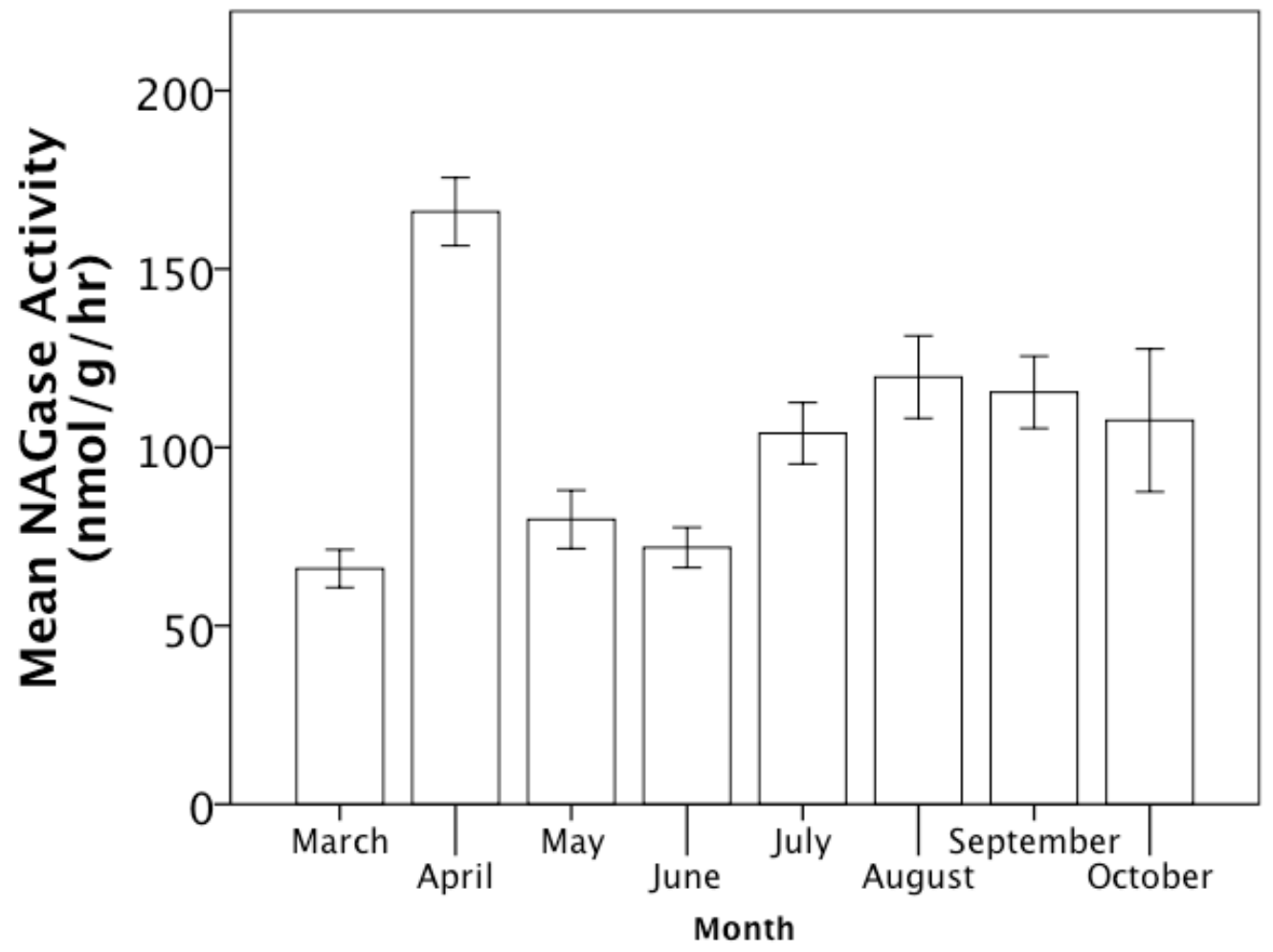

Figure 5.14 Mean NAGase activity at $15^{\circ} \mathrm{C}$ varied significantly by month. Error bars are one standard error of the mean. 


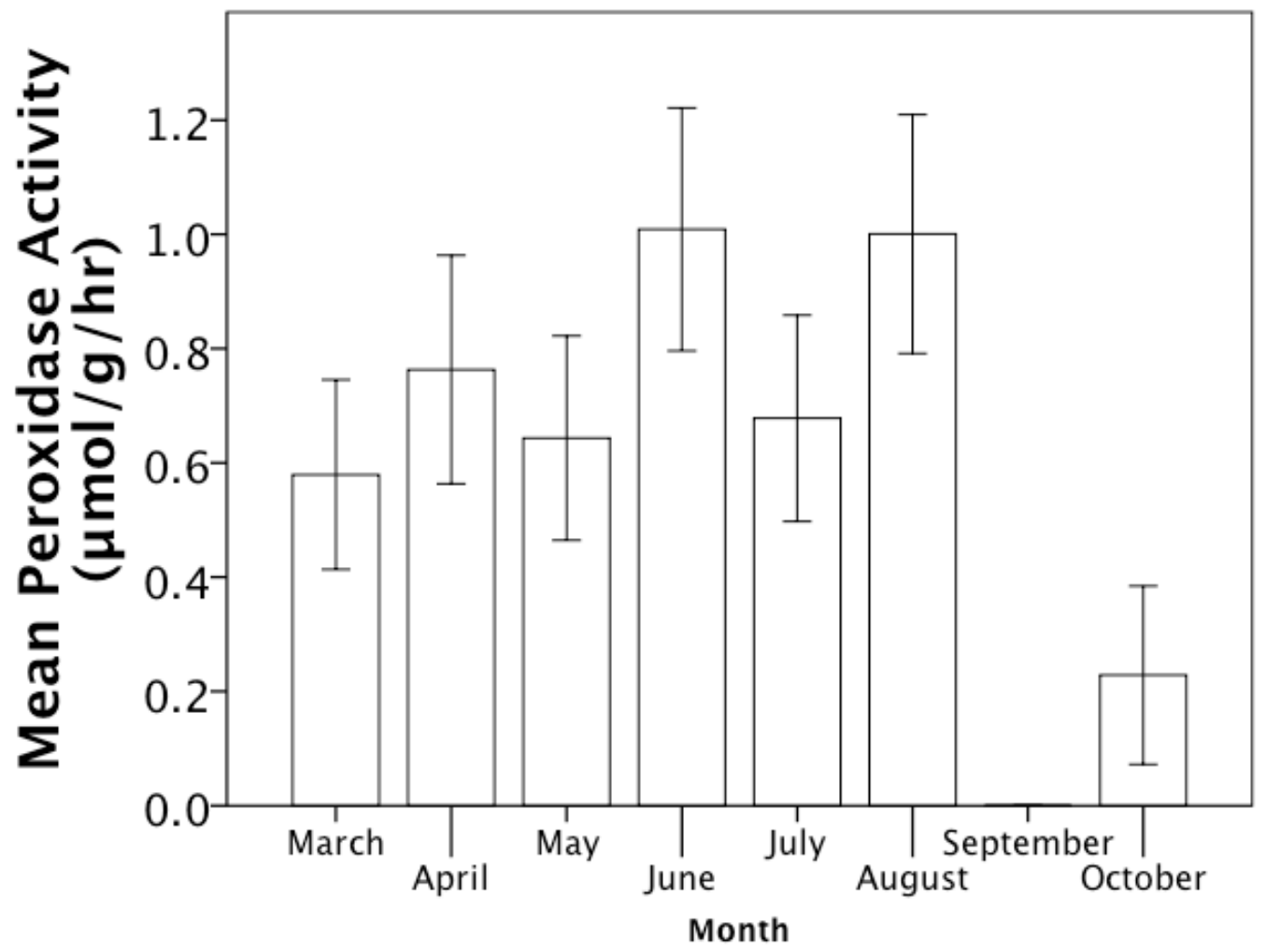

Figure 5.15 Mean peroxidase activity at $15^{\circ} \mathrm{C}$ varied significantly by month. Error bars are one standard error of the mean. 


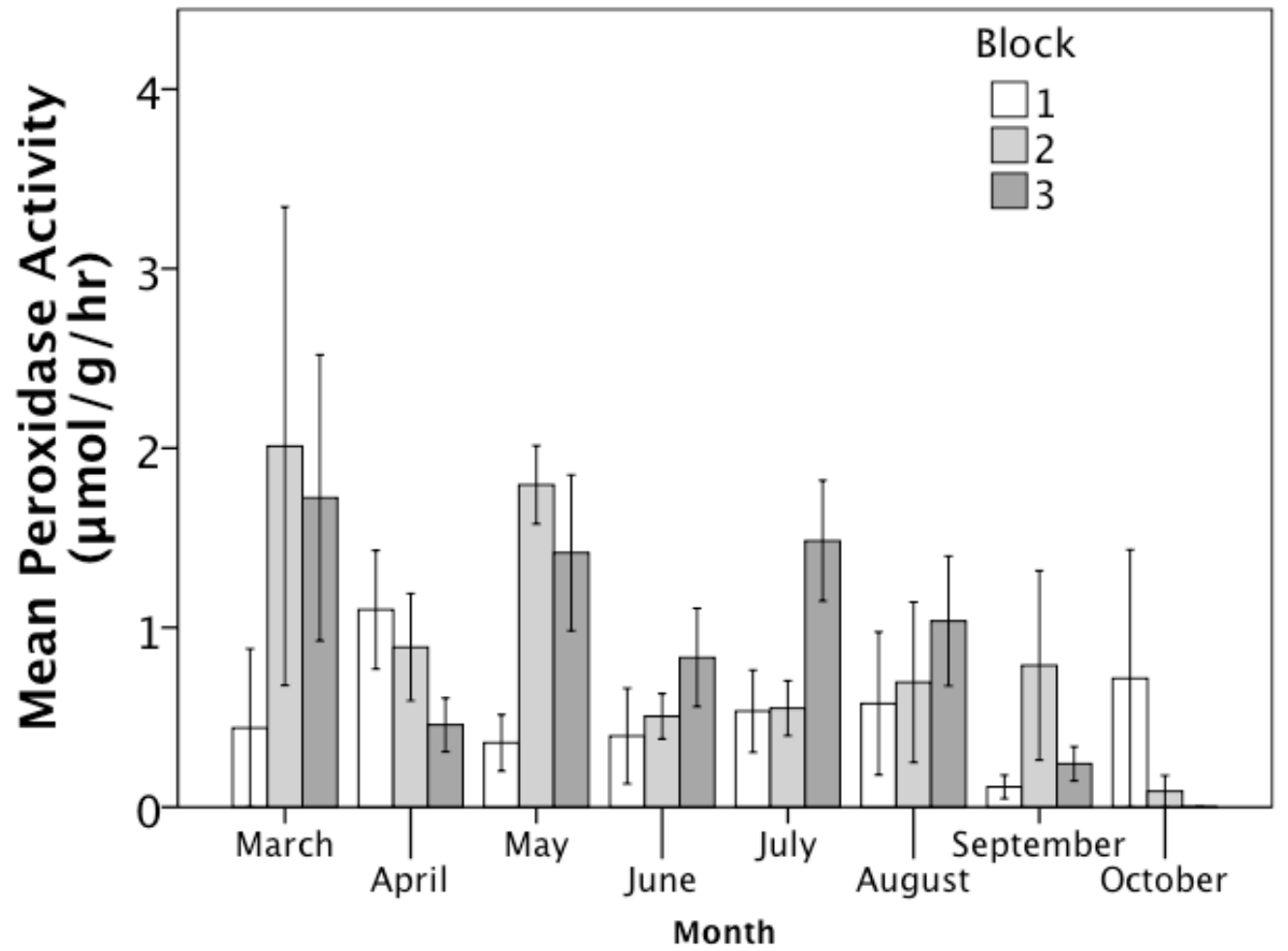

Figure 5.16 Mean peroxidase activity at $20^{\circ} \mathrm{C}$ varied significantly by month and block. There was also a significant month by block interaction. Error bars are one standard error of the mean. 


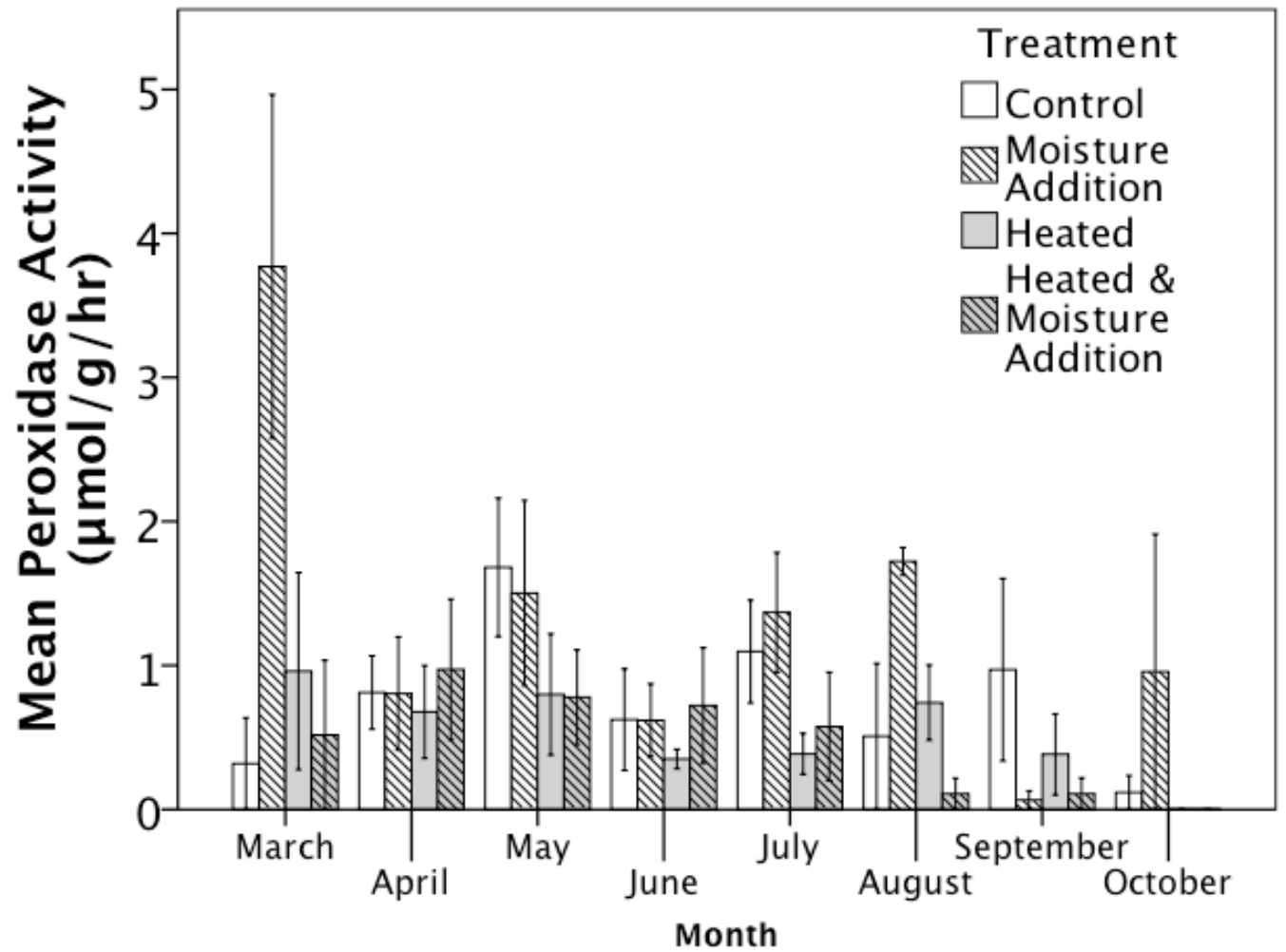

Figure 5.17 Mean peroxidase activity at $20^{\circ} \mathrm{C}$ varied significantly by month. There was also a significant month by heat interaction. There was a significant effect of heat treatment, water treatment, and month with significant interactions between month and block and heat and water. There was also a significant three-way interaction between month, heat and water. Error bars are one standard error of the mean. 


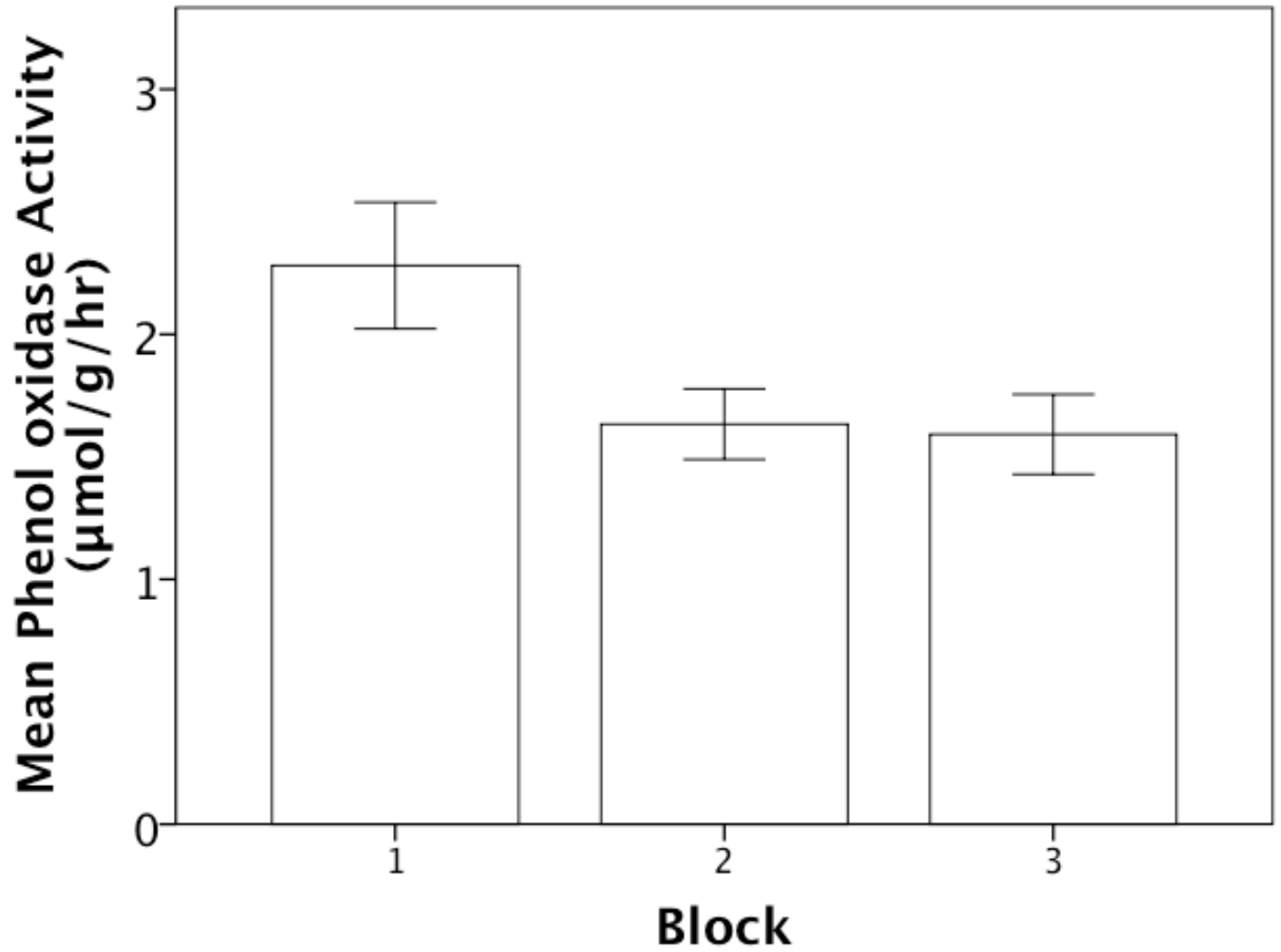

Figure 5.18 Block 1 had significantly greater phenol oxidase activity at $20^{\circ} \mathrm{C}$ versus other blocks. Error bars are one standard error of the mean. 


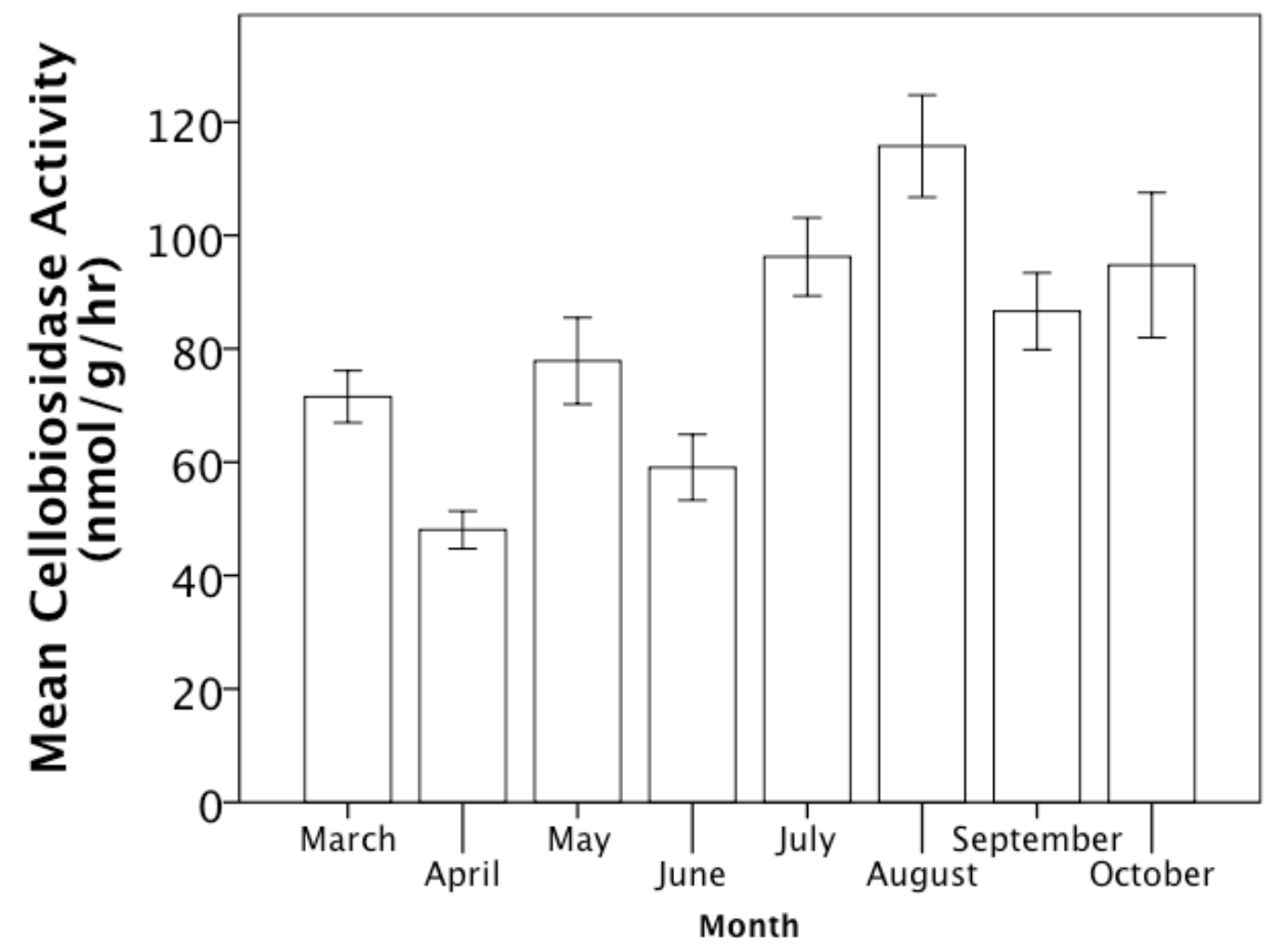

Figure 5.19 Mean cellobiosidase activity at $20^{\circ} \mathrm{C}$ varied significantly by month. Error bars are one standard error of the mean. 


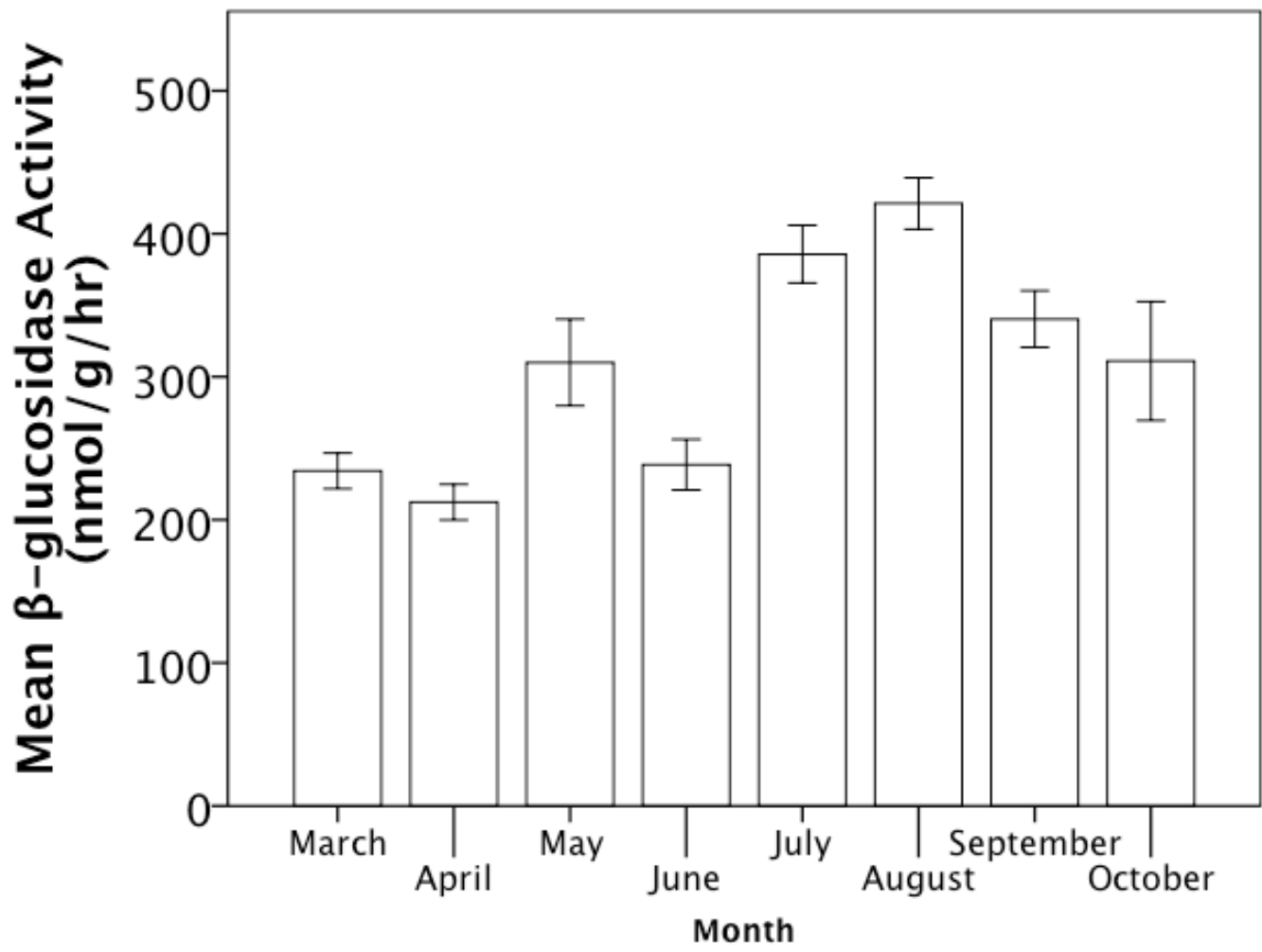

Figure 5.20 Mean $\beta$-glucosidase activity at $20^{\circ} \mathrm{C}$ varied significantly by month. Error bars are one standard error of the mean. 


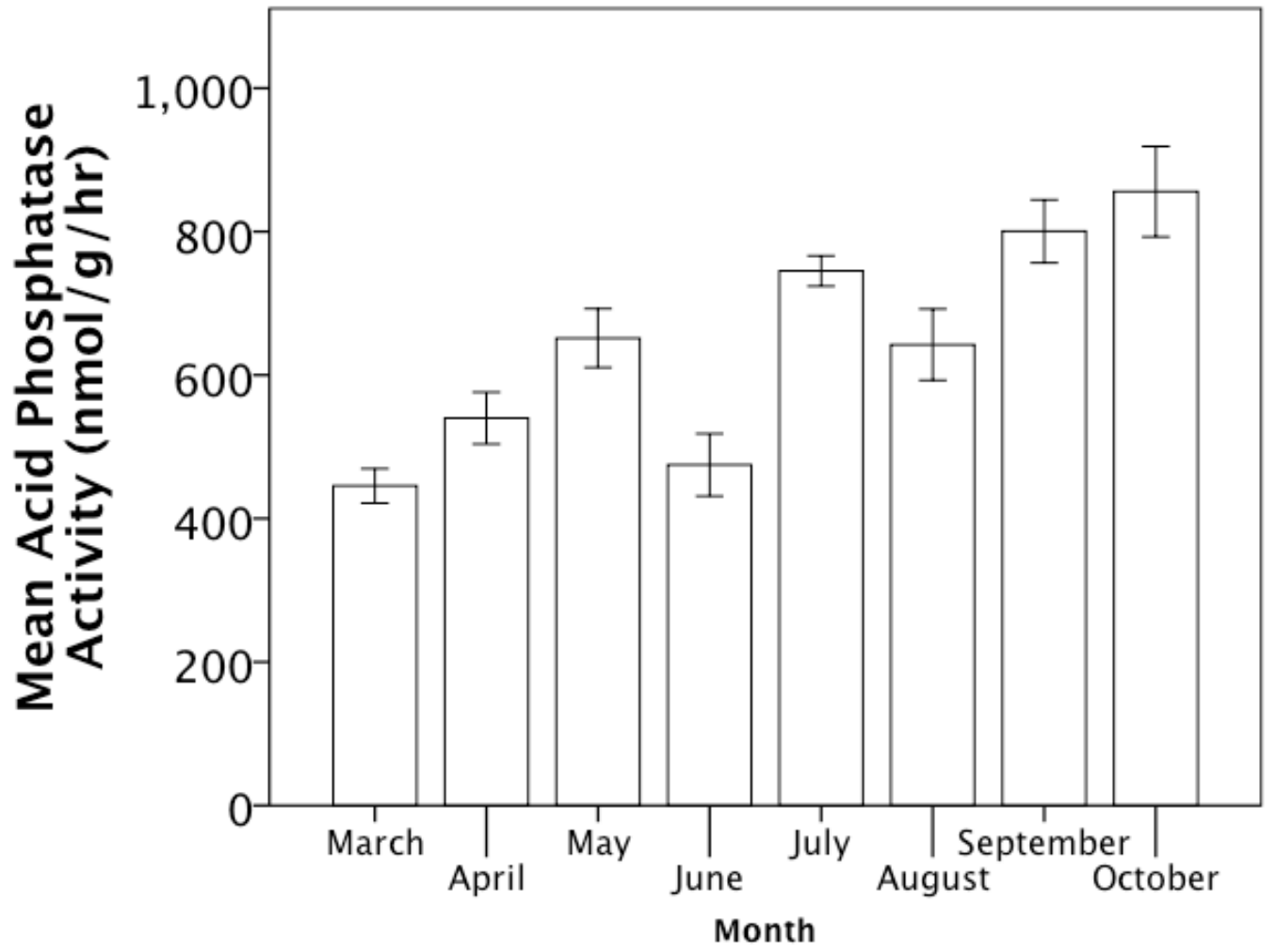

Figure 5.21 Mean acid phosphatase activity at $20^{\circ} \mathrm{C}$ varied significantly by month. Error bars are one standard error of the mean. 


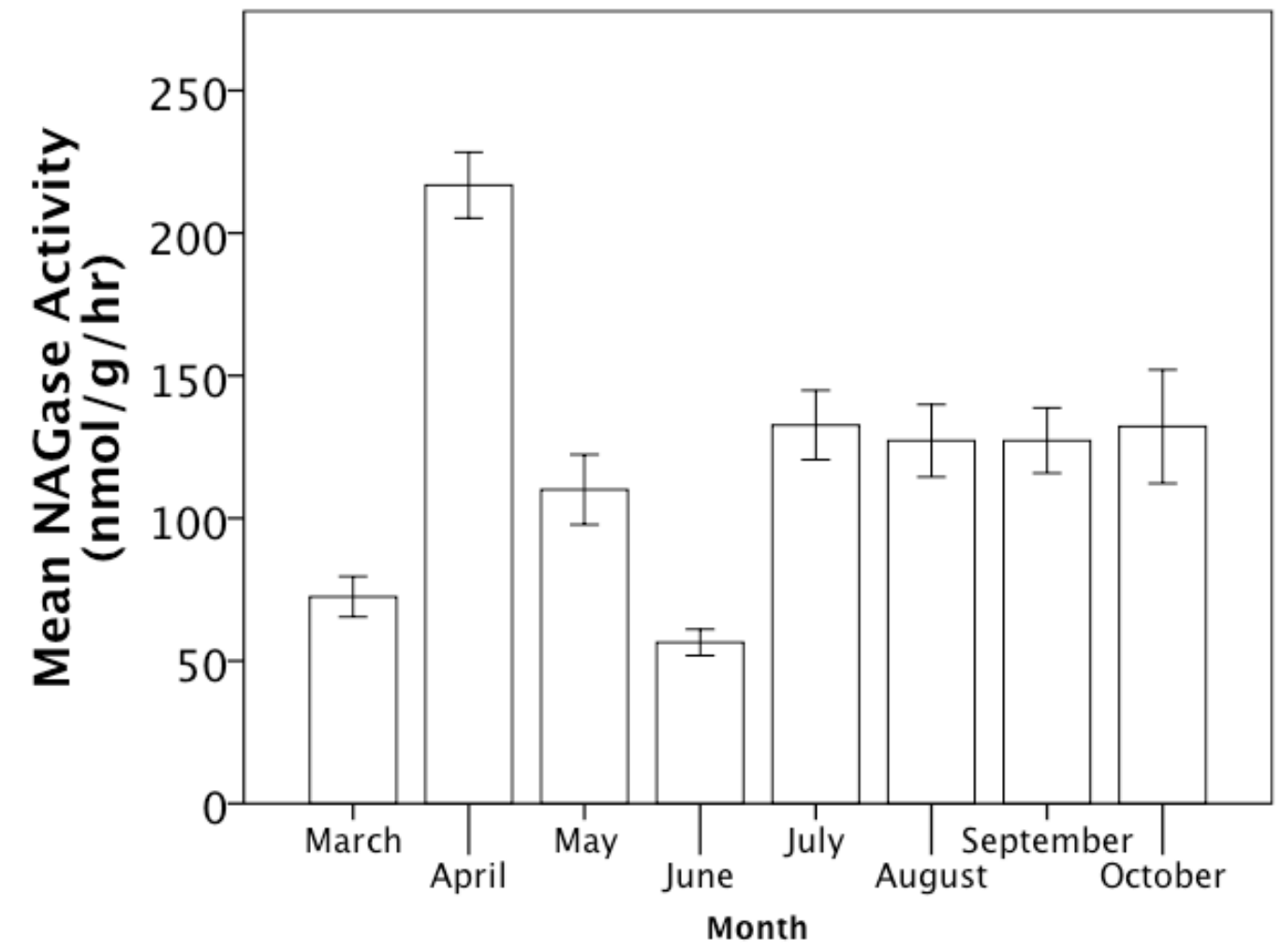

Figure 5.22 Mean NAGase activity at $20^{\circ} \mathrm{C}$ varied significantly by month. Error bars are one standard error of the mean. 


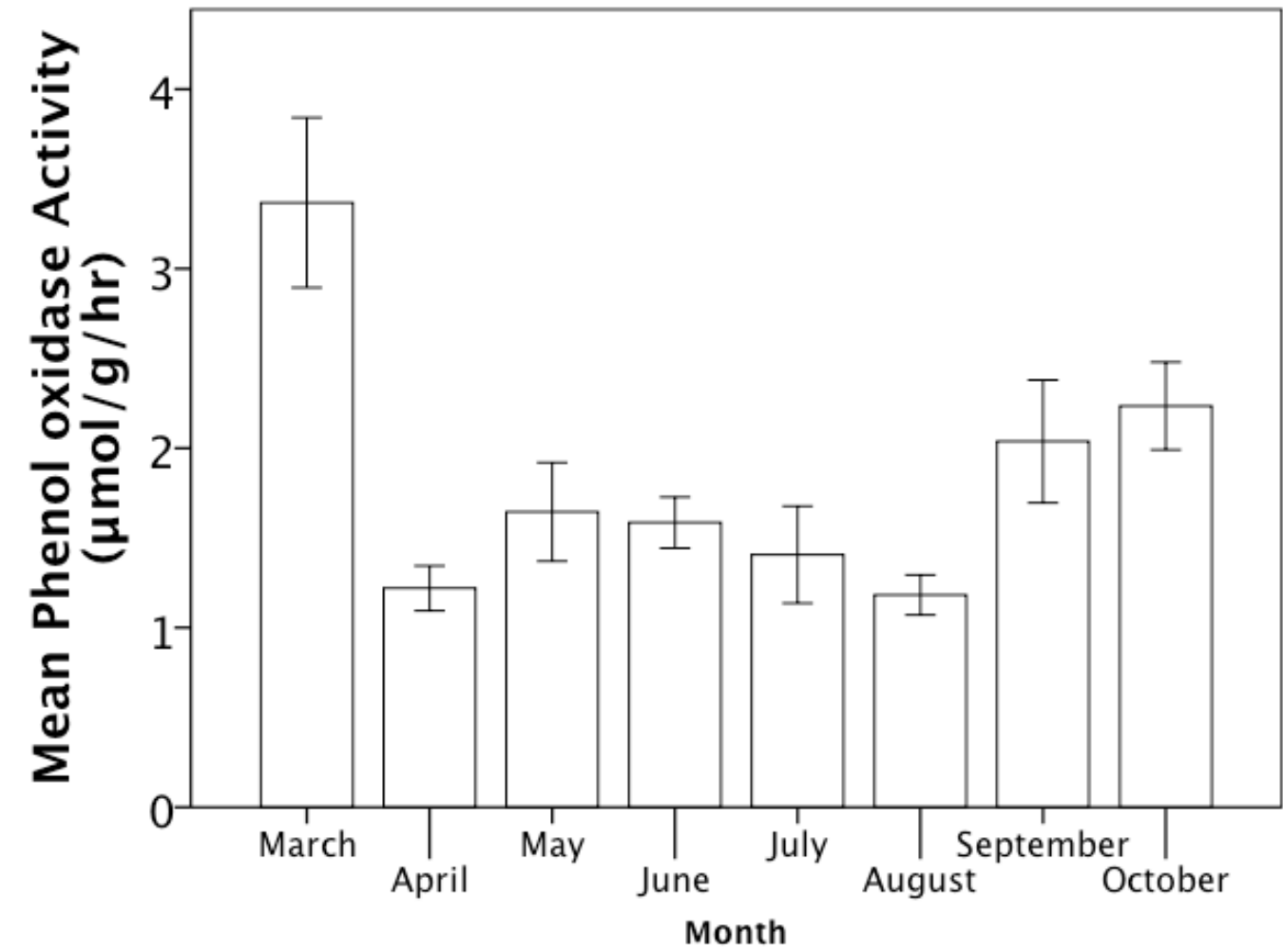

Figure 5.23 Mean phenol oxidase activity at $20^{\circ} \mathrm{C}$ varied significantly by month. Error bars are one standard error of the mean. 


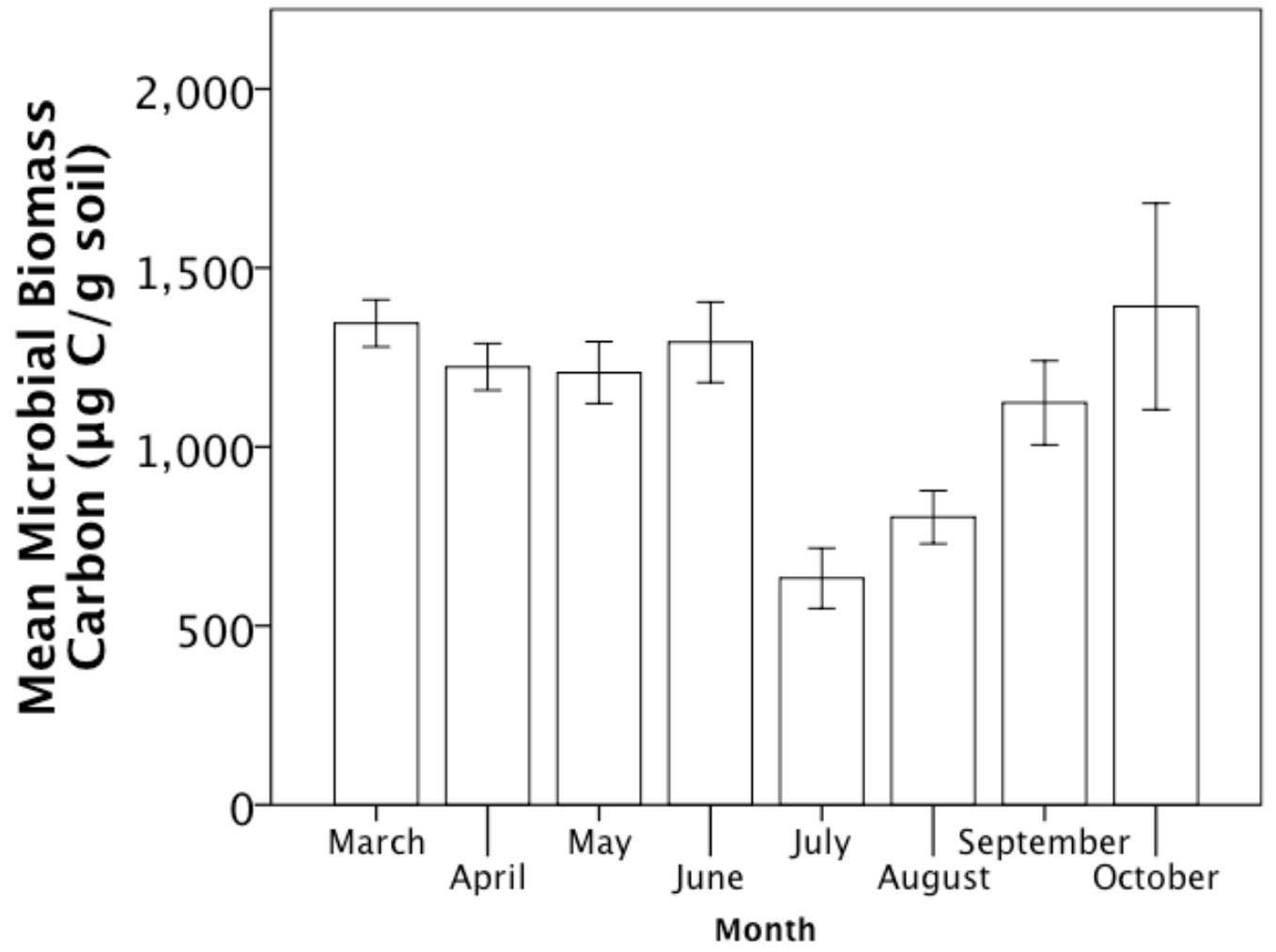

Figure 5.24 Mean microbial biomass $\mathrm{C}$ varied significantly by month. Error bars are one standard error of the mean. 


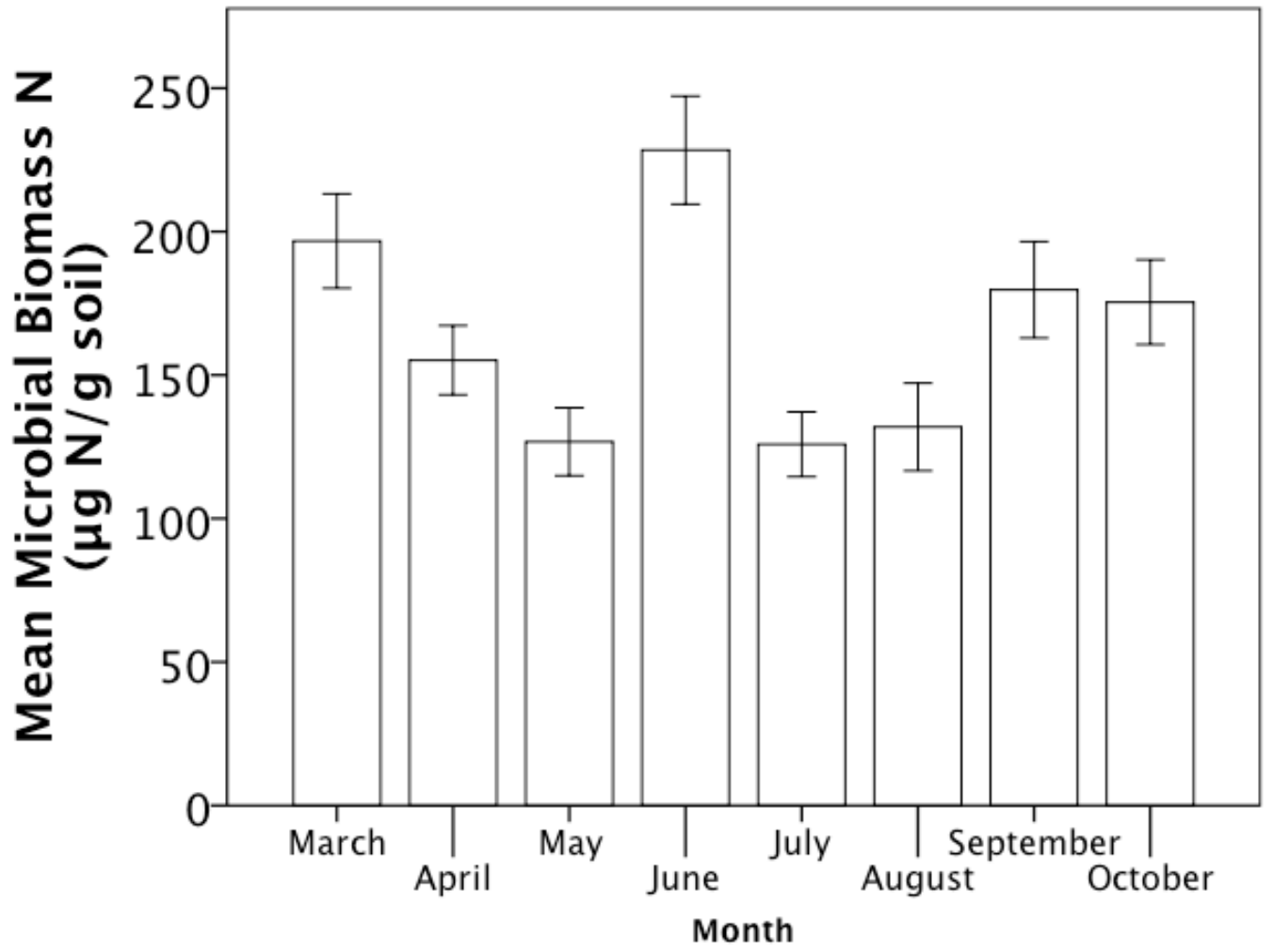

Figure 5.25 Mean microbial biomass $\mathrm{N}$ varied significantly by month. Error bars are one standard error of the mean. 


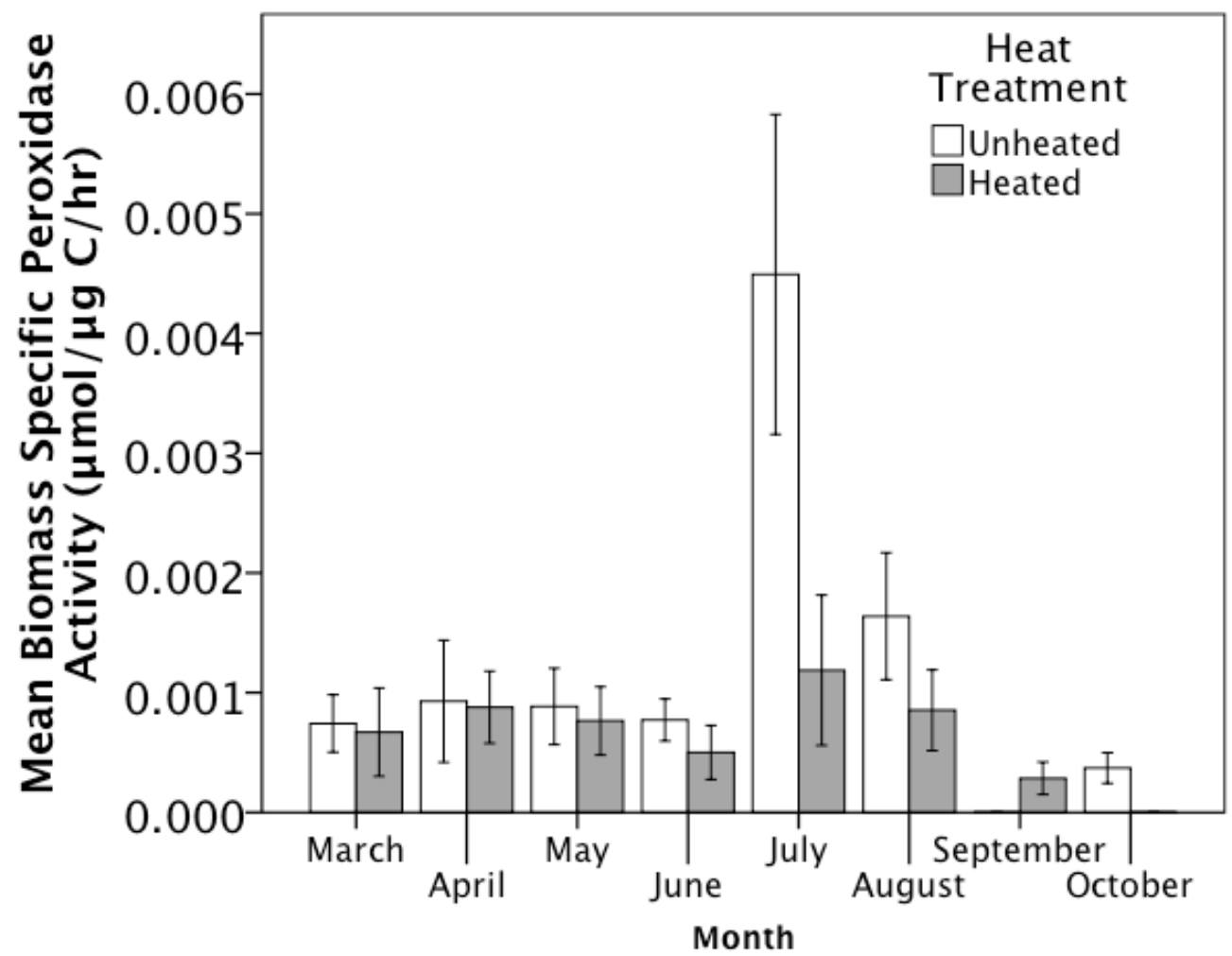

Figure 5.26 Mean biomass-specific peroxidase activity at relevant treatment temperature showed a significant month by heat interaction and also varied significantly by month. Error bars are one standard error of the mean. 


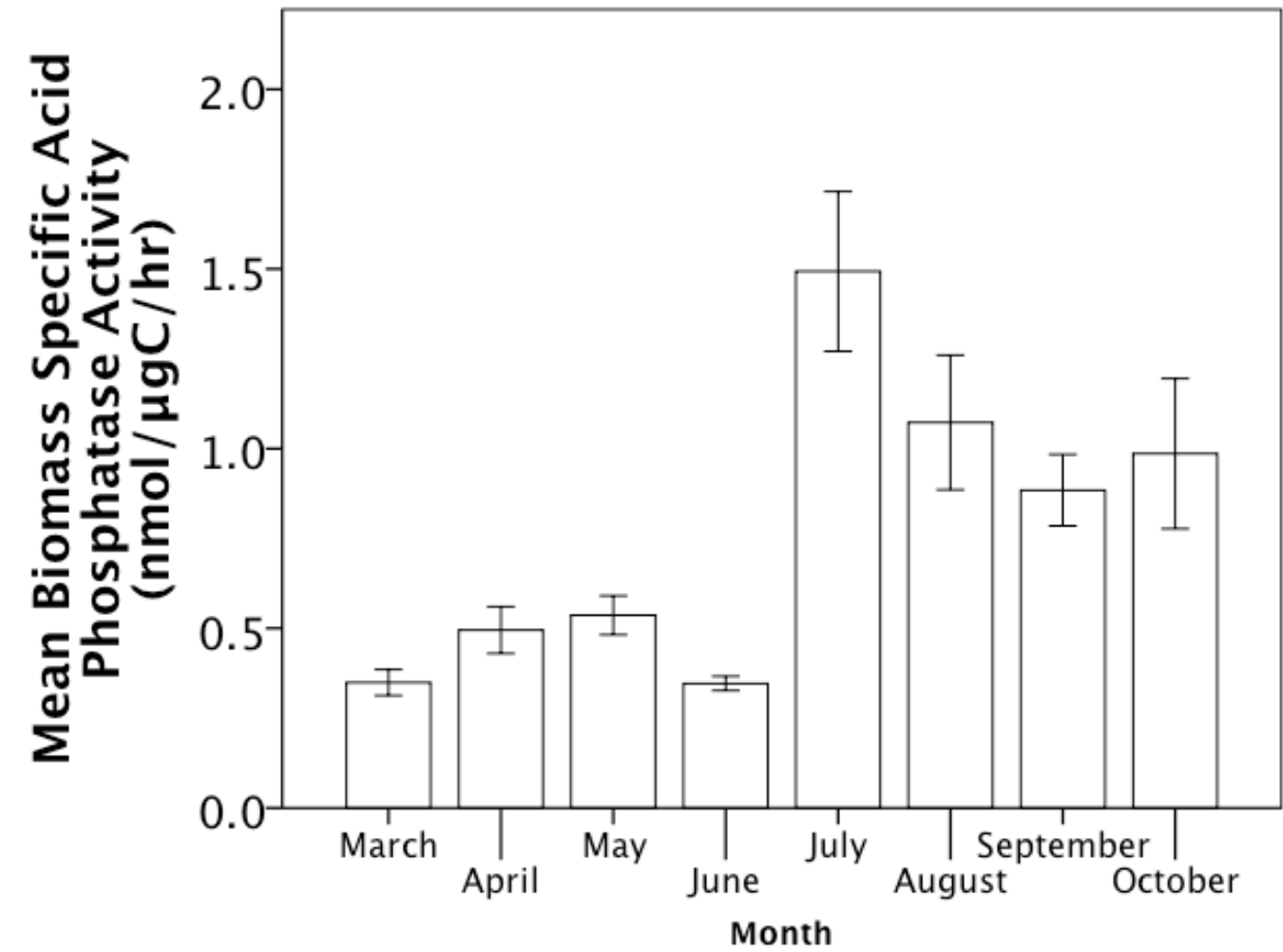

Figure 5.27 Mean biomass-specific acid phosphatase activity at relevant treatment temperature varied significantly by month. Error bars are one standard error of the mean. 


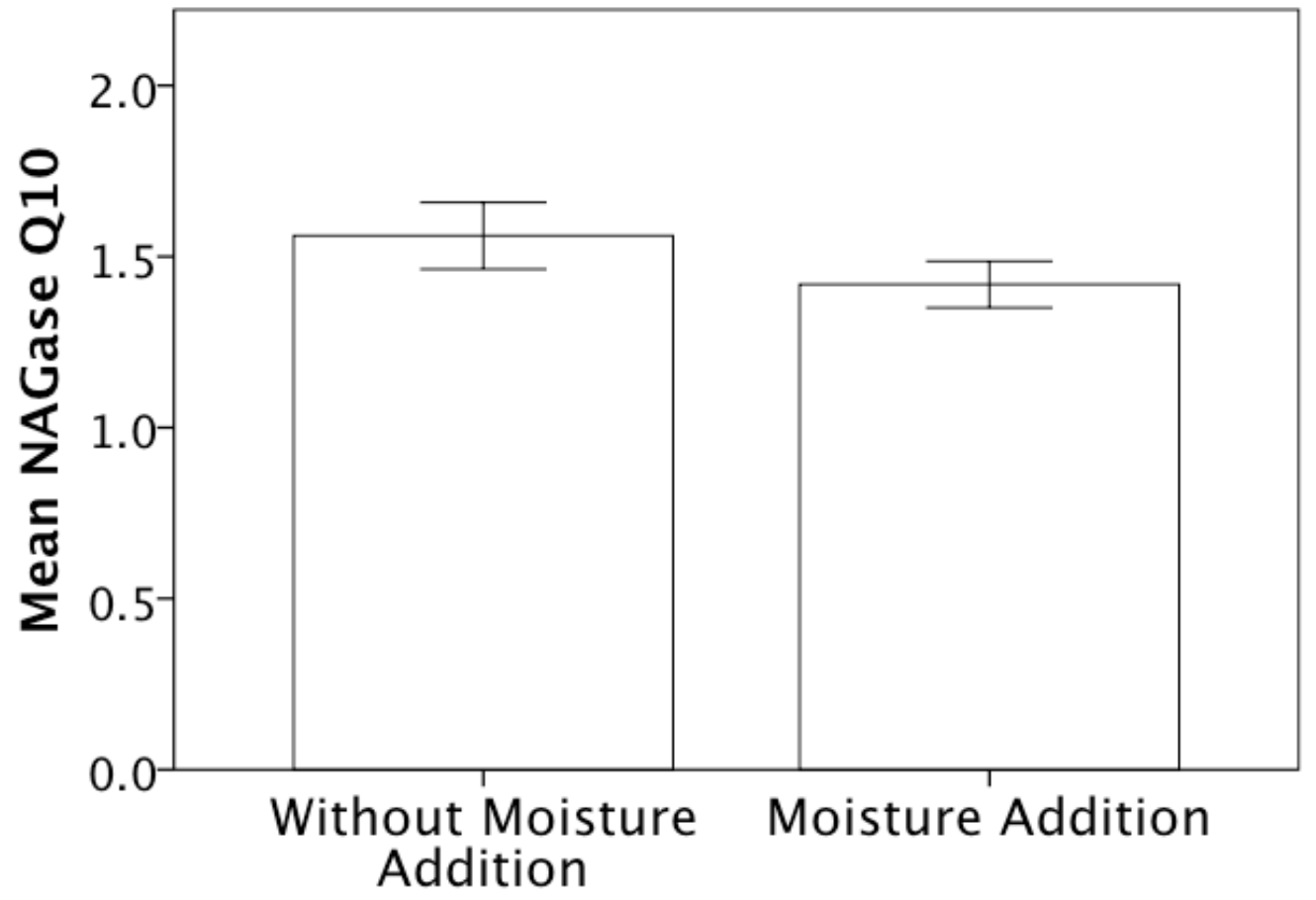

Figure 5.28 Mean NAGase $\mathrm{Q}_{10}$ was lower in plots with moisture addition versus plots lacking moisture addition, although significance was only marginal $(P=0.052)$. Error bars are one standard error of the mean. 


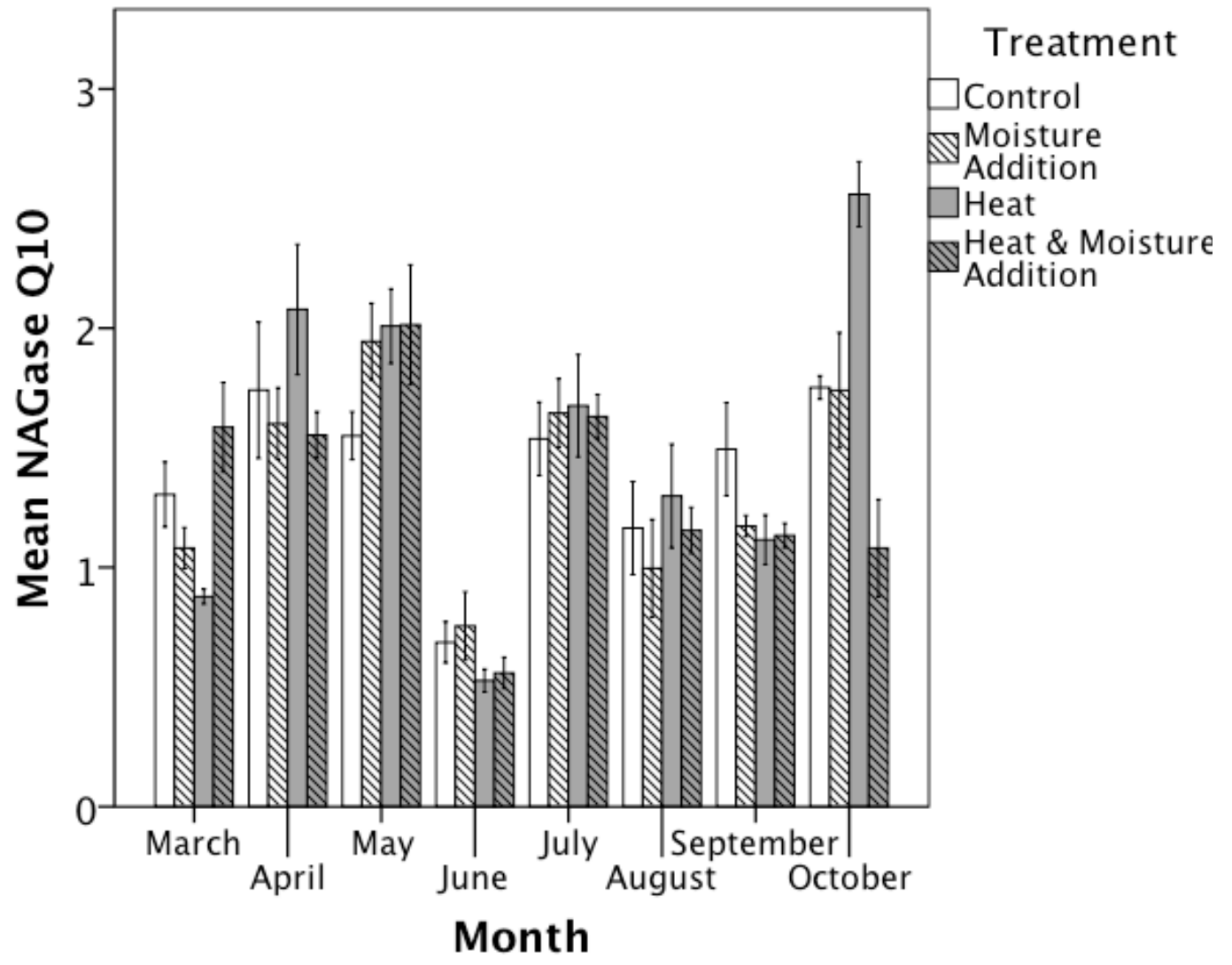

Figure 5.29 Mean NAGase $\mathrm{Q}_{10}$ differed significantly by month and also showed a significant interaction between month and water. The three-way interaction between month, heat and moisture was also significant. Error bars are one standard error of the mean. 


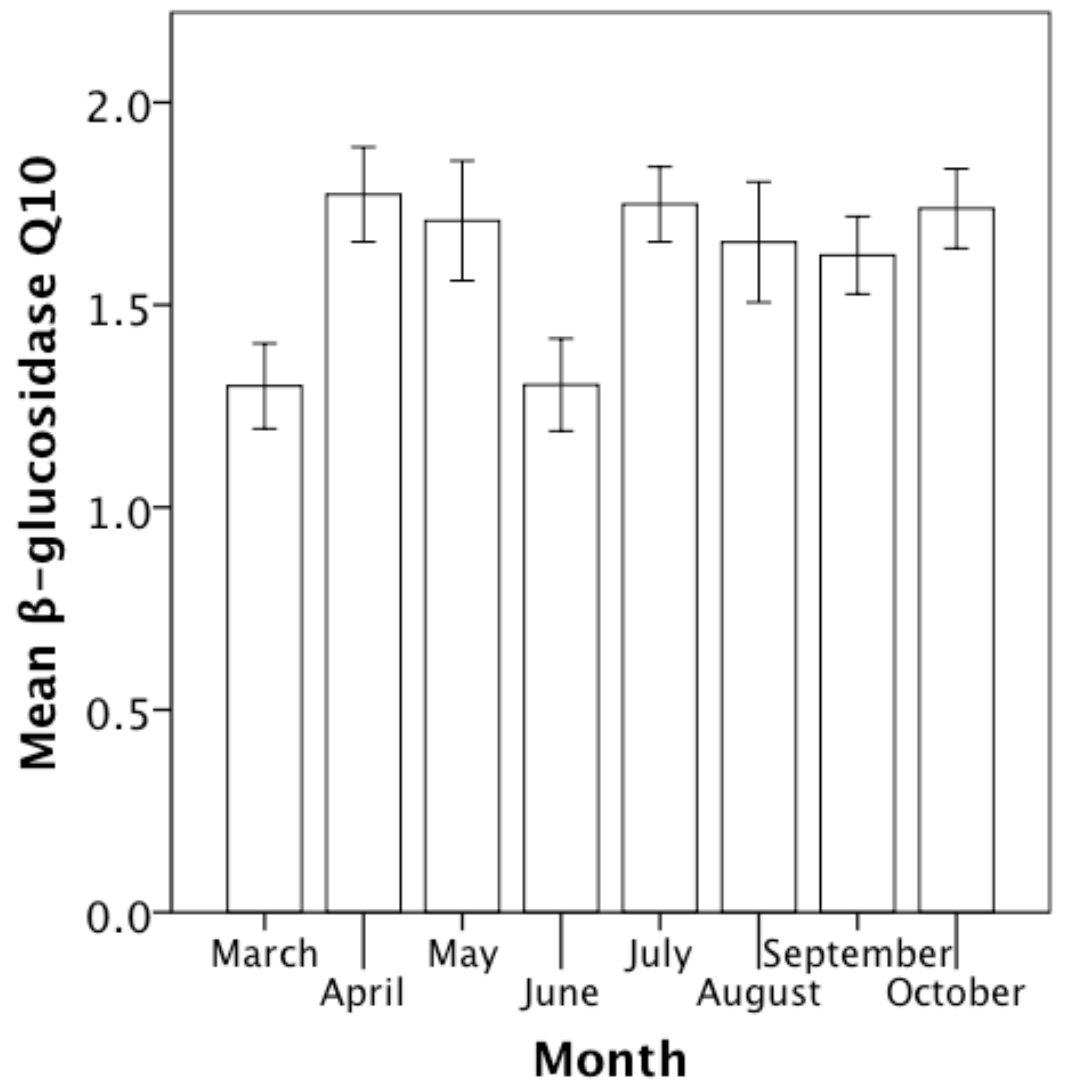

Figure 5.30 Mean $\beta$-glucosidase $\mathrm{Q}_{10}$ differed significantly by month. $\beta$-glucosidase $\mathrm{Q}_{10}$ was lower in March and June compared to other months. Error bars are one standard error of the mean. 


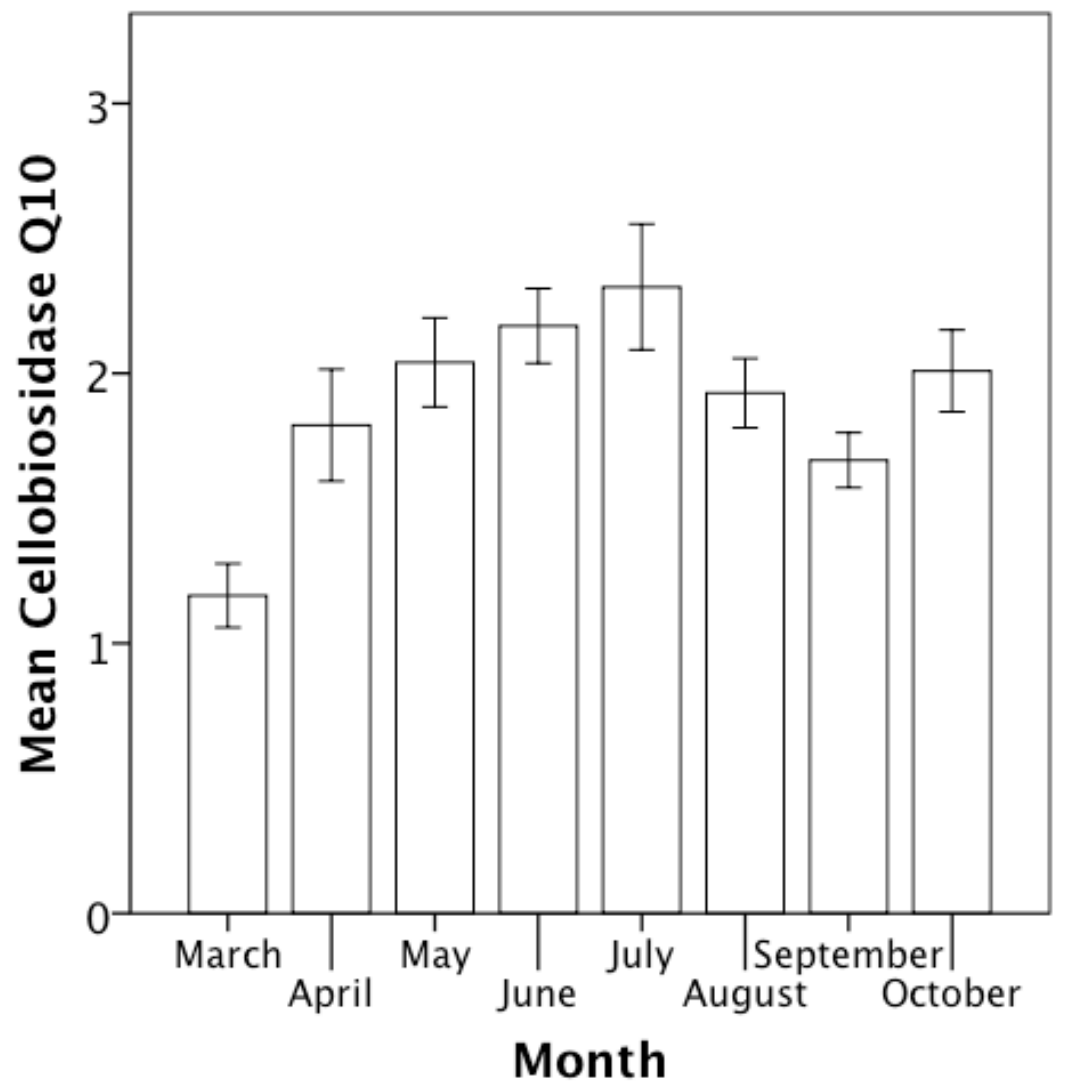

Figure 5.31 Mean cellobiosidase $\mathrm{Q}_{10}$ differed significantly by month, increasing from March to July, and decreasing again from August to October. Error bars are one standard error of the mean. 


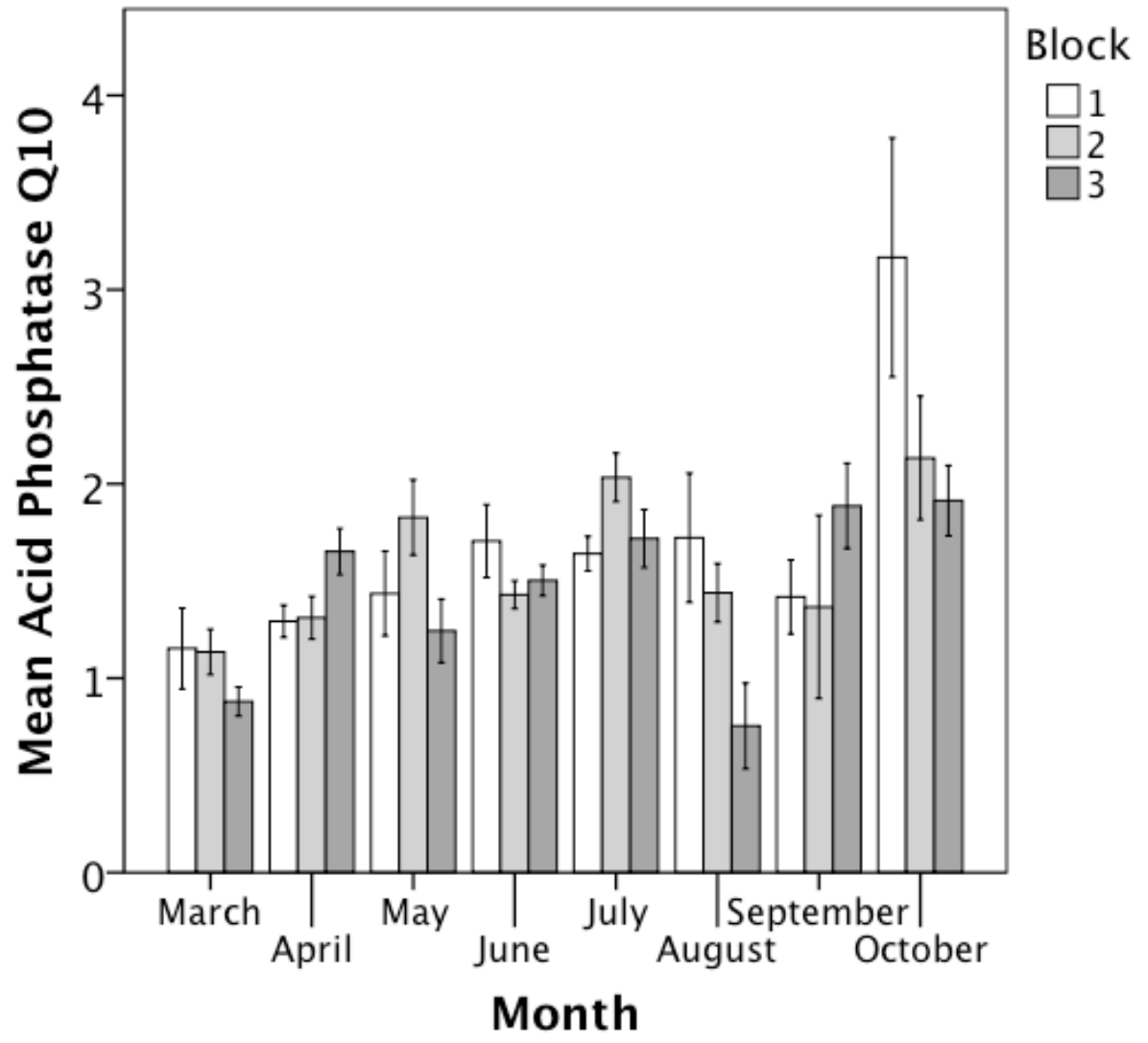

Figure 5.32 Mean acid phosphatase activity differed significantly by month and showed a significant month by block interaction. Error bars are one standard error of the mean. 


\subsection{References}

Allison, S.D. 2005. Cheaters, diffusion and nutrients constrain decomposition by microbial enzymes in spatially structured environments. Ecology Letters. 8: 626-635.

Allison, S.D., McGuire, K.M., and K.K. Treseder. 2010. Resistance of microbial and soil properties to warming treatment seven years after boreal fire. Soil Biology and Biochemistry. 42: 1872-1878.

Allison, S.D. and K.K. Treseder. 2008. Warming and drying suppress microbial activity and carbon cycling in boreal forest soils. Global Change Biology. 14: 2898-2909.

Arnold, S.S., Fernandez, I.J., Rustad, L.E. and L.M. Zibilske. 1999. Microbial response of an acid forest soil to experimental soil warming. Biology and Fertility of Soils. 30: 239-244.

Barnes, B.V., Zak, D.R., Denton, S.R. and S.H. Spurr. 1998. Chapter 11: Soil. In Forest Ecology $4^{\text {th }}$ Edition. John Wiley \& Sons, Inc. New York, NY, USA.

Bell, T.H., Klironomos, J.N. and H.A.L. Henry. 2010. Seasonal responses of extracellular enzyme activity and microbial biomass to warming and nitrogen addition. Soil Science Society of America Journal. 74: 820-828.

Bond-Lamberty, B. and A. Thomson. 2010. Temperature-associated increases in the globabl soil respiration record. Science. 464: 579-582.

Bradford, M.A., Davies, C.A., Frey, S.D., Maddox, T.R., Melillo, J.M., Mohan, J.E., Reynolds, J.F. and K.K. Treseder. 2008. Thermal adaptation of soil microbial respiration to elevated temperatures. Ecology Letters. 11: 1316-1327.

Burton, A.J., Jarvey, J.C., Jarvi, M.P., Zak, D.R., and K.S. Pregitzer. 2012. Chronic $\mathrm{N}$ alters root respiration-tissue $\mathrm{N}$ relationship in northern hardwood forests. Global Change Biology. 18: 258-266.

Christensen, J. H., Hewitson, B., Busuioc, A. et al. In: Climate Change 2007: The Physical Science Basis. Contribution of Working Group I to the Fourth Assessment Report of the Intergovernmental Panel on Climate Change. Solomon, S. et al. (eds.). Cambridge University Press: New York, New York, USA 
Feller, G. and C. Gerday. 2003. Psychrophilic enzymes: Hot topics in cold adaptation. Nature Reviews. 1: 200-208.

Fenner, N., Freeman, C. and B. Reynolds. 2005. Observations of a seasonally shifting thermal optimum in peatland carbon-cycling processes: Implications for the global carbon cycle and soil enzyme methodologies. Soil Biology and Biochemistry. 37: 1814-1821.

Frey, S.D., Drijber, R., Smith, H. and J. Melillo. 2008. Microbial biomass, functional capacity, and community structure after 12 years of soil warming. Soil Biology and Biochemistry. 40: 2904-2907.

German, D.P., Weintraub, M.N., Grandy, A.S., Lauber, C.L., Rinkes, Z.L. and S.D. Allison. 2011. Optimization of hydrolytic and oxidative enzyme methods for ecosystem studies. Soil Biology \& Biochemistry. 43(7): 1387-1397.

Horwath, W.R. and E.A. Paul. 1994. Chapter 36: Microbial Biomass. In Methods of Soil Analysis: Part 2-Microbiological and Biochemical Properties. Eds. Weaver, R.W., Angle, J.S. and P.S. Bottomley. Soil Science Society of America Inc., Madison, WI, USA.

Koch, O., Tscherko, D., E. Kandeler. 2007. Temperature sensitivity of microbial respiration, nitrogen mineralization, and potential soil enzyme activities in organic alpine soils. Global Biogeochemical Cycles. 21: GB4017, doi:10.1029/2007GB002983.

Luo et al. 2001 Luo, Y., Wan, S., Hui, D., Wallace, L.L., 2001. Acclimatization of soil respiration to warming in a tall grass prairie. Nature. 413: 622-624.

Meehl, G. A. et al. In: Climate Change 2007: The Physical Science Basis. Contribution of Working Group I to the Fourth Assessment Report of the Intergovernmental Panel on Climate Change. Solomon, S. et al. (eds.). Cambridge University Press: New York, New York, USA.

Melillo, J.M., Steudler, P.A., Aber, J.D., Newkirk, K., Lux, H., Bowles, F.P., Catricala, C., Magill, A., Ahrens, T. and S. Morrisseau. 2002. Soil warming and carbon-cycle feebacks to the climate system. Science. 298: 2173-2165. 
Oechel, W.C., Vourlitis, G.L., Hastings, S.J., Zulueta, R.C., Hinzman, L., Kane, D., 2000.Acclimation of ecosystem CO2 exchange in the Alaskan Artic in response to decadal climate warming. Nature. 406: 978-981.

Raich, J. W. and C. S. Potter. 1995. Global patterns of carbon dioxide emissions from soils. Global Biogeochemical Cycles. 9: 23-36.

Schindlbacher, A., Rodler, A., Kuffner, M., Kitzler, B., Sessitsch, A. and S. Zechmeister-Boltenstern. 2011. Experimental warming effects on the microbial community of a temperate mountain forest soil. Soil Biology \& Biochemistry. 43: 1417-1425.

Sinsabaugh, R.L., Gallo, M.E., Lauber, C., Waldrop, M.P. and D.R. Zak. 2005. Extracellular enzyme activities and soil organic matter dynamics for northern hardwood forests receiving simulated nitrogen deposition. Biogeochemistry. 75(2): 201-215.

Waldrop, M.P. and M.K. Firestone. 2004. Altered utilization patterns of young and old soil $\mathrm{C}$ by microorganisms caused by temperature and $\mathrm{N}$ additions.

Biogeochemistry. 67: 235-248. 


\section{Chapter 6: Soil Microbial Relative Abundance Shows a Negative Response to Elevated Temperature and a Positive Response to Increased Moisture ${ }^{5}$}

\subsection{Abstract}

Climate change may impact soil microbial community structure by changing the abundance of different microorganisms in the soil. Prior research from soil warming studies indicates that fungi decrease in relative abundance when soils are warmed, however the majority of these studies have had a concurrent decrease in soil moisture with warming. Climate change will likely alter precipitation patterns in addition to causing higher global temperatures. It is therefore important to understand how warming and moisture impact microbial communities independently and in concert. We sampled soils from a 2 x 2 fully factorial soil warming $\left(+4-5{ }^{\circ} \mathrm{C}\right)$ and moisture addition experiment $(+30 \%$ of average growing season precipitation) in May, August and October over the course of two years to determine how the microbial community responds to elevated temperature and increased moisture inputs over time. We used PLFA analysis to measure relative abundances of bacteria and fungi. In general, our results show that both bacteria and fungi respond negatively to elevated temperature and positively to moisture addition. Fungal and bacterial markers decreased by $10 \%$ in heated versus unheated soils. Fungal markers increased by $10 \%$ in plots with moisture addition versus plots lacking moisture addition. The marker for arbuscular mycorrhizal fungi was generally $25 \%$ lower in heated plots compared to unheated plots, and 25\% greater in plots receiving moisture addition than plots without moisture addition. The mechanism driving this pattern remains unclear. With further testing of other environmental variables we will be

\footnotetext{
${ }^{5}$ Chapters $4 \& 5$ will be merged into a single article for publication in the journal Soil Biology and Biochemistry. Data from Chapter 6 will be used in this publication. The figures and text will be reformatted before submission. The order of authors for this article will be Carley Kratz, Erik Lilleskov and Andrew Burton. Carley Kratz, Andrew Burton and Erik Lilleskov have all contributed to the written portion of the text. The experimental site was overseen by Andrew Burton. Carley Kratz contributed to the methodological design and was responsible for collecting and processing data.
} 
able to understand the relationship between the microbial community and climate change in greater detail.

\subsection{Introduction}

The high taxonomic and functional diversity of soil microorganisms makes their response to climate change one of the most unpredictable, yet potentially most influential components of soil respiration. Changes in soil respiration feed back into the climate system by altering $\mathrm{CO}_{2}$ levels in the atmosphere. Although soil microbial communities contribute to soil respiration, we still do not fully understand the impact of climate change on soil microbial communities. Soil microorganisms may respond to climate change in both direct and indirect ways (Bardgett et al. 2008). The soil microbial community may not only change in response to elevated temperature and altered moisture regimes, but also to secondary changes in carbon and nutrient cycling related to climate change. We now have the ability to sequence the genes of soil microorganisms to discover the genetic variation present in the community however, yet there is still relatively known about the functional roles of the majority of microbial species (Torsvik and Øvreås 2002). There is likely functional redundancy in the soil microbial community, so that when the relative abundance of one group of microorganisms declines, the relative abundance of another group increases (Nannipieri et al. 2003). There are some broad groups of microorganisms, namely fungi and bacteria, which differ in their capacity break down different types of carbon compounds in the soil. For example, soil fungi produce many enzymes that alter the structure of recalcitrant soil compounds, such as lignin (Kellner et al. 2010). Changes in the relative abundance of broad groups of microorganisms may impact the cycling of soil carbon and nutrients (Zak et al. 2011).

Phospholipid fatty acid (PLFA) analysis places microorganisms into broadly defined classes, and is often used to determine how the microbial community shifts in relation to environmental variables. In the past, soil-warming studies have used PLFA analyses to monitor changes in the soil microbial community structure in response to higher soil temperatures. For instance, one of the long-term soil 
warming studies in a temperate hardwood forest in Massachusetts has shown an increase in the relative abundance of gram-negative bacteria and actinomycetes and a decrease in fungi due to warming (Frey et al. 2008). Moisture content was lower in the heated plots, a confounding factor in many soil-warming studies. Fungi generally decrease in abundance in warming studies in which soil moisture also decreases with warming (Rinnan et al. 2007, Clemmensen et al. 2006, Frey et al. 2008, Allison and Treseder 2008). Climate change will also alter precipitation regimes, however models indicate that both the magnitude and timing of precipitation events may vary depending on the region in question.

This study was conducted at an experimental site in northern Michigan, which employs a fully factorial design, with both warming treatments and moisture addition treatments that reflect the climate predicted for the region over the next century (Christensen et al. 2007). The combination of treatments allows us to determine the independent impacts that warming and moisture have on the microbial community structure in addition to any combined effect of the two treatments. Changes in the structure of the microbial community may ultimately have consequences for how carbon and nutrients are cycled in these northern hardwood forests.

We predicted that higher soil temperatures would cause the microbial community structure to shift. Based on a study from a similar forest (Frey et al. 2008) bacteria in general, and gram-negative bacteria and actinomycetes specifically, would show an increase in relative abundance to higher soil temperatures. Warming treatments without moisture addition would show a decline in fungal relative abundance due to water limitations. Where water is limiting under elevated soil temperature the microbial community composition will shift to favor bacteria, which are more drought tolerant compared to fungi. Fungi will increase in relative abundance compared to bacteria when more soil moisture is available. In combined heat and moisture addition treatments, fungal relative abundance would not change relative to the control, but bacterial relative abundance would respond positively to the combined treatment versus the control treatment. 


\subsection{Methods}

A climate change manipulation study was initiated in September 2010 at the Ford Forestry Center in the Upper Peninsula of Michigan. This hardwood forest has been managed for Acer saccharum Marsh. timber production and was last thinned ten years ago. Michigan Technological University's Ford Forestry Center is located at $46^{\circ} 38^{\prime} 26^{\prime \prime} \mathrm{N} 88^{\circ} 29^{\prime} 01^{\prime \prime} \mathrm{W}$ and $\sim 400 \mathrm{~m}$ elevation. Mean annual temperature in the area is $4.9^{\circ} \mathrm{C}$, with a growing season (May through September) average temperature of $15^{\circ} \mathrm{C}$. The area receives on average $879 \mathrm{~mm}$ of precipitation annually, with $401 \mathrm{~mm}$ of precipitation falling during the growing season (Burton et al. 2012). Sugar maple (Acer saccharum Marsh.) dominates the overstory (trees $>5.0 \mathrm{~cm}$ diameter), contributing to $89 \%$ of the overstory basal area. American elm (Ulmus americana L.), eastern hemlock (Tsuga canadensis (L.) Carr.), ironwood (Ostrya virginiana (Mill.) K. Koch) and yellow birch (Betula alleghaniensis Britton) comprise the remainder. Soils are Kallio cobbly silt loams (Coarse-loamy, mixed, superactive, frigid Oxyaquic Fragiorthods) (Burton et al. 2012).

The experiment has a fully factorial design with three blocks under the following treatment conditions; ambient conditions, soil heating with infrared lamps $\left(+4-5{ }^{\circ} \mathrm{C}\right)$, moisture addition $(+30 \%$ of ambient growing season precipitation) and soil heating plus moisture addition. The plots are $10 \mathrm{~m} \times 10 \mathrm{~m}$ with no replication within block. Soil warming was accomplished via infrared lamps suspended $1.5 \mathrm{~m}$ above the soil surface. The moisture addition represents the upper limit of potential precipitation predicted by IPCC models (Chistensen et al. 2007), and should replace any evaporative loss associated with the elevated temperature for the majority of the growing season. Precipitation was harvested from a rooftop catchment of a nearby building, stored in large holding tanks, and distributed approximately weekly onto plots using a sprinkler system. Moisture addition occurred during rain events when possible, in order to mimic natural patterns of precipitation.

Soils were collected in 2011 and 2012, during the first and second full years of experimental treatments. Soil collections were performed in May, August and October of each year. In 2011 five soil cores with a $1 \mathrm{~cm}$ diameter and $10 \mathrm{~cm}$ depth 
were taken from each plot, totaling 60 soil samples per month. The sampling design was altered in 2012 to complement measurement of soil nitrogen mineralization and to minimize disturbance to the experimental plots. In 2012 three soil cores with a $5 \mathrm{~cm}$ diameter and $10 \mathrm{~cm}$ depth were taken for each plot, for a total of 36 soils samples per month. The soil lacks an O horizon, so only mineral soil from the A horizon was sampled. Samples were hand sorted to remove roots, rock and insects. Soils were kept on ice and transported back to the laboratory at Michigan Technological University within 4 hours of collection, at which point they were stored at $-20^{\circ} \mathrm{C}$. Samples were freeze dried before PLFA analysis. A subsample of $1 \mathrm{~g}$ was taken from each sample. Subsamples from the same plot were pooled and homogenized before analysis resulting in a $5 \mathrm{~g}$ soil sample for each plot in 2011 and a $3 \mathrm{~g}$ soil sample for each plot in 2012.

PLFA analysis was used to understand how the microbial biomass of the community is partitioned into fungal and bacterial groups of soil microorganisms. The procedure was carried out according to Frostegård et al. (1991). Approximately $2.5 \mathrm{~g}$ of freeze dried soil was used for PLFA analysis. Briefly, cells in the soil were lysed with chloroform and methanol and total lipids were extracted in the chloroform layer. Phospholipid, glycolipid and neutral lipid fractions were separated with silicic acid chromatography. Phospholipids were methylated and the length and structures of the resulting fatty acid methyl ester (FAME) chains and their relative abundances were quantified using a gas chromatograph with a flame ionization detector (Agilent 6850). The FAME 19:0 was used as an internal standard in order to quantify the amount of individual FAME biomarkers in each sample. The amount of individual FAME biomarkers was used as an indicator of biomass and relative abundance of different groups of microorganisms, following Brockett et al. (2012) and Frey et al (2008) (Table 6.1).

Statistical analyses were conducted using RStudio (http://www.rstudio.com). A repeated measures analysis of variance (ANOVA) was conducted using the aov function in $\mathrm{R}$ to examine the impact of block, added heat, added water, and the interaction of heat and added water between plots. Within plots the main effect of 
the date of sampling, the interaction between date and block, and the two-way interactions between date and heat, and added water were analyzed. A three-way interaction between date, heat and added moisture was also examined. Post-hoc analyses were not performed due to the lack of independence between sampling units. Alpha was set at 0.05. Figures were produced using SPSS version 21.0. Figures were only produced to illustrate statistically significant patterns.

\subsection{Results}

Heated treatments had significantly lower FAME content versus unheated treatments for total FAME content, total bacterial FAME content, total fungal FAME

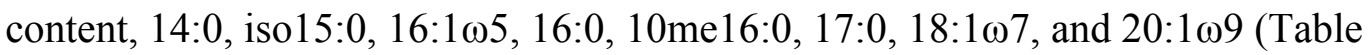
6.1). Moisture addition treatments had significantly greater FAME content than treatments lacking moisture addition for the total FAME content, the total fungal

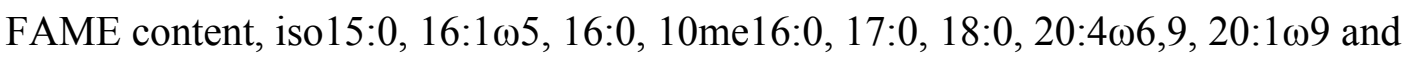
24:0 (Table 6.1). The combined heat and moisture addition treatment had lower

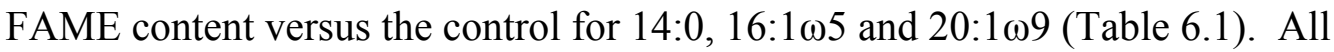
FAME markers and summary values showed significant differences by month. Significant differences among blocks were found for total fungal FAME content, the bacterial to fungal ratio, 14:0, 15:0, 16:1 $1 \omega 5,16: 0,17: 0,18: 2 \omega 6,18: 1 \omega 7,22: 0$ and 24:0 (data not shown).

The total FAME content was 10\% lower in heated versus unheated plots and $10 \%$ greater in plots receiving moisture addition compared to those without moisture addition (Figure 6.1). Total FAME content also differed significantly by month (Figure 6.1). The total bacterial FAME was approximately $10 \%$ lower in heated versus unheated plots and varied significantly by month (Figure 6.2). The total fungal FAME content was also 10\% lower in heated versus unheated plots, was $10 \%$ greater in plots receiving moisture addition compared to those without moisture addition, and varied significantly by month (Figure 6.3). The total bacterial and total fungal FAME markers showed similar temporal patterns to the total FAME content of the soil. FAME content was greatest in August 2011 and lowest in May and August 2012. The bacterial to fungal ratio differed significantly by month, with 
more bacteria relative to fungi present in May and August 2012 versus other months (Figure 6.4).

The general bacterial FAME markers tended to respond negatively to higher temperatures and positively to increased moisture input. The bacterial FAME 14:0 was generally lower in heated versus unheated plots, and lower in the combined moisture addition and heated plots versus the control, with the exception of October 2012 where the heated treatments had the greatest 14:0 content (Figure 6.5). The bacterial FAME 14:0 also differed significantly by month, with relatively high 14:0 content in May and August 2011 and low content in October 2011 (Figure 6.5). The bacterial FAME markers a15:0, a17:0, iso17:0 and cy17:0 only showed significant differences by month (Figures 6.6, 6.7 and 6.8 and 6.9 respectively). The bacterial FAME markers a15:0 and a17:0 were greatest in August 2011 and lowest in May 2012 (Figures 6.6 and 6.7). The bacterial FAME markers iso 17:0 and cy 17:0 were also relatively low in 2012 and greatest in May 2011 (Figures 6.8 and 6.9, respectively).

The more specific bacterial FAME markers also tended to respond negatively to higher temperatures and negatively to increased moisture input. Specific markers for gram-positive bacteria, gram-negative bacteria and actinomycetes tended to be greater in 2011 versus 2012. The gram-positive bacterial FAME iso15:0 was generally lower in heated versus unheated plots, greater in plots receiving moisture addition compared to those without moisture addition, and differed significantly by month (Figure 6.10). The iso 15:0 content tended to be lower in 2012 versus 2011

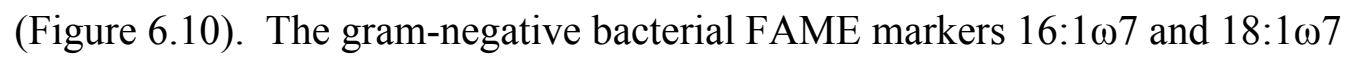
showed a similar significant temporal pattern being lower in 2012 versus 2011 (Figures 6.11 and 6.12, respectively). The gram-negative marker 18:1 $\omega 7$ was also significantly lower in heated versus unheated plots in most months, with the exception of October 2012 which showed no difference in 18:1 107 content between warming treatments (Figure 6.12). The actinomycete marker 10me16:0 was generally lower in heated versus unheated plots and was significantly greater in plots receiving moisture addition versus those without added moisture, although this was 
not true for each month individually (Figure 6.13). The actinomycete FAME markers 10me16:0 and 10me18:0 tended to be lower in 2012 versus 2011 and were lowest in May 2012 (Figure 6.13 and 6.14, respectively).

The individual fungal FAME markers followed a similar pattern as the bacterial markers and tended to decrease with elevated temperature and increase with added moisture input. In general, the arbuscular mycorrhizal fungal marker 16:1 05 was $25 \%$ lower in heated versus unheated plots, $25 \%$ greater in moisture addition plots compared to plots without moisture addition, and $15 \%$ lower in the combined heat and moisture addition treatment versus the control (Figure 6.15). In October 2012 16:1 $\omega 5$ content was greater in all of the experimental treatments versus the

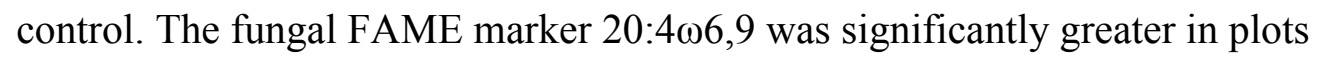
receiving moisture addition versus those without moisture addition (Figure 6.16). The arbuscular mycorrhizal fungal marker 16:1 $\omega 5$, and the general fungal markers,

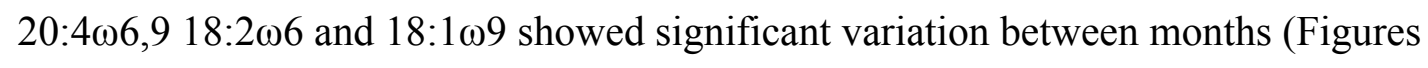
$6.15,6.16,6.17$ and 6.18, respectively). The arbuscular mycorrhizal fungal marker 16:1 $\omega 5$ was significantly greater in May 2011 versus other months and lowest in

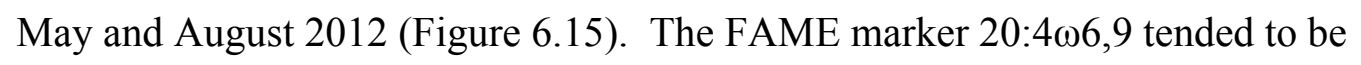
lower in 2012 versus 2011, and was significantly lower in August 2012 versus other

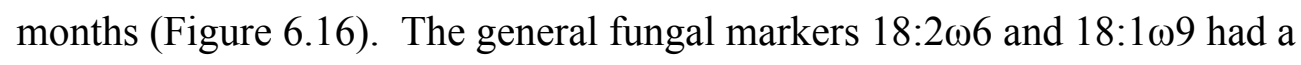
significantly greater FAME content in August 2011 and lower content in May and August 2012 versus other months (Figures 6.17 and 6.18, respectively).

The individual total FAME markers also tended to decrease in response to elevated temperature and increase in response to additional moisture inputs. The total FAME markers 16:0, 17:0 and 20:1 19 were typically significantly lower in heated versus unheated plots (Figures 6.19, 6.20 and 6.21, respectively). The total FAME markers 16:0, 17:0, 20:1 $199,18: 0$ and 24:0 were significantly greater in moisture addition treatments versus treatments without moisture addition (Figures $6.19,6.20,6.21,6.22$ and 6.23, respectively). The total FAME 20:1 $\omega 9$ was also lower in the combined heat and moisture addition treatment versus the control and there was a significant interaction between month and heat (Figure 6.21). This is 
likely due to a much greater 20:1 $\omega 9$ content in the heated treatments versus the unheated treatments in October 2011.

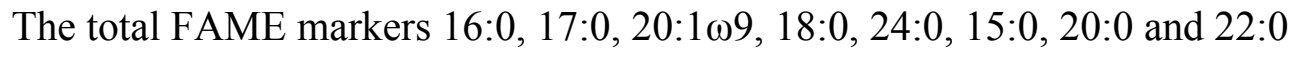
varied significantly by month, but did not follow a consistent temporal pattern (Figures 6.19, 6.20, 6.21, 6.22, 6.23, 6.24, 6.25 and 6.26, respectively). The general FAME markers 18:0, 24:0, 15:0 and 22:0 were all significantly lower in 2012 versus 2011 (Figures 6.22, 6.23, 6.24 and 6.26 respectively), following a similar pattern as the bacterial markers. The markers 16:0 and 17:0 were significantly lower in May and August 2012 versus other months (Figures 6.19 and 6.20). The total FAME marker 20:0 was significantly greater in October 2012 versus other months (Figure 6.25). The total FAME marker 20:109 was significantly greater in May 2011 compared to other months (Figure 6.21).

\subsection{Discussion}

The results generally support our predictions in regards to fungi. Fungal FAME content was significantly lower in heated treatments when all fungal markers were grouped together. This is in accordance with past studies (Rinnan et al. 2007, Clemmensen et al. 2006, Frey et al. 2008, Allison and Treseder 2008), although these studies were conducted in a variety of different ecosystems. The only individual fungal marker that had significantly lower FAME content in heated versus

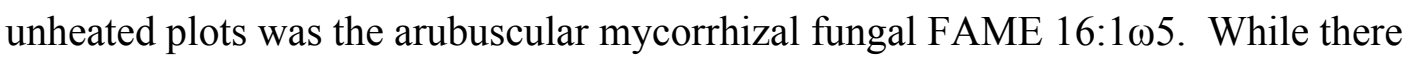
was no statistically significant difference between heated and unheated plots for the other fungal markers, there was a general trend towards lower FAME content in heated versus unheated pots for these markers individually. It is important to note that $16: 1 \omega 5$ is the only FAME that we used to estimate arbuscular mycorrhizal fungi individually (according to Olsson et al. 1995). In this ecosystem arbuscular mycorrhizae are more frequent than other types of mycorrhizal associations because Acer saccharum is the most prevalent tree species. This differs from previous soil warming studies where ectomycorrhizal and ericoid mycorrhizal relationships are prevalent (Rinnan et al. 2007, Clemmensen et al. 2006. Allison and Treseder 2008). Frey et al. (2008) reported PLFA results from a soil warming study in a northern 
hardwood forest in Massachusetts with both ectomycorrhizal and arbuscular mycorrhizal relationships. The results from that study indicated that arbuscular mycorrhizal fungi decreased along with all other fungal markers. It is possible that other types of mycorrhizal fungi respond in a similar manner as arbuscular mycorrhizal fungi, however this determination cannot be made using PLFA analysis. Available soil nitrogen content may also impact the abundance of arbuscular mycorrhizal fungi (Van Diepen 2008), and nitrogen mineralization has increased with warming during the current experiment (Jarvi and Burton 2013).

We also predicted that more fungi would be present in plots receiving moisture addition versus plots without moisture addition, based on possible interactions between warming and drying in previous soil warming studies (Rinnan et al. 2007, Clemmensen et al. 2006, Frey et al. 2008, Allison and Treseder 2008). This pattern was present for the total fungal FAME content, 16:1 $\omega 5$ content, and 20:4 $\omega 6,9$ content. There was a trend towards higher FAME content in moisture addition treatments versus treatments without moisture addition for the other fungal markers, and although this trend was not statistically significant, it is biologically relevant. We predicted that the fungal abundance would not be different between the combined heat and moisture addition treatment versus the control. There was little difference in the FAME content for fungi between the control and combined heat and moisture addition treatment, with the exception of the arbuscular mycorrhizal fungal marker 16:1 $\omega 5$. Contrary to our predications, the combined heat and moisture addition treatment had significantly lower amounts of $16: 1 \omega 5$ versus the control. It is possible that arbuscular mycorrhizal fungi are outcompeted by bacteria when both heat and moisture are higher. It is also possible that there is increased feeding on fungal hyphae when higher temperature and moisture conditions are present. Briones et al. (2009) found that the invertebrate community shifted in heated versus unheated plots in a grassland mesocosm experiment, favoring fungivorous mites and nematodes over epigeic earthworms.

The results do not support our predictions regarding the bacterial community. We anticipated that bacteria would increase in abundance due to warming. This was 
not the case for the total bacterial FAME content or the content of any individual marker. Most bacterial markers actually trended towards lower FAME content in the heated versus unheated treatments. The individual bacterial markers 14:0, iso15:0 and 18:107 had significantly lower FAME content in the heated versus unheated treatments. The actinomycete marker 10me16:0 also had significantly lower FAME content in the heated versus unheated treatments, contrary to our predictions. Additionally, heat had a negative effect on the total FAME content including both bacteria and fungi. This indicates that the microbial community as a whole is suppressed under warmer conditions. It is important to remember that FAME content is not synonymous with the metabolic activity of soil microorganisms. Although there is less carbon being stored in the microbial biomass in heated versus unheated treatments, it is possible that the microorganisms that are present in the heated treatments have metabolic rates that match or surpass the metabolic rates of microorganisms in the unheated treatments. These higher metabolic rates would evident in quick turnover of the microbial carbon pool.

Moisture addition had a positive effect on the total amount of FAME present in the soil. More microbial biomass was present in plots receiving moisture addition than those lacking moisture addition. It is possible that increased moisture allowed nutrients to diffuse more rapidly through the soil (Allison 2005). The moisture would allow more microorganisms to grow because of increased nutrient supply and because water provides a medium for the growth and reproduction of microorganisms. Total bacterial FAME content, however was not significantly impacted by moisture addition. The only significantly higher bacterial FAME contents in the moisture addition treatments versus treatments without moisture addition were the gram-positive marker iso15:0 and the actinomycete marker 10me16:0. We expected higher abundance of bacterial FAME in plots with combined heat and moisture addition versus the control. Most bacterial FAME markers did not differ between the combined treatment and control, with the exception of 14:0, which contrary to our prediction had a lower content in the combined treatment versus the control. 
It is not surprising that the month of sampling had a significant impact on all FAME markers. This illustrates the importance of measuring factors related to the microbial community throughout time, rather than at a single time point. Some seasonal and yearly variation has been reported in studies using PLFA analysis (Björk et al. 2008, Schindlbacher et al. 2011), but studies that examine soil PLFA analyses over multiple time points are rare. Microbial communities typically change through time, influenced by conditions other than experimental treatments. In order to see clear patterns between treatments, it is necessary to sample the microbial community repeatedly. It is noteworthy that FAME markers generally had a lower abundance in 2012 versus 2011. It is possible that the prolonged heating treatments caused the overall average microbial biomass to drop in the second year of experimental manipulation. There was also a drought in 2011, which may have impacted the microbial biomass negatively in 2012. It has been suggested that there is a microbial memory to past environmental conditions (Wolf et al. 2008). Microorganisms living in a soil with a past history of drought could respond differently than microorganisms in soils without a drought history. In 2012, the microbial community may not have produced a biomass as large as in 2011 because the enzymes and molecules that make up the cell structure were evolved under drought conditions in 2011.

The results from the study by Frey et al. (2008) are most comparable to ours, since both studies occurred in temperate forests of Eastern North America. However, in that study organic and mineral horizons were partitioned for analysis and only one time point was used. In the current study, no organic layer was present and soil PLFA analyses were performed six times over two growing seasons, so we anticipated that our results would vary from those of Frey et al. (2008). Some bacterial PLFA markers in that study increased with soil warming in the mineral soil layer, contrary to our results.

\subsection{Conclusion}

As hypothesized, fungi responded negatively to higher temperatures and positively to increased moisture as independent factors. Contrary to expectations, 
bacteria responded in a similar manner to fungi. Bacterial FAME content was generally lower in plots with higher temperatures and higher in plots with moisture addition. Microbial biomass decreases in response to soil warming. The functional role that soil microorganisms play in carbon and nutrient cycling may be altered by this reduction in biomass. The bacterial and fungal community composition may be altered at a finer scale than can be resolved using PLFA analyses. Future testing should focus on determining the active microbial community at a genus or species level scale using genomic methods. It is possible that the availability of nitrogen, or other carbon and nutrient resources have secondary impacts on the structure of the microbial community. Future studies that relate the functional capabilities of soil microorganisms to the quantity and quality of carbon and nutrient resources at a genomic level will increase the depth of knowledge about the role that soil microbial communities may play under climate change conditions. 
Table 6.1. Summary of statistically significant results of repeated measures ANOVA. The type of PLFA marker is listed in the second column. Statistical significance was measured at alpha $=0.05$, and $p$-values less than alpha are shown.

\begin{tabular}{|c|c|c|c|c|c|c|c|}
\hline & $\begin{array}{l}\text { PLFA marker } \\
\text { type }\end{array}$ & Block & Heat & Water & $\begin{array}{l}\text { Heat X } \\
\text { Water }\end{array}$ & Month & $\begin{array}{l}\text { Month } \\
\text { X Heat }\end{array}$ \\
\hline Total & Summary & & 0.030 & 0.043 & & $<0.001$ & \\
\hline $\begin{array}{l}\text { Bacterial } \\
\text { Total }\end{array}$ & Summary & & 0.037 & & & 0.010 & \\
\hline $\begin{array}{l}\text { Fungal } \\
\text { Total }\end{array}$ & Summary & 0.028 & 0.044 & 0.037 & & $<0.001$ & \\
\hline $\begin{array}{l}\text { Bacteria: } \\
\text { Fungi }\end{array}$ & Summary & 0.021 & & & & $<0.001$ & \\
\hline 14:0 & Bacteria & 0.028 & 0.019 & & 0.015 & $<0.001$ & \\
\hline a15:0 & Bacteria & & & & & $<0.001$ & \\
\hline iso17:0 & Bacteria & & & & & 0.001 & \\
\hline a17:0 & Bacteria & & & & & $<0.001$ & \\
\hline cy19:0 & Bacteria & & & & & 0.043 & \\
\hline iso15:0 & Gram + Bacteria & & 0.029 & 0.042 & & 0.003 & \\
\hline 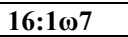 & Gram - Bacteria & & & & & $<0.001$ & \\
\hline cy17:0 & Gram - Bacteria & & & & & 0.002 & \\
\hline 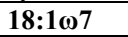 & Gram - Bacteria & 0.027 & 0.001 & & & 0.0179 & \\
\hline 10me16:0 & Actinomycetes & & 0.018 & 0.012 & & $<0.001$ & \\
\hline 10me18:0 & Actinomycetes & & & & & $<0.001$ & \\
\hline $16: 1 \omega 5$ & AMF & 0.009 & $<0.001$ & $<0.001$ & 0.005 & $<0.001$ & \\
\hline 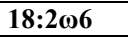 & Fungi & 0.023 & & & & $<0.001$ & \\
\hline $18: 1 \omega 9$ & Fungi & & & & & $<0.001$ & \\
\hline $20: 4 \omega 6,9$ & Fungi & & & 0.023 & & $<0.001$ & \\
\hline $15: 0$ & Total & 0.026 & & & & $<0.001$ & \\
\hline $16: 0$ & Total & 0.002 & $<0.001$ & 0.005 & & $<0.001$ & \\
\hline 17:0 & Total & 0.005 & 0.005 & 0.014 & & $<0.001$ & \\
\hline $18: 0$ & Total & & & 0.024 & & $<0.001$ & \\
\hline $20: 1 \omega 9$ & Total & & 0.003 & 0.026 & 0.015 & $<0.001$ & 0.002 \\
\hline 20:0 & Total & & & & & 0.010 & \\
\hline $22: 0$ & Total & 0.011 & & & & $<0.001$ & \\
\hline $24: 0$ & Total & 0.011 & & 0.041 & & $<0.001$ & \\
\hline
\end{tabular}




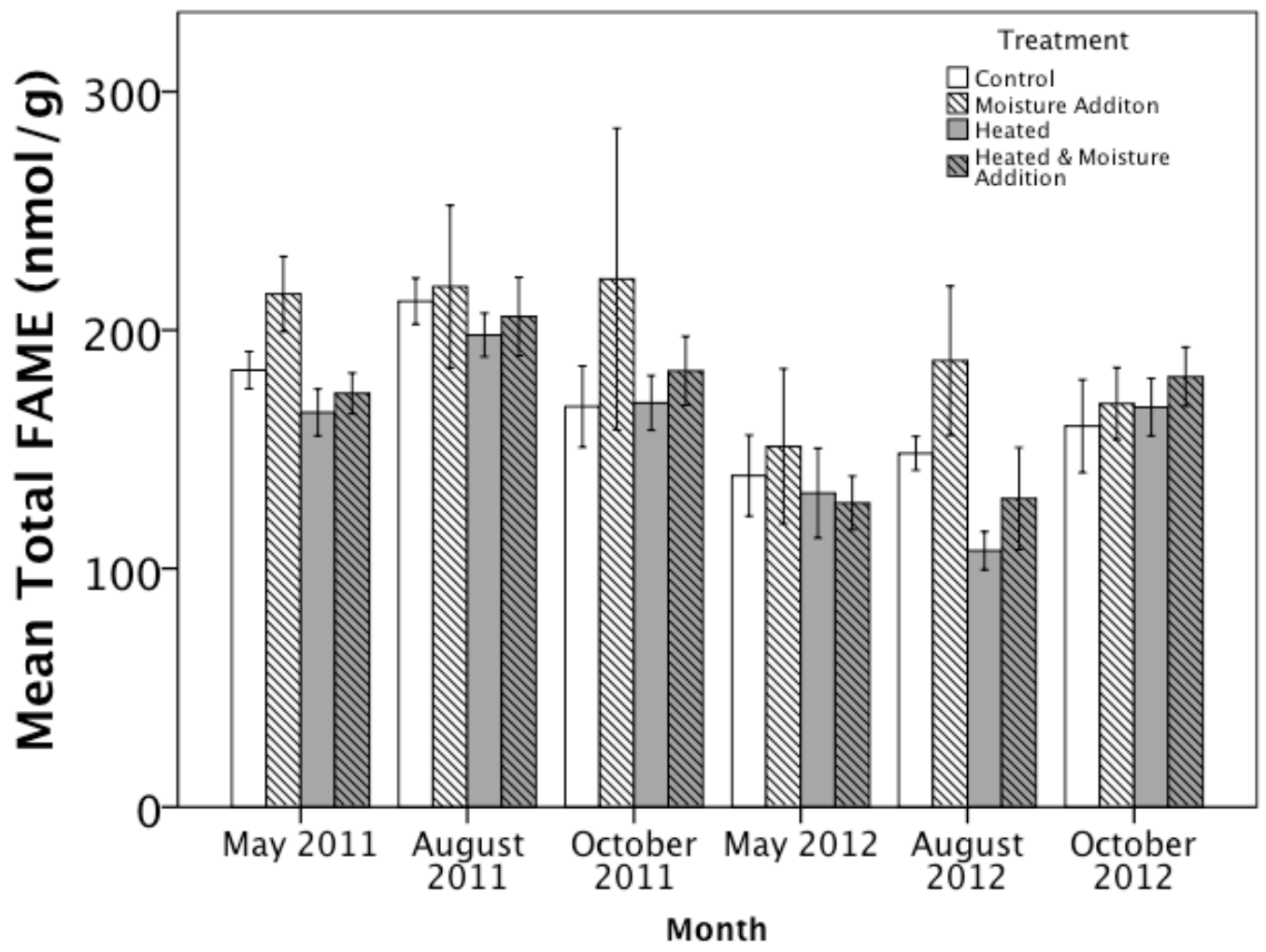

Figure 6.1 Mean total FAME content differed significantly by heat, moisture and month. Heated treatments had signficantly lower content versus unheated treatments and moisture addition treatments had significantly higher FAME content than treatments without moisture addition. FAME content was greatest in August 2011 and lowest in May and August 2012. Error bars are one standard error of the mean. 


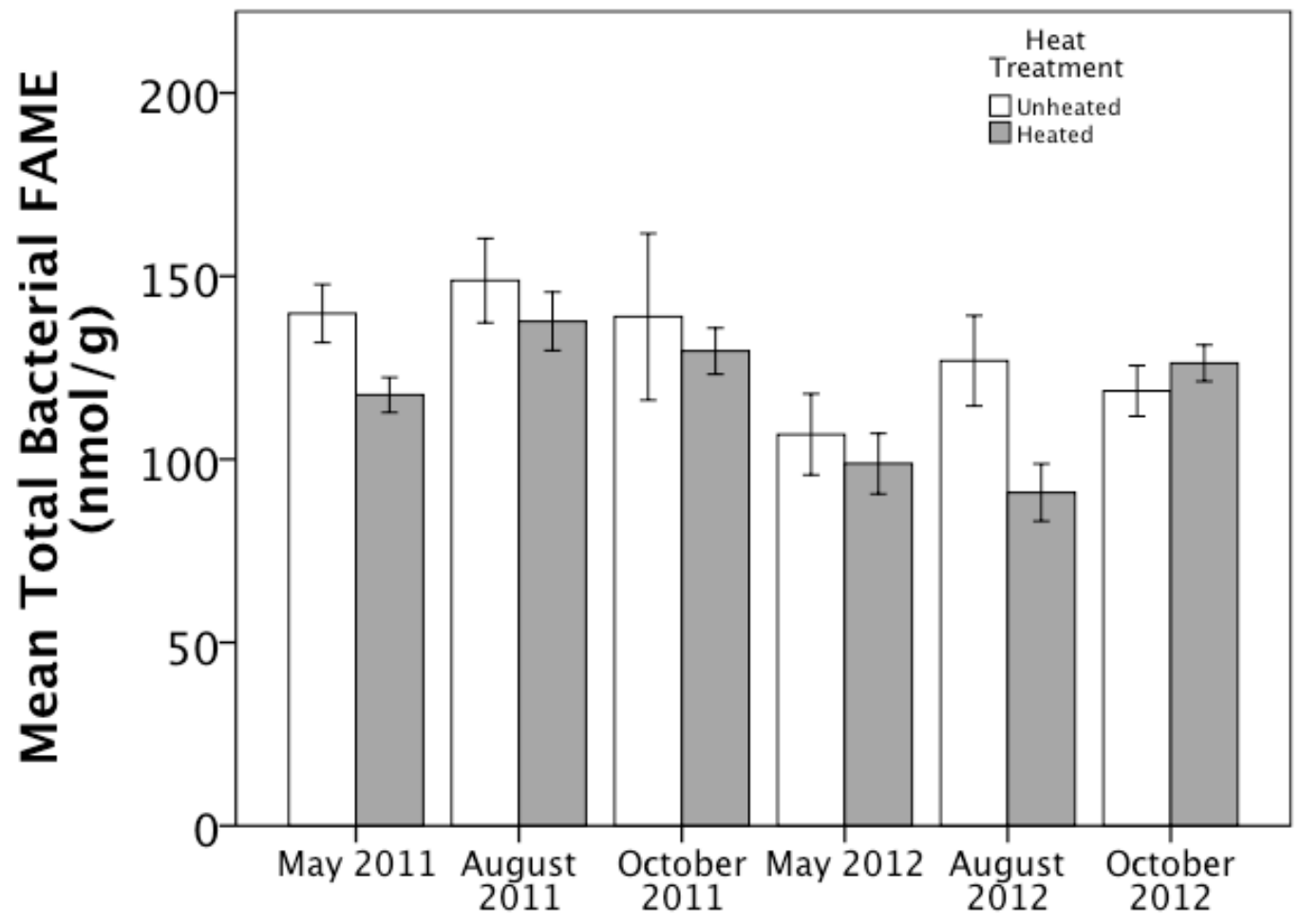

Figure 6.2 Mean total bacterial FAME content was signficantly lower in heated versus unheated plots. FAME content was greatest in August 2011 and lowest in May and August 2012. Error bars are one standard error of the mean. 


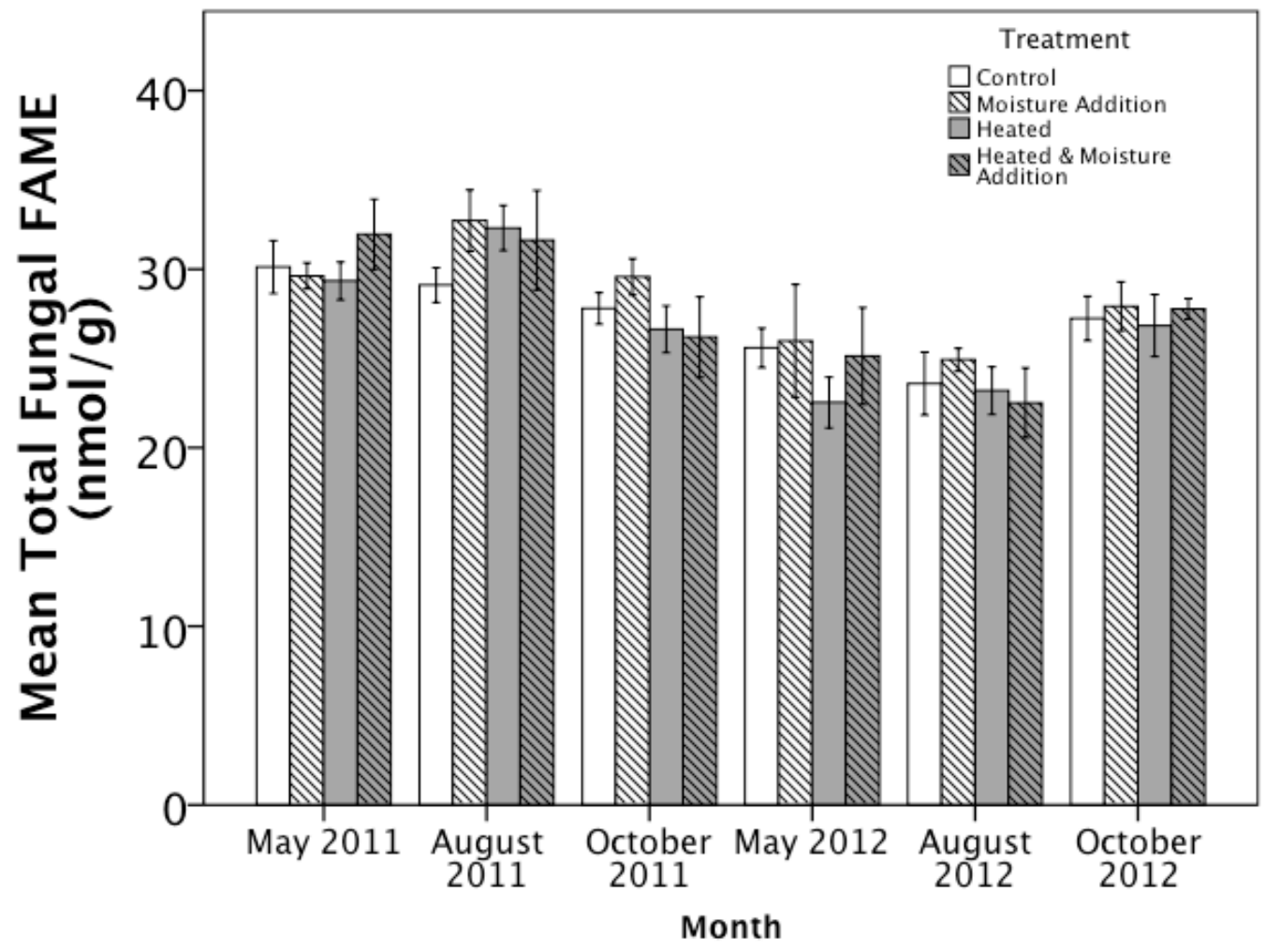

Error Bars: + /- $1 \mathrm{SE}$

Figure 6.3 Mean total fungal FAME content was signficantly lower in heated versus unheated plots and greater in plots with moisture addition than those without moisture addition. FAME content was greatest in August 2011 and lowest in May and August 2012. Error bars are one standard error of the mean. 


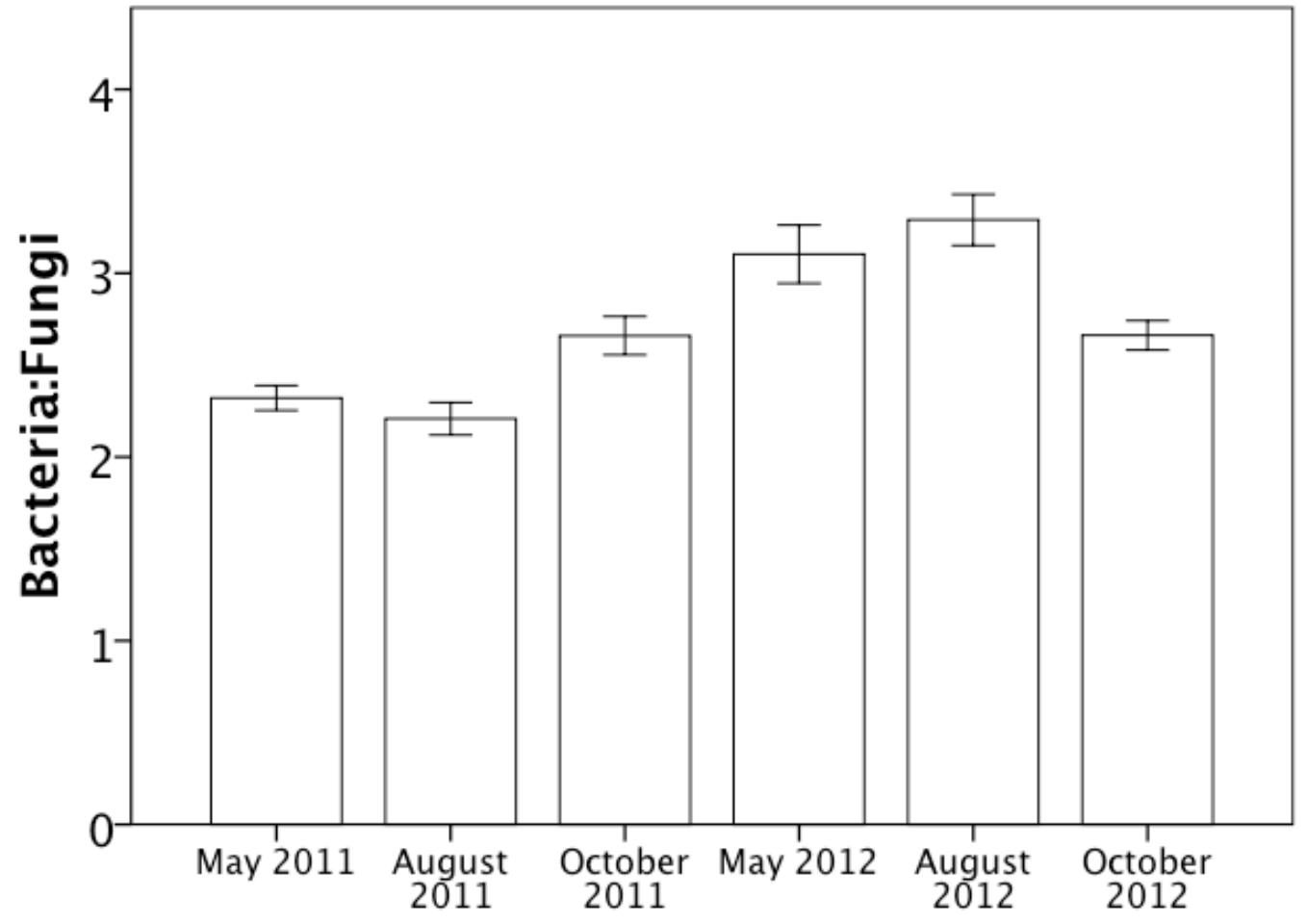

Figure 6.4 The mean ratio of bacteria to fungi differed significantly by month. More bacteria relative to fungi were present in May and August 2012 versus other months. Error bars are one standard error of the mean. 


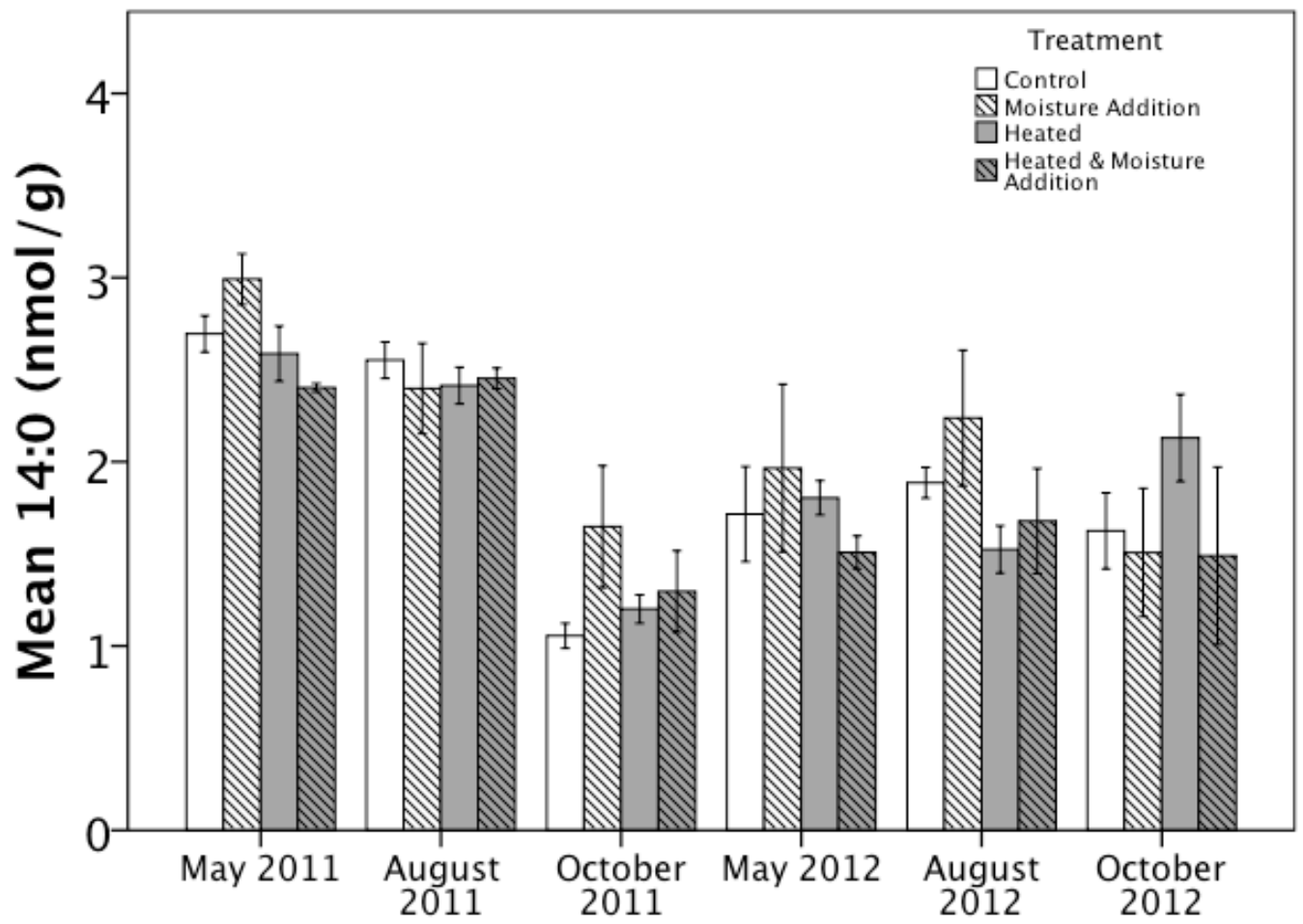

Figure 6.5 Mean bacterial FAME marker 14:0 was signficantly lower in heated versus unheated plots and greater in plots with moisture addition than those without moisture addition. FAME content was relatively high in May and August 2011 and low in October 2011 compared to other months. Error bars are one standard error of the mean. 


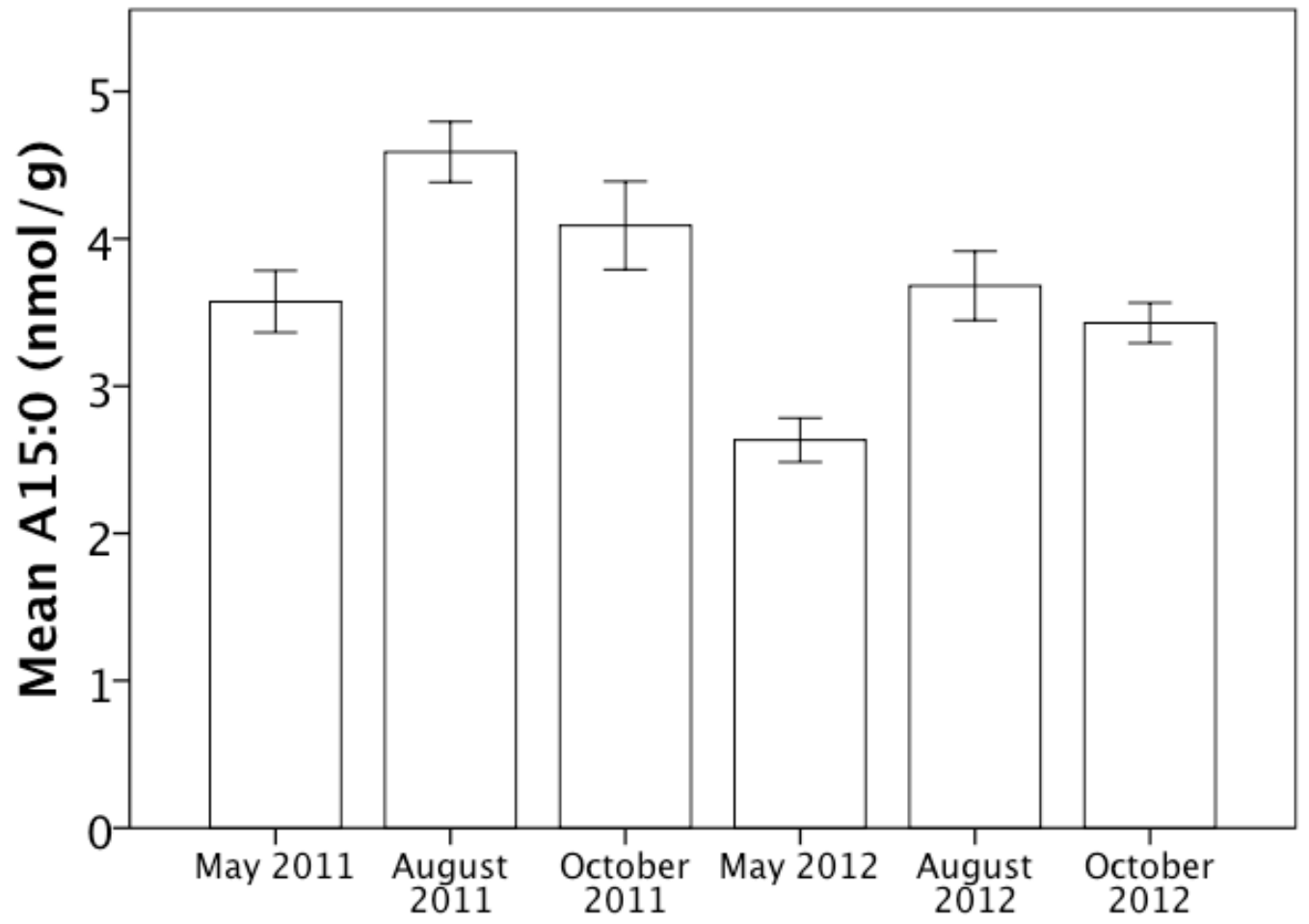

Figure 6.6 The mean bacterial FAME marker a15:0 differed significantly by month. August 2011 FAME content was greater and May 2012 content was lower compared to other months. Error bars are one standard error of the mean. 


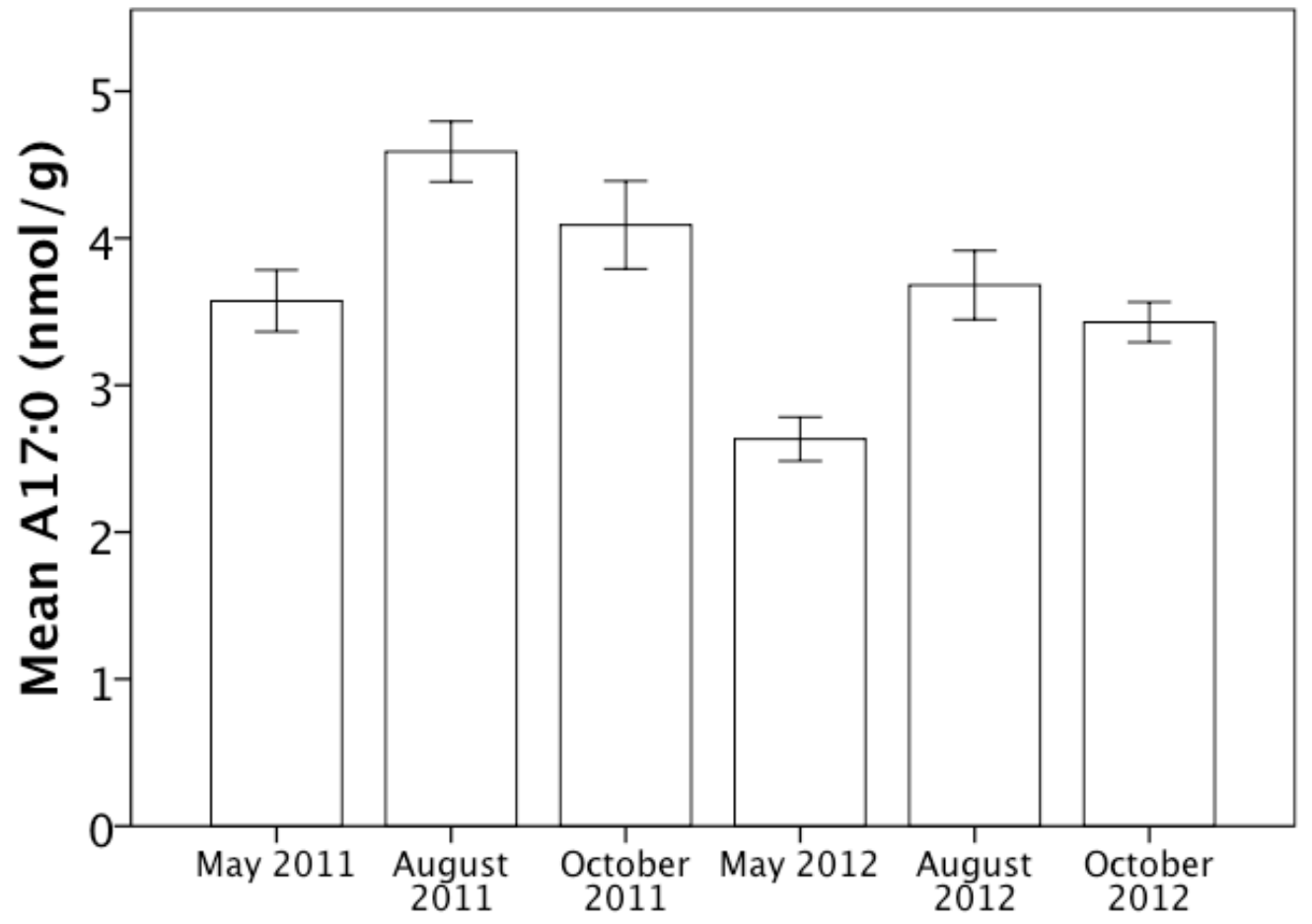

Figure 6.7 The mean bacterial FAME marker a17:0 varied significantly by month. August 2011 FAME content was greater and May 2012 content was lower compared to other months. Error bars are one standard error of the mean. 


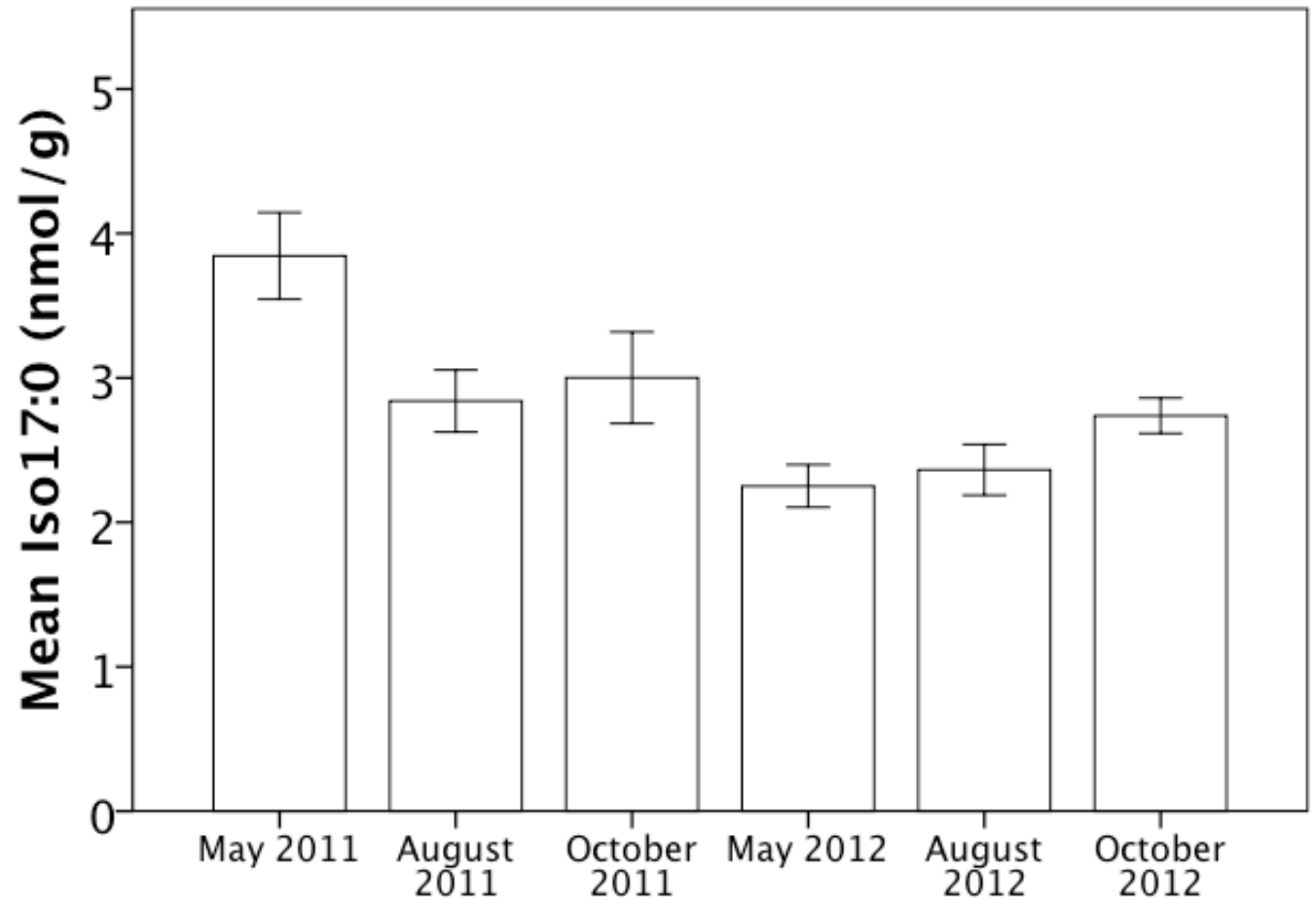

Figure 6.8 The mean bacterial FAME iso 17:0 differed significantly by month. The content in 2012 was relatively lower than 2011, and May 2011 had the highest FAME content. Error bars are one standard error of the mean. 


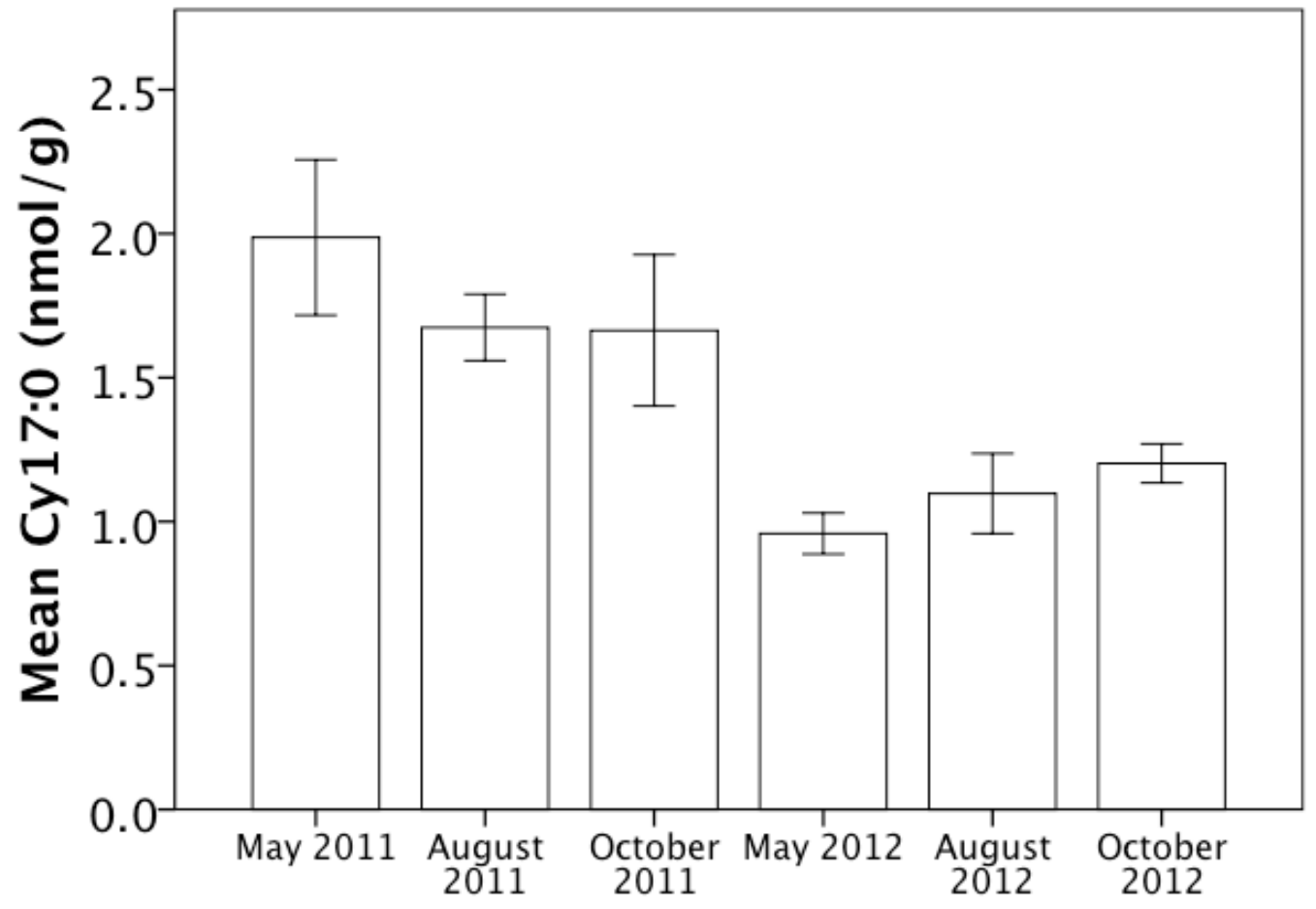

Figure 6.9 The mean bacterial FAME cy17:0 differed significantly by month. The content in 2012 was relatively lower than 2011, and May 2011 had the highest FAME content. Error bars are one standard error of the mean. 


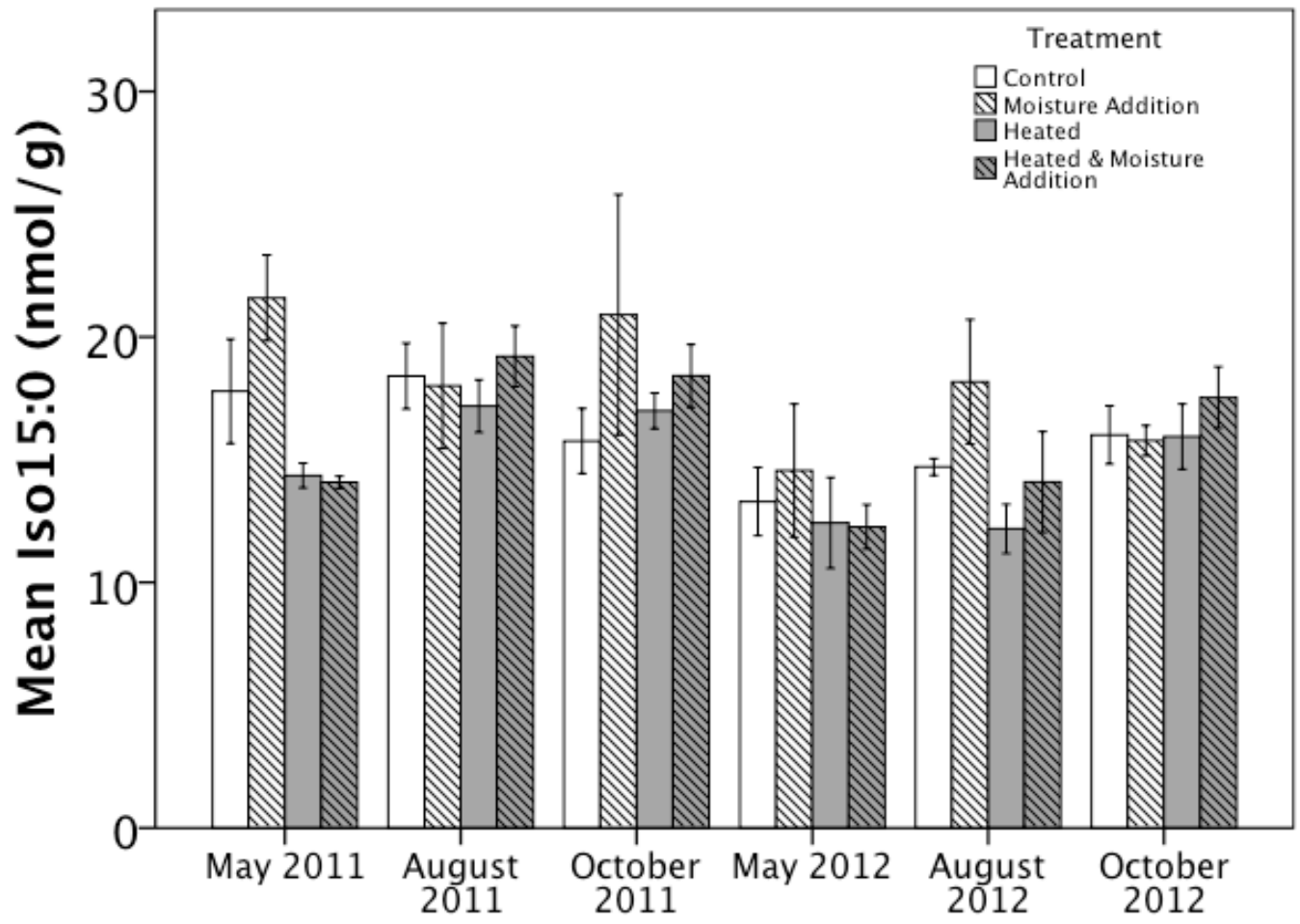

Figure 6.10 The mean gram-positive bacterial FAME iso15:0 content was lower in heated versus unheated treatments and greater in plots with moisture addition versus plots lacking moisture addition. FAME content tended to be lower in 2012 compared to 2011. Error bars are one standard error of the mean. 


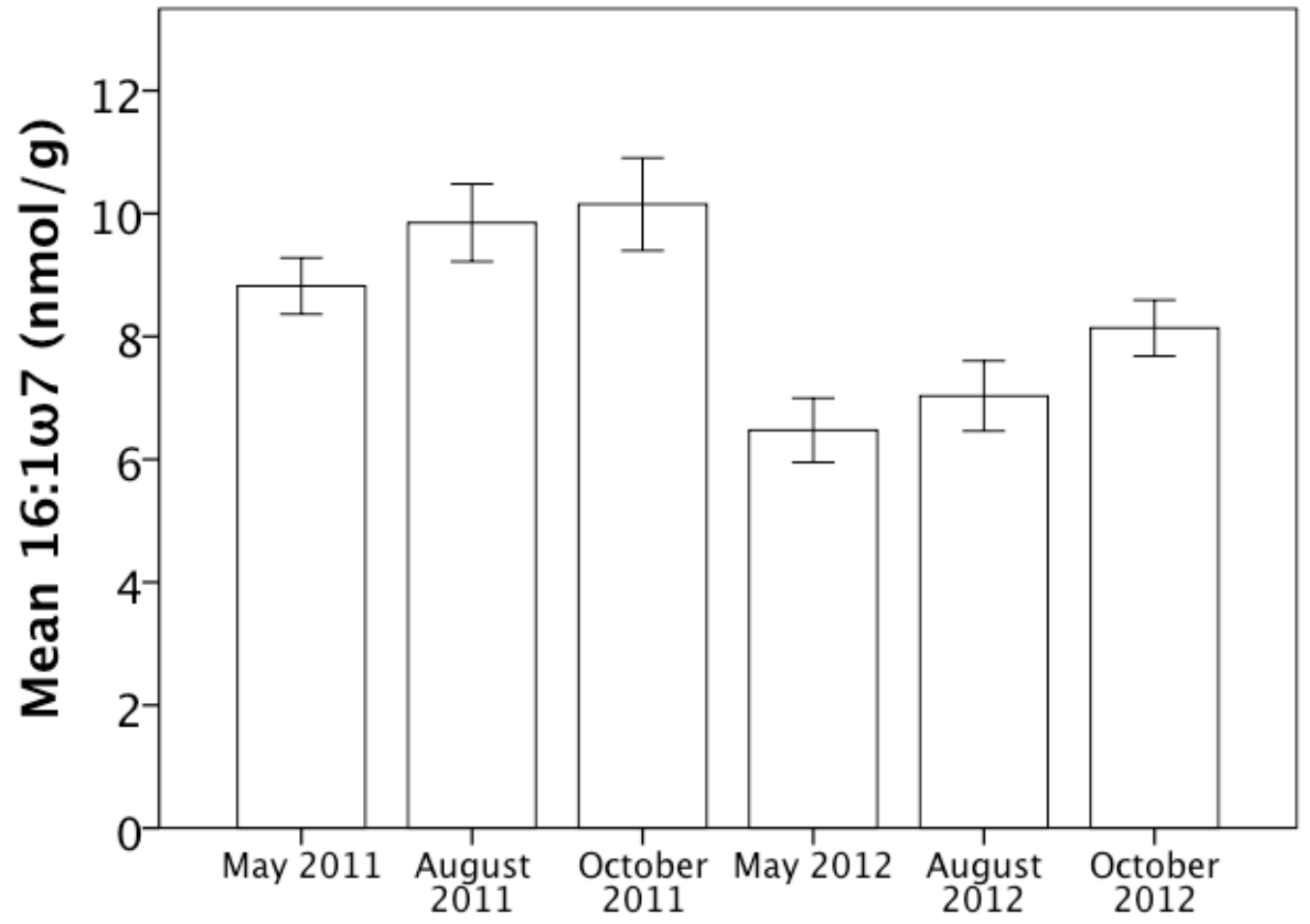

Figure 6.11 The mean gram-negative bacterial FAME 16:1 17 differed significantly by month. FAME content was lower in 2012 versus 2011. Error bars are one standard deviation of the mean. 


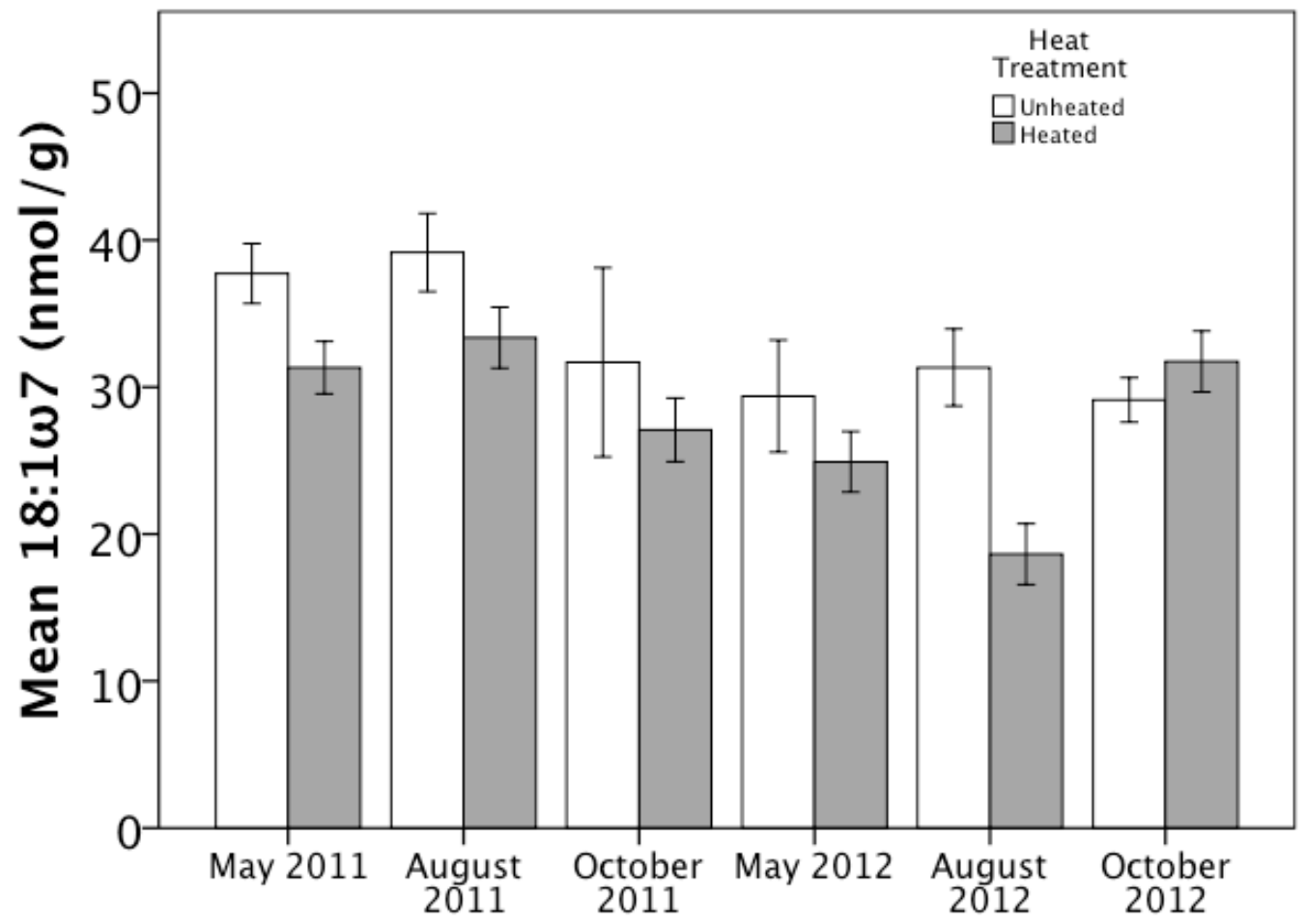

Figure 6.12 The mean gram-negative bacterial FAME 18:1 17 content was significantly lower in heated versus unheated plots. FAME content was lower in 2012 versus 2011. Error bars are one standard error of the mean. 


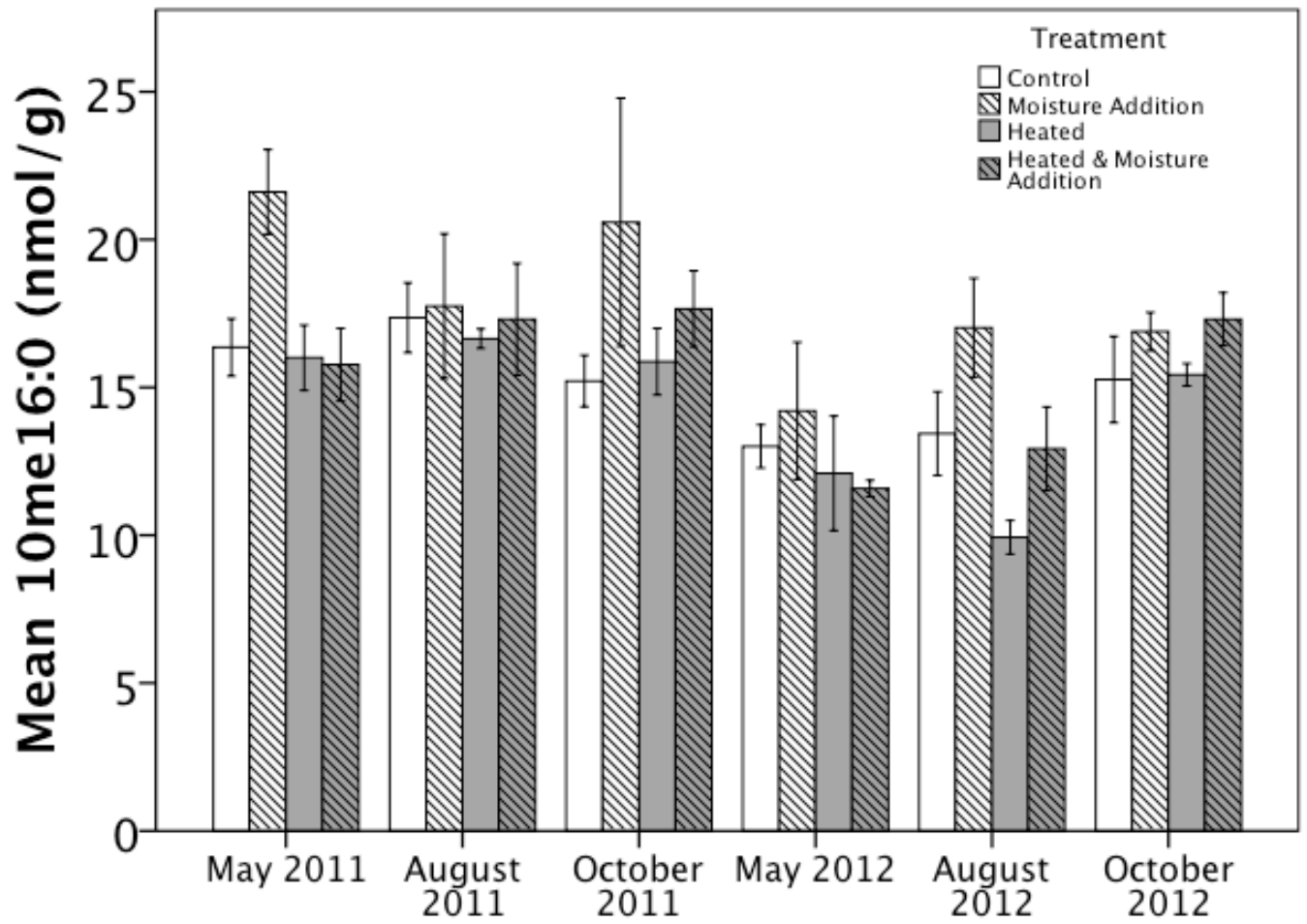

Figure 6.13 The mean actinomycete FAME marker 10me16:0 was lower in heated versus unheated plots and greater in plots with moisture addition than those lacking moisture addition. FAME content was lowest in May 2012, and tended to be greater in 2011 versus 2012. Error bars are one standard error of the mean. 


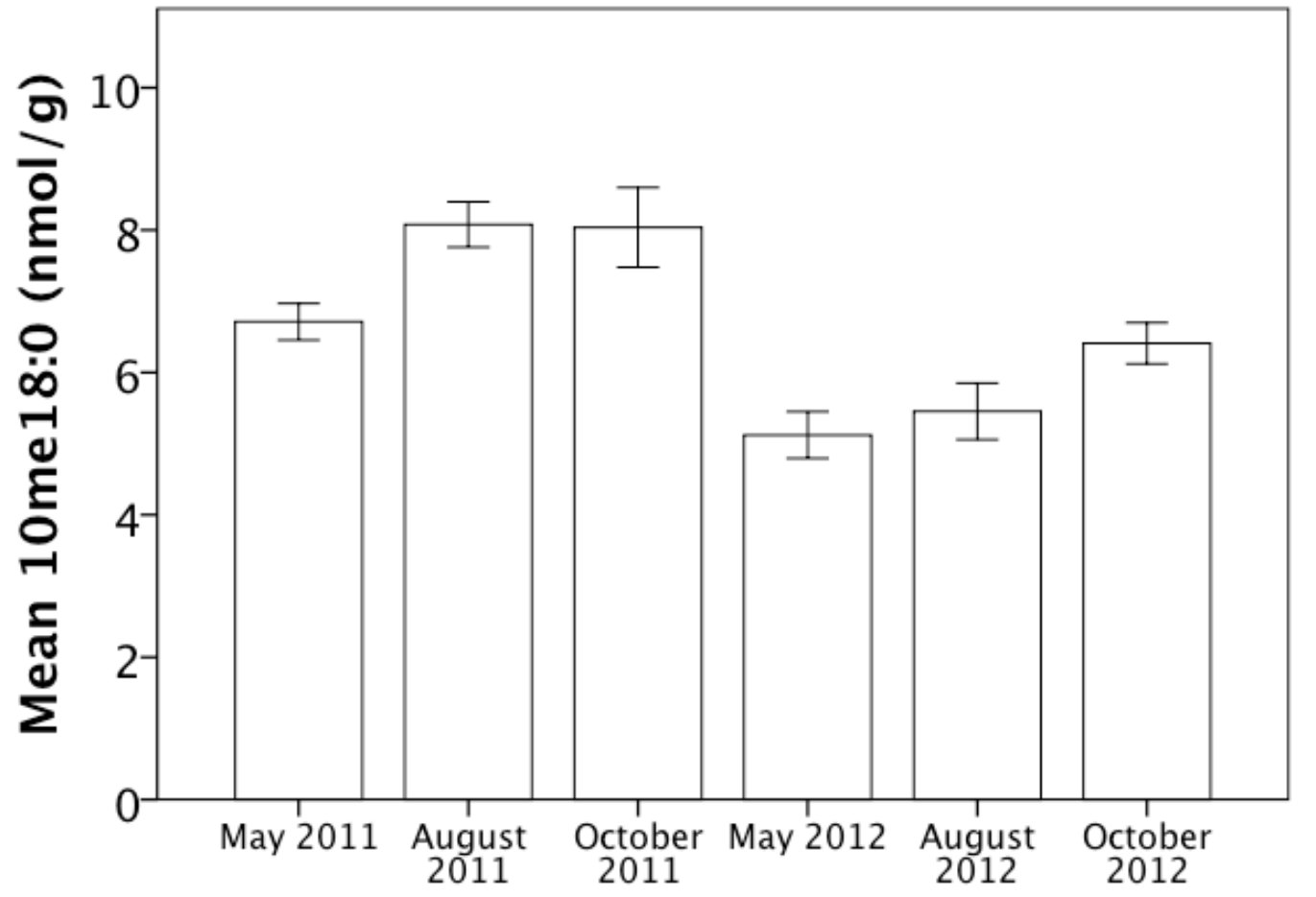

Figure 6.14 Mean actinomycete FAME 10me18:0 was significantly lower in 2012 versus 2011. Error bars are one standard error of the mean. 


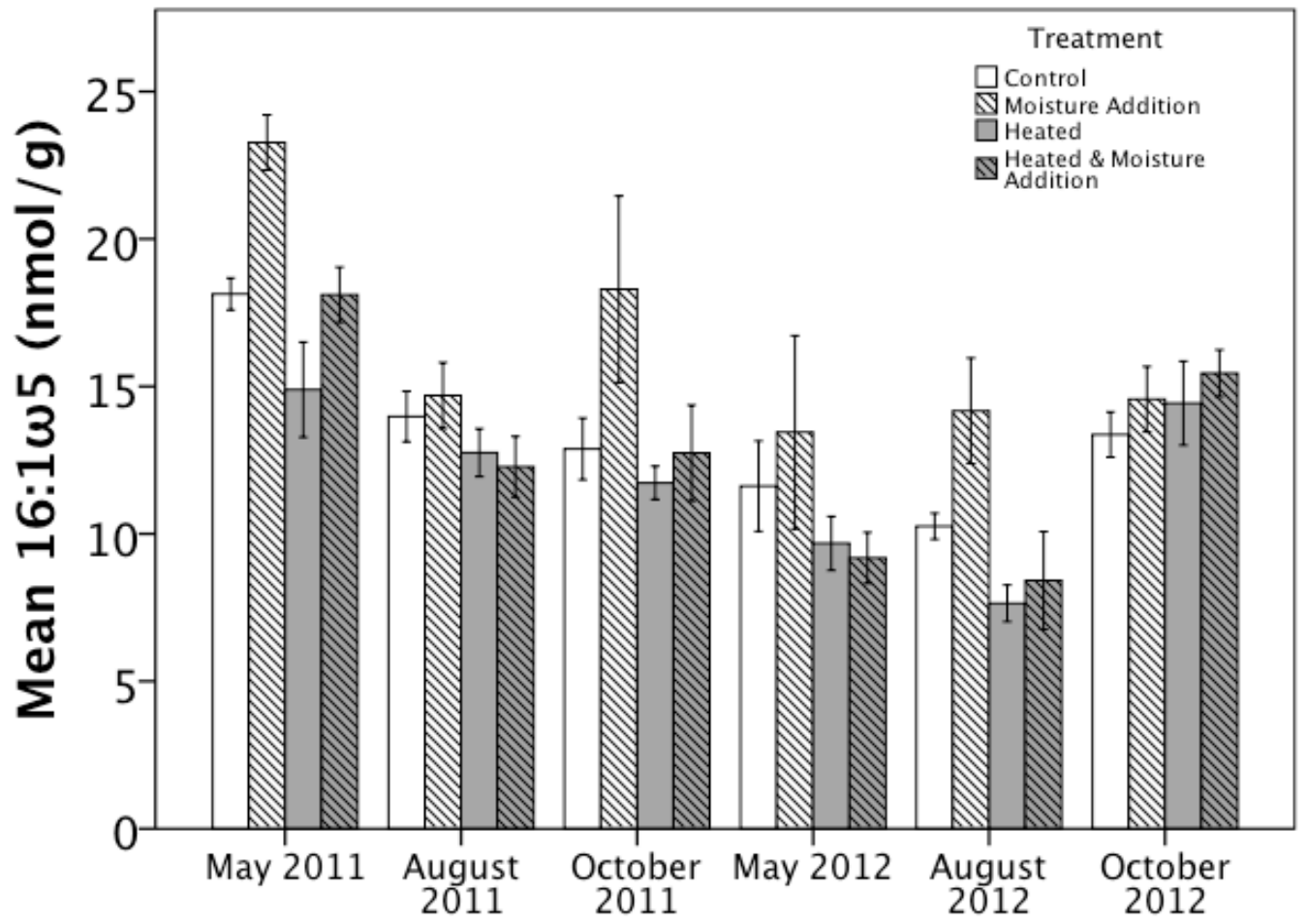

Figure 6.15 The mean arbuscular mycorrhizal fungal FAME 16:1 15 was significantly lower in heated versus unheated treatments, greater in moisture addition treatments versus treatments lacking moisture addition, and lower in combined heat and moisture addition treatments versus the control. The FAME content was greater in May 2011 and lower in May and August 2012 versus other months. Error bars are one standard error of the mean. 


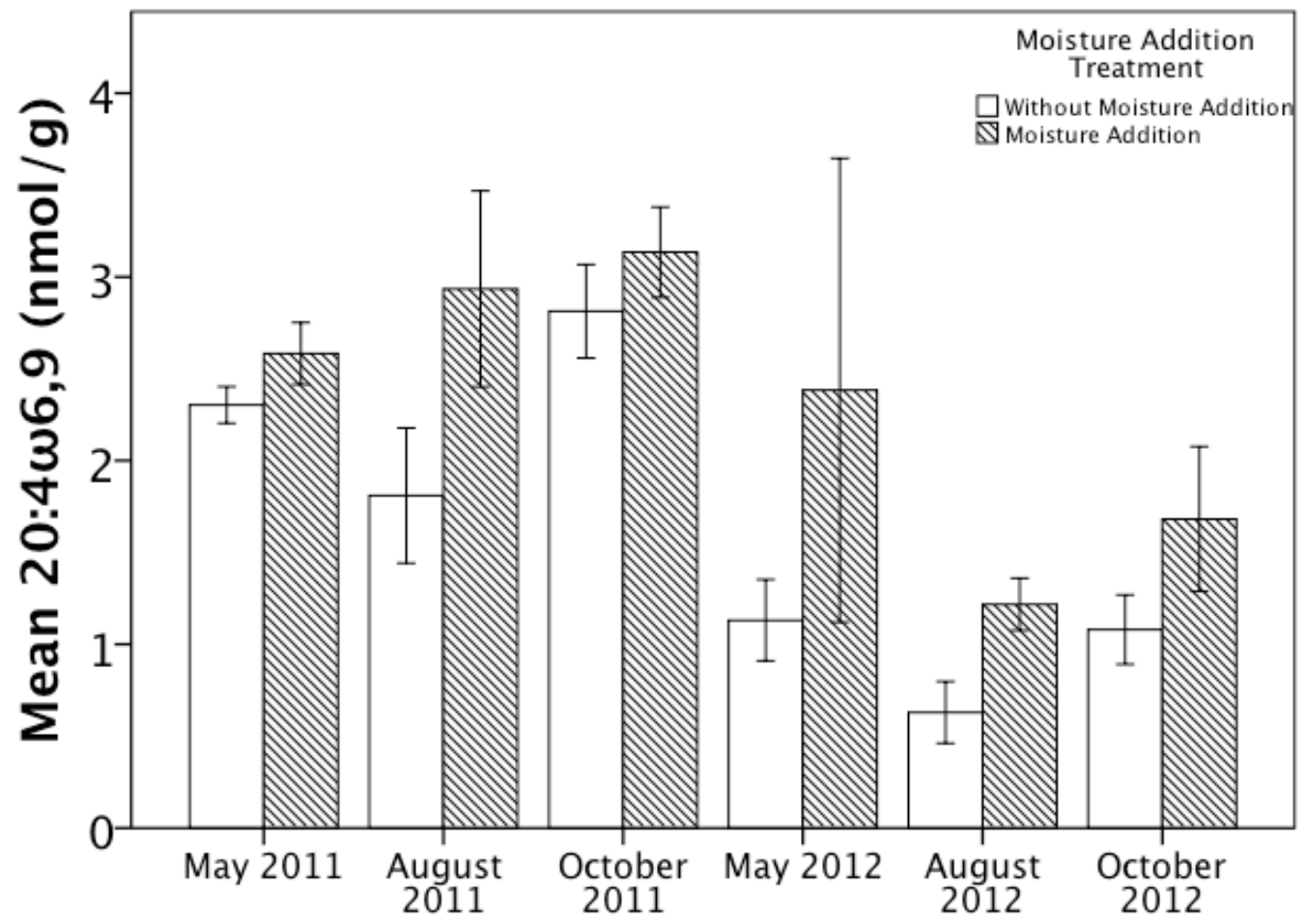

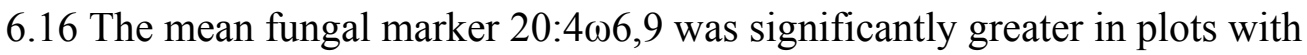
moisture addition versus plots without moisture addition. FAME content was lower in August 2012 versus other months and tended to be lower in 2012 versus 2011. Error bars are one standard error of the mean. 


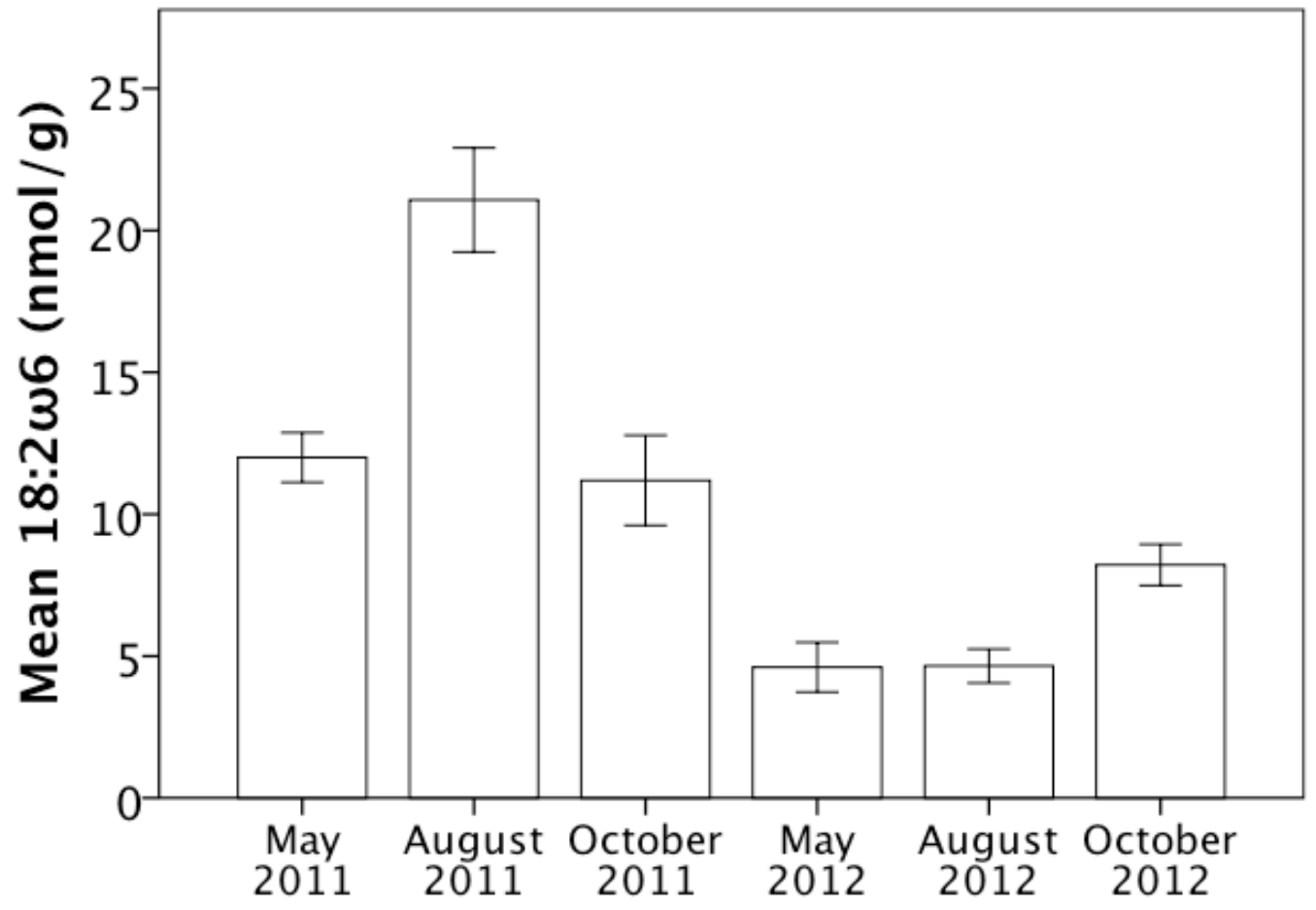

Figure 6.17 The mean fungal FAME 18:2 $\omega 6$ differed significantly by month. August 2011 had a significantly higher content than other months. May and August 2012 tended to have a lower FAME content versus other months. Error bars are one standard error of the mean. 


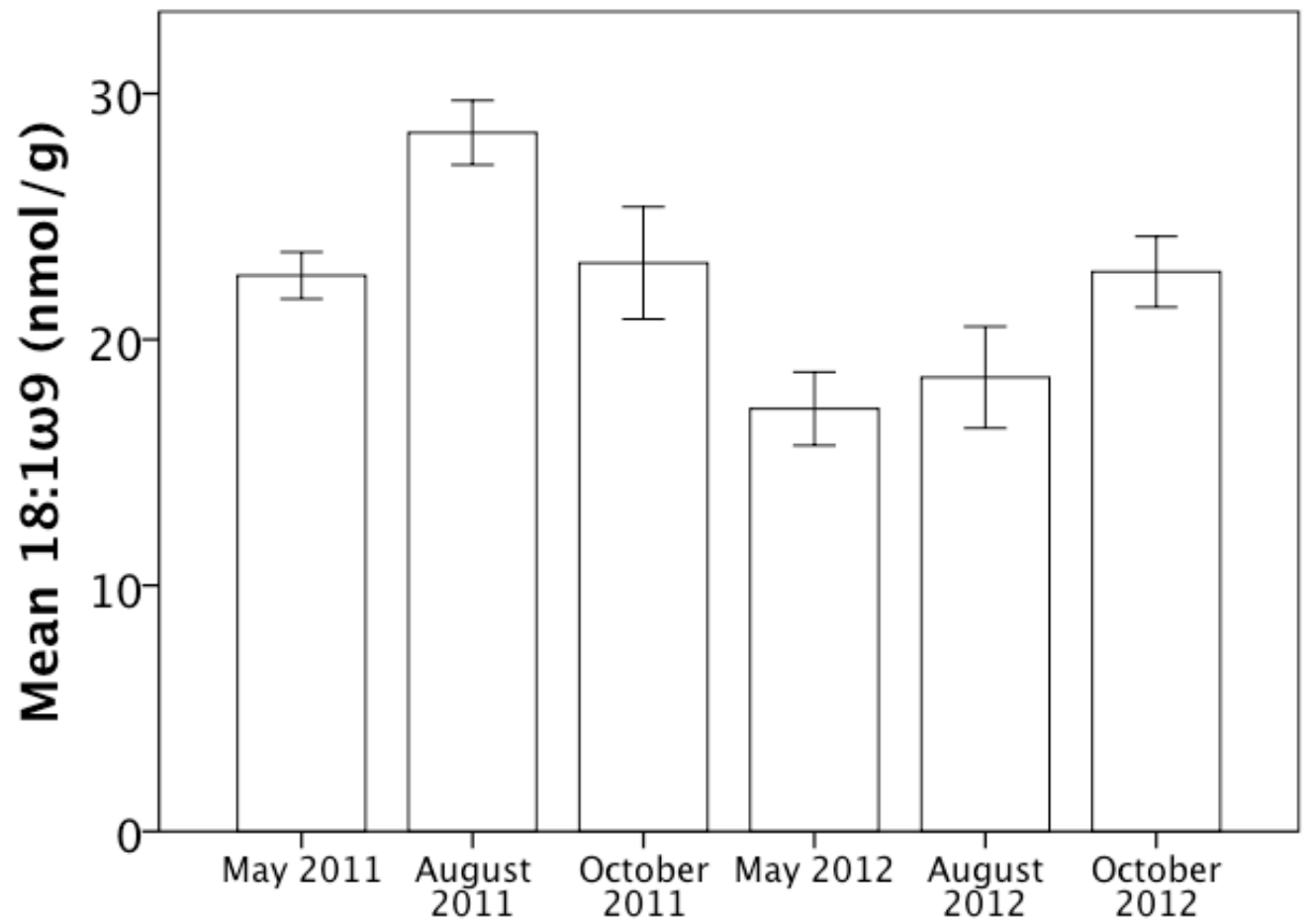

Figure 6.18 The mean fungal FAME 18:1 $\omega 9$ differed significantly by month. August 2011 had a significantly higher content than other months. May and August 2012 tended to have a lower FAME content versus other months. Error bars are one standard error of the mean. 


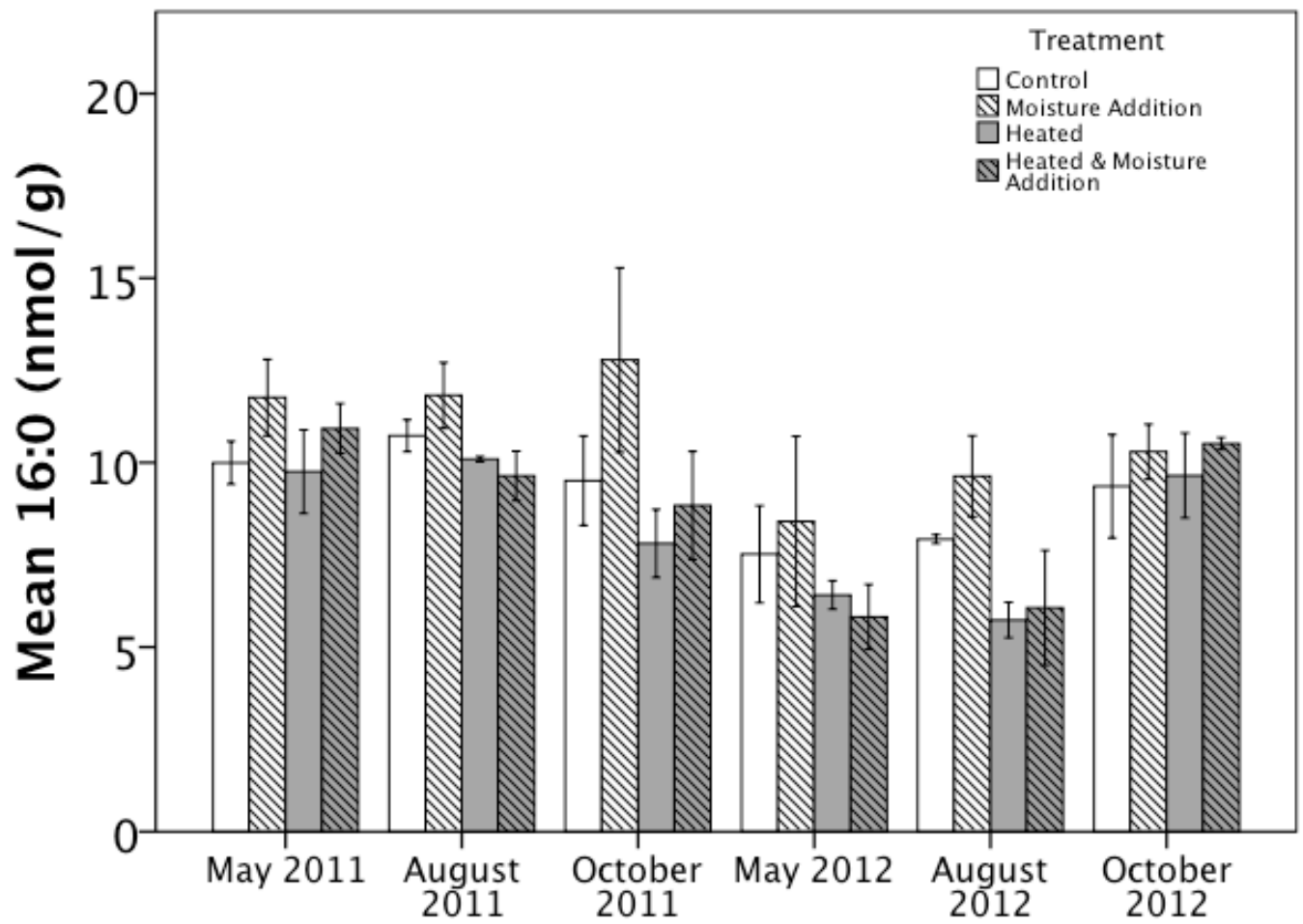

Figure 6.19 The total FAME marker 16:0 was significantly lower in heated versus unheated treatments and greater in plots receiving moisture addition versus those without moisture addition. FAME content was lower in May and August 2012 versus other months. Error bars are one standard error of the mean. 


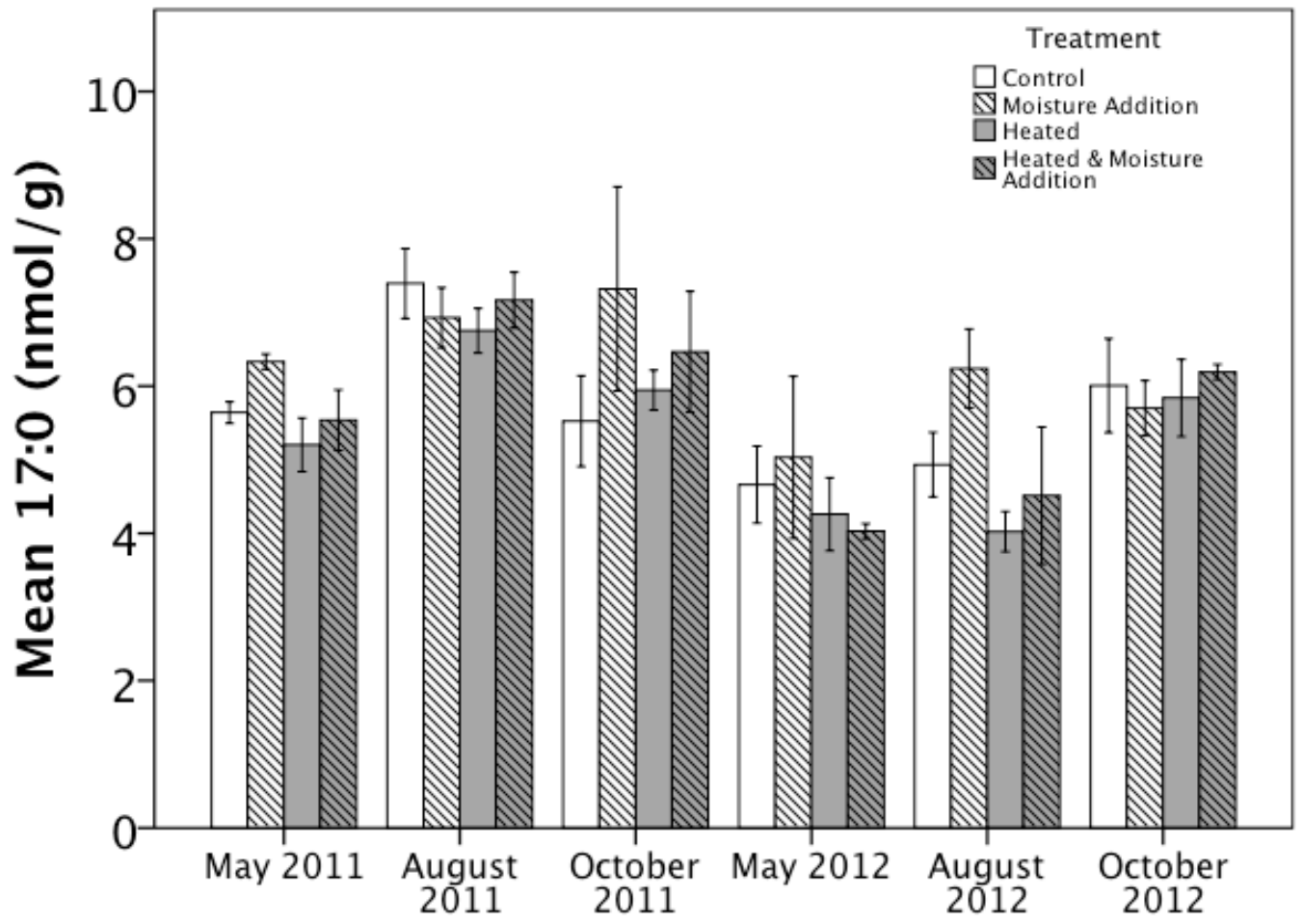

Figure 6.20 The total FAME marker 17:0 was significantly lower in heated versus unheated treatments and greater in plots receiving moisture addition versus those without moisture addition. FAME content was lower in May and August 2012 versus other months. Error bars are one standard error of the mean. 


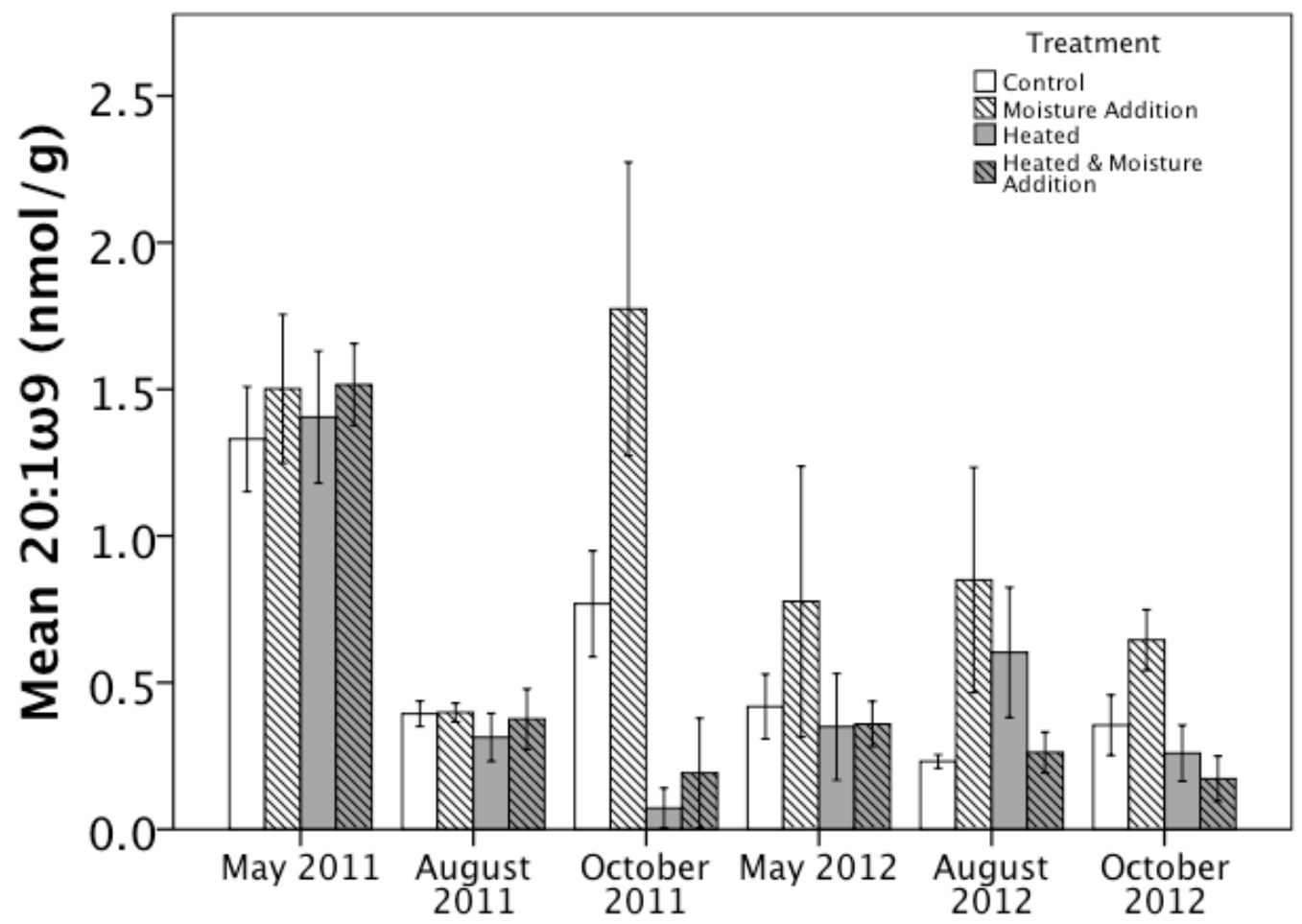

Figure 6.21 The total FAME marker 20:1 $\omega 9$ was significantly lower in heated versus unheated treatments, greater in plots receiving moisture addition versus those without moisture addition, and lower in the combined heat and moisture addition treatment versus the control. FAME content was significantly greater in May 2011 compared to other months. There was also a significant interaction between month and heat treatment. Error bars are one standard error of the mean. 


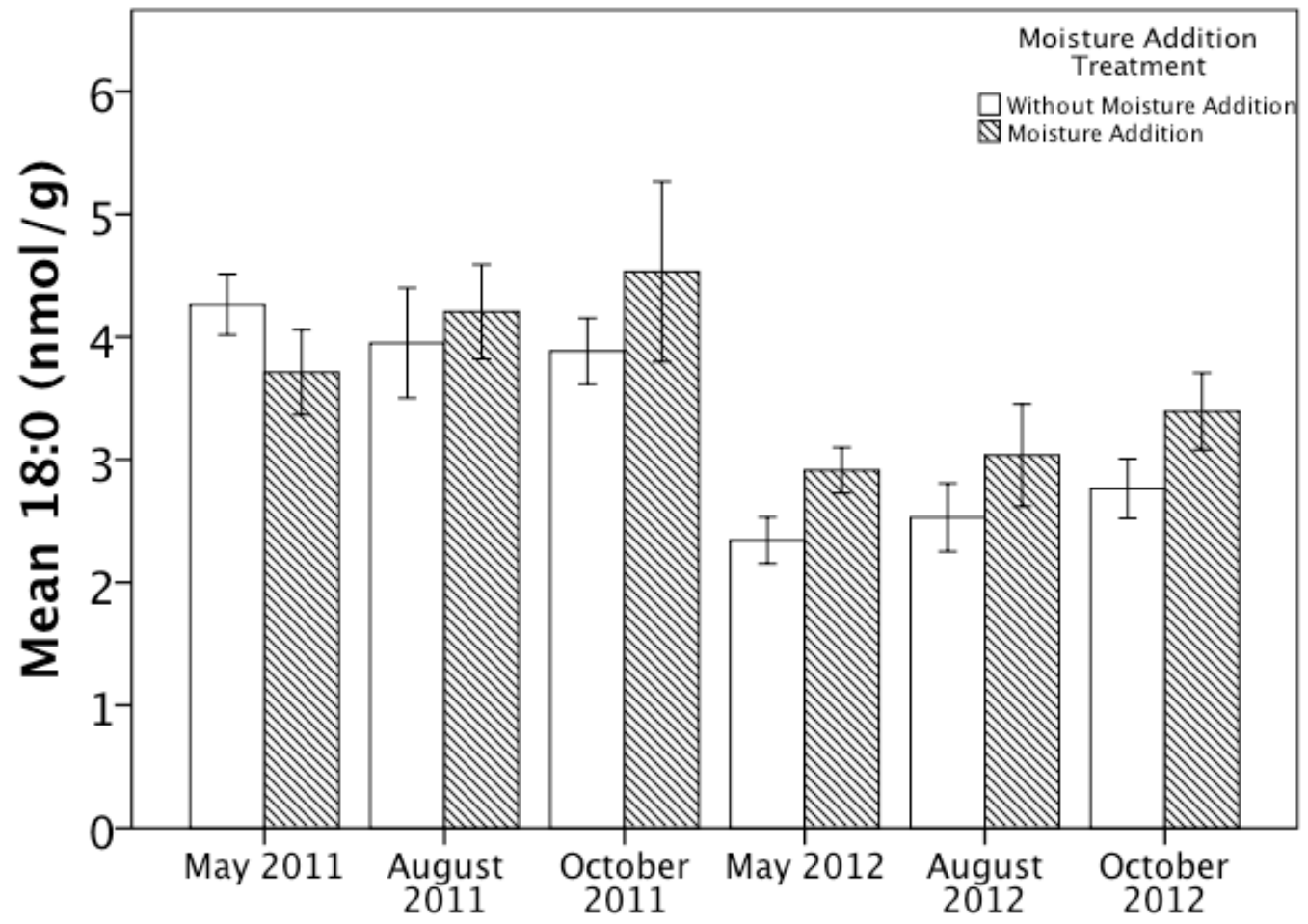

Figure 6.22 The total FAME marker 18:0 was significantly greater in moisture addition treatments versus treatments lacking moisture addition. FAME content was lower in 2012 versus 2011. Error bars are one standard error of the mean. 


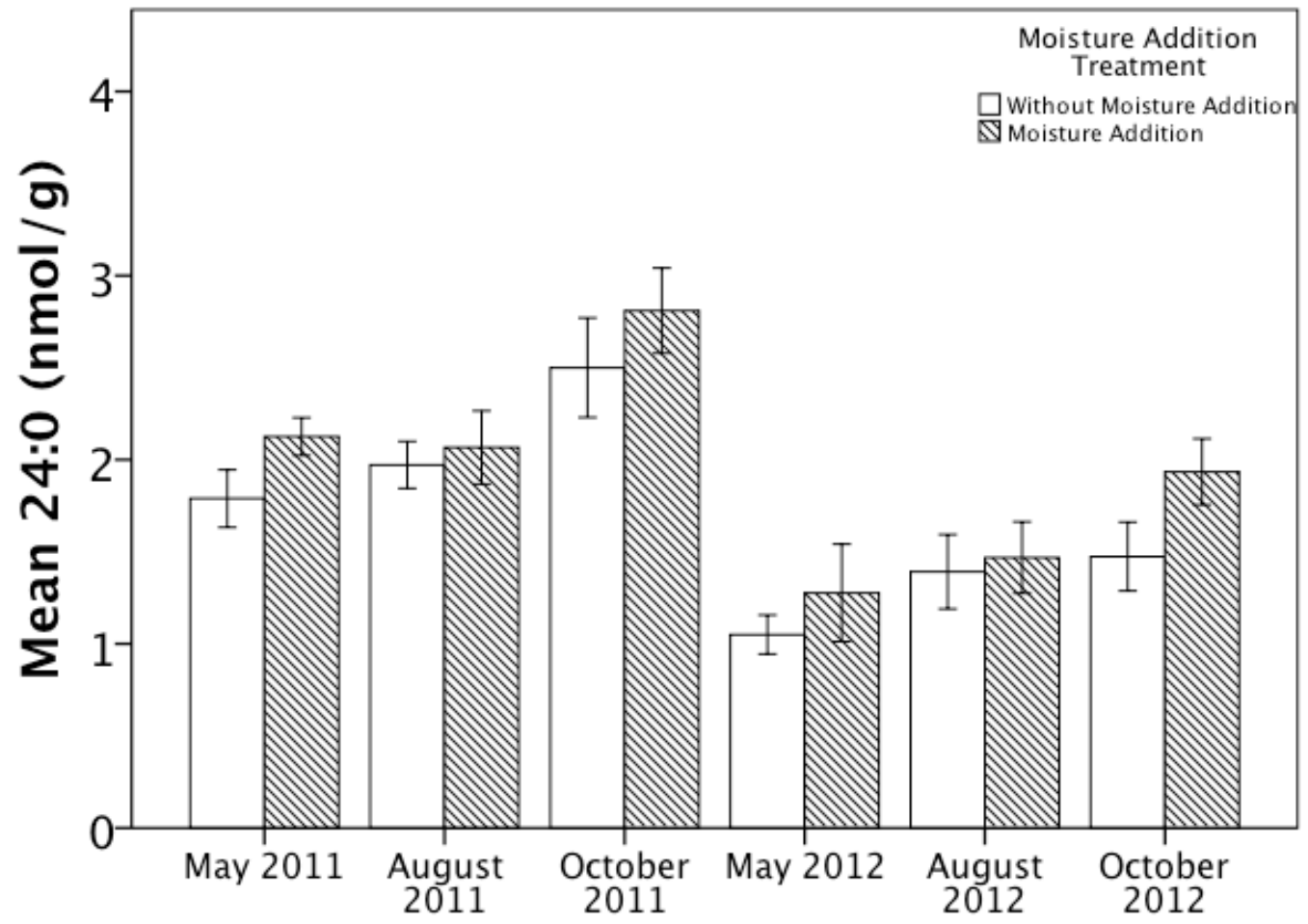

Figure 6.23 The total FAME marker 24:0 was significantly greater in moisture addition treatments versus treatments lacking moisture addition. FAME content was lower in 2012 versus 2011. Error bars are one standard error of the mean. 


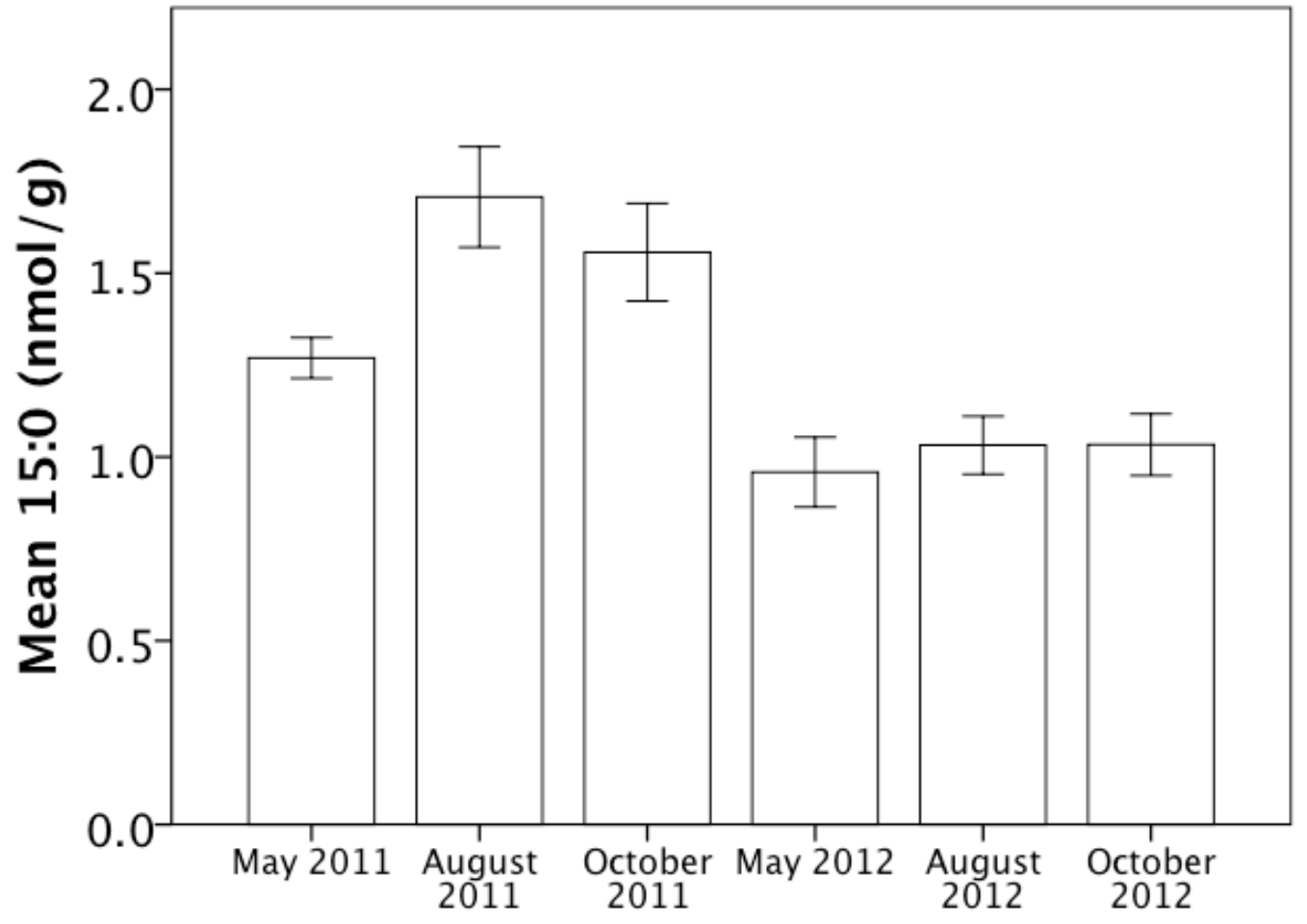

Figure 6.24 Mean total FAME marker 15:0 content varied significantly by month. Concentrations were greatest in August and October 2011 and lower in 2012 versus 2011. Error bars are one standard error of the mean. 


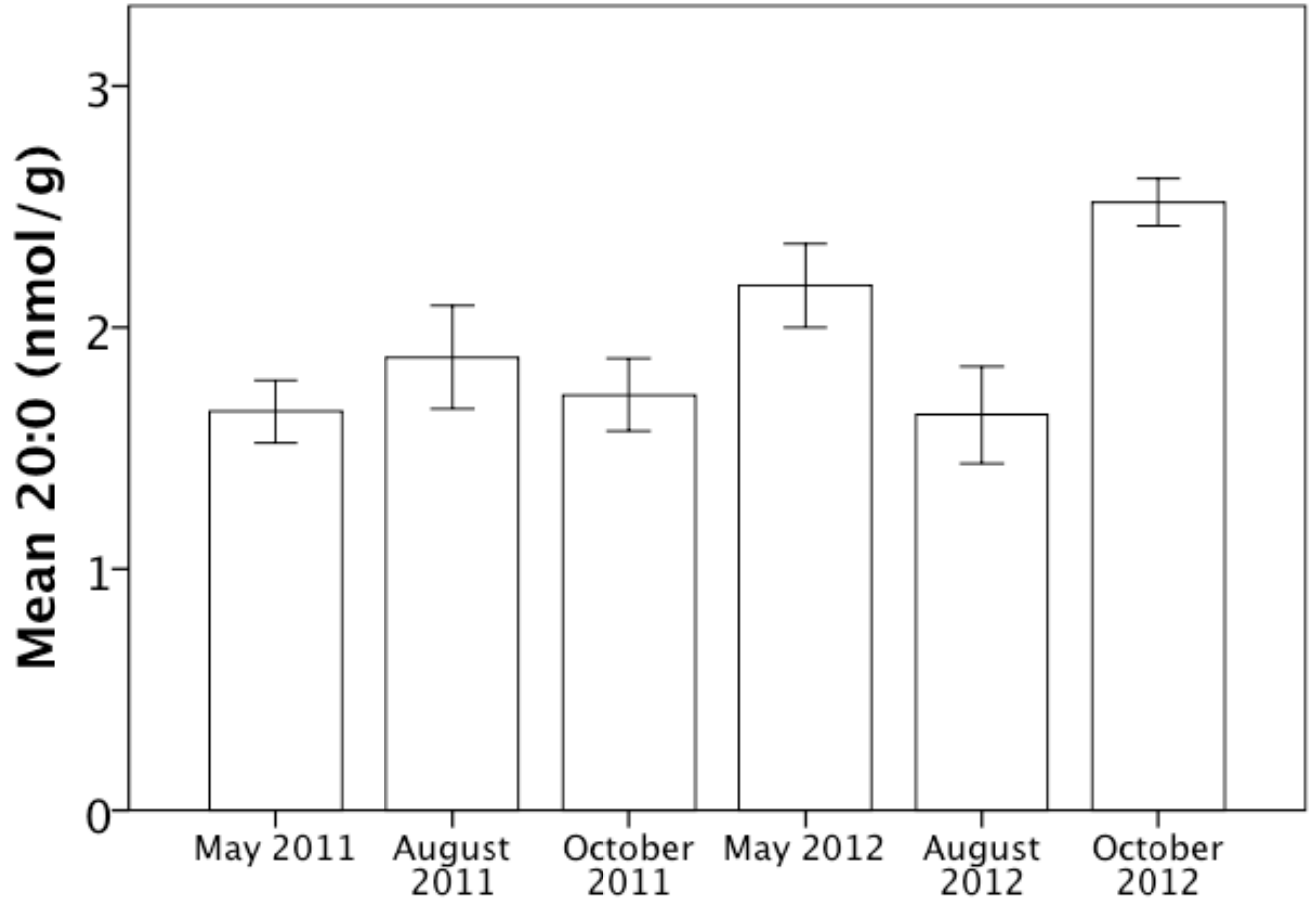

Figure 6.25 The mean total FAME 20:0 differed significantly by month. FAME content was greater in October 2012 versus other months. Error bars are one standard error of the mean. 


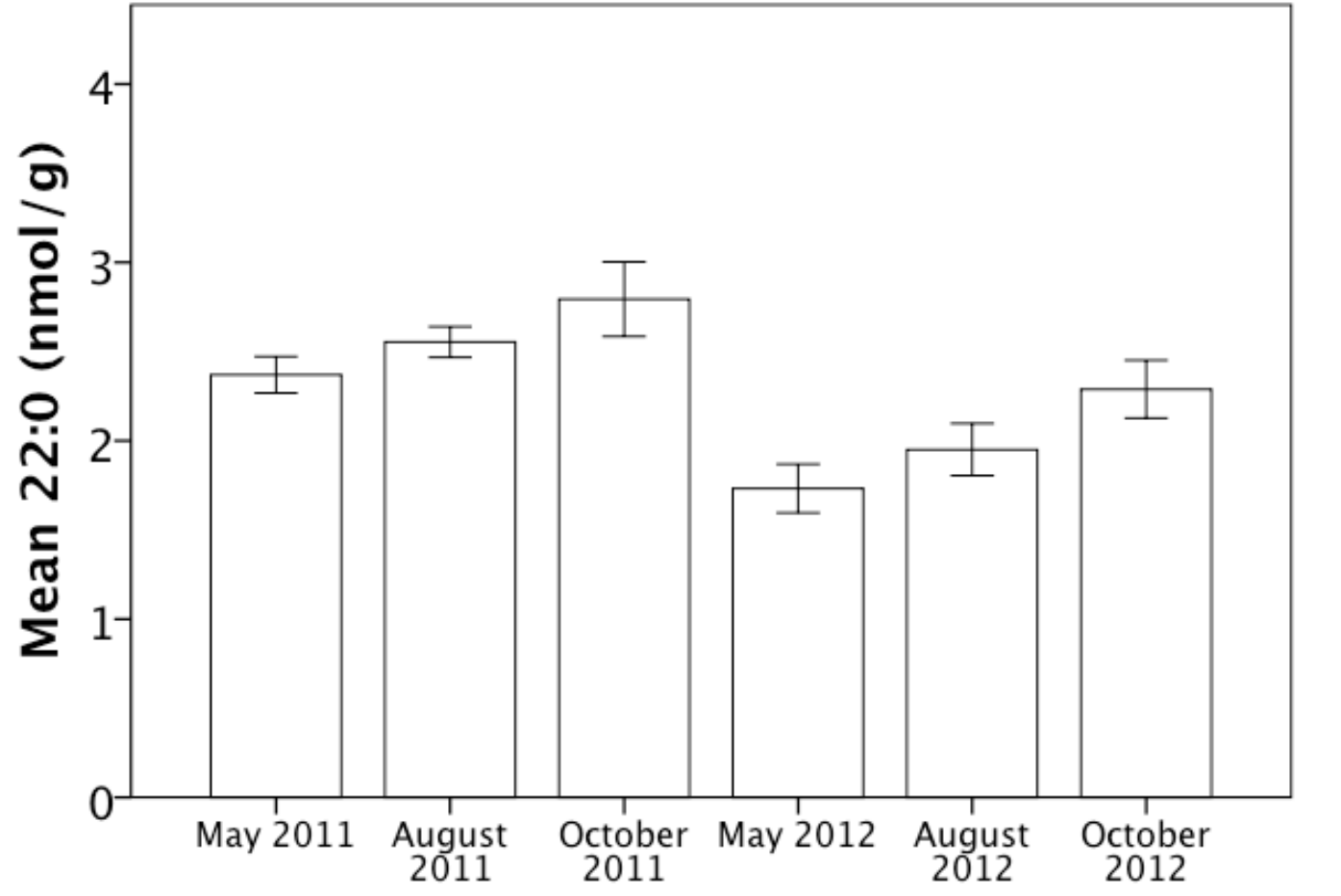

Figure 6.26 The total FAME 22:0 differed significantly by month. FAME concentrations were lower in 2012 versus 2011. Error bars are one standard error of the mean. 


\subsection{References}

Allison, S.D. 2005. Cheaters, diffusion and nutrients constrain decomposition by microbial enzymes in spatially structured environments. Ecology Letters. 8: 626-635.

Allison, S.D. and K.K. Treseder. 2008. Warming and drying suppress microbial activity and carbon cycling in boreal forest soils. Global Change Biology. 14: 2898-2909.

Bardgett, R.D., Freeman, C. and N.J. Ostle. 2008. Microbial contributions to climate change through carbon cycle feedbacks. ISME. 2: 805-814.

Björk, R.G., Björkman, M.P., Andersson, M.X. and L. Klemedtsson. 2008. Temporal variation in soil microbial communities in Alpine tundra. Soil Biology and Biochemistry. 40: 266-268.

Christensen, J. H., Hewitson, B., Busuioc, A. et al. In: Climate Change 2007: The Physical Science Basis. Contribution of Working Group I to the Fourth Assessment Report of the Intergovernmental Panel on Climate Change. Solomon, S. et al. (eds.). Cambridge University Press: New York, New York, USA

Briones, M.J.I, Ostle, N.J., McNamara, N.P. and J. Poskitt. 2009. Function shifts of grassland soil communitites in response to soil warming. Soil Biology \& Biochemistry. 41: 315-322.

Brockett, B.F.T., Presscott, C.E. and S.J. Grayston. 2012. Soil moisture is the major factor influencing microbial community structure and enzyme activities across seven biogeoclimatic zones in western Canada. Soil Biology \& Biochemistry 44: 920 .

Burton, A.J., Jarvey, J.C., Jarvi, M.P., Zak, D.R., and K.S. Pregitzer. 2012. Chronic $\mathrm{N}$ alters root respiration-tissue $\mathrm{N}$ relationship in northern hardwood forests. Global Change Biology. 18: 258-266.

Clemmensen, K.E., Michelsen, A., Jonasson, S. and G.R. Shaver. 2006. Increased ectomycorrhizal fungal abundance after long-term fertilization and warming of two arctic tundra ecosystems. New Phytologist. 171: 391-404. 
Frey, S.D., Drijber, R., Smith, H. and J. Melillo. 2008. Microbial biomass, functional capacity, and community structure after 12 years of soil warming. Soil Biology and Biochemistry. 40: 2904-2907.

Frostegård, A., Tunlid, A. and E. Bååth. 1991. Microbial biomass measured as total lipid phosphate in soils of different organic content. Journal of Microbiological Methods. 14: 151-163.

Jarvi, M.P. and A.J. Burton. 2013. Acclimation and soil moisture constrain sugar maple root respiration in experimentally warmed soil. Tree Physiology. 33: 949959.

Kellner, H., Vandenbol, M. and D. Zak. 2010. Fungi unearthed: Transcripts encoding lignocellulolytic and chitinolytic enzymes in forest soils. PLoS ONE. 5(6): e10971. doi:10.1371/journal.pone.0010971

Nannipieri, P., Ascher, J., Ceccherini, M.T., Landi, L., Pietramellara, G. and G. Renella. 2003. Microbial diversity and soil funcitons. European Journal of Soil Science. 54: 655-670.

Olsson, P.A., Bååth, E., Jakobsen, I. and B. Söderström. 1995. The use of phospholipid andneutral lipid fatty acids to estimate biomass of arbuscular mycorrhizal fungi insoil. Mycological Research. 99: 623-629.

Rinnan, R., Chelsen, A.M., Bååth, E. and S. Jonasson. 2007. Fifteen years of climate change manipulations alter soil microbial communities in a subarctic heath ecosystem. Global Change Biology. 13: 28-39.

Schindlbacher, A., Rodler, A., Kuffner, M., Kitzler, B., Sessitsch, A. and S. Zechmeister-Boltenstern. 2011. Experimental warming effects on the microbial community of a temperate mountain forest soil. Soil Biology \& Biochemistry. 43: 1417-1425.

Torsvik, V., and L. Øvreås. 2002. Microbial diversity and function in soil: from genes to ecosystems. Current Opinion in Microbiology. 5: 240-245.

Van Diepen, L. 2008. The role and diversity of arbuscular mycorrhizal fungi in Acer saccharum dominated forest ecosystems under natural and $\mathrm{N}$-amended conditions. Michigan Technological University, Ph.D. dissertation.

Wolf, D.M., Fontaine-Bodin, L., Bischofs, I., Price, G., Keasling, J. and A.P. Arkin. 2008. Memory in microbes: Quantifying history-dependent behavior in bacterium. PLoS ONE. 3(2): e1700. doi:10.1371/journal.pone.0001700. 
Zak, D.R., Pregitzer, K.S., Burton, A.J., Edwards, I.P. and H. Kellner. 2011. Microbial responses to a changing environment: Implications for the future functioning of terrestrial ecosystems. Fungal Ecology. dio:10.1016/j.funeco.2011.04.001. 


\section{Chapter 7: Conclusion}

Results from hyphal in-growth bag experiments conducted in Chapters 2 and 3 generally indicate that mycorrhizal fungi have lower growth and respiration at elevated temperatures. Chapter 2 presents results from Harvard Forest, a mixed northern hardwood forest in Massachusetts. Chapter 3 presents results from the Ford Forestry Center, a sugar maple dominated forest in northern Michigan. These two forest types differ in the type of mycorrhizal community present; Harvard Forest has mixed ectomycorrhizal fungi, and arbuscular mycorrhizal fungi dominate the Ford Forestry Center. The similar trends towards lower hyphal biomass production and respiration at the two sites suggests that different types of mycorrhizal fungi have similar responses to climate change conditions. There was a trend towards lower hyphal biomass production and respiration at Harvard Forest in heated plots, which are also much drier. Fungal growth and respiration at Harvard Forest were negative correlated with elevated temperature and positive correlated with moisture. At the Ford Forestry Center there was lower biomass production in the drought year of 2011 versus 2012. Both of these results indicate that mycorrhizal fungi may decline under dryer soil conditions. Increased drought frequency or intensity could have negative impacts on arbuscular mycorrhizae in these systems. Furthermore, nitrogen cycling is accelerated in heated versus unheated plots at both experimental sites (Mellilo et al. 2011 Butler et al. 2012, Jarvi and Burton 2013), and increased nitrogen availability may reduce the abundance of arbuscular mycorrhizal fungi (Van Diepen 2008). Warmer and dryer conditions could lead to a decline in mycorrhizal associations, which could permanently alter the carbon and nutrient cycling pathways in these forests. This reinforces the need for climate change studies that manipulate more than one environmental variable.

Results from Chapters 4 and 5 lend support to our hypothesis that soil warming would lead to higher potential enzyme activity at the experimental site in northern Michigan. Most of the enzymes assayed had higher potential activities at higher versus lower incubation temperatures. There was also evidence that soil 
moisture addition treatments increased the production of two hydrolytic enzymes and one oxidative enzyme in 2011. This may be a result of greater diffusion of soil nutrients or enzymes with higher soil moisture content. There was a drought during the 2011 growing season, and it is possible that elevated inputs of moisture to the soil increased enzyme production during the drought year in 2011 versus 2012. In accordance with this conjecture, acid phosphatase activity was much greater in 2011 versus 2012. This result may also be an artifact of changes in soil sampling and sorting methods between the two years. In 2011 soil samples were completely processed and enzyme assays were complete within 12 hours of soil collection, but in 2012 this process took 24 hours. Acid phosphatase activity tends to decrease as the time period between soil collection and laboratory enzyme assay incubation increases (DeForest 2009). All enzyme activity parameters showed significant seasonal variation. This is likely due to changes in the quality and quantity of soil organic matter, nutrients and moisture throughout the growing season, as well as changes in microbial abundance, microbial community structure, microbial demand and thermal adaptation and acclimation of the microbial community. Future research directed at understanding the specific chemical composition of carbon and nutrients in soils from experimental manipulations will aid in elucidating the mechanisms that drive enzymatic activity in soils under climate change conditions. Additionally, more studies focusing on microbial carbon use efficiency at various temperatures will produce data that can help to make soil carbon cycling models more precise (Frey et al. 2013). Understanding the relationship between the amount of carbon stored in microbial biomass and the amount of carbon actively processed by soil microorganisms will ultimately allow us to crack the "black-box" of the key processes that control soil respiration.

Chapter 6 examined the structure of the soil microbial community over two seasons of experimental manipulation at the Ford Forestry Center using phospholipid fatty acid (PLFA) analysis. In general, both fungal and bacterial PLFA markers were lower in heated versus unheated plots, and greater in plots with moisture addition compared to plots lacking moisture addition. Contrary to our hypotheses, the 
combined warming and moisture addition treatment tended to have lower PLFA content compared to the control treatment. This suggests that microbial biomass may decline under climate change conditions in these ecosystems. Future testing should investigate possible changes in the structure of the microbial community at a finer scale using metagenomic methods to survey active microorganisms in soils from the climate change manipulation studies. As we gain this knowledge, it will become increasingly important to understand how genomic and transcriptomic information relates to carbon and nutrient cycling in soils.

Microbial biomass was measured in two different ways at the study site in northern Michigan. Chloroform fumigation extractions were used in Chapter 5 to obtain estimates of microbial biomass $\mathrm{C}$ and $\mathrm{N}$, and PLFA analyses were used in Chapter 6. These two methods measure different components of microbial cells, although both are frequently used to estimate microbial biomass. Chloroform fumigation extractions measure all $\mathrm{C}$ and $\mathrm{N}$ contained in microbial cells, and PLFA analyses measure the $\mathrm{C}$ stored in microbial cellular membranes. The amount of $\mathrm{C}$ stored in microbial cellular membranes may change if there is a shift in the microbial community and the average surface area to volume ratio of microbial cells in the soil is altered. Although these two methods measure different components of microbial biomass, a linear regression between total PLFA content and microbial biomass $\mathrm{C}$ has marginal statistical significance (Figure 7.1). The two methods do not result in similar conclusions regarding the impact of soil warming and moisture addition on microbial biomass $\mathrm{C}$. The results of the chloroform fumigation extractions presented in Chapter 5 indicate that microbial biomass $\mathrm{C}$ and $\mathrm{N}$ did not differ between experimental treatments. Results of the PLFA analyses suggest that microbial biomass, measured as total PLFA content decreased in heated versus unheated plots and increased in moisture addition plots versus plots lacking moisture addition. This suggests that there may be a shift in the microbial community related to the experimental warming and moisture addition treatments. Understanding these potential shifts in the microbial community structure, and the relation to soil carbon 
and nutrient availability, will be paramount in making the connections needed to elucidate the connection between soil biology and geochemistry. 


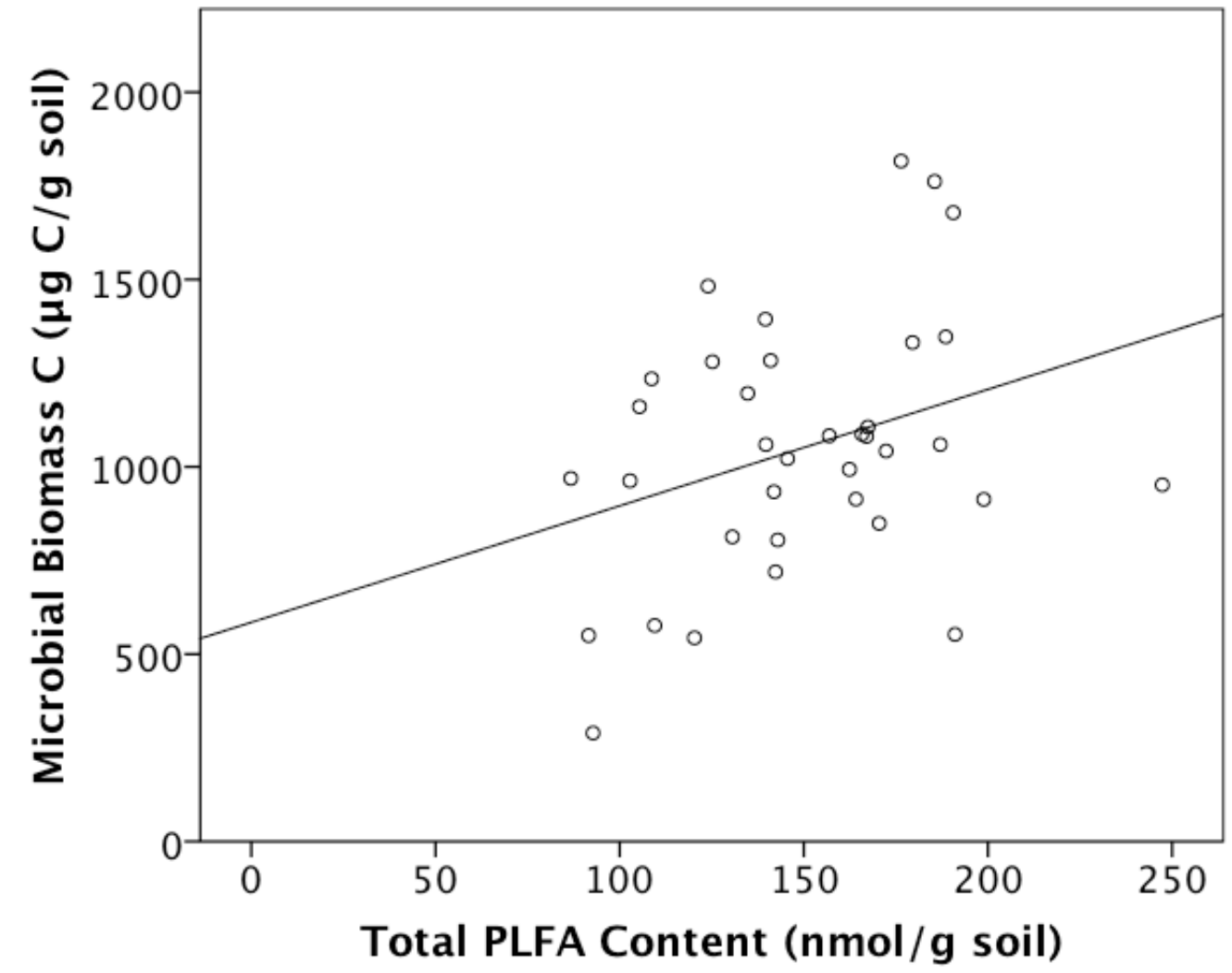

Figure 7.1 A linear regression between microbial biomass $\mathrm{C}$ and total PLFA content shows a marginally significant correlation. The equation for the line is Microbial Biomass $C=585+3.11$ (PLFA). The regression explains $10.6 \%$ of the variation $\left(\mathrm{F}_{1,34}=4.004, P=0.052\right)$. 


\section{References}

Butler, S.M., Melillo, J.M., Johnson, J.E., Mohan, J., Steudler, P.A., Lux, H., Burrows, E., Smith, R.M., Vario, C.L., Scott, L., Hill, T.D., Aponte, N. and F. Bowles. 2012. Soil warming alters nitrogen cycling in a New England forest: implications for ecosystem function and structure. Oecologia. 168: 819-828.

DeForest, J. 2009. The influence of time, storage temperature, and substrate age on potential soil enzyme activity in acidic forest soils using MUB-linked substrates and L-DOPA. Soil Biology and Biochemistry. 41: 1180-1186.

Frey, S.D., Lee, J., Melillo, J.M. and J. Six. 2013. The temperature response of soil microbial efficiency and its feedback to climate change. Nature Climate Change Letters. doi;10.1038/NCLIMATE1796.

Jarvi, M.P. and A.J. Burton. 2013. Acclimation and soil moisture constrain sugar maple root respiration in experimentally warmed soil. Tree Physiology. 33: 949959.

Melillo, J., Butler, S., Johnson, J., Mohan, J., Steudler, P., Lux, H., Burrows, E., Bowles, F., Smith, R., Scott, L., Vario, C., Hill, T., Burton, A., Zhou, Y. and J. Tang. 2011. Soil warming, carbon-nitrogen interactions, and forest carbon budgets. PNAS. 8(23): 9508-9512.

Van Diepen, L. 2008. The role and diversity of arbuscular mycorrhizal fungi in Acer saccharum dominated forest ecosystems under natural and $\mathrm{N}$-amended conditions. Michigan Technological University, Ph.D. dissertation. 